\title{
RÁKellenes ÉS AlZHEIMER-Kórban AlKalmazHATó LIGANDUMOK ÉS FÉMKOMPLEXEINEK OLDATKÉMIÁJA
}

Doktori (Ph.D.) értekezés

\author{
SIJA ÉVA Ilona
}

Témavezetők:

Dr. KISS TAMÁS

TANSZÉKVEZETŐ EGYETEMI TANÁR

DR. ENYEDY ÉVA ANNA

EGYETEMI ADJUNKTUS

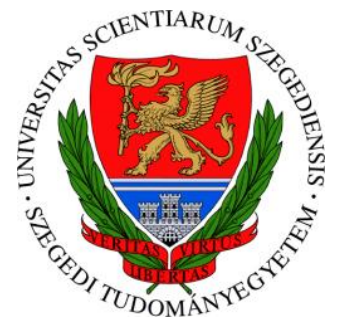

Kémia Doktori Iskola

MTA-SZTE Bioszervetlen Kémiai Kutatócsoport

Szervetlen és Analitikai Kémiai Tanszék

Természettudományi és Informatikai Kar

Szegedi Tudományegyetem

Szeged, 2013 


\section{Tartalomjegyzék}

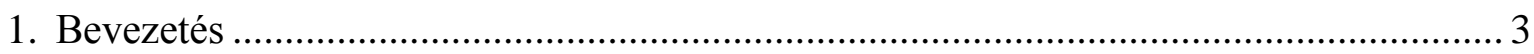

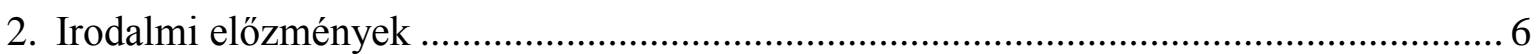

2.1. Fémionok szerepe, és kelátor molekulák alkalmazása a neurodegeneratív

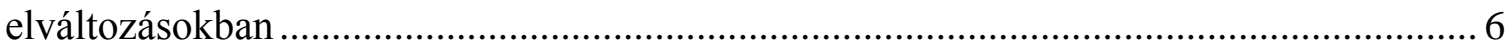

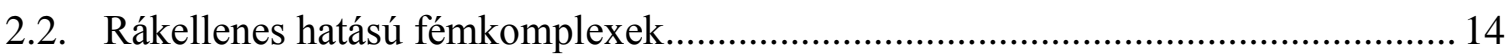

2.3. A speciáció alkalmazási lehetőségei a bioaktív fémvegyületek biológiájában ....... 24

3. Alkalmazott vizsgálati módszerek, kísérleti körülmények .......................................... 27

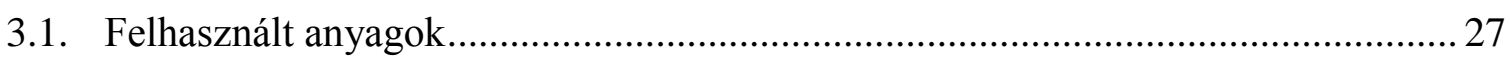

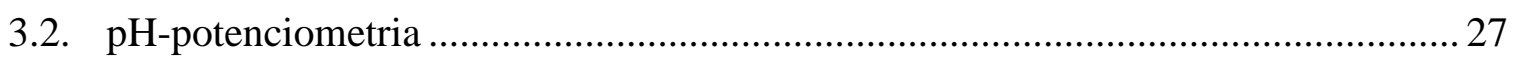

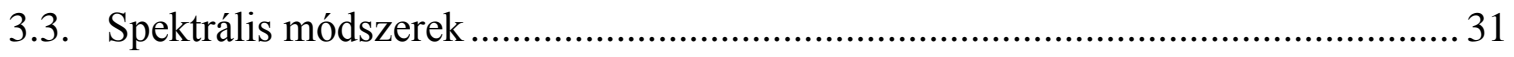

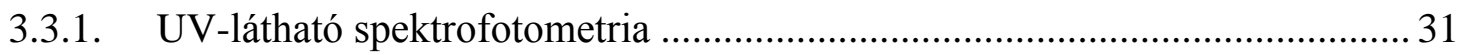

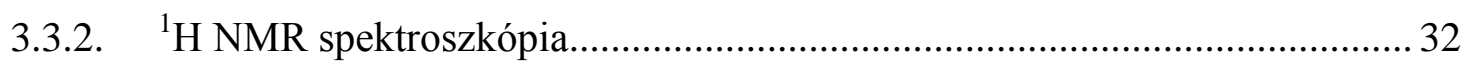

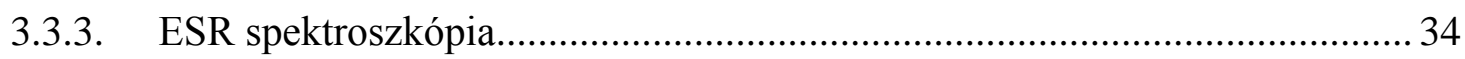

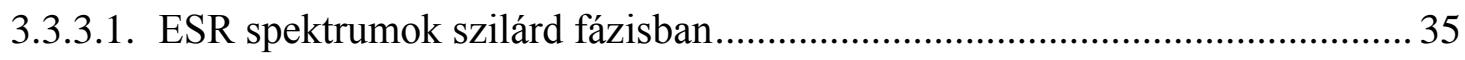

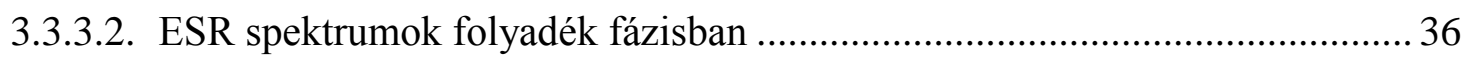

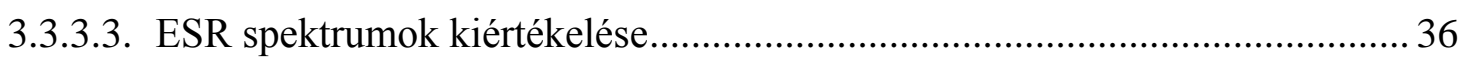

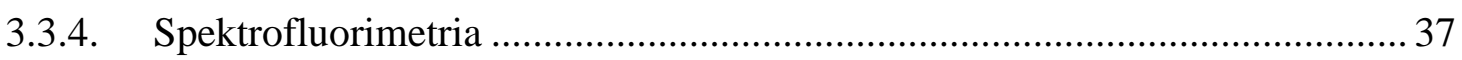

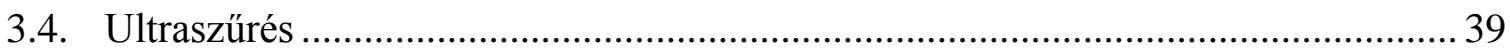

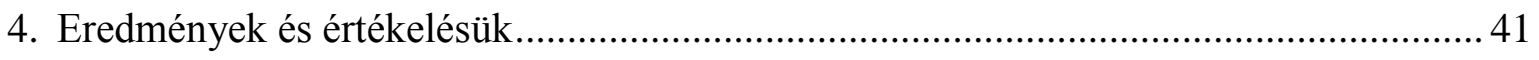

4.1. $\mathrm{A}\left[\mathrm{Ru}(\mathrm{II})-\eta^{6}-p\right.$-cimol] és a ligandumok bemutatása és sav-bázis sajátságaik ......... 41

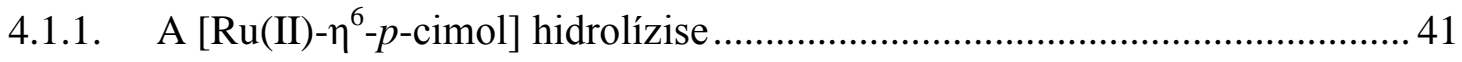

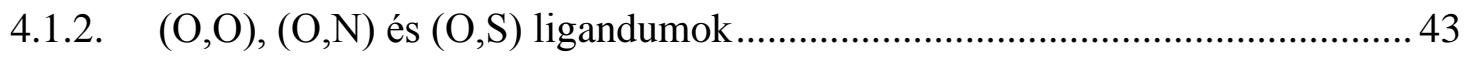

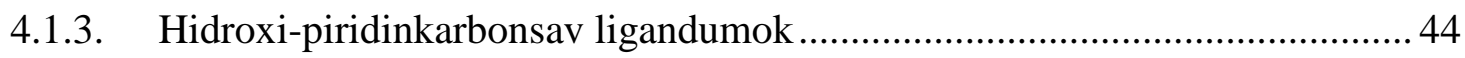

4.2. Hidroxi-piridinkarbonsavak, mint fémion kelátorok a neurodegeneratív

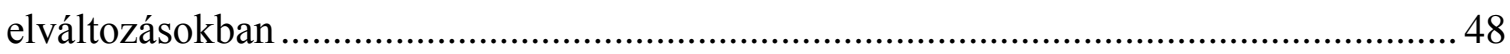

4.2.1. Komplexképződés három vegyértékü (Fe(III) és $\mathrm{Al}(\mathrm{III}))$ fémionokkal......... 48

4.2.2. Komplexképződés két vegyértékü $(\mathrm{Cu}(\mathrm{II})$ és $\mathrm{Zn}(\mathrm{II}))$ fémionokkal ...............50 
4.2.3. Legfontosabb következtetések a hidroxi-piridinkarbonsavak komplexképző sajátságairól

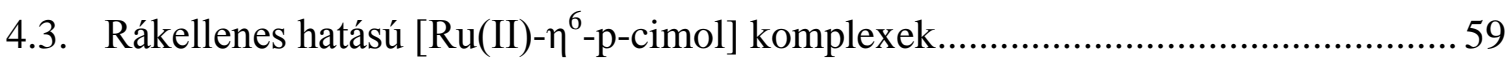

4.3.1. $\quad(\mathrm{O}, \mathrm{O})$ ligandumok oldategyensúlyi viszonyai $\left[\mathrm{Ru}(\mathrm{II})-\eta^{6}-p\right.$-cimol]-lal 59

4.3.1.1. [Ru(II)- $\eta^{6}-p$-cimol]-etil-maltol rendszer tanulmányozása kloridmentes közegben

4.3.1.2. $\left[\mathrm{Ru}(\mathrm{II})-\eta^{6}\right.$-p-cimol]-etil-maltol és $\left[\mathrm{Ru}(\mathrm{II})-\eta^{6}\right.$-p-cimol]-allomaltol rendszer tanulmányozása kloridiont tartalmazó közegben

4.3.2. $(\mathrm{O}, \mathrm{N})$ ligandumok oldategyensúlyi viszonyai $\left[\mathrm{Ru}(\mathrm{II})-\eta^{6}-p\right.$-cimol]-lal 65

4.3.2.1. [Ru(II)- $\eta^{6}$-p-cimol]-pikolinsav rendszer tanulmányozása kloridmentes közegben

4.3.2.2. [Ru(II)- $\eta^{6}$-p-cimol] komplexképződési folyamatai pikolinsav, 6-metil-pikolinsav és 2,6-dipikolinsav ligandumokkal kloridionos közegben. 69

4.3.3. $(\mathrm{O}, \mathrm{S})$ ligandumok oldategyensúlyi viszonyai $\left[\mathrm{Ru}(\mathrm{II})-\eta^{6}-\mathrm{p}-\mathrm{cimol}\right]-\mathrm{lal}$ .78

4.3.3.1. [Ru(II)- $\eta^{6}-p$-cimol]-tioallomaltol rendszer tanulmányozása kloridiont tartalmazó közegben

4.3.4. Legfontosabb következtetések [Ru(II)- $\eta^{6}-p$-cimol] komplexek oldategyensúlyáról

4.4. Hidroxi-piridinkarbonsavak és [Ru(II)- $\eta^{6}$ - $p$-cimol] komplexek kölcsönhatása humán szérum albuminnal

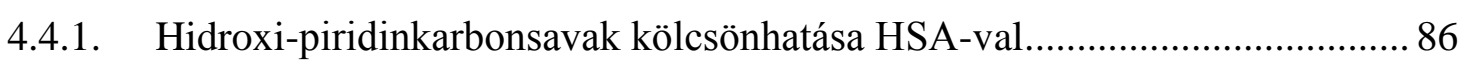

4.4.2. [Ru(II)- $\eta^{6}-p$-cimol], [Ru(II)- $\eta^{6}-p$-cimol]-pikolinát és [Ru(II)- $\eta^{6}-p$-cimol $]$-etil-

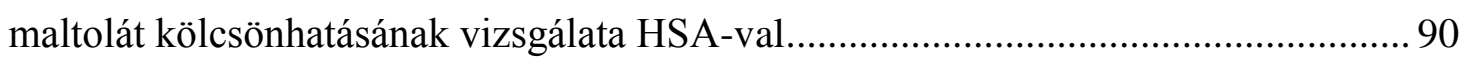

5. Összefoglalás .92

6. Summary .96

7. Mellékletek 101

8. Felhasznált irodalom 103 


\section{Bevezetés}

A bioszervetlen kémia egy olyan interdiszciplináris tudományterület, mely a fémionok és fémkomplexek biológiai hatásaival foglalkozik élő rendszerekben. A fémionok és ezek biomolekulákkal alkotott komplexei az egész élővilágban és a különböző életfolyamatok minden szintjén fontos szerepet játszanak. Elég, ha a növények fotoszintézisében szerepet játszó $\mathrm{Mg}(\mathrm{II})$ tartalmú klorofill molekulára, vagy a gerinces állatok oxigénszállításában fontos hemoglobin molekulára gondolunk. Számos fémion alapvető fontosságú az enzimek felépítésében és megfelelő müködésében. Világszerte jelentős kutatási erőfeszítések történnek, hogy jobban megérthessük a fémionok biológiai funkcióját az élö szervezetben, vagy épp a betegségek kialakulásában betöltött szerepüket. Így a bioszervetlen kémia jelentősen hozzájárult az orvostudományhoz is, sőt, azt mondhatjuk, hogy kibontakozásával párhuzamosan fejlődött ki az úgynevezett orvosi vagy gyógyszerészeti szervetlen kémia (medicinal inorganic chemistry), melynek felfedezései jelentős hatással vannak a modern klinikai orvostudományra. Az elmúlt pár évtizedben számtalan fémkomplexet fejlesztettek ki terápiás vagy diagnosztikai céllal. Befolyásolni tudják a szervezet fémionhomeosztázisát (azaz a fémion háztartás belső egyenyúlyát): hiánybetegség esetén számos létfontosságú fémion hatékonyabban pótolható komplex vegyület formájában, vagy épp ellenkezőleg, a szervezetben fellépő fémionfelesleg, vagy toxikus fémionok eltávolítására alkalmaznak kelátképző ligandumokat. Bár még napjainkban is a gyógyszeripar nagy részét a szerves kémia uralja, és alulértékelik a fémtartalmú gyógyszerek szerepét, számos áttörő sikert értek el velük a gyógyászatban. Úttörő sikert jelentett a ciszplatin (cisz[Pt $\left.\left(\mathrm{NH}_{3}\right)_{2} \mathrm{Cl}_{2}\right)$ sejtosztódást gátló, rákellenes aktivitásának felfedezése (Rosenberg - 1964), mely után számos kutatócsoport figyelme fordult a fémtartalmú terápiás szerek felé. Bár a ciszplatin ma is forgalomban van, hátrányos tulajdonságai miatt (kis szelektivitás, mellékhatások és rezisztencia kialakulása) számtalan más platina, és egyéb fémiontartalmú komplex kifejlesztésére történtek és történnek ma is próbálkozások biztató eredményekkel. Ígéretes kutatások folynak ruténium(III)tartalmú komplexekkel, melyek tesztelései már klinikai fázisba léptek. Potenciális rákellenes kemoterápiás szerként tartják számon a ruténium(II) félszendvics szerkezetü fémkomplexeit is, melyekben a fémiont egy arén vegyület védi az oxidációtól. A Ph.D. munkámban fontos szerepet betöltő $\left[\mathrm{Ru}(\mathrm{II})-\eta^{6}-p-\right.$ cimol] molekulának önmagában nincs különösebb rákellenes hatása, azonban a citotoxikus aktivitása megfelelő ligandumok koordinálódása révén jelentősen javítható. A komplexek hatásmechaniz-musának, biotranszformációjának megértéséhez elengedhetetlen az 
egyensúlyi kémiájuk felderítése. Munkánk során célul tüztük ki, hogy meghatározzuk kétfogú, $(\mathrm{O}, \mathrm{O}),(\mathrm{O}, \mathrm{N})$ és $(\mathrm{O}, \mathrm{S})$ donoratomos ligandumok $\left[\mathrm{Ru}(\mathrm{II})-\eta^{6}-p\right.$-cimol] komplexeinek összetételét, stabilitási állandóit, és ezen keresztül a rendszerek részecskeeloszlásait pH-potenciometriás, UV-látható spektrofotometriás és ${ }^{1} \mathrm{H}$ NMR spektroszkópiás módszerek segítségével. A vizsgált $\left[\mathrm{Ru}(\mathrm{II})-\eta^{6}-p-\operatorname{cimol}(\mathrm{OX}) \mathrm{Z}\right]\left(\mathrm{X}=\mathrm{O}, \mathrm{N}\right.$, vagy $\mathrm{S} ; \mathrm{Z}=\mathrm{H}_{2} \mathrm{O}$ vagy $\mathrm{Cl}^{-}$) típusú komplexek vizes oldatbeli speciációs vizsgálatai alapján az alábbi stabilitás trendet állapítottuk meg: $(\mathrm{O}, \mathrm{S})>>(\mathrm{O}, \mathrm{N})>(\mathrm{O}, \mathrm{O})$, mely trend erősen korrelál a komplexek különböző rákos sejtvonalon mért biológiai aktivitásával. Vizsgálataimhoz a $\left[\mathrm{Ru}(\mathrm{II})-\eta^{6}-p\right.$-cimol $]$ komplexet $\left[\mathrm{Ru}(\mathrm{II})_{2}\left(\eta^{6}-p \text {-cimol }\right)_{2} \mathrm{Cl}_{2}\right] \mathrm{Cl}_{2}$ dimer formájában a Bécsi Egyetem Szervetlen Kémiai Intézete biztosította.

Ph.D. munkám másik fő területe szintén nemzetközi együttmüködés keretében valósult meg. A Padovai Egyetem Kémiai Tudományok Tanszékével közös munkában a cél olyan kelátor típusú molekulák kifejlesztése és vizsgálata, melyek képesek lennének befolyásolni és helyreállítani a neurodegenerációs folyamatokban felelőssé tehető fémion-homeosztázis felborulását, képesek versenyezni a $\beta$-amiloid fehérjékkel a fémionokért, így megakadályozhatják a toxikus oligomer formák, majd aggregátumok keletkezését, mely a kórra jellemző plakképződést okozza az Alzheimer-kóros betegek agyában. Irodalmi adatok szerint ugyanis számos kapcsolat figyelhető meg a fémion háztartás megváltozása és az Alzheimer-kór, illetve egyéb neurodegeneratív betegség kialakulása között. A kutatási munkám célpontjai hidroxi-piridinkarbonsav molekulák metilált származékainak Fe(III), $\mathrm{Al}(\mathrm{III}), \mathrm{Cu}(\mathrm{II})$ és $\mathrm{Zn}$ (II)ionokkal alkotott komplex vegyületek stabilitásának meghatározása volt, amely fémionok agyi ionháztartásának felborulása a szervezetben együtt járhat a neurodegeneratív betegségek szempontjából releváns amiloid fehérje aggregációjával, szerkezeti károsodásával és biológiai szerepének megváltozásával is. A képződő fémkomplexekben szalicilát típusú koordináció alakul ki. A gyürüben lévő nitrogénatom hatására a képződő fémkomplexek stabilitása nagyobb, mint a megfelelő szalicilsav komplexeké, ami metil-szubsztituensekkel tovább növelhető, azonban egyik esetben sem éri el a ma használt, és alkalmazásban lévő kelátor molekulák fémkomplexeinek stabilitását. Emellett részletesen vizsgáltuk a maguknak a ligandumoknak a sav-bázis tulajdonságát, hogy a korábbiakhoz képest teljesebb képet adjunk a ligandumok deprotonálódási folyamatairól.

Mivel feltehetően, a gyógyászati célra megfelelő és alkalmazásra kerülő fémkomplexek és ligandumok a véráramban szállítódnak kölcsönhatásuk különböző vérben lévő molekulákkal, elsősorban az albuminnal fontos lehet. Ezért a hidroxi-piridinkarbonsav 
ligandumok, a [Ru(II)- $\eta^{6}-p$-cimol] és néhány komplexének humán szérum albuminnal való kölcsönhatását ultraszürésessel és spektrofluorimetriás mérésekkel vizsgáltuk.

Értekezésem következő, 2. fejezete röviden a fémionok szerepét foglalja össze a neurodegeneratív betegségekben (föként az Alzheimer-kórban) majd a rákos megbetege-dések és rákellenes hatású fémkomplexek irodalmát tekinti át röviden. Az alkalmazott kísérleti módszerek bemutatását (3. fejezet) az eredmények ismertetése (4. fejezet) követi. A 4.1 fejezetben elsőként a tanulmányozott ligandumok és a [Ru(II)- $\eta^{6}-p$-cimol] kerül bemutatásra. A 4.2 fejezet a lehetséges kelátterápiás ligandumok oldategyensúlyát tárgyalja három- (Fe(III), $\mathrm{Al}(\mathrm{III})$ ) és kétvegyértékü ( $\mathrm{Cu}(\mathrm{II}), \mathrm{Zn}(\mathrm{II}))$ fémionokkal. A 4.3 fejezet foglakozik a [Ru(II)- $\eta^{6}-p$-cimol] komplexek speciációjával. Ezután a vizsgált kelátorok, és rákellenes hatású fémkomplexek humán szérum albuminnal való kölcsönhatását mutatom be röviden (4.4 fejezet). 


\section{Irodalmi előzmények}

\subsection{Fémionok szerepe, és kelátor molekulák alkalmazása a neurodegeneratív elváltozásokban}

Az utóbbi évtizedekben a fejlett országokban a javuló életkörülményeknek, a vakcinációnak, és az orvostudomány fejlődésének köszönhetően ma már tovább élhetünk, mint a XIX. században. A várható élettartam meghosszabbodásával azonban egyre nagyobb az esélye krónikus és ,időskori” betegségek kialakulásának. Becslések szerint kb. 25 millió, föként hatvan év feletti ember szenved neurodegeneratív betegségekben, KeletEurópában számukat 1,8 millió före (2005. Delphi konszenzus vizsgálat adatai alapján), hazánkban 150-160 ezer före becsülik. ${ }^{1,2}$ A XX. század csendes járványának tartott Alzheimer-kór a leggyakoribb demenciás kórkép.

Annak ellenére, hogy Alois Alzheimer 1907-ben, több mint 100 éve írta le elöször a kórt, kialakulásának okát és patofiziológiáját még ma sem ismerjük pontosan. Kialakulása több tényezővel függhet össze. Komoly kockázati tényezőt jelenthet a gyakori vagy tartós oxigénhiány (hegymászók, búvárok), az elszenvedett koponyatraumák (bokszolóknál kialakuló dementia pugilistica), genetikai hajlam, és az életkor előrehaladásával járó élettani változások, pl. a neuroendokrin rendszer változása (meno- és andropauza után), kardiovaszkuláris problémák, alváshiány, stb. Kialakulására vonatkozó számos elmélet létezik, ami szintén bizonyítéka annak, hogy a gyakorlatban még ma is sok a megválaszolatlan kérdés a betegséggel kapcsolatban. A kolinerg hipotézis szerint az acetilkolin neurotranszmitter szintjének csökkenése váltja ki a betegséget. ${ }^{3}$ Más elmélet szerint a kolinerg hatás változása, az amiloid aggregáció, az oxidatív stressz, koleszterin anyagcsere kóros változása vagy gyulladásos folyamatok játszhatnak szerepet a kór kialakulásában. ${ }^{4,5,6,7,8}$ Azonban abban egyetértés van, hogy az $\beta$-amiloid fehérjék aggregációja a hippocampusban és az agykéregben - akár kiváltó okként, akár végső következményként - kulcsszerepet játszik a betegség kórélettanában. A kialakult hibás szerkezetü fehérjék, és kóros szupramolekuláris szerkezetek miatt is definiálják az Alzheimer-kórt a helytelen térszerkezetü (misfolding) fehérje betegségként. Az $\beta$-amiloid fehérjék az amiloid prekurzor protein (APP) kóros hasítása következtében keletkező peptidek. Fiziológiás körülmények között is képzödnek a központi idegrendszerben, normál esetben azonban nem mutatnak aggregációs hajlamot. Az APP egy transzmembrán fehérje, amely az idegsejtek szinaptikus membránjában nagy mennyiségben van jelen. 
Pontos funkcióját ma sem ismerik. Rendellenes körülmények között az APP-ről béta- és gamma-szekretázok hatására hibás szerkezetü, részleges helikális struktúrát mutató, 40-42 aminosavból álló $\beta$-amiloid fehérjék hasadnak le $\left(\mathrm{A} \beta_{42}\right)$, amik önmagukban még nem toxikusak, azonban könnyen $\beta$-redő szerkezetet vehetnek fel, és így aggregációra hajlamossá válnak (,amiloidogének”). 9,10,11 A szinaptikus résben oligomerek, diffúzibilis aggregátumok és fibrillumok, végső soron diffúzibilis és szenilis plakkok alakulnak ki, melyek toxikus hatást fejtenek ki a környező neuronokra. ${ }^{12}$ A kóros folyamatok végső következménye az idegsejtek elhalása és a szinapszisok számának drasztikus csökkenése, mely fiziológiásan a feledékenység, figyelem- és viselkedés zavar, szellemi hanyatlás, az úgynevezett „második gyermekkor” tüneteinek kialakulásához vezet. ${ }^{13}$ A kór lefolyása napjainkban még visszafordíthatatlan, csak szinten tartani lehetséges.

Az aggregáció oka a mai napig nem tisztázott, számos faktor $(\mathrm{pH}$, fémionok homeosztázisának változása, oxidatív stressz, a hibás szerkezetü fehérjék koncentrációjának növekedése) kiváltó oka lehet. ${ }^{14}$

Az 1990-es évektől sorra jelentek meg az irodalomban olyan publikációk, melyek a fémionok szerepét hozták összefüggésbe az Alzheimer-kór kialakulásával. A mai napig számos kísérlet utal arra, hogy a fémion háztartás megváltozása hatással lehet az aggregációs folyamatokra, a toxikus $\beta$-amiloid oligomer formák kialakulására és a plakk képződésre. ${ }^{15,16,17}$ Bár egy kritikus koncentráció felett, túltelített oldatban az $\mathrm{A} \beta_{42}$ önmaga is képes aggregálódni, a fémionok képesek meggyorsítani ezt a folyamatot. ${ }^{18}$

A $\beta$-amiloid fehérjék valóban képesek lehetnek fémionok (Al(III), $\mathrm{Fe}(\mathrm{III}), \mathrm{Cu}(\mathrm{II})$, $\mathrm{Zn}(\mathrm{II}))$ megkötésére. A $\mathrm{Cu}(\mathrm{II})$ és $\mathrm{Zn}(\mathrm{II})$ ionok a fehérje hisztidin és tirozin oldalláncaival képesek kialakítani koordinatív kötést, ${ }^{19}$ míg a hard jellegü Al(III) és Fe(III)-hoz az oxigén donoratomot tartalmazó aminosav oldalláncok koordinálódhatnak (aszparaginsav, glutaminsav, szerin, tirozin). ${ }^{18}$ A megkötődött fémionok képesek indukálni vagy gyorsítani a $\beta$-redő szerkezet kialakulását, így a $\beta$-amiloid kezdeti oligomerizációját, majd aggregációját. A képződött szupramolekuláris szerkezetek is képesek lehetnek fémionok megkötésére, sőt a megkötődött fémionoknak szerepe lehet különféle reaktív gyökök képződésében, toxikus folyamatok lejátszódásában.

$\mathrm{Az}$ élettani funkcióban a fémionok szerepe létfontosságú, számos biokémiai folyamatban vesznek részt a sejtekben. Becslések szerint az enzimek közel egyharmada tartalmaz valamilyen fémiont ${ }^{20}$. A fémion-homeosztázis fenntartása ezért kritikus tényező az normál életmüködések szempontjából. Egészséges szervezetben a fémion-homeosztázis 
egy bonyolult, szigorúan és finoman szabályozott rendszer, melynek zavara beláthatatlan következményekhez vezet. Különösen érvényes ez a többértékü fémionokra, mint pl. a rézre és vasra, melynek redoxi egyensúlyának megváltozása oxidatív stresszhez vezet, megnövelve a reaktív oxigén származékok (ROS) mennyiségét, ami számos biológiailag fontos molekula károsodását okozhatja. Bár testtömegünk kb. csupán $2 \%$-a az agy, az egyik oxigénnel legbőségesebben ellátott szervünk. A keringő vér oxigén-tartalmának 20\%-a itt kerül felhasználásra. ${ }^{21}$ Az oxidatív egyensúly rendkívül szigorúan szabályozott, aminek felborulása igen komoly következményekkel jár az agy szövetek különös érzékenysége és kismértékű regenerációja miatt. ${ }^{22}$ Reaktív oxigén származékoknak tekintjük a molekuláris $\mathrm{O}_{2}$-ből kialakult reakcióképes termékeket, mint pl. a szuperoxid aniont $\left(\mathrm{O}_{2}{ }^{-}\right)$, a hidroxilgyököt $\left({ }^{\circ} \mathrm{OH}\right)$, az alkoxil gyököt ( $\left.{ }^{\circ} \mathrm{RO}\right)$, vagy a hidrogén-peroxidot $\left(\mathrm{H}_{2} \mathrm{O}_{2}\right)$. A ${ }^{\circ}{ }_{2}^{-}$föként a mitokondriumban keletkezik molekuláris oxigénből. A gyök a Haber-Weiss reakció (1) során redukálni képes a $\mathrm{Fe}(\mathrm{III})$ és $\mathrm{Cu}(\mathrm{II})$ ionokat, a vízzel reakcióba lépve $\mathrm{H}_{2} \mathrm{O}_{2}$-á alakulhat, melyet a szuperoxid-diszmutáz (SOD) enzim katalizál. A $\mathrm{H}_{2} \mathrm{O}_{2}$ már sokkal stabilisabb, és képes áthatolni a membránokon is. Az ún. Fentonreakcióban (2) $\mathrm{Fe}(\mathrm{II})$-el vagy $\mathrm{Cu}(\mathrm{I})$-el reagálva ${ }^{\circ} \mathrm{OH}$-é alakulhat. ${ }^{23}$

$$
\begin{aligned}
& \mathrm{M}(\text { ox })+{ }^{\circ} \mathrm{O}_{2}{ }^{-} \rightarrow \mathrm{M}(\text { red })+\mathrm{O}_{2} \\
& \mathrm{M}(\text { red })+\mathrm{H}_{2} \mathrm{O}_{2} \rightarrow \mathrm{M}(\mathrm{ox})+\mathrm{OH}^{-}+{ }^{\cdot} \mathrm{OH}
\end{aligned}
$$

A reaktív oxigén származékok túl nagy koncentrációban jelentősen károsíthatják a sejtek biomolekuláit, különösen a nukleinsavakat, lipideket és a fehérjéket. ${ }^{24,25,26,27,28}$

$\mathrm{Az} \beta$-amiloid peptidek önmaguk is képesek redukálni a $\mathrm{Cu}(\mathrm{II})$ és $\mathrm{Fe}(\mathrm{III})$ ionokat miközben a benne lévő metionin metionin-szulfoxiddá oxidálódik. ${ }^{29,30,31}$ A hisztidin oldalláncokhoz kötött réz - tekintettel a natív enzimek aktív centrumában található rézion multihisztidines koordinációs módjával való hasonlóságára - redoxi reakciók katalizálására lehet képes. A redukált fémionok mennyiségének növekedése pedig további ROS képződést generál.

$\mathrm{Az}$ alumínium nem esszenciális fém az emberi szervezet számára. A természetben biológiai hozzáférhetősége korlátozott, rosszul oldódó hidroxidok, szilikátok, foszfátok formájában fordul elő. Azonban napjainkban, „az alumínium korában” szervezetünk alumínium terhelése megnövekedett. ${ }^{32}$ Számtalan forrásból kerülhet a szervezetünkbe (alumínium edények, gyógyszerek, kozmetikumok, élelmiszer adalékanyagok, stb.). ${ }^{33,34,35,36} \mathrm{Az} \mathrm{Al}(\mathrm{III})$ felszívódását a gyomor és bélrendszer hatékonyan gátolja, így annak nagy része kiürül, egy része azonban képes lehet felszívódni, és súlyos károsodást okozni. $^{37}$ A felhalmozódott $\mathrm{Al}(\mathrm{III})$ elismerten neurotoxikus hatású, ${ }^{38}$ szerepe az 
Alzheimer-kórban azonban még nem tisztázott. Elösegítheti a túlfoszforilált tau-fehérjék rendellenes fonadék képződését, a $\beta$-amiloid fehérjék aggregálódását. ${ }^{39,40}$ Habár nem redox aktív fém, egyes tanulmányok szerint az alumíniumnak is szerepe lehet az oxidatív stressz redoxi folyamataiban, mint „pro-oxidánsnak”. ${ }^{\circ} \mathrm{O}_{2}^{-}$-al reagálva egy ún. alumíniumszemiredukált-szuperoxid gyök kation keletkezik (3), mely képes katalizálni a $\mathrm{H}_{2} \mathrm{O}_{2}$ képződését (4) és a Fe(III) redukcióját (5), minek folytán az alumínium is jelentősen hozzájárulhat az oxidatív stressz okozta károsodáshoz. ${ }^{41,42,43}$

$$
\begin{aligned}
& \mathrm{O}_{2}{ }^{-}+\mathrm{Al}^{3+} \leftrightarrow \mathrm{AlO}_{2}{ }^{2+} \\
& \mathrm{AlO}_{2}{ }^{2+}+2 \mathrm{H}^{+} \rightarrow \mathrm{H}_{2} \mathrm{O}_{2}+\mathrm{O}_{2}+2 \mathrm{Al}^{3+} \\
& \mathrm{Fe}^{3+}+{ }^{3+} \mathrm{AlO}_{2}{ }^{2+} \rightarrow \mathrm{Fe}^{2+}+\mathrm{O}_{2}+\mathrm{Al}^{3+}
\end{aligned}
$$

A cinkion rendkívül fontos és szerteágazó szerepet játszik a normál agyi működésben, szignáltranszdukciós folyamatokba. Glutamáterg rendszerekben fontos ingerületátvivő anyag. ${ }^{44}$ A sejten belül a glutaminsavval együtt szinaptikus vezikulumokban halmozódik fel a ZnT3 transzporterek müködése folytán, és együtt ürülnek a szinaptikus résbe, ahol időlegesen akut $\mathrm{Zn}$ (II) többlet alakul ki $(\sim 1 \mathrm{mM}) .{ }^{45}$ A cinkionok szerepe az Alzheimer-kór kialakulásában még nem tisztázott, és sokszor nehéz tisztán látni az egymásnak ellentmondó irodalmi közlemények között. Egyes kutatók a Zn(II) többletet tartják az egyik legfontosabb rizikófaktornak. Más közleményben arról olvashatunk, hogy azoknál a kísérleti egereknél, melyekben a hibás ZnT3 cink transzporter fehérje nem képes a cinkionokat a szinaptikus vezikulumokba felhalmozni, és így a cinkhiány lép fel a szinapszisokban, épp az alacsony cinkkoncentráció okozhat neurodegeneratív elváltozásokat. ${ }^{46}$ Arról is olvashatunk, hogy a toxikus cinktöbblet $\beta$-amiloid-Zn(II) depozitokban kötődik meg, és így hosszú távon cinkhiány lép fel ezeken a területeken.

Van azonban néhány tény, amelyben a legtöbb kutató egyetért. Egyik ilyen, hogy a $\beta$ amiloid fehérje lerakódás kifejezettebb a glutamáterg rendszerben gazdag agyi régiókban, ahol a szinaptikus résbe ürülő cinkionok fontos szerepet játszanak az ingerület átvitelben. Kevés kétség merül fel azzal kapcsolatban is, hogy a $\mathrm{Zn}$ (II) képes indukálni az $\beta$-amiloid fehérjék aggregálódását. ${ }^{47} \mathrm{Ez}$ a folyamat reverzibilis, kelátor molekulákkal (EDTA, kliokinol) a Zn(II) elvonásával visszafordítható, és a plakkok feloldódnak. Azonban az, hogy cinkionok kölcsönhatása a $\beta$-amiloid peptidekkel toxikus oligomerek kialakulásához vezet-e, ${ }^{48}$ vagy épp neuroprotektív folyamatként az aggregálódást segítve a toxikus oligomerformák mennyiségét csökkenti-e, ${ }^{49,50}$ és valójában cinktöbblet esetén a $\mathrm{Zn}$ (II) direkt hatása az, ${ }^{51,52,53}$ ami a neuronokat károsítja, még nem tisztázott kérdés. Azonban 
valószínü, hogy a cink-homeosztázis zavara, akár csak a többi fémioné hozzájárulhat a betegség kifejlődéséhez. A kor előrehaladásával az agy vas-, réz-, cink- és alumíniumion tartalma növekszik, és a kor az egyik legmagasabb rizikófaktora az Alzheimer-kórnak. ${ }^{54}$

A betegség ma még nem gyógyítható, kezelése a tünetek enyhítésére, és a betegség kifejlődésének lassítására szorítkozik. Megfelelő terápia kifejlesztését nem csak az nehezíti, hogy kialakulásának oka, és pontos folyamata még ma sem ismert, hanem az is, hogy jól csak előrehaladott stádiumban diagnosztizálható. Sok esetben feltételezik, hogy vitaminok, gyulladáscsökkentők, keringés javító gyógyszerek, és az agy folyamatos „tornáztatása”, az egészséges életmód enyhe tünetek jelentkezésekor jótékony hatással lehet a betegség kifejlődésének megakadályozásra. ${ }^{55,56,57}$ Enyhébb és középsúlyos esetekben a gyakorlatban kolinészteráz-gátló kezelést javasolnak, mely gátolja az acetilkolin lebontását, meghosszabbítva annak hatóidejét így kompenzálja a neurotranszmitter csökkenő mennyiségét. ${ }^{58}$ Középsúlyos és súlyos betegség esetén főként memantine szedése javasolt, mely képes NMDA-receptor (glutamáterg-receptor) antagonistaként a receptorhoz kötve megakadályozni a Ca(II)ionok sejtbe jutását. ${ }^{59,60} \mathrm{~A}$ betegség során ugyanis a megnövekedett glutamátszint miatt a csatornák nyitott helyzete következtében a sejtek károsodását és pusztulását a kalciumszint növekedése is elősegíti. Ezek a kezelések sok esetben nem hatásosak, és mellékhatásokkal járnak. A solanezumab és a bapineuzab két olyan klinikai III. fázisban lévő hatóanyag molekula, melyek képesek a $\beta$-amiloid fehérjékhez kötődni, és ily módon az aggregációjukat gátolni. ${ }^{61}$ Klinikai I. fázisban vannak olyan antigén molekulák is, melyek a $\beta$-amiloid képződésért felelős enzimet lehetnek képesek gátolni. ${ }^{62}$

Mivel a fémkelátorok lassítják az $\beta$-amiloid aggregációját, így merült fel a kelátterápia, mint lehetőség az Alzheimer-kór gyógyításában. Azokat a kelátor molekulákat, amelyek képesek versengeni a $\beta$-amiloid fehérjék által kötött fémionokért az irodalom közös néven „metal-protein attenuating compound-nak” (MPAC) nevezi. A kelátor molekulák hatásának vizsgálata a fémionok indukálta $\beta$-amiloid aggregáció illetve diszaggregációjával kapcsolatosan az 1990-es években kezdődött. ${ }^{63,64}$ Elsőként olyan nem specifikus fémkötő ligandumok aggregációt befolyásoló hatását vizsgálták, mint az EDTA (etilén-diamin-tetraecetsav), DTPA (dietilén-triamin-pentaecetsav), EGTA (etilénglikol-

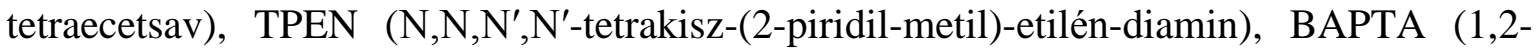
bisz(o-amino-fenoxi)-etán-N,N,N',N'-tetraecetsav), batokuproin (2,9-dimetil-4,7-difenil1,10-fenantrolin), vagy batofenantrolin (4,7-difenil-1,10-fenatrolin) (1. ábra). 

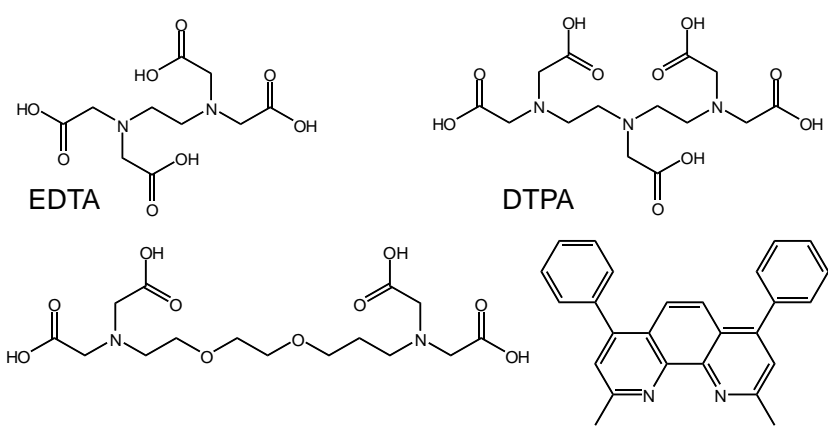

EGTA

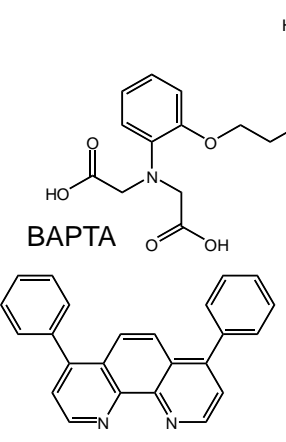

Batokuproin

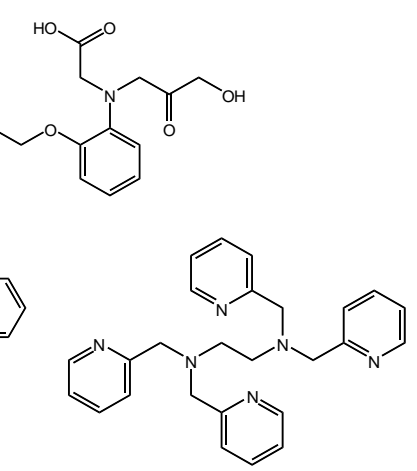

TPEN

1. ábra: „Első generációs” fémkötő kelátorok

Ezek az ún. „első generációs” fémion kelátorok az erős fémkötő sajátságaiknak köszönhetően képesek voltak a plakkok szolubilizálására, azonban nem képesek szelektíven megkötni a fémionokat, hidrofil sajátságuk miatt a vér-agy gáton való átjutásuk korlátozott, ezért további in vivo vizsgálatra alkalmatlanok. ${ }^{63,64,65}$

A szervezet fémion túlterheltsége ( $\beta$-talasszémia, Wilson-kór, nehézfém-mérgezés) esetén az orvosi gyakorlatban eredményesen alkalmaznak fémion kelátorokat a rendellenesség kezelésére. Ilyen kelátor pl. a deferipron (DFP), deszferrioxamin (DFO), exjade $\beta$-talasszémiás betegség esetén, a trientin és D-penicillamin (DPA) a Wilson-kór kezelésében (2. ábra). ${ }^{66}$

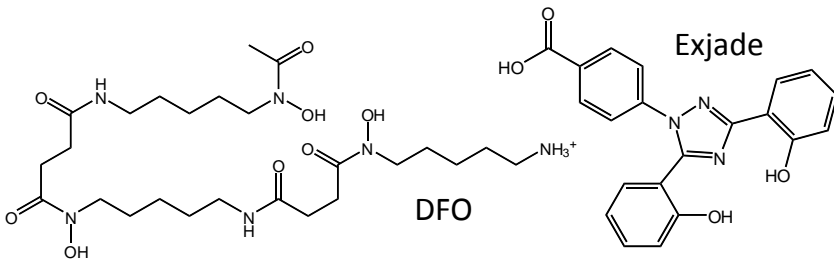

2. ábra: A szervezet fémion túlterheltsége esetén alkalmazott kelátorok

Kézenfekvőnek tünt annak vizsgálata, hogy a már klinikai alkalmazásban is használt fémkelátorok hogyan befolyásolják fémion indukálta $\beta$-amiloid aggregációt. Habár az in vitro kísérletekben a ligandumok képesek lassítani, vagy visszafordítani az amiloid fehérje aggregációját, ezek a kelátorok a szervezet egészére hatnak és csak nehezen jutnak át a vér-agy gáton. A ligandumok módosításával azonban elérhető, hogy a kelátor bekerüljön az agyba, és ott specifikusan fejtse ki fémkötő hatását az amiloid fehérjék közelében. A deszferrioxaminnal ellentétben, melyet infúzióval juttatnak a beteg szervezetébe, a deferipron szájon át szedhető gyógyszer. Jó antioxidáns, és alacsony citotoxicitású, kis lipofilitása miatt azonban nem alkalmas arra, hogy a vér-agy gáton átlépjen, és a $\beta$-amiloid plakkok közelében fejtse ki hatását. A molekula vázát megtartva, de vázon lévő 
szubsztituensek változtatásával jobb permeabilitás, specifikusabb hatás érhető el, és az antioxidáns tulajdonság is fokozható. Az agy nagy energiaigénye miatt a glukóz transzport igen aktív, így a hatékonyabb bejutást segítheti, ha a molekulára egy cukorrész kerül, ${ }^{67}$ másrészt a cukorrész javítja az oldhatóságot vizes közegben. ${ }^{68}$ Hasonló, sikeres kutatások folytak a Parkinson kór esetében is, ahol dopaminra épített cukor egység segítette a molekula átjutását a vér-agy gáton a GLUT-1 transzporteren keresztül. ${ }^{69,70,71}$ Ígéretes kutatások folynak aminosav konjugátumokkal is. ${ }^{72,73,74}$ Kísérletek folynak azzal kapcsolatban is, hogy a fent említett gliko-kelátor-konjugátumok közvetlenül a $\beta$-amiloid plakkok közelében, specifikusan fejtsék ki hatásukat. Ha például a molekulára egy tioflavin részt építettek, az közvetlen képes kapcsolódni a $\beta$-redő szerkezetben gazdag amiloid aggregátumokhoz, így a kelátor a megfelelő helyen képes kifejteni hatását. ${ }^{75} \mathrm{~A}$ tioflavin-T DTPA-val alkotott vegyületéről szintén bebizonyosodott, hogy a vér-agy gáton átjutva képes az aggregáció visszafordítani, azonban a képződő $\beta$-amiloid oligomerek toxikus hatásúnak bizonyultak. ${ }^{76} \mathrm{Az}$ antioxidáns hatású transz-sztilbén és imidazopiridin $\beta$ amiloid fehérjét szelektíven felismerő vegyületek módosítása és bifunkciós kelátorként való alkalmazása azonban a jelenlegi kutatások alapján ígéretes. ${ }^{77,78} \mathrm{~A}$ deferipronhoz hasonló 2-amido-3-hidroxipiridin-4-on származékok, mint vaskelátorok neuroprotektív hatásúnak bizonyultak a $\beta$-amiloid fehérjék indukálta sejtkárosodás ellen. ${ }^{72}$ Gyürüben lévő nitrogénhez butil-hidroxi-toluol származékokat kapcsolva a molekula antioxidáns hatása javítható amellett, hogy a deferipron rész megőrzi kelátor funkcióját. ${ }^{79,80}$ Legújabb kísérletekben a kelátor molekulákat, mint pl. a derferipront is, nanorészecskékhez kapcsolják, hogy így növeljék a vér-agy gáton való transzport hatékonyságát. ${ }^{81}$ Míg a deferipron $\mathrm{Fe}(\mathrm{III})$ és $\mathrm{Al}(\mathrm{III})$ kelátorként alkalmazható, a 'szoftabb' jellegü $\mathrm{Cu}$ (II) és $\mathrm{Zn}$ (II) fémionok $\beta$-amiloid plakkokból való eltávolítására alkalmasabb lehet a 8-hidroxikinolin vázas kliokinol molekula (3. ábra). Cherny és munkatársai megfigyelték, hogy kliokinol hatására javul a beteg egerek mentális állapota, illetve lassítja, sőt vissza is fordítja a $\beta$ amiloid aggregátumok képződését, azonban alkalmazása nem megengedett, mert Japánban az alkalmazása során több esetben neuropátiás tünetek léptek fel. ${ }^{82} \mathrm{~A}$ molekula módosításával, és kelátorként való alkalmazásával azonban még ma is számos kutatócsoport foglalkozik. Az egyik ilyen módosítás éppen a mellékhatásának kivédésére szolgáló aminosavakból álló neuroprotektív csoport 8-hidroxikinolin vázhoz való kapcsolása. ${ }^{83,84,85,86} \mathrm{Az}$ aminosavak, illetve a deferipron származékainak tárgyalásához hasonlóan, nanorészecskék vázhoz való kötődése segíti a hidroxikinolin vér-agy gáton való 
átjutását. ${ }^{83,87}$ A molekula fenolos hidroxilcsoportjának „maszkolása” bórsav-észteres származék formájában specifikus hatást tesz lehetővé. ${ }^{88}$ A kelátképzéshez fontos fenolos hidroxilcsoport csupán $\mathrm{H}_{2} \mathrm{O}_{2}$ hatására válik szabaddá, amely az Alzheimer-kóros betegek agyában a $\beta$-amiloid plakkok közelében a $\mathrm{Fe}(\mathrm{III})$ és $\mathrm{Cu}$ (II) fémionok indukálta oxidatív stressz hatására magasabb koncentrációban van jelen. ${ }^{88}$ Jelenleg az ismeretlen szerkezetű, de hidorxikinolin váz alapú ún. PTB2 származék van klinikai II. vizsgálati fázisban, amely mind a fehérje aggregációt, mind a $\mathrm{H}_{2} \mathrm{O}_{2}$ szintet képes csökkenteni. ${ }^{89,90}$

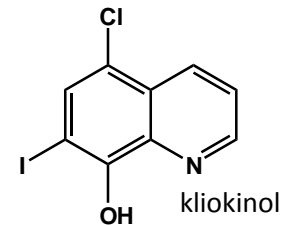<smiles>CNCc1ccccn1</smiles><smiles>NCCNCc1ccccn1</smiles>

3. ábra: $\mathrm{Cu}(\mathrm{II})$ és $\mathrm{Zn}(\mathrm{II})-\mathrm{kötő} \mathrm{kelátorok}$

A Tanszékünkön már korábban is történtek kísérletek moderált cinkkötő képességgel rendelkező kelátor molekulák kifejlesztésére. A TPEN ( $\mathrm{N}, \mathrm{N}, \mathrm{N}^{\prime}, \mathrm{N}^{\prime}$--tetrakisz(2piridilmetil)etiléndiamin) cinkkomplexei igen nagy stabilitásúak, emiatt igen toxikus (biológiában a szabad cink meghatározására használják), azonban a molekula „elfelezésével” illetve „elnegyedelésével” már jóval enyhébb fémkötő képességü ligandumot nyerünk. ${ }^{91}$ A DMAP ( $N$-metil-1-(piridine-2-il)-metánamin) (3. ábra) Zn(II) és $\mathrm{Cu}$ (II)-kötő képessége gyenge, nem elég hatékonyan képes versengeni a $\beta$-amiloid fehérjékben kötött fémionokért. ${ }^{91}$ Az ENDIP $\left(N^{1}, N^{2}\right.$-bisz(piridin-2-il-metil)etán-1,2diamin) (3. ábra) ligandum azonban fiziológiás $\mathrm{pH}-\mathrm{n}$ mindkét fémionnal elég nagy stabilitású 1:1 összetételü komplexet képez ahhoz, hogy kivonja a fémionokat az amiloid komplexéből és így képes gátolni a fémion indukálta $\beta$-amiloid oligomerizációt. ${ }^{91}$ Hasonlóan ígéretes eredmények születtek hisztidin gazdag oligopeptidekkel is. ${ }^{92}$

$\mathrm{Az}$ újabb, jobb tulajdonsággal rendelkező kelátormolekulák felkutatása ma is aktuális feladat.

A felhalmozódott, aggregálódást elősegítő fémionok eltávolítására alkalmas ligandumok lehetnek a különböző piridin-hidroxikarbonsav származékok, melyeket a Padovai Egyetemen állítottak elő a szervezetben lévő felesleges vas- és alumíniumionok eltávolítására. A vegyületekkel való vizsgálatok is a Padovai Egyetemmel együttmüködve történnek. A vegyületcsalád két legegyszerübb tagja a DQ0 (4-hidroxi-3-piridinkarbonsav) és a DT0 (3-hidroxi-4-piridinkarbonsav). Az egymással orto helyzetben lévő fenolos hidroxil- és karboxilcsoport egy hattagú, szalicilát típusú koordináció kialakítására képes. A gyürüben lévő nitrogén azonban a szalicilsav komplexekhez képest stabilabb komplexek 
kialakítását teszi lehetővé. Az 1990-es évek végén az olasz kutatócsoport már vizsgálta a kereskedelemben kapható 2-hidroxi-nikotinsav és 3-hidroxi-pikolinsav fémkötő képességét Fe(III), Al(III) és Zn(II)ionokkal. ${ }^{94}$ Összehasonlítva a DQ0 és DT0 fémkomplexek stabilitását a korábban vizsgált szubsztituensekkel, megállapítható, hogy az újonnan szintetizált ligandumok fémkötő képessége nagyságrendekkel nagyobb. ${ }^{93,94,183}$ A gyürün lévő metil-szubsztituensek elektronküldő hatásuk révén szintén erősebb koordinációs kötés kialakulását tehetik lehetővé.

A Szegedi Tudományegyetemen az előállított ligandumok réz- és cinkionokkal való kölcsönhatását vizsgáljuk, mert habár ezeket a ligandumokat elsősorban hard fémionok (Fe(III), $\mathrm{Al}(\mathrm{III}))$ megkötésére tervezték, réz- és cinkion esetében elég, ha kisebb stabilitással kötik a fémiont, itt ugyanis a fő cél a megbomlott fémion-háztartás visszaállítása, és nem a fémfölösleg minimálisra csökkentése.

Mivel feltehetően, a gyógyászati célra megfelelő és alkalmazásra kerülő ligandumok a véráramban szállítódnak, kölcsönhatásuk fontos lehet különböző vérben lévő molekulákkal, elsősorban az albuminnal. A ligandum humán szérum albuminnal való kölcsönhatását UV-látható spektrofotometriás ultraszürésessel, és spektrofluorimetriás mérésekkel vizsgáltuk.

\subsection{Rákellenes hatású fémkomplexek}

A rákos megbetegedések napjaink egyik leggyakoribb és legfélelmetesebb betegségei. Európában és az Egyesült Államokban is az egyik vezető halálok, gyógyítása az egészségügy egyik legnagyobb kihívása. ${ }^{95,96}$ A rák kifejezés sokféle, egymástól eltérő daganatos megbetegedés közös neve és nagyon valószínütlen, hogy valaha is kifejleszthető lesz a gyógyítására egységes eljárás. A betegség kezelhető direkt sebészeti úton és sugárkezeléssel, legeredményesebben akkor, ha a rákos daganat kiterjedése még csak a szervezet egyetlen helyére, körülírt területére korlátozódik. A kemoterápiának önmagában, vagy kiegészítő kezelésként jelentős szerepe van a gyógyításban. A lokális kezeléssel szemben elönye, hogy áttétek esetén is sikeresen alkalmazható, és alkalmazása nem szorítódik a szolid (körülírt) tumorok kezelésére. A fémkomplexek csak nagyon kis csoportját képezik a rákellenes gyógyszeres terápiának, mégis a rákellenes kemoterápia jelenleg egyik leghatásosabb vegyületei a platinavegyületek (4. ábra). ${ }^{97} \mathrm{~A}$ rákos megbetegedések mintegy felénél használnak valamilyen forgalomban lévő platinakomplexet. A platina(II)komplexek története az 1960-as években kezdődött, mikor 
Rosenberg felfedezte a ciszplatin sejtosztódás gátló hatását. ${ }^{98,99}$ Azóta a hatásmechanizmusát is sikerült tisztázni, a citotoxikus hatás a DNS replikációjának gátlásán alapul. ${ }^{100}$ A fémionhoz síknégyzetes geometriában két nehezen távozó ammónia ligandum, és két könnyen távozó klorid ligandum koordinálódik (4.a ábra), mely a környezet kloridion koncentrációjának függvényében vízmolekulára cserélődhet. A sejtben valószínüleg ez utóbbi forma aktív, és képes a DNS N-tartalmú bázisaihoz koordinálódni, és a sejtosztódást gátolni. ${ }^{101,102}$ A ciszplatin vegyület mellett két másik Pt(II)komplexet alkalmaznak a klinikumban: a karboplatint és az oxaliplatint (4.b. és c. ábra). ${ }^{103,104}$ Jelentős kísérletek folynak a pikoplatinnal is (4. d. ábra), mely a ciszplatintól annyiban tér el, hogy az egyik ammónia helyett egy pirimidin gyürü foglal helyet, amely képes lehet megakadályozni a sejtekben a glutationnal való kölcsönhatást, amely a rezisztencia kialakulásának egyik jelentős okozója. ${ }^{105,106} \mathrm{~A}$ rákellenes platinakomplexek egy új generációja a $\mathrm{Pt}(\mathrm{IV})$ komplexek. A Pt(IV)vegyületek oktaéderes geometriájúak, azonban a rákos sejtek közelében lévő reduktív környezetben Pt(II)vegyületté képesek redukálódni. Érdekes ötlet az etakraplatin esete (4.e. ábra). Az átalakulás közben a komplex síknégyzetes ciszplatinná alakul, miközben elveszti két axiális ligandumát. A leszakadt ligandum maga is hatással van a rákos sejtre. Képes gátolni a glutation-S-transzferázt, mely enzim a rezisztencia kialakulásának egyik fö okozója. ${ }^{107}$

a.<smiles>N[PH3+](N)Cl</smiles>

b.

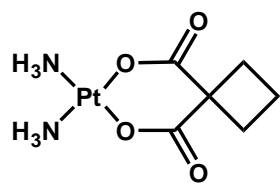

c.

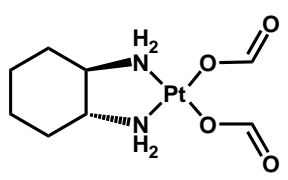

d.

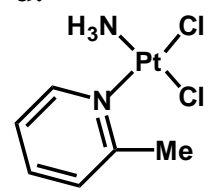

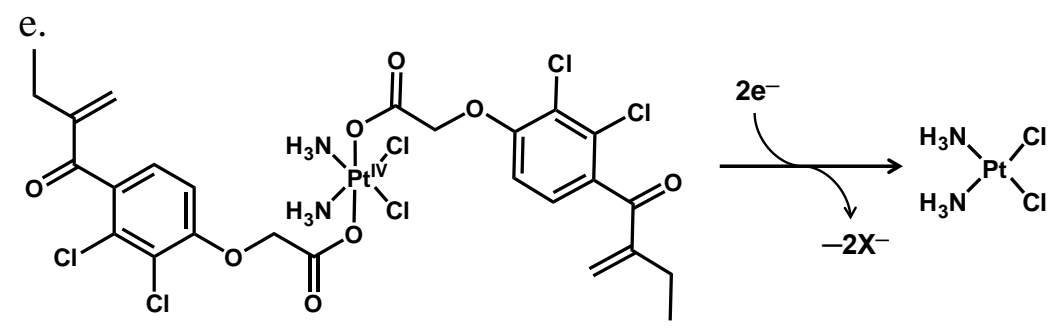

4. ábra: Platinakomplexek; Pt(II): a.) ciszplatin, b.) karboplatin, c.) oxaliplatin, d.) pikoplatin $\mathrm{Pt}(\mathrm{IV})$ : e.) etakroplatin és redukciója

A kemoterápia során a rezisztencia kialakulása a rákos sejtekben, illetve a terápia során fellépő mellékhatások sok esetben gátolják a gyógyulást. Tanulmányok szerint a ciszplatin nem halmozódik fel jelentős mértékben a rákos sejtekben, és csupán egy százaléka kötődik ténylegesen a DNS-hez. ${ }^{108,109,110}$ Ezért hatásos rákellenes terapeutikumok kifejlesztése ma is aktuális feladat. A platinakomplexeken túl számos kísérlet folyik nem platinaalapú 
fémkomplexekkel is. Aranykomplexek rákellenes hatásának vizsgálata az 1980-as évek óta folyik, miután az auronofin, reumás megbetegedéseknél alkalmazott Au(I)komplexről kiderült, hogy rákellenes hatása van, de ismertek más $A u(I I)-$ és $A u(I I I) k o m p l e x e k$ is. ${ }^{111,112,113} \mathrm{Az}$ aranykomplexek fö támadási pontja a fehérjékben lévő „,soft” kénatomok, így szelektivitásuk nem túl nagy, emiatt alkalmazásuk során súlyos mellékhatás léphet fel (proteinuria (fehérje vizelés), trombocitopénia (alacsony vérlemezkeszám), nefropátia, dermatitisz). ${ }^{114}$

Az elmúlt években számos ígéretes $\mathrm{Ru}(\mathrm{III})$ - és $\mathrm{Ga}(\mathrm{III})$ alapú vegyület vizsgálata is klinikai fázisba lépett. Intenzívebb kutatások folynak jelenleg is a Bécsi Egyetemen Bernhard K. Keppler kutatócsoportjában. Mindkét fémion a Fe(III)-hoz hasonlóan vizes oldatban már viszonylag kis pH-n hidrolizál ( $\mathrm{pH}$ 3-5 között), azonban a hidrolízis megfelelően erős komplexképző ligandumokkal visszaszorítható. ${ }^{115,116}$ Gallium esetében jelenleg a KP46 néven Ga-oxinát, [trisz(8-kinolinoláto)Ga(III)]), a Ga-maltolát, a Gapaullon és a Ga-tioszemikarbazon komplexeit (5. ábra) tanulmányozzák részletesen. ${ }^{117,118,119,120}$ Egyelőre nincsenek szerkezet-hatás összefüggések, amelyek segítenék a ligandumválasztást. A galliumvegyületek hatásmechanizmus ma még nem ismert. Feltételezések szerint a komplex a ribonukleotid reduktáz enzimet gátolja, amely dezoxiribonukleotidok szintéziséért felelős. A Ga(III)komplexek az enzim R2 egységében lévő tirozil-gyököt képesek destabilizálni. Emellett gátolni képesek a mitotikus orsó kialakulását is. ${ }^{121,122}$

Ru(III)alapú komplexek esetén legígéretesebb vegyületnek a NAMI-A (imidazólium transz[tetraklorido(dimetil-szulfoxid)(1H imidazol)rutenát(III)]) és KP 1019 (indazólium transz[tetraklorido(bisz(1H-indazol)rutenát(III)]), illetve annak jobb oldhatóságú nátrium sója (KP 1339) tüntek, melyek a rákos sejtekre szelektíven hatnak, így csak gyenge mellékhatással rendelkeznek (6. ábra). ${ }^{123,124,125,126}$ 
a.

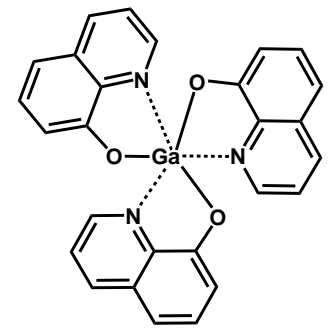

b.

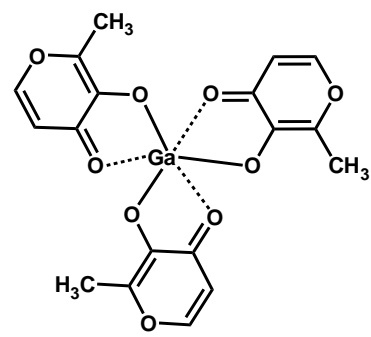

c.

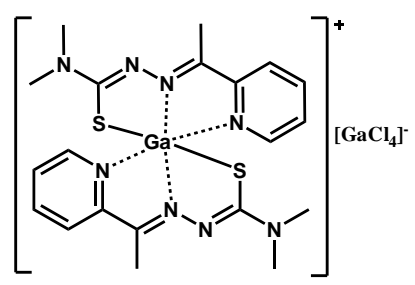

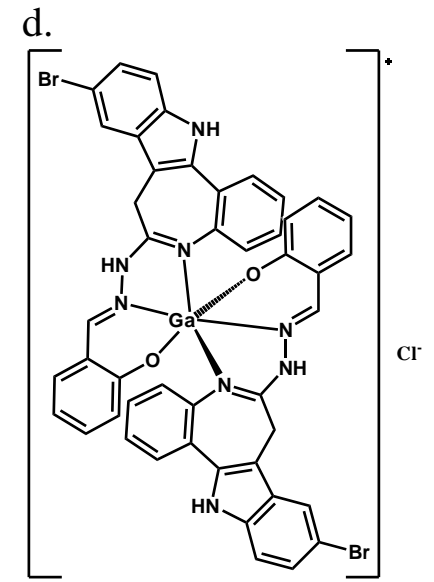

5. ábra: $\mathrm{Ga}(\mathrm{III})$ alapú rákellenes hatású komplexek a.) KP 46 (Ga(III)-oxinát), b.) Ga(III)-maltolát, c.) $\mathrm{Ga}(\mathrm{III})$-tioszemikarbazon, d.) $\mathrm{Ga}(\mathrm{III})$-paullon komplex

A Ru(III)tartalmú KP komplexek a primer, körülírt tumorokon bizonyultak hatásosnak, mint pl. a kolorektális karcinóma. A NAMI-A a metasztázisok kialakulását képes inkább lassítani azáltal, hogy befolyásolni képes az aktin függő sejtadhéziót és gátolja a mátrix metalloproteinázokat, akadályozva ezzel a kóros sejtcsoportok leszakadását és szóródását a szervezetben. ${ }^{127,128,129}$

a.

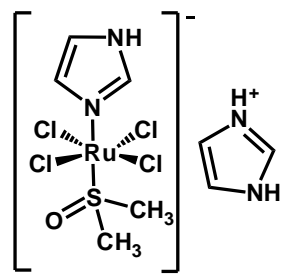

b.

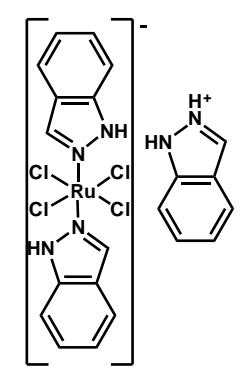

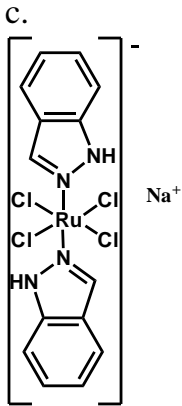

6. ábra: Ru(III)alapú rákellenes komplexek a.) NAMI-A, b.) KP1039 c.) KP1339

A $\mathrm{Ru}(\mathrm{III})$ komplexek in vitro nem rendelkeznek jelentős citotoxicitással, a szervezetben azonban szolid tumorok közelében a komplexben kötött $\mathrm{Ru}(\mathrm{III}) \mathrm{Ru}(\mathrm{II})$-vé képes redukálódni, megnövelve ezáltal a toxikus hatást. ${ }^{130,131} \mathrm{Az}$ irodalomban úgy is fogalmaznak: „redukció által aktiválódik”. A szolid tumorok ugyanis ún. „glikolát fenotípusúak" - gyors anyagcsere folyamataik következtében az oxigénszegény környezetben energiatermelésük fóként a glikolízisen alapul. ${ }^{132}$ A hipoxia és a kis pH-jú 
környezet (a laktodehidrogenáz és a tejsav jelenléte miatt) megfelelö reduktív környezetet biztosít a $\mathrm{Ru}(\mathrm{III})$ redukciójához. Valószínüleg ez lehet az oka annak, hogy nem szolid tumorok, pl. leukémia esetén a Ru(III)komplexei hatástalannak bizonyultak. ${ }^{132} \mathrm{~A}$ vérben keringő kis rákos sejtaggregátumok elpusztítására ezért alkalmasabb lehet közvetlenül

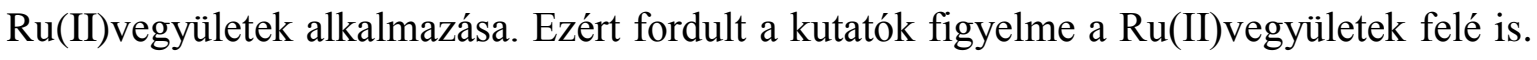
Ezek azonban oxidációra érzékenyek, így ezekben a vegyületekben a Ru(II)-t védeni kell. Kezdetben a rákos sejtekre citotoxikus hatású aminofoszfin komplexkel történtek kutatások, azonban a vegyület gyógyszerként való használata kis oldékonysága miatt korlátozott. A +2-es oxidációs állapot aromás vegyületekkel is stabilizálható. A félszendvics szerkezetü $\mathrm{Ru}(\mathrm{II})$-arén vegyületekben a $\mathrm{Ru}(\mathrm{II})$ ion haxohapto koordinációval hat egyenrangú fém-szén kötést létrehozva stabilizálódik. Az így kialakult torzult oktaéderes geometriájú $\mathrm{Ru}(\mathrm{II})$-monoarén komplexben a fémionnak ún. „zongoraszék” struktúrában három szabad koordinációs helye marad (7. ábra). ${ }^{133}$
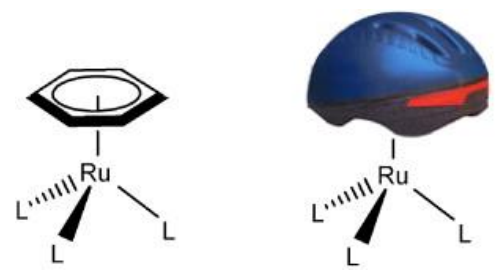

7. ábra: A félszendvics szerkezetű Ru(II)-arén vegyületekben az arén védi a fémiont az oxidációtól ${ }^{133}$

Az arénvegyület megválasztásával (benzol, cimol, toluol, bifenil, antracén...stb.) a $\mathrm{Ru}(\mathrm{II})$ komplex más tulajdonságát is befolyásolni lehet. Hidrofilitásával befolyásolni lehet a komplex biológiai membránon való átjutását, így a gyógyszermolekula könnyebben juthat be a sejtekbe, valamint kinetikailag labilissá teheti a ligandum szubsztitúciót. ${ }^{133}$ Kutatások azt igazolták, hogy az arén méretét és hidrofóbicitását növelve nő a komplex citotoxicitása is. $^{134,135}$

A koordinálódó ligandumok szintén befolyásolni tudják a komplex stabilitását, hidrofóbicitását, biológiai aktivitását. Vizes oldatban a Ru(II)-arén vegyületek többnyire már 4-es pH-n hidrolizálnak, azonban a szabad helyeken koordinálódni képes ligandumok képesek növelni a komplex stabilitását, így a biológiai hatását is. ${ }^{136} \mathrm{~A} \mathrm{Ru}(\mathrm{II})$-monoarén vegyületek egyik fontos családja a Ru(II)-RAPTA komplexek, melyben a központi fémion három szabad koordinációs helye közül egyhez a RAPTA, más néven pta (1,3,5-triaza-7foszfatriciklo-[3,3,1,1]dekánfoszin) ligandum koordinálódik monodentát módon, a másik 
két helyet pedig egy-egy könnyen távozó csoport (pl. kloridion, imidazol) foglalja el, melynek változtatásával befolyásolható a komplex hidrofóbicitása, szelektivitása (8. ábra).

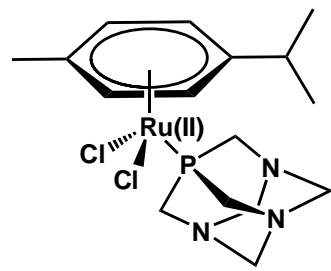

8. ábra: [Ru(II)- $\eta^{6}$-p-cimol]-RAPTA komplex

Másik csoportban a központi $\mathrm{Ru}(\mathrm{II})$ ionhoz kétfogú, $\mathrm{O}$, N, vagy $\mathrm{S}$ donorcsoportot tartalmazó ligandum koordinálódik. Sadler és munkatársai azt tapasztalták, hogy a megfelelő biológiai aktivitás kialakításához előnyösebb a kétfogú ligandum bidentát koordinálódása az egyfogúval szemben. Azt gondolják, a kelátgyürü segít stabilizálni a komplexet. Enélkül a vegyület túl reaktív és könnyen elreagál már a szérumbeli komponensekkel is. ${ }^{137}$ Bidentát koordináció esetén a harmadik helyet egy könnyen távozó csoport foglalja el. Ez gyakran halogenidion, leggyakrabban kloridion, ami oldatban a kloridion koncentrációtól függően részben vagy teljesen vízre cserélődhet. A biológiai vizsgálatok alkalmával általában a $\left[\mathrm{Ru}(\mathrm{II})-\eta^{6}\right.$-arén $\left.)\left(\mathrm{H}_{2} \mathrm{O}\right)\left(\mathrm{Cl}^{-}\right)\right]$juttatják be a sejtbe/szervezetbe. A bejutatott kloridokomplex a közeg kloridion koncentrációjától függően hatásosabb formájú akvakomplexszé alakul. Köztudott, hogy a szervezeten belül a kloridion koncentráció a vérszérum, sejtplazma, sejtmag irányba csökken, ${ }^{149}$ így megfelelő ligandum jelenlétében elérhető az, hogy a hatásosabb akvakomplex képződése a sejtmagban, a DNS közelében érje el a legnagyobb mértékét (vérplazma: 104 mM, sejtplazma: $24 \mathrm{mM}$, sejtmag: $\sim 4 \mathrm{mM}$ ).

Mind a távozó csoport, mind a koordinálódó ligandum fontos hatással van a $\mathrm{Ru}(\mathrm{II})$ komplex reaktivitásra. Egyrészt befolyásolják az akvakomplex arányát, másrészt az akvakomplex a koordinálódó vízmolekula deprotonálódásával hatással vannak koordinálódott vízmolekula deprotonálódására, azaz annak pK-értékére. A deprotonálódott $[\mathrm{Ru}(\mathrm{II})$-arén $(\mathrm{L})(\mathrm{OH})]$ hidroxidokomplex biológiailag kisebb aktivitású, mint a megfelelő akvakomplex. ${ }^{138}$ A semleges töltésű, bidentát módon koordinálódó etiléndiamin $\mathrm{Ru}(\mathrm{II})$ arén komplexeinek pK-értéke kb. 8-as érték, ${ }^{149}$ a ligandumot negatív töltésü acetilacetonra cserélve megnő az akvakomplex aránya, illetve a pK 9,4-re nő. ${ }^{139} \mathrm{~A} \pi$-akceptor tulajdonságú 4-(1H-pirazol-3-ilazo)-N,N-dimetilanilin a Ru(II)ionon kis elektronsűrüséget okoz, aminek hatására a pK 4,6-ra csökken. ${ }^{140}$ Emellett a szintén $\pi$-akceptor tulajdonságú azopirol az akvakomplexek arányára is kedvezőtlen hatással bír. ${ }^{140}$ 
A ligandum kötéserősségétől függően a komplex disszociálhat melynek következtében szabad ligandum és biológiailag kevésbé aktív kétmagvú $\left.\left[\mathrm{Ru}(\mathrm{II})-\eta^{6} \text {-arén }\right)_{2}(\mathrm{OH})_{3}\right]^{-}$komplex keletkezik.

A Ru(II)-arén vegyületek biológiai hatásmechanizmusáról egyelőre keveset tudni. Valószínüleg másképp hatnak, mint a platinavegyületek, ezért is lehetnek hatásosak ciszplatin rezisztens sejtvonalakon. Számos irodalom szerint a harmadik szabad koordinációs hely képes lehet a DNS guanin molekulájának nitrogén atomjához koordinálódni, azonban feltételezhető, hogy az antimetasztatikus hatását nem közvetlenül a DNS molekulához való kötődéssel fejti ki. Inkább tünik valószínűnek, hogy a sejtben lévő kén és nitrogén tartalmú fehérjékkel, enzimekkel (pl. kinázokkal) képes kölcsönhatásba lépni, és ezeken keresztül, indirekt módon gátolja a DNS szintézist. ${ }^{141,142}$

Az elmúlt években nagy figyelmet kaptak a $[\mathrm{Ru}(\mathrm{II})$-arén-( $\mathrm{O}, \mathrm{X}) \mathrm{Cl}]^{-}$típusú komplexek, ahol $(\mathrm{O}, \mathrm{X})$ egy ligandum, $\mathrm{X}$ pedig $\mathrm{O}$, N vagy $\mathrm{S}$. Az $(\mathrm{O}, \mathrm{O})$ kelátképző ligandumok komplexei csak mérsékelt citotoxikus hatást mutatnak, azonban a pikolinsav, de főleg az $(\mathrm{O}, \mathrm{S})$ típusú ligandumok komplexei különösen hatásosnak bizonyultak. ${ }^{143,144,145,146,147,148,149,150}$ A harmadik koordinációs helyet egy könnyen távozó csoportként kloridion foglalja el, ami oldatban részben vagy teljesen vízre cserélődhet (9. ábra).

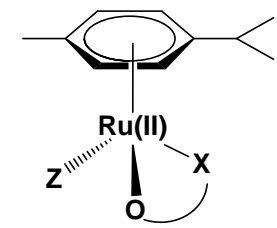

9. ábra: $\left[\mathrm{Ru}(\mathrm{II})-\eta^{6}-\mathrm{p}\right.$-cimol] monokomplexének feltételezett szerkezete $\left(\mathrm{X}=\mathrm{N}, \mathrm{O}\right.$,vagy $\mathrm{S} ; \mathrm{Z}=\mathrm{H}_{2} \mathrm{O}, \mathrm{Cl}^{-}$vagy $\left.\mathrm{OH}^{-}\right)$

Munkánk során a bécsi egyetemmel együttműködve a $\left[\mathrm{Ru}(\mathrm{II})-\eta^{6}-\mathrm{p}\right.$-cimol] vegyület vizes oldatbeli viselkedését, és komplexképző sajátságait vizsgáltuk részletesebben

- $(\mathrm{O}, \mathrm{O})$ donoratom tartalmú hidroxipiron-származékokkal - az allomaltollal és etilmaltollal,

- $(\mathrm{O}, \mathrm{N})$ donor ligandumokkal rendelkező pikolinsav (pik), 6-metil-pikolinsavval (6Mepik) és 2,6-dipikolinsavval (dipik),

- $(\mathrm{O}, \mathrm{S})$ donoratom tartalmú tioallomaltollal,

és próbáltunk következtetéseket levonni a komplexek stabilitása és rákellenes hatása között.

Mivel kloridion is koordinálódni képes a $\left[\mathrm{Ru}(\mathrm{II})-\eta^{6}-p\right.$-cimol] szabad koordinációs helyeire, így szerepét a komplexképződési folyamatokban nem lehet elhanyagolni. 
Kloridionos és kloridion-mentes közegben is végeztünk oldategyensúlyi méréseket, illetve vizsgáltuk a kloridion koncentráció változásának hatását a komplexképződésre.

$\left[\mathrm{Ru}(\mathrm{II})-\eta^{6}-p\right.$-cimol $]$ maga is egy fémorganikus komplex, amit szilárd $\left[\left\{\left(\eta^{6}-p-\right.\right.\right.$ cimol) $\mathrm{Ru}(\mu-\mathrm{Cl})\}_{2} \mathrm{Cl}_{2}$ ] dimer oldódásával nyerünk. Oldatkémiáját Buglyó Péter és munkatársai pH-potenciometriás, ${ }^{1} \mathrm{H}$ NMR, UV-látható és ESI-MS technikákkal részletesen tanulmányozták. ${ }^{136,166,181}$ Meghatározták, hogy kloridmentes, savas közegben (pH 4-ig) a fémorganikus [Ru(II)- $\eta^{6}-p$-cimol] akvakomplexe van jelen. Kloridmentes közegben a három szabad koordinációs helyet vízmolekulák foglalják el. A pH-t növelve kialakul a kétmagvú, három hidroxidohidas részecske, amely pH 6 körül dominánssá válik az oldatban. Kloridionos közegben azonban maga a kloridion is koordinálódni képes, így a koncentrációját növelve a koordinálódott vízmolekulák egyre inkább kloridionra cserélhetők. Megállapították, hogy a hidrolízis során a három hidroxidohidas szerkezeten túl hidroxido-klorido vegyeskomplexek is képződnek (10. ábra). A kloridionok (habár kis mértékben) de képesek visszaszorítani a hidrolízist.

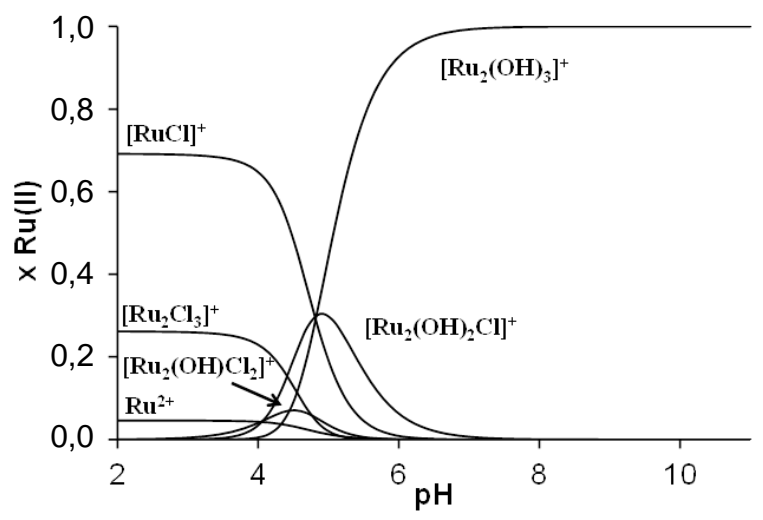

10. ábra: $\left[\mathrm{Ru}(\mathrm{II})-\eta^{6}-p\right.$-cimol] koncentrációeloszlási diagramja $0,2 \mathrm{M} \mathrm{KCl}$ tartalmú vizes oldatban. $\left(\mathrm{c}_{\mathrm{M}}=2 \times 10^{-3} \mathrm{M}, \mathrm{t}=25^{\circ} \mathrm{C}\right)^{166}$

Az oldatban azonosított komplexek összetétele, és azok meghatározott stabilitási állandói a 1. táblázatban, illetve a 10. és a 11. ábrán láthatók. A klorido-, és hidroxidokomplexekre meghatározott stabilitási állandók alapján az általunk általánosan használt 0,2 M KCl-os ionerősségű oldatban jelenlévő részecskék, és azok eloszlás diagramját a 14. ábrán mutatjuk be. 
1. táblázat: Kloridion-tartalmú vizes oldatban beazonosított $\left[\mathrm{Ru}(\mathrm{II})-\eta^{6}-p\right.$-cimol] komplexek összetétele és stabilitási szorzatai ${ }^{166}$

\begin{tabular}{|c|c|}
\hline Azonosított komplexek & $\lg \beta$ \\
\hline$\left[\mathrm{Ru}(\mathrm{II})-\eta^{6}-p-\operatorname{cimol}\left(\mathrm{H}_{2} \mathrm{O}\right)_{3}\right]^{2+}$ & - \\
\hline$\left[\mathrm{Ru}(\mathrm{II})-\eta^{6}-p-\operatorname{cimolCl}\left(\mathrm{H}_{2} \mathrm{O}\right)_{2}\right]^{+}$ & $\begin{array}{c}1,82(1)^{\mathrm{a}} \\
1,88(5)^{\mathrm{b}} \\
1,9(1)^{\mathrm{c}}\end{array}$ \\
\hline$\left[\left\{\operatorname{Ru}(\mathrm{II})-\eta^{6}-p-\operatorname{cimol}\right\}_{2}\left(\mu^{2}-\mathrm{Cl}\right)_{3}\right]^{+}$ & $\begin{array}{l}6,60(4)^{\mathrm{a}} \\
6,8(1)^{\mathrm{c}}\end{array}$ \\
\hline $\begin{array}{l}{\left[\left\{\operatorname{Ru}(\mathrm{II})-\eta^{6}-p-\operatorname{cimol}\right\}_{2}\left(\mu^{2}-\mathrm{OH}\right)\left(\mu^{2}-\right.\right.} \\
\left.\mathrm{Cl})_{2}\right]^{+}\end{array}$ & $1,14(6)^{\mathrm{a}}$ \\
\hline $\begin{array}{l}{\left[\left\{\mathrm{Ru}(\mathrm{II})-\eta^{6}-p-\operatorname{cimol}\right\}_{2}\left(\mu^{2}-\mathrm{OH}\right)_{2}\left(\mu^{2}-\right.\right.} \\
\mathrm{Cl})]^{+}\end{array}$ & $-3,63(2)^{\mathrm{a}}$ \\
\hline$\left[\left\{\operatorname{Ru}(\mathrm{II})-\eta^{6}-p-\operatorname{cimol}\right\}_{2}\left(\mu^{2}-\mathrm{OH}\right)_{3}\right]^{+}$ & $-9,16(1)^{\mathrm{a}}$ \\
\hline
\end{tabular}
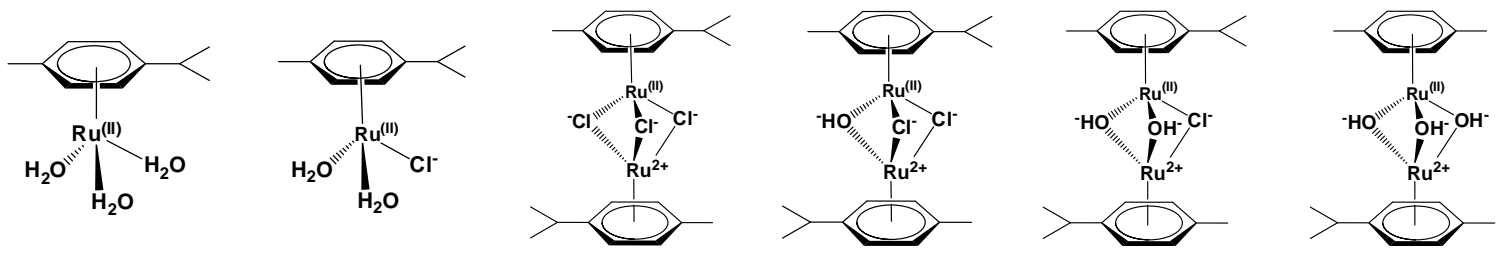

11. ábra: Kloridion-tartalmú vizes közegben jelenlévő, ill. megjelenhető [Ru(II)- $\eta^{6}-p$-cimol] komplexek szerkezeti képlete ${ }^{181}$

A Debreceni Tudományegyetem Bioszervetlen Kémiai Kutatócsoportjában a [Ru(II)- $\eta^{6}$ p-cimol] hidrolízisén túl vizsgálták a komplexképződést olyan $(\mathrm{O}, \mathrm{O})$ komplexképző ligandumokkal, melyek a vérszérumban megtalálhatóak, vagy rákellenes hatást mutatnak. Megállapították, hogy 1:1 arányú törzskomplexek képződnek, illetve a komplexképződést a donoratomok bázicitása nagymértékben befolyásolja. Azok a ligandumok, melyek kis bázicitású oxigén donoratomot tartalmaznak, már kis $\mathrm{pH}-\mathrm{n}$ is komplexet képesek kialakítani a [Ru(II)- $\eta^{6}-p$-cimol]-lal, azonban a hidrolízis folyamatok is kisebb pH-értéknél indulnak el, míg a nagyobb bázicitású ligandumok esetében mindezt fordítva tapasztalták. Az öttagú kelátgyürü kialakulásának lehetősége szintén a komplex stabilitásának növekedését eredményezte a hattagúval szemben. Az egyensúlyi folyamatok négy ligandum, a tiron, a deferipron, N-metil-acetohidroxámsav és a maltol esetében voltak követhetőek fiziológiás (7,4-es) pH-értékig. ${ }^{181}$

$\mathrm{Az}$ elmúlt évtizedben számos fémorganikus ruténium(II)- $\eta^{6}$-arén komplexet szintetizáltak, és in vitro vizsgálták biológiai aktivitásukat. [Ru(II)( $\eta^{6}-\mathrm{p}$-cimol $\left.)(X Y) C I\right]$ típusú vegyületekben $(\mathrm{XY})$ lehet $(\mathrm{O}, \mathrm{O}),(\mathrm{O}, \mathrm{S}),(\mathrm{O}, \mathrm{N}),(\mathrm{N}, \mathrm{N})$, vagy $(\mathrm{N}, \mathrm{S})$ típusú kétfogú ligandum, amely a koordinációs kötés erősségétől függően képes lehet megvédeni a Ru- 
cimolt a hidrolízistől. Kutatócsoportunkban főként olyan Ru(II)komplexek oldategyensúlyát tanulmányoztuk, melyek rákos sejtvonalakon biológiailag aktívak. A komplexek hatásmechanizmusának megértéséhez kulcsfontosságú az egyensúlyi kémiájuk ismerete, ezért oldategyensúlyi mérések segítségével próbáltunk következtetéseket levonni a biológiai hatás-szerkezet-stabilitás között. Az általunk vizsgált hidroxi-piron származékoknak, az allomaltolnak és az etil-maltolnak csak mérsékelt citotoxicitása van. Ennél jelentősebb a biológiai aktivitása a $(\mathrm{O}, \mathrm{N})$ donoratomos ligandumot (pl. pikolinsavat) tartalmazó komplexnek. Maga a pikolinsav önmagában nem citotoxikus, gyógyászati céllal több fémkomplexét is kipróbálták. Vanádium és cinkkomplexét, mint potenciális antidiabetikus hatású komplexet tesztelték már. ${ }^{151}$ Ivanović és munkatársai vizsgálták a pikolinsav Ru(II)-cimol komplexének biológiai aktivitását HeLa (human cervix carcinoma $=$ méhnyakrák) és FemX (melanoma) rákos sejtvonalakon. A meghatározott $\mathrm{IC}_{50}$ értékek (azaz az a koncentráció, melynél 50 százalékos sejthalál következik be) $\left(\mathrm{IC}_{50}=81,97 \mu \mathrm{M}\right.$ HeLa és 36,23 $\mu \mathrm{M}$ FemX sejtvonalon) közepes aktivitást mutatnak. ${ }^{153}$ Ugyanez a kutatócsoport vizsgálta $\left[\mathrm{Ru}(\mathrm{II})-\eta^{6}-p\right.$-cimol]-dipikolinát citotoxicitását is, azonban a komplex nem mutatott antiproliferatív hatást, a vizsgált sejteken a meghatározott $\mathrm{IC}_{50}$ érték több mint $300 \mu \mathrm{M}$-nak adódott. ${ }^{152}$ A 6-Mepik [Ru(II)- $\eta^{6}$ - $p$-cimol] biológiai aktivitásáról nincs adat az irodalomban. A rákellenes hatású $\left[\mathrm{Ru}(\mathrm{II})-\eta^{6}-\mathrm{p}\right.$-cimol]-pikolinsav és $(\mathrm{O}, \mathrm{S})$ donoratomos tiomaltol komplexeinek röntgenszerkezete is ismert (12. ábra). ${ }^{153}$
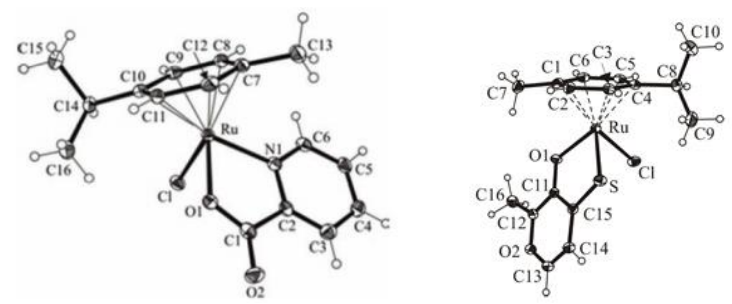

12. ábra: $\mathrm{Ru}(\mathrm{II})-\eta^{6}-p$-cimol-pikolinát és tiomaltolát komplexek röntgen diffrakciós szerkezete ${ }^{153,154}$

Keppler és munkatársai a maltol és allomaltol kénszármazékainak $\left[\mathrm{Ru}(\mathrm{II})\left(\eta^{6}-\mathrm{p}\right.\right.$ cimol)(O,S)CI] komplexeit állították elő, és tesztelték rákos sejtvonalakon, és megállapították, hogy egy nagyságrendnyi különbség mutatkozott a kén-koordinált, illetve csak oxigén donoratomot tartalmazó komplexek hatása között az tioszármazékok javára. ${ }^{143,144,154}$ A tiomaltollal és tioallomaltollal képződő komplexeik IC $_{50}$ értéke rákos sejtvonalakon $40 \mathrm{mM}$ alatti. ${ }^{144}$ 


\subsection{A speciáció alkalmazási lehetőségei a bioaktív fémvegyületek biológiájában}

A gyógyszerkutatás egy bonyolult, multidiszciplináris, költséges és hosszantartó folyamat. A kutatás-fejlesztés időtartama több mint tíz évre tehető, költsége egyes becslések szerint meghaladja az 1 millió USD-t. Ez az alfejezet arra keresi a választ, hol helyezkedik el ebben az évtizedes folyamatban az a munka, melyet a kutatócsoportunk végez. A gyógyszer fejlesztés első lépése minden esetben a tervezés. A további vizsgálatok sorrendje azonban sok esetben nézőpont kérdése. Jól tükrözi a két irányt dolgozatom két témája is. A Ru(II)alapú rákellenes szerek tanulmányozása esetén sok esetben olyan hatóanyagokat vizsgálunk, melyek biológiai aktivitása, citotoxicitása már korábbról ismert, kutatásaink során a szerkezet-biológiai hatás közötti összefüggésre próbálunk választ adni. Másik kutatási témánk, mely alkalmas kelátor molekulák kifejlesztésére irányul neurodegeneratív betegségek terápiájaként, másképp közelíti meg a célt. Ebben az esetben a szintézis után először a molekulák komplexképző sajátságainak vizsgálata történik. Arra keressük a választ, hogy a szintetizált molekula megfelel-e célunknak, elég erős kelátképző lehet-e a kérdéses fémionnal, alkalmas lehet-e arra, hogy a $\beta$-amiloid fehérje által megkötött fémionokat elvonja az így kialakult oligomer vagy aggregátum formákból, vagy a megváltozott fémion-homeosztázist képes-e befolyásolni. A biológiai vizsgálatok csak azután következnek, miután megbizonyosodtunk, arról, hogy a molekula megfelelő stabilitású komplexeket képez a kérdéses fémionokkal.

Az úttól függetlenül azonban ahhoz, hogy egy farmakonból végül gyógyszer molekula legyen, szükséges ismerni a hatóanyagot érintő főbb eseményeket a szervezetben, azaz összefoglaló nevén az ún. farmakokinetikát. Sok esetben ezeket a folyamatokat az ADME felosztás keretében tárgyalják, amely egy mozaik szó, és az egyes karakterek a következőket jelenik. ${ }^{155,156}$
A - Abszorbció - Felszívódás
D - Disztribúció - Eloszlás
M - Metabolizáció - Átalakulás
E - Elimináció - Kiválasztás

Kutatási feladatainknak több szinten is szerepe lehet a farmakokinetikai folyamatok tisztázásában. Az abszorpció folyamata azt jellemzi, hogyan kerül a gyógyszer a beadás helyéről a szisztémás vérkeringésbe. Alapvető fontosságú annak ismerete, hogy a kívánt hatóanyag, amely lehet maga a ligandum vagy a fémkomplex, milyen formában van jelen a a gyomor savas pH-ján, vagy az intravénás infúziós oldatban, és milyen formában van 
jelen a vérben. A kutatócsoport eredményei a témával kapcsolatban megkérdőjelezhetetlenek. Korábbi kutatások segítették tisztázni pl. a ligandumok szerepét inzulinutánzó vanádiumvegyületek esetében. A korábbi kutatások azt feltételezték, hogy a vanádiumkomplexek azok, melyek biológiai hatása eredményesebb az egyszerü vanádium(IV) hatásánál, azonban az oldategyensúlyi mérések tisztázták, hogy a ligandum a vanádium felszívódását segíti elő, később fiziológiás körülmények között $(\mathrm{pH}=7,4)$ a komplex disszociál, és a vérben való szállítódás során a komplex fémtartalma a szérumalkotókkal (elsősorban a transzferrinnel) lép kölcsönhatásba. ${ }^{157}$

A disztribúció folyamatának vizsgálata arra adhat választ, hogyan jut el a hatóanyag a támadáspontig. A gyógyszerek többsége vízoldékony vegyület, a plazmafehérjékhez általában reverzibilisen képes kötődni. Manapság igen népszerű elképzelés az, hogy több rákellenes fémkomplex ( $\mathrm{Ru}(\mathrm{III}), \mathrm{Ga}(\mathrm{III}))$ a vasszállító transzferrin fehérje segítségével juthat be a rákos sejtekbe. ${ }^{158} \mathrm{~A}$ tumorsejteknek intenzív anyagcseréjének következtében vas igényük megnő, ezért több transzferrint vesznek fel, így a transzferrinhez kötött rákellenes komplex képes felhalmozódni a sejtben. ${ }^{159,160}$

A humán szérum albumin molekula (HSA) a pufferelő, az ozmotikus nyomást fenntartó és az enzimatikus szerepén túl az endogén és exogén molekulák szállításában szintén fontos szerepet tölt be, igen sok és sokféle kötőhelyet tartalmaz. ${ }^{161}$ A többi plazmafehérje közül már jelentős mennyisége is kiemeli, a teljes szérum fehérje koncentráció (70 g/l) $60 \%$-át (35-50 g/1, 630 $\mu \mathrm{M})$ teszi ki. Egyetlen, 585 aminosavból álló egyszerű globuláris fehérje, amely szerkezetileg I-, II- és III-as egységre bontható. Ezeket két-két alegységre szokás tovább osztani, melyet IA, IIB stb. formában jelölnek (13. ábra). A molekula tizenhét diszulfidhidat, egy szulfhidril-csoportot, továbbá egyetlen triptofán aminosavat (Trp(214)) tartalmaz. A HSA számos kötőhellyel rendelkezik. A megkötött molekuláknak nagy hányadát teszik ki a zsírsavak, melyek kötésére megközelítőleg hat kötőhely áll rendelkezésre az albuminon. Találunk továbbá peptid hormonok, szteroidok, fémionok mint pl. $\mathrm{Ca}^{2+} \mathrm{Zn}^{2+}, \mathrm{Ni}^{2+}, \mathrm{Al}^{3+}, \mathrm{Cu}^{2+}$-ionok szállításáért felelős molekularészeket is.

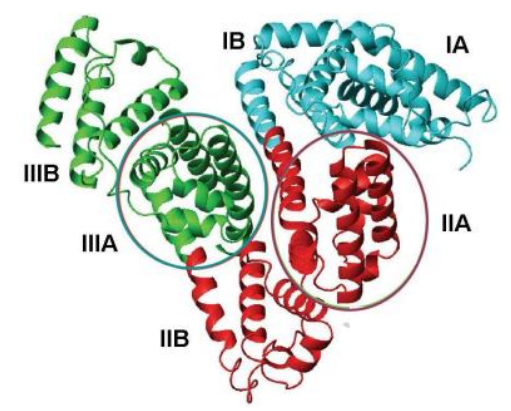

13. ábra: A humán szérum albumin háromdimenziós szerkezete 
Bár a sejtek nem rendelkeznek HSA receptorokkal, képes az érfalon átjutni. A rákos sejtek közelében az érfal penetráltsága fokozottabb, másrészt aktív transzporterek jelennek meg az érfalon, így jóval több albumin molekula kerül a rákos szövetbe. A plazmafehérjéken kötött gyógyszer frakció másrészt keringő „depónak” vagy „rezervoárnak” is tekinthetők, ezzel javítható az adott anyag oldhatósága, és késleltethető a metabolizmus. A metabolizmus fogalmán a farmakon átalakulását értjük a szervezetben (oxidáció, redukció, hidrolízis, konjugáció). Egyes gyógyszerek esetén ez a lépés kimarad, és változatlan formában ürülnek, választódnak ki a szervezetből.

A gyógyszerkutatásnak csak egy kis, bár kétségtelenül nagyon fontos részét képezi az előbb részletezett farmakokinetika tanulmányozása. Egy új gyógyszer forgalomba kerüléséig, ezek után még hosszú évek telnek el. ${ }^{162}$ A klinikai vizsgálatokban kutatócsoportunk már nem vesz részt. A biológiai vizsgálatokat is jórészt a kooperációs partnereink végzik el. Feladatunk, hogy megállapítsuk a lehetséges képződő komplexek összetételét és stabilitását, ezáltal jósolni tudjuk a fiziológiás körülmények között a legvalószínübb megjelenési komplex formákat. Következtetni tudunk a komplex szerkezete és biológiai aktivitása közötti kapcsolatra, ezáltal javaslatokat tudunk tenni sikeres, vezető fémkomplex kiválasztására, fejlesztési irányára, továbbá hozzá járulunk a hatásmechanizmus megértéséhez. Vizsgálni tudjuk a ligandumok, a fémionok és a komplexek kölcsönhatását a vér szérumfehérjéivel. A kötődés alapvetően befolyásolja a gyógyszer eloszlását, hatástartalmát, metabolizmusát, szervezetből való kiürülését, azaz a farmakokinetikáját. 


\section{Alkalmazott vizsgálati módszerek, kísérleti körülmények}

\subsection{Felhasznált anyagok}

A pikolinsavat (pik), 6-metil-pikolinsavat (6-Mepik), dipikolinsavat, (dipik), allomaltolt, etil-maltolt, human szérum albumint (HSA) (zsírsavat tartalmazó A1653), HEPES-t, $\mathrm{KCl}$-ot, $\mathrm{KNO}_{3}$-t, $\mathrm{AgNO}_{3}$-ot, $\mathrm{CuCl}_{2}$-ot, $\mathrm{ZnCl}_{2}$-ot $\mathrm{HCl}$-ot, $\mathrm{HNO}_{3}$-ot, $\mathrm{KOH}$-ot, $\mathrm{NaH}_{2} \mathrm{PO}_{4}$-ot, $\mathrm{Na}_{2} \mathrm{HPO}_{4}$-ot és NaCl-ot, $\mathrm{D}_{2} \mathrm{O}$-et $\left(99,9 \%\right.$ atom D), és a ${ }^{1} \mathrm{H}$ NMR méréseinkhez referenciakén használt $\mathrm{Me}_{3} \mathrm{SiCH}_{2} \mathrm{CH}_{2} \mathrm{COOH}$-ot a Sigma-Aldrichtől szereztük be. $\mathrm{Az}$ anyagokat további tisztítás nélkül használtuk fel. Az allomaltol és tioallomaltol ligandumok a kersekedelemben nem kaphatók, előállításuk irodalmi leírás alapján történt. ${ }^{163,164}$ A hidroxipiridinkarbonsav ligandumokat a Padovai Egyetem Kémiai Tudományok Tanszéke biztosította számunkra Valerio Di Marco közremüködésével. A ligandum oldatok pontos koncentrációját pH-potenciometriás mérésekkel határoztuk meg, a ligandumok protonálódási állandóját HYPERQUAD nevű programmal számoltuk. ${ }^{165} \mathrm{~A}$ karbonátmentesség érdekében nagy tisztaságú argongázt buborékoltattunk át az oldatokon. A titrálásokhoz ismert koncentrációjú $(0,2 \mathrm{M})$ karbonátmentes $\mathrm{KOH}$ oldatot használtunk. A $\left.\left[\mathrm{Ru}(\mathrm{II})-\eta^{6}-p \text {-cimolCl}\right]_{2}\right]_{2}$ komplexet Prof. Bernhard K. Keppler (Bécsi Egyetem, Szervetlen Kémiai Intézet) kutatócsoportjától kaptuk. A törzsoldatokat ismert mennyiségü $\left[R u(I I)-\eta^{6}-p\right.$-cimol] dimer vízben való feloldásával készítettük. A kloridmentesítés során ekvivalens mennyiségű $\mathrm{AgNO}_{3}$-ot adtunk az oldathoz, majd leszürtük, eltávolítva az oldatból a kivált $\mathrm{AgCl}$ csapadékot. $\mathrm{A}\left[\mathrm{Ru}(\mathrm{II})-\eta^{6}-p\right.$-cimol] oldatok pontos koncentrációját pH-potenciometria segítségével határoztuk meg alkalmazva a [Ru(II)- $\eta^{6}-p$-cimol]hidroxido komplexekre megadott irodalmi értékeket mind a kloridos, mind a kloridmentes közeg esetén. ${ }^{166,136}$ HSA oldatot minden mérés előtt frissen készítettünk, koncentrációját UV spektruma alapján határoztuk meg $\varepsilon_{280} \mathrm{~nm}(\mathrm{HSA})=36850 \mathrm{M}^{-1} \mathrm{~cm}^{-1}{ }^{167}$

\section{2. pH-potenciometria}

Az oldatfázisban végzett komplexkémiai vizsgálatok legáltalánosabb kísérleti módszere a pH-metria. A savi disszociációs $\left(K_{\mathrm{pqr}}\right)$ és komplexképződési $\left(\beta_{\mathrm{pqr}}\right)$ állandók meghatározása potenciometriás módszerrel történt. A módszer alkalmazhatóságának elvi háttere az, hogy a vizsgált folyamat során a fémionok leszorítják a ligandum protonjait, azaz a fémion és a $\mathrm{H}^{+}$a ligandum kötőhelyeiért versengenek. Ez az oldatbeli hidrogénion- 
koncentráció megváltozását okozza, mely az üvegelektród által érzékelt potenciálváltozást eredményez.

A potenciometriás mérések során az elektrolit oldatba merülő elektród felületén kialakuló elektródpotenciált mérjük. A Nernst-egyenlet teremt kapcsolatot a potenciál ( $\left.\mathrm{E}_{\text {elméleti }}\right)$, valamint az azt létrehozó elektródaktív komponens koncentrációja között, amely a pH-metriás mérések esetén nem más, mint a $\mathrm{H}^{+}$-ionok aktivitása:

$$
\mathrm{E}_{\text {elméleti }}=\mathrm{E}^{0}+(\mathrm{RT} / \mathrm{nF}) \times \ln \mathrm{a}\left(\mathrm{H}^{+}\right),
$$

ahol $\mathrm{E}^{0}$ a rendszer standardpotenciálja, $\mathrm{R}$ - az egyetemes gázállandó $(8,314 \mathrm{~J} / \mathrm{mol} \mathrm{K}), \mathrm{T}$ a hőmérséklet $(\mathrm{K}), \mathrm{n}$ az elektronszám változása az elektródfolyamatban, $\mathrm{F}$ a Faraday állandó (96485 C/mol).

Potenciometriás titrálások során a mérőoldat fogyásának függvényében mérjük az elektródpotenciál változását, melyet az alábbi egyenlet ír le:

$$
\mathrm{E}_{\mathrm{számolt}}=\mathrm{E}^{\prime}-\mathrm{m}_{\mathrm{E}} \times \mathrm{pH},
$$

ahol E' a formális standard elektródpotenciál, mely figyelembe veszi a referencia elektród potenciáját, a diffúziós potenciált és az oldat aktuális közepes aktivitási együtthatóját, $\mathrm{m}_{\mathrm{E}}$ az aktuális meredekség $\left(\mathrm{m}_{\mathrm{E}}=2,303 \times \mathrm{RT} / \mathrm{zF}\right)$.

Ilyen felfogásban a pH a hidrogénion egyensúlyi koncentrációjának 10-es alapú logaritmusának -1-szerese.

Annak érdekében, hogy a mért elektródpotenciálból pH-t tudjunk számolni, egy adott mérőrendszer esetén meg kell határozni a Nernst-egyenletben szereplö egyéb paramétereket, azaz a mérőrendszert kalibrálni kell. A mérőrendszer kalibrálása erős sav-erős bázis titrálással történt. A titrálási görbéket Gran-módszerrel értékeltük. ${ }^{168}$ A módszer alkalmas a titrált és titráló oldatok pontos koncentrációjának meghatározására minden olyan rendszerben, ahol érvényes a Nernst-egyenlet. A módszer alapja, hogy az egyes titrálási pontokban érvényes egyensúlyi koncentrációk kiszámításához használt összefüggéseket úgy transzformáljuk, hogy lineáris regresszióval kiszámítható legyen minden szükséges adat. $\mathrm{A} \mathrm{pH}_{\text {mért }}$ értékeket úgy alakítjuk át, hogy a transzformált adatokat a titráló oldat térfogatának függvényében ábrázolva az x-tengelyt az ekvivalencia pontban metsző egyenest kapjunk. Az oldatok koncentrációi és a fogyás ismeretében a pH számítható az erős sav-erős bázis titrálás minden olyan pontjában, ahol a víz öndisszociációja elhanyagolható és az erős sav még feleslegben van. Az így számított $\mathrm{pH}$ érték és a $\mathrm{pH}_{\text {mért }}$ érték azonban nem azonos, egy állandó értékkel - az Irving-fatkorral (IRV) - tér el egymástól. $^{169}$

$$
\mathrm{IRV}=\mathrm{pH}_{\text {mért }-\mathrm{pH}}
$$


Az ekvivalenciapont után a titrált és titráló oldatok pontos koncentrációiból az oldatok pOH értéke kiszámítható, valamint az Irving-faktorral korrigált pH értékek. Így a lúgos tartományban mért adatpárok alkalmasak a $\mathrm{pK}_{\mathrm{w}}$ számítására a következő képlet alapján:

$$
\mathrm{pK}_{\mathrm{w}}=-\lg \left(\left[\mathrm{H}^{+}\right] \times\left[\mathrm{OH}^{-}\right]\right)=\mathrm{p}\left[\mathrm{H}^{+}\right]+\mathrm{p}\left[\mathrm{OH}^{-}\right]=\left(\mathrm{pH}_{\text {mért }}-\mathrm{IRV}\right)-\lg \left[\mathrm{OH}^{-}\right]
$$

Ezek alapján a $\mathrm{H}^{+}$koncentrációjának méréséből következtetni lehet a képződő komplexek stabilitására. A komplexképződési kompetíciós reakció a következő általános egyenlettel írható le:

$$
\mathrm{qHA}+\mathrm{M}^{\mathrm{m}+} \rightleftharpoons \mathrm{MA}_{\mathrm{q}}^{(\mathrm{m}-\mathrm{q})+}+\mathrm{qH}^{+}
$$

A továbbiakban a töltéseket az egyszerübb áttekinthetőség érdekében elhanyagoljuk. Fémet $(\mathrm{M})$, teljesen deprotonált ligandumot $(\mathrm{L})$ és protont $(\mathrm{H})$ tartalmazó rendszerek esetében az egyensúlyi egyenletek a következőképpen írhatók fel:

$$
\mathrm{p} \mathrm{M}+\mathrm{qA}+\mathrm{rH} \rightleftharpoons \mathrm{M}_{\mathrm{p}} \mathrm{A}_{\mathrm{q}} \mathrm{H}_{\mathrm{r}}
$$

A fenti egyenletek alapján a képződő részecskék stabilitási szorzatát az alábbi összefüggéssel definiáljuk:

$$
\beta_{\mathrm{pqr}}=\frac{\left[\mathrm{M}_{\mathrm{p}} \mathrm{A}_{\mathrm{q}} \mathrm{H}_{\mathrm{r}}\right]}{[\mathrm{M}]^{\mathrm{p}}[\mathrm{A}]^{\mathrm{q}}[\mathrm{H}]^{\mathrm{r}}}
$$

A pH-metriás titrálási görbék felvétele azt jelentette, hogy a ligandum és a fémion oldatához kis részletekben lúgot adagoltunk és az egyensúly beállta után rögzítettük a térfogat-pH adatpárokat. A titrálási adatokból a stabilitási szorzatokat a PSEQUAD számítógépes programmal számítottuk ki. ${ }^{170} \mathrm{~A}$ számításokhoz, a komponensek teljes koncentrációját, a titrálási adatokat, az komponensek és az asszociátumok és az ismert stabilitási szorzatokat adtuk meg. A keresett stabilitási szorzatokat a reaktánsokra felírt anyagmérlegeket jelentő következő egyenletrendszer megoldása adja:

$$
\begin{aligned}
& c_{M}=[M]+\sum_{i=1}^{n} p_{i} \beta_{p_{i} q_{i} r_{i}}[M]^{p_{i}}[L]^{q_{i}}[H]^{r_{i}} \\
& c_{L}=[L]+\sum_{i=1}^{n} q_{i} \beta_{p_{i} q_{i} r_{i}}[M]^{p_{i}}[L]^{q_{i}}[H]^{r_{i}} \\
& c_{H}=[H]+\sum_{i=1}^{n} r_{i} \beta_{p_{i} q_{i_{i}}}[M]^{p_{i}}[L]^{q_{i}}[H]^{r_{i}}
\end{aligned}
$$

ahol $\mathrm{n}$ a rendszerben képződő asszociátumok számát, p,q,r, a sztöchiometriai együtthatókat jelöli.

A program az általunk feltételezett asszociátumok és közelítő stabilitási szorzatuk figyelembevételével, Newton-Raphson iterációval végzi a közelítést addig, míg a titráló oldatra nézve a $\Sigma\left(\mathrm{V}_{\text {mért }}-\mathrm{V}_{\text {számított }}\right)^{2}$ értéke minimumot ad ( $\mathrm{V}$ a titráló mérőoldat térfogata). A 
program minden megadott pH-értéknél kiszámolja az összes képződő részecske egyensúlyi koncentrációját és az adott pontokhoz tartozó standard deviáció értékét. Az iteráció végén megadja a finomított stabilitási szorzatokat, azok hibáját (a kvantitatív eredmények közlésekor a zárójelben szereplő szám a közölt érték utolsó számjegyét terhelő hibát jelenti), a kísérleti és a számított titrálási görbék pontjaihoz tartozó $\left(\mathrm{V}_{\text {mért }}-\mathrm{V}_{\text {számított }}\right)$ négyzet átlagának négyzetgyökét (ezt nevezzük illesztési paraméternek), és egy adott komponensre vonatkozóan kirajzolja az asszociátumok koncentráció-eloszlási görbéjét a $\mathrm{pH}$ függvényében. A feltételezett asszociátumok egy adott összességét nevezzük a rendszer modelljének. Azt a modellt tekintjük a rendszert leírónak, amely kémiai megfontolások alapján értelmezhető, és amelynél az illesztési paraméter a legkisebb. A pH-metria által szolgáltatott információk alapvető fontosságúak a komplexkémiai vizsgálatokban, de sok esetben nem lehet csak ez alapján egyértelmü következtetéseket levonni. Vannak olyan esetek például, amikor csak pH-metriával nem lehet különbséget tenni két részecske között, mert a képződésük azonos pH-effektussal jár, vagy nincs pH-effektus. Előfordulhat az is, hogy ugyanaz a rendszer kettő vagy több kémiailag reális modellel is gyakorlatilag egyformán jól leírható. Ilyen esetekben és általában a pH-metriás méréseink eredményeinek a megerősítésére más vizsgálati módszereket is alkalmazni kell.

A pH-potenciometriás méréseket $25^{\circ} \mathrm{C}$-on, $0,2 \mathrm{M}$ ionerősségnél $\left(\mathrm{KCl}\right.$ vagy $\left.\mathrm{KNO}_{3}\right)$ hajtottuk végbe minden esetben. Az inert atmoszférát, amely a lúgos közegben a levegő oxigén és szén-dioxid tartalmát távol tartotta, a titráló oldaton argon gáz átbuborékoltatásával biztosítottuk. A kiindulási térfogat általában $10 \mathrm{~cm}^{3}$ volt. A pH mérésre kombinált (6.0234.100 típusú) Metrohm elektródot alkalmaztunk Metrohm 713 pH-mérő berendezéshez csatlakoztatva. A titrálásokhoz $0,2 \mathrm{M} \mathrm{KOH}$ karbonátmentes mérőoldatot készítettünk, melyet Metrohm 665 Dosimat bürettával adagoltunk. A mérőoldat pontos koncentrációját káliumhidrogénftalát pontos beméréssel készített $0,05 \mathrm{M}$ oldat segítségével határoztuk meg. Ez utóbbit használtuk a pH-mérő beállítása is $(\mathrm{pH}=4,008)$. A titrálások során számítógép vezérelte automatikusan mind a lúg adagolását, mind a $\mathrm{pH}$ olvasását és rögzítését. 


\subsection{Spektrális módszerek}

\subsubsection{UV-látható spektrofotometria}

Spektrofotometriásan mérhetők azok az anyagok, amelyek az adott spektrumtartományban fényt nyelnek el, tehát kromofórokat tartalmaznak. Az UV (200$400 \mathrm{~nm}$ ) és a látható fény (400-800 nm) tartományában a fényabszorpció a molekula vagy az atom elektroneloszlását változtatja meg. Az elektronok a gerjesztés hatására a kisebb energiájú elektronpályákról a nagyobb energiájúakra kerülnek. Az UV-látható színképtartomány abszorpciós sávjai nagyon szélesek, ezért minőségi analitikai alkalmazásuk korlátozott, viszont a kvantitatív analitika egyik legszélesebb körben használt módszere. A koncentrációmérés alapjául a Lambert-Beer törvény szolgál:

$$
\mathrm{A}=\varepsilon \times \mathrm{c} \times 1,
$$

ahol, A a mért abszorbancia; $\varepsilon$ : moláris abszorbancia $\left[\mathrm{dm}^{3} \mathrm{~mol}^{-1} \mathrm{~cm}^{-1}\right], 1$ az úthossz $[\mathrm{cm}], \mathrm{c} \mathrm{a}$ koncentráció $[\mathrm{M}]$.

A számítás az adott rendszerbeli valamennyi komponensre felírható anyagmérleg egyenletek és az általánosított Lambert-Beer törvény alapján az abszorbanciára felírható egyenlet megoldásával történik:

$$
\mathrm{A}_{\lambda}=\log \left(\frac{\mathrm{I}}{\mathrm{I}_{0}}\right)=d \sum_{j=1}^{n} \varepsilon_{j \lambda} \beta_{j}\left[k_{l}\right]^{\alpha j_{l}} \ldots\left[k_{n}\right]^{\alpha j_{n}},
$$

ahol $A_{\lambda}$ a $\lambda$-val jelölt hullámhossznál mért abszorbancia, $d$ a fény úthossza a mintában, $n$ az adott hullámhosszon fényelnyelést mutató részecskék száma, $\varepsilon_{\mathrm{j} \lambda}$ a j-edik részecske moláris abszorbanciája a $\lambda$-val jelölt hullámhossznál, $\beta_{\mathrm{j}}$ a j-edik részecske stabilitási szorzata és $\mathrm{k}_{1} \ldots \mathrm{k}_{\mathrm{n}}$ a rendszerbeli komponensek.

Stabilitási állandó meghatározásához legtöbb esetben az UV-tartományban megjelenő ligandumsáv $\mathrm{pH}$-függő változása szolgált, de a színes [Ru(II)- $\eta^{6}-p$-cimol] komplexek esetében lehetőség van a töltésátviteli (CT) sávok változásának vizsgálatára is. Elvileg a réz(II)komplexek látható tartománybeli d-d átmenete is vizsgálható, azonban a hidroxipiridinkarbonsav ligandumok korlátozott oldhatósága miatt ezek olyan kis intenzitásúnak bizonyultak, hogy kiértékelésük nem volt lehetséges. A stabilitási szorzatokat a PSEQUAD számítógépes programmal számítottuk ki. ${ }^{170}$

A kiértékelésre használt PSEQUAD program ${ }^{170}$ több szempontból is elönyös számunkra: teljes spektrumok analízisére alkalmas, illetve több komponens abszorbanciáját is képes egyszerre kezelni. A program a következő adatok alapján számol: az 
egyedi mintáknál nyert abszorbancia értékek, a mintában található komponensek koncentrációja, a rendszerben megtalálható komponensek és asszociátumok megadása, az abszorbeáló vegyületek megjelölése, a képződő asszociátumok közelítő stabilitási állandói. A program az adatsorokból a pH-potenciometriánál leírt anyagmérlegek egyenletek alkalmas matematikai módszerrel való megoldásával számítja a keresett kötési állandókat, azok szórását és a fényelnyelő komponensek „,egyedi spektrumát”.

A spektrofotometriás méréseket $25,0 \pm 0,2{ }^{\circ} \mathrm{C}$-on, állandó ionerősség mellett $(0,2 \mathrm{M}$ $\mathrm{KCl}$ vagy $\mathrm{KNO}_{3}$ ) és $200-820 \mathrm{~nm}$ hullámhossztartományban végeztük egy HewlettPackard 8452A diódasoros spektrofotométeren. A küvetta úthossza $1 \mathrm{~cm}$ volt. A karbonátmentesség érdekében nagy tisztaságú argongázt buborékoltattunk át az oldatokon. A titrálásokhoz ismert koncentrációjú $(0,2 \mathrm{M})$, karbonátmentes $\mathrm{KOH}$ oldatot használtunk.

A spektrofotometriás titrálásokat különbözö összetételü, csak ligandumot vagy [Ru(II)$\eta^{6}$-p-cimol]-t illetve különböző fémion-ligandum arányt tartalmazó minták esetén végeztünk. Az esetek többségében állandó fémion-ligandum arányok mellett az elektrongerjesztési spektrumok pH-függését vizsgáltuk $\mathrm{pH}$ 2-12 tartományban. $\mathrm{pH} 2$ alatti méréseknél egyedi mintákat készítettünk 0,2 M ionerősség mellett. Az egyedi mintákban 1:1 fémion-ligandum arány mellett a $\mathrm{KCl}\left(\right.$ ill. $\mathrm{KNO}_{3}$ ) tartalmat fokozatosan $\mathrm{HCl}$-ra (ill. $\mathrm{HNO}_{3}$-ra) cserélve változtattuk a $\mathrm{pH}$-t, amelynek értékét az egyedi minták erős sav tartalma alapján számoltuk. [Ru(II)- $\eta^{6}-p$-cimol]-tioallomaltol rendszer esetén pH 9-nél vizsgáltuk a spektrumok változását változó fémion-ligandum arány mellett. Az alkalmazott pontos koncentráció és fémion-ligandum arányok az adott rendszereket tárgyaló alfejezetekben vannak feltüntetve.

\subsection{2. ${ }^{1} \mathrm{H}$ NMR spektroszkópia}

Az NMR spektroszkópia az egyik leghatékonyabb szerkezetvizsgáló módszer, mellyel a mágneses atommagok azonosíthatók. A módszer a zérustól eltérő magspinnel rendelkező elemek, illetve vegyületek azonosítására alkalmazható. Az eljárás a mágneses mag és a külső mágneses tér közötti kölcsönhatáson alapul. A magok mágneses momentuma a külső mágneses tér irányába áll be, és mint tengely körül kering. A külső mágneses tér hatására a mag energiája 2I+1 energianívóra hasad fel, amelyek közötti energiakülönbség arányosan nő a külső mágneses térrel. Az energianívók között megfelelő mágneses sugárzással átmenetek hozhatók létre. Az átmenet létrejöttéhez adott frekvenciájú sugárzás szükséges. Ennek következtében az eljárásnak rezonancia jellege van. Az atommagot körülvevő 
elektronfelhőben a külső mágneses tér diamágnességet indukál, amely megváltoztatja a külső mágneses tér értékét a mag helyén, ezáltal árnyékoló hatást fejt ki. Ez minden atomnál más és más rezonanciafrekvenciánál jelenik meg. A kémiai környezet ilyen jellegü befolyásoló hatását kémiai eltolódásnak $(\delta)$ nevezzük. A kémiai eltolódás információt ad a kémiai szerkezetröl. A kémiai eltolódáson a mag saját rezonanciafrekvenciája és egy referenciaként választott anyag (pl. tetrametil-szilán (TMS) vagy 4,4-dimetil-4szilapentán-1-szulfonsav (DSS)) rezonanciafrekvenciájának a különbségét értjük. A jelek intenzitása arányos az értük felelős magok számával, tehát meghatározható a különböző kémiai környezetben előforduló azonos magok relatív száma is. A szomszédos magok spinjei kölcsönhatnak egymással, melynek következtében az egyes magok jelei felhasadnak. A jelfelhasadás miatt a mag NMR jele nem egy szingulett, hanem egy jelcsoport, valamilyen multiplett lesz. A multiplett jelei közti távolságot, Hz-ben kifejezve, csatolási állandónak nevezzük.

$\mathrm{Az}{ }^{1} \mathrm{H}$ NMR spektroszkópiában a diamágneses árnyékolás dominál, ezért a szénhez kötött, nem cserélődő hidrogének kémiai eltolódása általában jó indikátora az ionizációval kapcsolatos elektronsürüség-változásnak.

Oldategyensúlyi, illetve stabilitási állandó meghatározási lehetőségeket tekintve megállapítható, hogy az NMR technikáknál alapvetően két eset különböztethető meg:

(a) a lassú csere esete, amikor a különböző részecskék jelei az NMR spektrumban elkülönülve jelennek meg. Ekkor a megfelelő jelek alatti területarányok azonosak a részecskék koncentrációarányaival. Ez alapján egyensúlyi koncentrációk, illetve stabilitási állandók számíthatók.

(b) Gyors csere esetében az adott NMR-aktív magot tartalmazó különböző részecskékhez a spektrumban egyetlen jel tartozik, melynek kémiai eltolódás (vagy relaxációs idő) értéke az adott NMR-aktív magot tartalmazó részecskék kémiai eltolódásának (relaxációs idejének) móltört szerinti súlyozott átlaga.

Protonálódási állandó $(\mathrm{K})$ számítása:

$$
v_{\text {mért }}=x_{H L} v_{H L}+x_{L} v_{L}
$$

illetve a

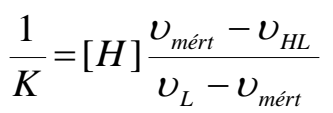

egyenletek alapján történt, ahol $v_{\text {mért }}$ a mért kémiai eltolódás értéke, $v_{\mathrm{HL}}$ a protonált részecske kémiai eltolódás értéke, $v_{\mathrm{L}}$ a deprotonált részecske kémiai eltolódás értéke, $\mathrm{x}_{\mathrm{HL}}$, illetve $\mathrm{x}_{\mathrm{L}}$ a HL és az L részecskék móltörtje. 
A ${ }^{1}$ H-NMR méréseket Bruker Ultrashield 500 Plus típusú készülékkel végeztük, a spektrumok kiértékeléséhez pedig a MNova (MestRe-C Lab) programot használtunk. A kémiai eltolódásokat ppm értékben kifejezve belső standard jeléhez viszonyítva adtuk meg. Referenciaanyagként 4,4-dimetil-4-szilapentán-1-szulfonsavat (DSS) alkalmaztunk. A minták elkészítéséhez oldószerként $10 \%(\mathrm{v} / \mathrm{v}) \mathrm{D}_{2} \mathrm{O} / \mathrm{H}_{2} \mathrm{O}$ elegyet használtunk. A mintákban lévő ligandumkoncentráció általában 1 vagy $2 \mathrm{mM}$ volt, a titrálást ismert koncentrációjú $\mathrm{KOH}$ oldattal végeztük $0,20 \mathrm{M}$-os ionerősség $\left(\mathrm{KCl}\right.$ vagy $\left.\mathrm{KNO}_{3}\right)$ mellett. A ligandumokat és a $\left[\left(\mathrm{Ru}(\mathrm{II})-\eta^{6}\right.\right.$-p-cimol] komplexet először önmagában, majd változó fémion-ligandum arány $\left(\mathrm{M}: \mathrm{L}=1: 1\right.$ és 1:2) mellett titráltuk. A [(Ru(II)- $\eta^{6}-p$-cimol(L)X] komplexek harmadik koordinációs helyén történő $\mathrm{H}_{2} \mathrm{O} / \mathrm{Cl}^{-}$cserefolyamatot állandó $\mathrm{pH}-n$ változó kloridionkoncentráció (0-500 mM) mellett vizsgáltuk.

\subsubsection{ESR spektroszkópia}

$\mathrm{Az}$ elektronspinrezonancia-spektroszkópia a paramágneses anyagok vizsgálatára szolgáló módszer. A mágnese tér és a párosítatlan elektron között kölcsönhatás alakul ki, amit Zeeman-effektusnak neveznek A mágneses tér irányára merőlegesen polarizált elektromágneses sugárzás átmenetet hozhat létre két szomszédos energiaszint között, ha teljesül a rezonanciafeltétel, amely szerint az elektromágneses sugárzás fotonjának energiája megegyezik a szomszédos energiaszintek különbségével:

$$
\Delta \mathrm{E}=\mathrm{h} \times \mathrm{v}=\mathrm{g} \times \mu_{\mathrm{B}} \times \mathrm{B} .
$$

Az átmenet függ a $v$ frekvenciától, a B indukciótól és a g-tényezőtől, amelyet a vizsgált molekula sajátságai határoznak meg; $\mu_{\mathrm{B}}$ a Bohr-magneton, h a Planck-állandó.

Az ESR-spektrum felvételekor állandó frekvencia mellett változtatják az indukciót, amíg be nem következik a sugárzás abszorpciója, az ún. rezonancia-abszorpció. A mérés során kapott görbe a fényintenzitás mágneses indukció szerinti első deriváltja a mágneses indukció függvényében. Folyékony fázisban ezt többnyire a Lorentz-görbe, míg szilárd fázisban gyakran a Gauss-görbe írja le.

A spinmomentum mellett a pályaimpulzus-momentum is hozzájárul az atomok, molekulák mágneses momentumához. Ez bizonyos átmenetifémek esetében, pl. a réz(II)komplexekben is nagymértékü lehet, ami az ESR-spektrumokban a g-nek a $\mathrm{g}_{\mathrm{e}}=2,0023$ szabad elektron g-értéktől való eltérésében mutatkozik meg. Ez az eltérés a molekula különböző irányaiban eltérő mértékủ lehet, vagyis a g anizotróp. ${ }^{171}$ A g szögfüggéséből 
meghatározható egy 3x3-as szimmetrikus mátrix (g-tenzor), ezt diagonizálva a fóátló elemeiből megkapjuk a g-tenzor fóértékeit.

A molekulák szimmetriája meghatározza a g-tenzor jellegét. Köbös szimmetriánál izotróp a g-tenzor, vagyis mindhárom fóértéke megegyezik. Tetragonális szimmetriánál a mágneses tér irányára merőleges fóértékek megegyeznek, míg a párhuzamos eltér ezektől: a g-tenzor axiális. Ennél alacsonyabb szimmetria esetén mindhárom fóérték eltér egymástól, a g-tenzor rombos. Ugyanilyen összefüggés érvényesül a szimmetria és az A hiperfinomcsatolási tenzor (az elektron és a fémion mágneses magja között létrejött kölcsönhatást leíró kölcsönhatási mátrix), az a szuperhiperfinomcsatolási tenzor (a párosítatlan elektron és a mágneses ligandummagok kölcsönhatásából származó mátrix), továbbá, ha a molekulában több párosítatlan elektron van, a D zérustér - felhasadási tenzor esetében is. ${ }^{171}$

A vonalszélesség is tenzormennyiség, és egy-egy föirányban a különböző hiperfinomvonalak esetében is eltérő. Nagyon gyakran érvényes a következő összefüggés:

$$
\mathrm{W}_{\mathrm{MI}}=\alpha+\beta \mathrm{M}_{\mathrm{I}}+\gamma \mathrm{M}_{\mathrm{I}}^{2},
$$

ahol $\alpha, \beta, \gamma$ a tér dimenziójú, anizotróp relaxációs paraméterek és $M_{I}$ pedig a központi fémion mag mágneses kvantumszáma. ${ }^{172}$

\subsubsection{ESR spektrumok szilárd fázisban}

Egykristályban a molekulák orientációja megegyezik, ezért közvetlenül mérhető, hogy a paraméterek szögfüggése miatt hogyan változik a színkép. Polikristályos mintákban és megfagyasztott oldatokban a különböző részecskék orientációja a térhez képest eltérő, de helyzetük a mérés során állandó, így a színkép a különböző orientációjú molekulák spektrumainak összege, ezért itt is megjelenik a paraméterek szögfüggése.

A tetragonális komplexekben szokásos koordinátarendszer-választás szerint a tetragonális tengely a z-tengely, ez jelöli ki az ún. „párhuzamos” föirányt, ugyanis a mágneses indukció irányát a z-tengellyel bezárt szögével, a $\Theta$-val szokás megadni. A tenzorok „párhuzamos” irányban mérhető fóértékeit a párhuzamos jel $(\|)$, míg $\Theta=90^{\circ}$ irányában mérhetőeket a merőleges jel $(\perp)$ indexszel jelöljük. Axiális szimmetria esetén tehát $g_{\|} \equiv g_{z z}$ és $\mathrm{g} \perp=\mathrm{g}_{\mathrm{xx}}=\mathrm{g}_{\mathrm{yy}}{ }^{171} \mathrm{Az}$ ESR spektrumokat az MTA Molekuláris Farmakológiai Intézet ESR laboratóriumában vettük fel BRUKER EleXsys E500 spektrométeren. 


\subsubsection{ESR spektrumok folyadék fázisban}

Folyékony oldatban a rendezetlen orientációjú molekulák állandóan változtatják a helyzetüket. Ha forgásuk elég gyors, a paraméterek szögfüggése kiátlagolódik. Az ilyen, ún. izotróp spektrumokból a kölcsönhatási tenzorok főértékeinek átlaga határozható meg (pl.: $\mathrm{g}_{0}=1 / 3\left(\mathrm{~g}_{\mathrm{xx}}+\mathrm{g}_{\mathrm{yy}}+\mathrm{g}_{\mathrm{zz}}\right){ }^{171}$ Az egyes spektrumokat leíró kevesebb paraméter lehetővé teszi egy ún. izotróp spektrum matematikai felbontását több komponens görbére, illetve bonyolultabb komplex egyensúlyi rendszerek spektrumsorozatainak ún. kétdimenziós értékelését.

\subsubsection{ESR spektrumok kiértékelése}

Folyadék fázisban a 2D_EPR programot ${ }^{173}$ használtuk a spektrumok értékeléséhez. Az értékelés azon a gyakorlat által igazolt feltételezésen alapul, hogy az ESR-átmenethez viszonyítva az egyes komplexek egymásba alakulása lassú, ezért a kísérleti görbe az oldatban jelen lévő komplexek spektrumainak koncentrációikkal súlyozott összege. A 2D_EPR program, amely 15 ESR-aktív és 5 inaktív molekulafajtát, 132 paramétert tud egyszerre kezelni, a paramágneses komplex egyensúlyi rendszerekben különböző körülmények között felvett spektrumok együttes kiértékelését végzi el. A spektrumfelvétel körülményeinek alkalmas megválasztásával - a rendszer egyensúlyi eloszlásának figyelembevételével - kell biztosítani, hogy valamennyi komplex, a kisebb stabilitásúak is, minél nagyobb koncentrációban képződjenek. Így érhető el, hogy spektrumaik, mint komponensgörbék megfelelő arányban megjelenjenek a kísérleti görbék egy-egy csoportjában, és elegendő információt kapjunk mindegyik molekulafajtáról a rendszerben. ${ }^{173}$

A program nevében a 2D a kétdimenziós szót jelöli, ami azt fejezi ki, hogy a teljes görbesorozat egyidejü értékelésével vizsgáljuk a jelintenzitás tér- és koncentrációfüggését. A program optimalizálja az egyes molekulafajták ESR-paramétereit: a $\mathrm{g}_{0}$ értéket, az $\mathrm{A}_{0}$ hiperfinom- és $a_{\mathrm{N} 0}$ szuperhiperfinom-csatolási állandókat és a $W_{M I}$ vonalszélességet meghatározó $\alpha, \beta, \gamma$ relaxációs paramétereket, valamint az ESR-aktív molekulák képződési állandóit (amelyeket szintén $\beta$-val jelölnek, és értékük tízes alapú logaritmusát szokás megadni a szakirodalomban). Ha a következő

$$
\mathrm{p} \mathrm{Cu}+\mathrm{q} \mathrm{L}+\mathrm{rH} \rightleftharpoons \mathrm{Cu}_{\mathrm{p}} \mathrm{L}_{\mathrm{q}} \mathrm{H}_{\mathrm{r}}
$$


általános komplexképződési folyamat megy végbe, akkor a folyamatra vonatkozó egyensúlyi állandó a képződési állandó

$$
\beta=\left[\mathrm{Cu}_{\mathrm{p}} \mathrm{L}_{\mathrm{q}} \mathrm{H}_{\mathrm{r}}\right] /\left([\mathrm{Cu}]^{\mathrm{p}} \cdot[\mathrm{L}]^{\mathrm{q}} \cdot[\mathrm{H}]^{\mathrm{r}}\right) .
$$

A program valamennyi komplex ESR-paramétereinek és képződési állandójának értékeit változtatja addig, amíg a teljes spektrumsorozatra vonatkozó SSQD (teljes átlagos négyzetes eltérés) - az egyedi színképekre vonatkozó SQD átlagos négyzetes eltérés értékek összege - már nem csökken tovább. A 2D_EPR program az SSQD értékből számítja az R teljes regressziós együttható értékét úgy, hogy az átlagos zajnégyzetet is figyelembe veszi. Ezzel jellemezzük a teljes spektrumsorozatra vonatkozó színképi egyezést. Az egyes színképeknél a mért és számított görbék egyezését az $R_{j}$ egyedi regressziós együtthatóval adjuk meg, amelyet a program az SQD-ből az adott spektrumra jellemző átlagos zajnégyzet figyelembevételével számol ki.

A megfagyasztott oldatban felvett anizotróp spektrumok értékelésére az EPR programot $^{174}$ használtunk, amely a $\mathrm{g}$, A és $\mathrm{P}$ (kvadrupólus felhasadási), valamint a vonalszélességi tenzorok föértékeit illeszti, utóbbiakat az $\alpha, \beta, \gamma$ relaxációs paraméterek felhasználásával. Az összetevő spektrumok arányát is úgy változtatja, hogy az SQD és $R_{j}$ értékek minél kisebbek legyenek.

\subsubsection{Spektrofluorimetria}

A spektrofluorimetria napjaink közkedvelt vizsgálati módszere. Népszerűségét elsősorban kis anyagigényének (kis térfogat, $\mu \mathrm{M}$-os koncentráció) köszönheti. Többek között fehérjék, valamint fehérjékkel kölcsönható vegyületek vizsgálatára alkalmazható. Nagy hátránya azonban, hogy a mért intenzitásváltozásokból csak közvetve következtethetünk a kötődés helyére. A módszer azon alapszik, hogy bizonyos vegyületek az UV-látható sugárzás abszorpciója következtében fotolumineszcenciát mutatnak, azaz fényt emittálnak. Amennyiben a fény kisugárzása a gerjesztés után $10^{-4}$ másodpercnél rövidebb idő alatt következik be, fluoreszcens fényről beszélünk. A fehérjékben három olyan aminosav található, amely aromás szerkezete miatt fluoreszcens: a fenilalanin (Phe), tirozin (Tyr) és a triptofán (Trp). ${ }^{175}$ A HSA-ban egyetlen Trp található a 214-es helyzetben. Amennyiben csak ezt az aminosavat akarjuk gerjeszteni a fehérjében, úgy a besugárzó fény hullámhosszát $\lambda_{\mathrm{EX}}=295 \mathrm{~nm}$-nek választjuk. A Trp(214) a IIA domén „hidrofób zsebe” közelében helyezkedik el. Tehát, ha az I-es kötöhelyhez beköt egy vagy több vegyület (ligandum), akkor ott megváltoznak a hidrofób-hidrofil viszonyok, ami hatással van a Trp 
emissziójának intenzitására. Az ilyen típusú vizsgálatok az ún. „kioltás” (kvencselés, angolul quenching) jelenségén alapulnak: a HSA kezdeti emissziós intenzitása valamely vegyület hozzáadásával folyamatosan csökken. A fluoreszcenciás intenzitás változását a ligandum vagy a komplex oldaláról is követni lehet, ha találunk olyan a ligandumra jellemző gerjesztési hullámhosszat. A változások mértékéből pedig a fehérje-ligandum kölcsönhatásról, annak erősségéről nyerhetünk információt.

A spektrofluorimetriás méréseket igen híg oldatban végezzük ( $\mu \mathrm{M}$-os koncentráció) a jelentős önabszorpció elkerülése miatt. Az alacsony koncentráció a disszociációnak kedvez, ebből következik, hogy fluorimetriás mérések alapján elsősorban az 1:1 arányú komplexekre lehet kötési állandókat meghatározni.

A fluorimetriás spektrumokat Hitachi-F4500 típusú spektrofluoriméterrel vettük fel $25 \pm 0,1^{\circ} \mathrm{C}$-on $1 \mathrm{~cm}$-es úthosszú kvarc küvettát használva. A pH állandó értéken tartása érdekében DQ5 és DQ715, illetve [Ru(II)- $\eta^{6}-p$-cimol] és komplexeinek albuminkötő képességének vizsgálatakor az összes mintát $15 \mathrm{mM}$ foszfát pufferben készítettük el $100,5 \mathrm{mM} \mathrm{NaCl}$ és $1,5 \mathrm{mM} \mathrm{KCl}$ jelenlétében. (Így biztosítottuk a vérnek megfelelő $\mathrm{pH}-\mathrm{t}$, a kloridion-koncentrációt és közelítőleg a $\mathrm{Na}^{+} / \mathrm{K}^{+}$arányt.) DT726 ligandum esetében HEPES puffert alkalmaztunk. A gerjesztő hullámhossz $\left(\lambda_{\mathrm{EX}}\right) 280 \mathrm{~nm}$ (Tyr) és $295 \mathrm{~nm}$ (Trp) volt, az emissziós spektrumokat a ( $\left.\lambda_{\mathrm{EM}}\right) 310-650 \mathrm{~nm}$-es tartományban mértük $10 \mathrm{~nm} / 5 \mathrm{~nm}$ vagy 5 $\mathrm{nm} / 5 \mathrm{~nm}$-es monokromátor résszélesség mellett. A fluorimetriásan mért minták UV-látható spektrumait is felvettük, melyek segítségével minden esetben megállapítható volt, hogy a minták önabszorpciója elhanyagolható (Abszorbancia $<0,02$ mind a $\lambda_{\mathrm{EX}}$, mind a $\lambda_{\mathrm{EM}}$ hullámhosszán), így az azzal való korrekció nem szükséges.

A kiértékelésre a PSEQUAD programot ${ }^{170}$ használtuk. A számolás elméleti háttere az UV-látható spektrofotometriás mérések kiértékeléséhez hasonló, azzal a különbséggel, hogy itt az abszorbancia helyett emisszióról beszélhetünk. A kötési állandókat, azok szórását és az emittáló komponensek „egyedi spektrumát” a program a mért adatsorokból és az alábbi anyagmérlegek alkalmas matematikai módszerrel való megoldásával számítja:

$$
\begin{aligned}
& \mathrm{p}(\text { ligandum })+\mathrm{q}(\mathrm{HSA}) \rightleftharpoons(\text { ligandum })_{\mathrm{p}}(\mathrm{HSA})_{\mathrm{q}}, \\
& \beta^{*}{ }_{p q}=\left[(\text { ligandum })_{p}(\text { HSA })_{\mathrm{q}}\right] /[\text { ligandum }]^{\mathrm{p}}[\mathrm{HSA}]^{\mathrm{q}}, \\
& \mathrm{c}_{\text {ligandum }}=[\text { ligandum }]+\sum_{\mathrm{i}=1}^{\mathrm{n}} \mathrm{p}_{\mathrm{i}} \beta^{*}{ }_{\mathrm{pq}}[\text { ligandum }]^{\mathrm{p}_{\mathrm{i}}}[\mathrm{HSA}]^{\mathrm{q}_{\mathrm{i}}} \\
& \mathrm{c}_{\mathrm{HSA}}=[\mathrm{HSA}]+\sum_{\mathrm{i}=1}^{\mathrm{n}} \mathrm{q}_{\mathrm{i}} \beta^{*}{ }_{\mathrm{pq}}[\text { ligandum }]^{\mathrm{p}_{\mathrm{i}}}[\mathrm{HSA}]^{\mathrm{q}_{\mathrm{i}}}
\end{aligned}
$$


ahol $\beta_{\mathrm{pq}}^{*}=$ látszólagos kötési állandó HSA-ligandum adduktumra, $\mathrm{c}_{\mathrm{x}}=\mathrm{x}$ komponens analitikai (teljes) koncentrációj, $[\mathrm{x}]=\mathrm{x}$ komponens egyensúlyi koncentrációja, $\mathrm{q}, \mathrm{p}=1$ (nagy hígítások miatt csak 1:1 arányú komplexek létrejöttével számoltunk).

Spektrofluorimetriában a mért intenzitás a következő összefüggésben áll a komponensek/asszociátumok koncentrációjával:

$$
\mathrm{I}_{\mathrm{i}}=\phi_{\text {ligandum }} \times[\text { ligandum }]+\dot{\phi}_{H S A} \times[\mathrm{HSA}]+\dot{\phi}_{\text {HSA-ligandum }} \times[\mathrm{HSA}-\text { komplex }]
$$

ahol $\mathrm{I}_{\mathrm{i}}=$ fluoreszcenciás emisszió intenzitása az "i”"-edik hullámhosszon, $\phi_{x}=$ "moláris intenzitás". ${ }^{176}$

\subsection{Ultraszürés}

Az ultraszürés ${ }^{177}$ segítségével a fehérjéhez kötött és a nem-kötött frakciót választjuk el az egyensúly beállását követően. Az összeállított mintát (esetünkben HSA + ligandum/fémkomplex ill. HSA + kötőhely marker + ligandum/fémkomplex) megfelelő idejü és körülményü inkubálás után egy speciális szürőre visszük fel, mely csak az adott méretnél kisebb molekulákat engedi át. A megfelelő ideig tartó és alkalmas fordulatszámon végzett centrifugálást követően két frakciót nyerünk: a szürőn fennmaradt rész az ún. HMM (az angol „high molecular mass” nagy molekulatömegü rövidítéséből), míg a szürőn átjutott rész az LMM („low molecular mass” azaz kis molekulatömegü) frakció. A szürőn marad tehát a fehérje és a hozzá kötött ligandum/fémkomplex/kötőhely marker, míg a nem-kötődő anyagok átjutnak. Mindkét frakció összetétele vizsgálható alkalmas analitikai módszerrel, pl. UV-látható spektrofotometria, ICP-AES, AAS stb.

A HSA-adduktum közvetlen kölcsönhatására vonatkozó ultraszüréses mérések esetén a nem-kötött fémkomplex egyensúlyi koncentrációját az elválasztást követően spektrofotometriás mérésekkel határoztuk meg, megfelelő referenciaspektrumok és kalibrálás segítségével. A látszólagos stabilitási állandókat PSEQUAD ${ }^{170}$ programmal határoztuk meg, a különböző fehérje-adduktum aránynál mért összes és szabad ligandum koncentráció segítségével. A méréseket $0,1 \mathrm{M}, 7,4-\mathrm{es}$ pH-jú HEPES pufferben, 0,50 $\mathrm{cm}^{3}$ térfogatban $25{ }^{\circ} \mathrm{C}$-on végeztük. A mintákban a HSA koncentrációja állandó, $\sim 200 \mu \mathrm{M}$, volt, a ligandumok koncentrációját $50 \mu \mathrm{M}$ és $1 \mathrm{mM}$ között változtattuk. A minták összeállítását követően 2 órás inkubáció után centrifugálást végeztünk. Erre a célra Sanyo centrifugát használtunk, 10 percig, $10000 \mathrm{rpm}$ fordulaton. A szürő Microcon YM-10, Amicon, Millipore membránszürő volt. Előzetes kalibrációt követően az így szétválasztott mintáknak a fehérjementes LMM frakcióját vizsgáltuk Hewlett-Packard 8452A típusú 
diódasoros spektrofotométerrel. A számolt kötési állandókat PSEQUAD programmal határoztuk meg ismerve az össz, illetve a szabad ligandum koncentrációt a különböző fehérje-ligandum arányok mellett.

$$
\begin{aligned}
& \mathrm{p}(\text { ligandum })+\mathrm{q}(\mathrm{HSA}) \rightleftharpoons(\text { ligandum })_{\mathrm{p}}(\mathrm{HSA})_{\mathrm{q}}, \\
& \beta_{\mathrm{pq}}^{*}=\left[(\text { ligandum })_{\mathrm{p}}(\mathrm{HSA})_{\mathrm{q}}\right] /[\text { ligandum }]^{\mathrm{p}}[\mathrm{HSA}]^{\mathrm{q}}, \\
& \mathrm{c}_{\mathrm{HSA}}=[\mathrm{HSA}]+\sum_{\mathrm{i}=1}^{\mathrm{n}} \mathrm{q}_{\mathrm{i}} \beta^{*}{ }_{\mathrm{pq}}[\text { ligandum }]_{\mathrm{i}}^{\mathrm{p}}[\mathrm{HSA}]_{\mathrm{i}}^{\mathrm{q}}, \\
& \mathrm{c}_{\text {ligandum }}=[\text { ligandum }]+\sum_{\mathrm{i}=1}^{\mathrm{n}} \mathrm{p}_{\mathrm{i}} \beta^{*}{ }_{\mathrm{pq}}[\text { ligandum }]_{\mathrm{i}}^{\mathrm{p}}[\mathrm{HSA}]_{\mathrm{i}}^{\mathrm{q}} \text {, }
\end{aligned}
$$

ahol $\beta_{\mathrm{pq}}^{*}=$ látszólagos kötési állandó HSA-ligandum adduktumra, $\mathrm{c}_{\mathrm{x}}=\mathrm{x}$ komponens analitikai (teljes) koncentrációja és $[\mathrm{x}]=\mathrm{x}$ komponens egyensúlyi koncentrációja. 


\section{Eredmények és értékelésük}

\subsection{A [Ru(II)- $\eta^{6}-p$-cimol] és a ligandumok bemutatása és sav-bázis sajátságaik}

\subsubsection{A [Ru(II)- $\eta^{6}-p$-cimol] hidrolízise}

Mint ahogy az az irodalmi részben részletesen kifejtésre került, a $\left[\mathrm{Ru}(\mathrm{II})-\eta^{6}-p\right.$-cimol] hidrolízise kloridos- és kloridmentes közegben az irodalomból már jól ismert. ${ }^{136,166}$ Kísérleti munkánk során azonban szükséges volt a $\left[\mathrm{Ru}(\mathrm{II})-\eta^{6}-p\right.$-cimol] hidrolízisének vizsgálata a mi laboratóriumi körülményeink között is. Célunk egyrészt az eredmények reprodukálása volt, másrészt a $\left[\mathrm{Ru}(\mathrm{II})-\eta^{6}\right.$-p-cimol]-ligandum rendszerek UV-látható és ${ }^{1} \mathrm{H}$ NMR spektrumainak kiértékeléséhez igen hasznosnak bizonyult a fémion saját $\mathrm{pH}$-függő spektrumainak ismerete. Ezért pH-potenciometria, UV-látható spektrofotometria és ${ }^{1} \mathrm{H}$ NMR módszerekkel vizsgáltuk a hidrolitikus folyamatokat klorid- és kloridmentes közegben. Az általunk meghatározott állandók (2. táblázat) viszonylag jó egyezést mutatnak a korábbi irodalmi adatokkal. ${ }^{136,166}$

Az irodalmi bevezetésnél tárgyalt (1. táblázat és a 11. ábra) bonyolult kép ellenére, véleményünk szerint $\left[\mathrm{Ru}(\mathrm{II})-\eta^{6}-p\right.$-cimol]-t tartalmazó rendszereink jellemzésére, az általánosan használt $0,2 \mathrm{M}$ klorid-koncentráció mellett jó közelítéssel használható a debreceni csoport által korábban, 2009-ben meghatározott modell is. ${ }^{136}$ Így rendszereink leírására a régebbi modellt használtuk és $0,2 \mathrm{M} \mathrm{KCl}$ vizes oldatában [Ru(II)- $\eta^{6}-p$ $\left.\operatorname{cimol}\left(\mathrm{H}_{2} \mathrm{O}\right)_{3}\right]=\mathrm{M} ; \mathrm{M}_{2} \mathrm{H}_{2} ; \mathrm{M}_{2} \mathrm{H}_{3}$ részecskéket feltételezve értékeltük méréseinket és számítottuk ki a 2. táblázatban feltüntetett látszólatos stabilitási állandókat. Az egyes módszerekkel meghatározott stabilitási szorzatok viszonylag jó egyezést mutatnak az irodalomban korábban meghatározott állandókkal. ${ }^{136}$

2. táblázat: Fém-hidroxidokomplexek különböző módszerekkel meghatározott stabilitási szorzatai ${ }^{\mathrm{a}}\left(\mathrm{t}=25^{\circ} \mathrm{C}, \mathrm{I}=0,20 \mathrm{M}^{\mathrm{b}, \mathrm{c}}\right)$

\begin{tabular}{lcc} 
& $\lg \boldsymbol{\beta}\left[\mathbf{M}_{\mathbf{2}} \mathbf{H}_{-2}\right]$ & $\lg \boldsymbol{\beta}\left[\mathbf{M}_{\mathbf{2}} \mathbf{H}_{-3}\right]$ \\
\hline kloridmentes közegben $^{\mathbf{b , d}}$ : & & $-9,36(2)$ \\
pH-metria & - & $-9,38(1)$ \\
UV-látható sp. $^{\text {kloridion-tartalmú közegben }}{ }^{\mathbf{c , d}}:$ & $-6,97(2)$ & $-11,97(1)$ \\
pH-metria & $-7,02(5)$ & $-11,68(6)$ \\
UV-látható sp. &
\end{tabular}

\footnotetext{
${ }^{a}$ A zárójelben az állandókra számolt utolsó jegy bizonytalansága van feltüntetve.

${ }^{\mathrm{b}} \mathrm{I}=0,2 \mathrm{M} \mathrm{KNO}_{3} ;{ }^{\mathrm{c}} \mathrm{I}=0,2 \mathrm{M} \mathrm{KCl}$

d Irodalmi adatok hasonló körülmények között (kloridmentes közegben: $\lg \beta\left[\mathrm{M}_{2} \mathrm{H}_{-3}\right]=-9,16^{166} ; \mathrm{I}=0,2 \mathrm{KCl}$ : $\lg \beta\left[\mathrm{M}_{2} \mathrm{H}_{2}\right]=-7,12, \lg \beta\left[\mathrm{M}_{2} \mathrm{H}_{3}\right]=-11,88^{136}$
} 
Kloridmentes vizes közegben a speciáció egyszerüen leírható. A $\left[\mathrm{Ru}(\mathrm{II})-\eta^{6}-p-\right.$ $\left.\operatorname{cimol}\left(\mathrm{H}_{2} \mathrm{O}\right)_{3}\right]^{2+}$ illetve a pH 4 felett dominánssá váló kétmagvú [(Ru(II)- $\eta^{6}-p-$ cimol $\left.)_{2}(\mathrm{OH})_{3}\right]^{+}\left(\left[\mathrm{M}_{2} \mathrm{H}_{3}\right]\right)$ komplexek jelenlétének feltételezésével (14. ábra).

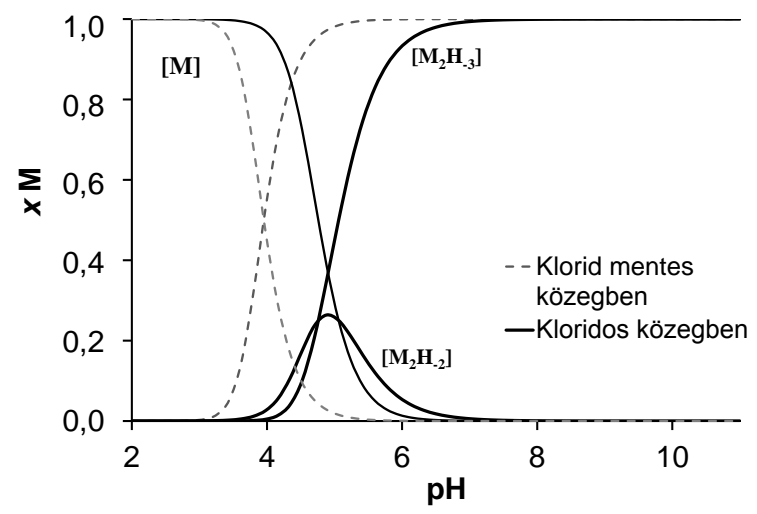

14. ábra: $\left[\mathrm{Ru}(\mathrm{II})-\eta^{6}-p\right.$-cimol] koncentrációeloszlási diagramja vízben (szaggatott vonal, $\mathrm{I}=0,2 \mathrm{M} \mathrm{KNO}_{3}$ ) és az egyszerúsített modellt alapul véve $0,2 \mathrm{M} \mathrm{KCl}$ tartalmú vizes közegben (folytonos vonal)

$$
\left(\mathrm{c}_{\mathrm{M}}=2,0 \times 10^{-3} \mathrm{M}, \mathrm{t}=25^{\circ} \mathrm{C}\right)
$$

A részecskék jele az ${ }^{1} \mathrm{H}$ NMR pH-függő spektrumokon is jól azonosítható (15. ábra). Az egyes részecskékhez tartozó NMR jelek integráljaiból becsült mólarány jól egyezik a pHpotenciometriás állandók segítségével számolt eloszlással (16. ábra). A pH-metriás és UVlátható spektrofotometriás mérésekből meghatározott $\left[\left(\mathrm{Ru}(\mathrm{II})-\eta^{6}-p \text {-cimol }\right)_{2}(\mathrm{OH})_{3}\right]^{+}$ komplex stabilitási szorzata jó egyezést mutatnak egymással és az irodalmi adatokkal.

a.

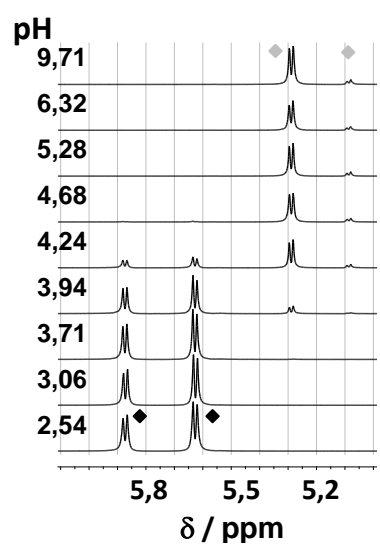

b.

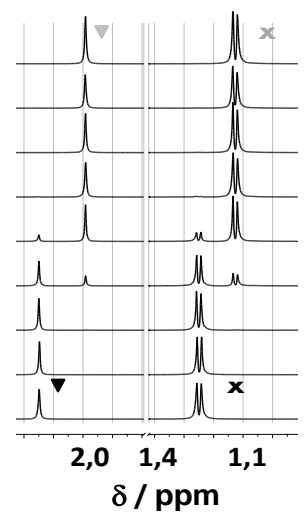

15. ábra: $\left[\mathrm{Ru}(\mathrm{II})-\eta^{6}-p\right.$-cimol] $\mathrm{pH}$-függö ${ }^{1} \mathrm{H}$ NMR spektrumainak részletei a spektrum aromás (a.) és alifás (b.) régiójában kloridmentes közegben. $\left[\mathrm{Ru}(\mathrm{II})-\eta^{6}-p \text {-cimol }\left(\mathrm{H}_{2} \mathrm{O}\right)_{3}\right]^{2+}$ jelei: $\operatorname{Ar}(\mathrm{CH}) ; \boldsymbol{\nabla ~} \mathrm{CH}_{3} ; \mathbf{x}$ iProp $\left(\mathrm{CH}_{3}\right)$. $\left[\left(\mathrm{Ru}(\mathrm{II})-\eta^{6}-p \text {-cimol }\right)_{2}(\mathrm{OH})_{3}\right]^{+}$jelei: $\wedge \mathrm{Ar}(\mathrm{CH}) ; \nabla \mathrm{CH}_{3} ; \mathrm{x}$ iProp $\left(\mathrm{CH}_{3}\right)$. $\left(\mathrm{c}_{\mathrm{M}}=1 \times 10^{-3} \mathrm{M}, \mathrm{I}=0,2 \mathrm{M} \mathrm{KNO}_{3}, \mathrm{t}=25^{\circ} \mathrm{C}, 10 \% \mathrm{D}_{2} \mathrm{O}\right)$ 


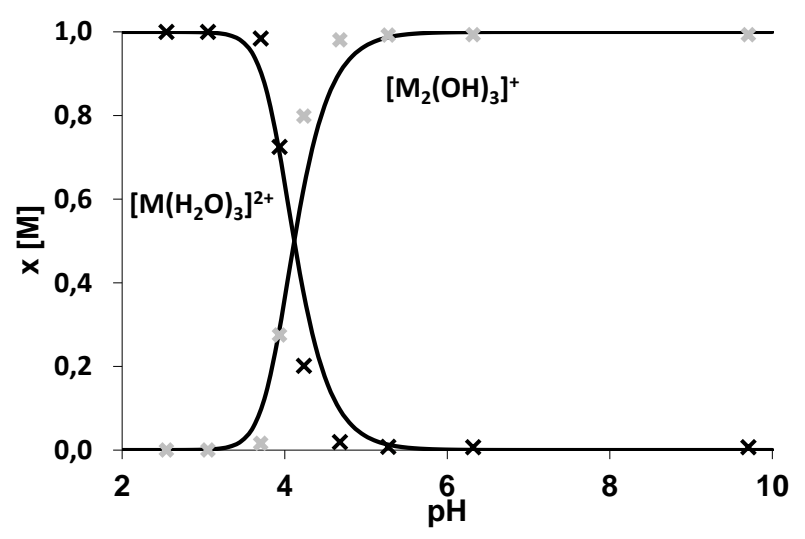

16. ábra: $\mathrm{A}\left[\mathrm{Ru}(\mathrm{II})-\eta^{6}-p\right.$-cimol] hidrolízisének koncentrációeloszlás diagramja a pH-potenciometriás titrálások alapján meghatározott stabilitási szorzat (folytonos vonalak), és az ${ }^{1} \mathrm{H}$ NMR spektrumok iProp $\left(\mathrm{CH}_{3}\right)$ jeleinek csúcs alatti területeiből számolt móltörtek alapján $(\times)$ kloridmentes közegben.

$$
\left(\mathrm{c}_{\mathrm{M}}=1 \times 10^{-3} \mathrm{M}, \mathrm{I}=0,2 \mathrm{M} \mathrm{KNO}_{3}, \mathrm{t}=25^{\circ} \mathrm{C}, 10 \% \mathrm{D}_{2} \mathrm{O}\right)
$$

Kloridos közegben habár a speciáció jóval bonyolultabb a kloridion koordinálódása miatt (10. és 11. ábra), ${ }^{166}$ a bonyolult rendszer ellenére a hidrolízis viszonylag jól modellezhető csupán három $\left(\mathrm{M}, \mathrm{M}_{2} \mathrm{H}_{2}, \mathrm{M}_{2} \mathrm{H}_{-3}\right)$ komplex jelenlétének feltételezésével (14. ábra). Ez modell nem tesz különbséget az azonos deprotonáltságú, azonban eltérő számú klorid illetve vízmolekulát tartalmazó komplexek között, másrészt elhanyagolja a kis stabilitású, emiatt jelentéktelen mennyiségben képződő $\left[\mathrm{M}_{2} \mathrm{H}_{-1}\right]$ komplex jelenlétét. A pH-potenciometriás titrálásokból illetve a pH-függő UV-látható spektrofotometriás spektrumok változásai alapján számolt állandók szintén hasonlóak a debreceni kutatócsoport által korábban meghatározott stabilitási állandókkal. ${ }^{136}$

\subsection{2. $(\mathrm{O}, \mathrm{O}),(\mathrm{O}, \mathrm{N})$ és $(\mathrm{O}, \mathrm{S})$ ligandumok}

A ligandumok sav-bázis egyensúlyait pH-potenciometriás, UV-látható spektrofotometriás és ${ }^{1} \mathrm{H}$ NMR spektroszkópiai módszerekkel vizsgáltuk, a kapott proton disszociációs állandókat az 3. táblázatban mutatjuk be. Az irodalomból ezek már ismert adatok. ${ }^{178,179}$ Célunk egyrészt az volt, hogy a mi laboratóriumi körülményeink között ezeket az eredményeket reprodukáljuk, másrészt a ligandumok részletes vizsgálata megkönnyíti [Ru(II)- $\eta^{6}-p$-cimol]-al való komplexképződési folyamatok értelmezését. A ligandumok szerkezeti képletét, és pH-potenciometriás módszerrel meghatározott protondisszociációs állandóit a 3. táblázat mutatja. Az UV-látható spektrofotometriás és ${ }^{1}$ H NMR mérések alapján meghatározott pK-érték adatokat és spektrális sajátságait a melléklet tartalmazza (M1-a,b). A különböző módszerrel meghatározott állandók jó egyezést mutatnak egymással és az irodalmi adatokkal. 
3. táblázat: $A$ vizsgált $(\mathrm{O}, \mathrm{X})$ ligandumok $(\mathrm{X}=\mathrm{O}, \mathrm{N}$ vagy $\mathrm{S})$ szerkezeti képlete, és pH-potenciometriás módszerrel meghatározott proton disszociációs állandói $\left(\mathrm{I}=0,2 \mathrm{M} \mathrm{KCl}, \mathrm{t}=25^{\circ} \mathrm{C}\right)^{\mathrm{a}}$

\begin{tabular}{|c|c|c|c|c|c|c|}
\hline & allomaltol & etil-maltol & pik & 6-Mepik & dipik & tioallomaltol \\
\hline & $\begin{array}{l}\text { 5-hidroxi-2- } \\
\text { metilpiran-4- } \\
\text { on }\end{array}$ & $\begin{array}{c}\text { 2-etil-3- } \\
\text { hidroxipiran-4- } \\
\text { on }\end{array}$ & $\begin{array}{l}\text { piridin-2- } \\
\text { karbonsav }\end{array}$ & $\begin{array}{l}\text { 6-metilpiridin-2- } \\
\text { karbonsav }\end{array}$ & $\begin{array}{l}\text { piridin-2,6- } \\
\text { dikarbonsav }\end{array}$ & $\begin{array}{l}\text { 5-hidroxi-2- } \\
\text { metilpiran-4- } \\
\text { tion }\end{array}$ \\
\hline$p K\left(H_{2} L\right)$ & - & - & - & - & $2,01(3)$ & - \\
\hline pK(HL) & $7,98(1)$ & $8,54(1)$ & $5,17(1)$ & $5,82(1)$ & $4,59(1)$ & $7,61(1)$ \\
\hline
\end{tabular}

A ligandumok pK-értékének különbsége jól magyarázható a molekulákban lévő elektronküldő és elektronszívó szubsztituensek hatásaival. A $(\mathrm{N}, \mathrm{O})$ donoratomos ligandumok esetén a 6-Mepik elektronküldő metilcsoportja a $\mathrm{NH}^{+}$-hoz rendelhető pK-értéket növeli a pikolinsavéhoz képest, míg a dipik esetében az elektronszívó hatással rendelkező karboxilcsoportnak ellentétes hatása van. Az etil-maltol pK-értéke magasabb, mint az allomaltolé, vagy magáé a maltolé $\left(\mathrm{pK}_{\text {maltol }}=8,45\right),{ }^{179,181}$ ami az etilcsoport erősebb elektronküldő hatásának tudható be. Az tioallomaltolnak 0,37 lg egységgel kisebb a pKértéke az allomaltolhoz képest, ami a kénatom oxigénhez képest kisebb elektronegativitásával magyarázható.

\subsubsection{Hidroxi-piridinkarbonsav ligandumok}

A szervezet fémháztartás befolyásolását szolgáló kelátor molekulákkal kapcsolatos kutatásaink fó típusai szubsztituált hidroxi-piridinkarbonsavak voltak. A padovai kutatócsoport által fejlesztett és tanulmányozott ligandumok a 3-hidroxi-4piridinkarbonsav (DT0) és 4-hidroxi-3-piridinkarbonsav (DQ0) molekulák metilszubsztituált származékai. Kereskedelemben nem kaphatók, előállításuk a Padovai Egyetemen történt. ${ }^{182,183,184,185,186,187,188}$ A 17. ábra az alapligandumokat, és az általunk is részletesen vizsgált ligandumok szerkezeti képletét mutatja be teljes protonáltsági állapotban (további szerkezeti képletek a mellékletben találhatók - M2). 


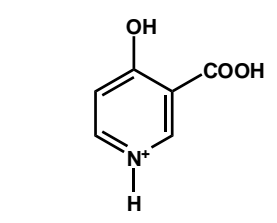

4-hidroxi-3pididinkarbonsav (DQ0)

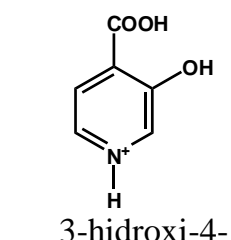
pididinkarbonsav

(DT0)<smiles>C[n+]1ccc(O)c(C(=O)O)c1</smiles>

4-hidroxi-1-metil-3pididinkarbonsav (DQ1)<smiles>C[n+]1ccc(C(=O)O)c(O)c1</smiles>

3-hidroxi-1-metil-4pididinkarbonsav (DT1)<smiles>Cc1c[nH+]cc(C(=O)O)c1O</smiles>

4-hidroxi-5-metil3-

pididinkarbonsav (DQ5)<smiles>Cc1cc(O)c(C(=O)O)c[nH+]1</smiles>
3 pididinkarbonsav (DQ6)<smiles>Cc1c[n+](C)cc(C(=O)O)c1O</smiles>

1,5-Dimetil-4hidroxi-3pididinkarbonsav (DQ715)<smiles>Cc1cc(O)c(C(=O)O)c[n+]1C</smiles>

1,6-Dimetil-4hidroxi-3pididinkarbonsav (DQ716)<smiles>Cc1cc(C(=O)O)c(O)c(C)[nH+]1</smiles>

2,6-dimetil-3hidroxi-4pididinkarbonsav (DT726)

17. ábra: Hidroxi-piridinkarbonsav ligandumok szerkezeti képlete

A piridingyürün egymáshoz képest orto-helyzetben lévő karboxil- és fenolos hidroxilcsoport deprotonált formában a fémionokkal hattagú kelátgyürü kialakítására képes. A gyürűben lévő piridin nitrogén a szalicilsavhoz képest jelentős komplex stabilitás növekedést eredményez. Hasonló hatás figyelhető meg a hidroxipiridinon származékokban is (pl. deferipron) melyek fémkomplexei nagyságrendekkel stabilabbak a pirokatechin származékok komplexeihez képest. ${ }^{194}$ A karboxil- és hidroxilcsoportok bázicitása tovább növelhető, metil-szubsztituensek jelenlétével, melyre az 2., 5. és 6. pozícióban van lehetőség, így növekedhet a ligandumok hard fémionhoz való affinitása. Különleges jelentősége lehet a metilcsoport jelenlétének 1. pozícióban, azaz a piridin nitrogénen, melynek hatására az aromás gyürüben lévő nitrogénen pozitív töltést eredményez, amely igen erős elektronszívó hatású a koordinálódni képes funkciós csoportokat tekintve.

A piridin nitrogénen protonált ligandumok három deprotonálódási lépésen, míg az Nmetil származékok két deprotonálódási lépésen mehetnek keresztül (18. ábra). N-metil csoport hiányában a molekulának három, különböző protonálható funkciós csoportja van, a $-\mathrm{COOH}$ karboxilcsoport, a $-\mathrm{NH}^{+}$piridinium, és az $-\mathrm{OH}$ fenolos hidroxilcsoport. Egyszerü esetben azt gondolnánk ezek savassága a felsorolt irányba csökken, és a meghatározott pKértékeket $\left(\mathrm{pK}_{1}<1, \mathrm{pK}_{2} \sim 5-7, \mathrm{pK}_{3} \sim 10,3-12\right)$ egyértelmüen hozzá tudjuk rendelni az adott funkciós csoporthoz. Ez a hozzárendelés azonban, különösen a DQ származékok esetében nem teljes mértékben állja meg a helyét. A 4-hidroxi-3-piridin karbonsav származékok esetében enol-oxo tautoméria léphet fel, mely során a gyürü elvesztheti aromás jellegét, és piridinon forma kialakulására van lehetőség. Hasonló tautomér átrendeződés figyelhető meg 2- és 4-hidroxipiridin származékok esetében is. ${ }^{189,190}$ 
A vizsgált ligandumok pK-értékeit UV-látható és $\mathrm{pH}$-potenciometriás mérésekkel határoztuk meg (4. táblázat).

4. táblázat: A vizsgált hidroxi-piridinkarbonsavak pH-potenciometriás és UV-látható spektrofotometriás módszerrel meghatározott proton disszociációs állandói $\left(\mathrm{I}=0,2 \mathrm{M} \mathrm{KCl}, \mathrm{t}=25^{\circ} \mathrm{C}\right)^{\mathrm{a}}$

\begin{tabular}{|c|c|c|c|c|c|c|c|}
\hline & \multirow{2}{*}{$\frac{\text { DQ1 }^{\mathbf{b}}}{\mathrm{pH}^{\mathrm{p}} \text {-pot }}$} & \multicolumn{2}{|c|}{$\mathrm{DQ5}^{\mathrm{C}}$} & \multicolumn{2}{|c|}{ DQ715 $^{\mathrm{b}}$} & \multirow{2}{*}{$\frac{\text { DQ716 }^{\mathbf{b}}}{\text { pH-pot }}$} & \multirow{2}{*}{$\frac{\text { DT726 }}{\text { pH-pot }}$} \\
\hline & & pH-pot & UV-látható & pH-pot & UV-látható & & \\
\hline $\begin{array}{c}\mathbf{p K} \\
\left(\mathbf{H}_{3} \mathbf{L}\right)\end{array}$ & - & - & $0,23(6)^{b}$ & - & $0,40(1)^{\mathrm{b}}$ & $<1$ & $<1$ \\
\hline $\begin{array}{c}\mathbf{p K} \\
\left(\mathbf{H}_{2} \mathbf{L}\right)\end{array}$ & $<1$ & 6,60 & 6,61 & $6,64(1)$ & $6,63(1)$ & $6,37(1)$ & $6,53(3)$ \\
\hline $\begin{array}{c}\mathbf{p K} \\
(\mathbf{H L})\end{array}$ & $6,11(2)$ & & $<11$ & - & - & & $11,6(1)$ \\
\hline
\end{tabular}

${ }^{a} \mathrm{~A}$ zárójelben az állandókra számolt utolsó jegy bizonytalansága van feltüntetve. ${ }^{b} \mathrm{~L}=\left(\mathrm{L}^{2-}\right) ;{ }^{c} \mathrm{~L}=\left(\mathrm{L}^{-}\right)$.

A DQ ligandumok sav-bázis tulajdonságainak pontos megértése érdekében részletes ${ }^{1} \mathrm{H}$ NMR vizsgálatokat végeztünk a DQ5 és DQ715 ligandumokkal.

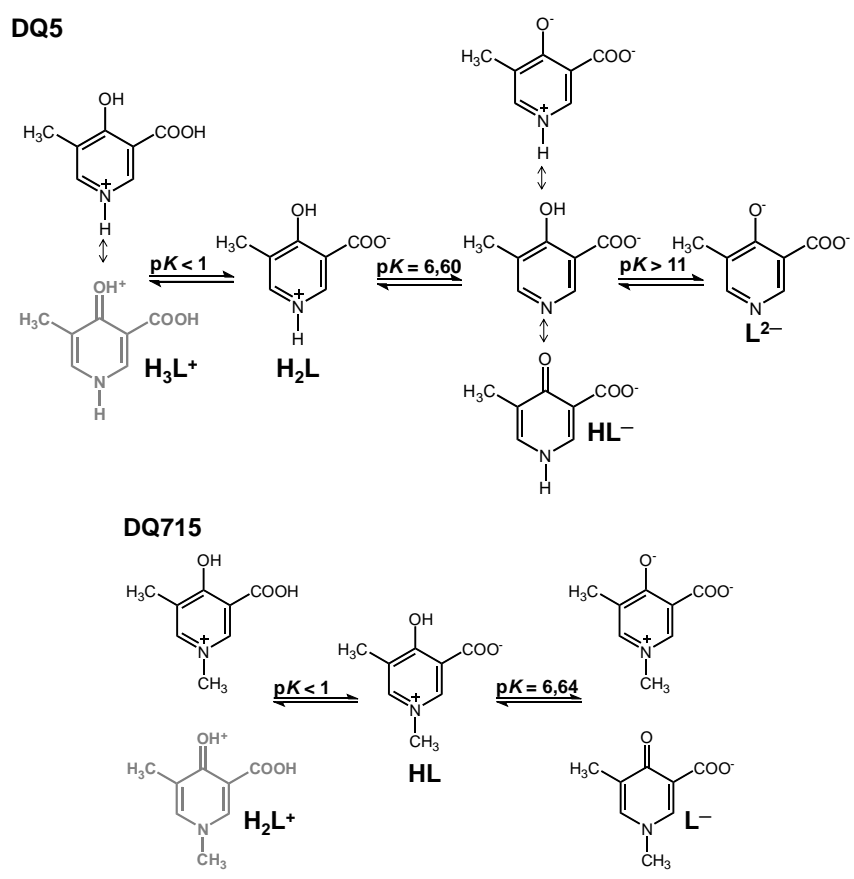

18. ábra: DQ5 és DQ715 ligandumok lehetséges proton disszociációs folyamatai

$\mathrm{Az}$ első proton disszociációs állandó $\left(\mathrm{pK}_{1}<2\right)$ mindkét ligandum esetében a karboxilcsoportokhoz rendelhető. A benzoesav karboxilcsoportjához képest a kisebb savi disszociációs állandó azzal magyarázható, hogy intramolekuláris H-kötés tud kialakulni a deprotonált karboxilát és az orto helyzetben lévő fenolos hidroxilcsoport között. Habár a ketol-enol tautoméria miatt igen savas körülmények között, a molekula teljes deprotonáltsági állapotában elképzelhető, fenolos hidroxilcsoport protonált oxocsoporttá alakul át $\left(-\mathrm{C}=\mathrm{OH}^{+}\right)$és a $\mathrm{pK}_{1}$ értéket ehhez rendeljük hozzá. A DQ származékok esetében azonban a meghatározott első disszociációs állandó jól egyezik a DT ligandumoknál meghatározottal, ahol enol-oxo tautomériára nincs lehetőség. Az aromás forma mellett szól 
az a tény is, hogy ebben az esetben, a karboxilcsoporthoz kellene rendelnünk a $\mathrm{pK}=6,6$-os értéket, amely azonban túl magas ehhez. Azokon a pH értékeken, melyeken az egyszeresen deprotonált forma dominál az ${ }^{1} \mathrm{H}$ NMR spektrumokon éles jelek figyelhetők meg, ami azt sugallja, hogy egyféle szerkezet domináns az oldatban, mely valószínűleg az aromás forma.

Az N-metil szubsztituált származékban a gyürün lévő fenolos hidroxilcsoport savassága a fenolhoz és a szalicilsavhoz képest drasztikusan csökken, ami kinoidális mezomer szerkezet kialakulására vezethető vissza. A kinoidális és aromás $\mathrm{L}^{-}$izomer formák jelenléte ${ }^{1} \mathrm{H}$ NMR méréssel is igazolható (19. ábra). A DQ715 ligandum deprotonálódási folyamatát ${ }^{1} \mathrm{H}$ NMR mérésekkel részletesen vizsgálva $\mathrm{pH}$ 2,11 és 4,50-nél felvett spektrumokon még élesek a protonált HL formához rendelhető jelek. A pH-t növelve a jelek a deprotonálódási folyamat miatt diamágnesesen eltolódnak, és kiszélesednek, aminek oka lehet a kétféle izomer egyidejű jelenléte, melyek jelei az ${ }^{1} \mathrm{H}$ NMR időskálán gyors cserefolyamatok miatt kiátlagolódnak. pH 10,35-nél a csúcsok jelei ismét élesek, lúgosabb közegben valószínűleg az aromás fenolát forma kialakulása kedvezményezett.

a.

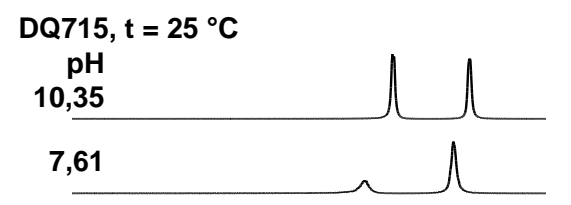

6,59

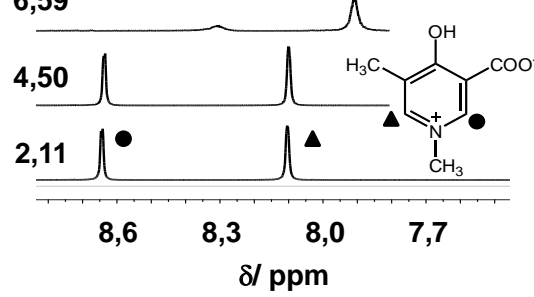

b.

$\mathrm{DQ} 5, \mathrm{t}=25^{\circ} \mathrm{C}$

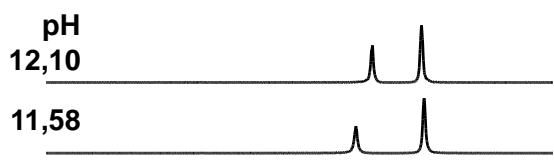

10,96

9,37

90,37

7,93

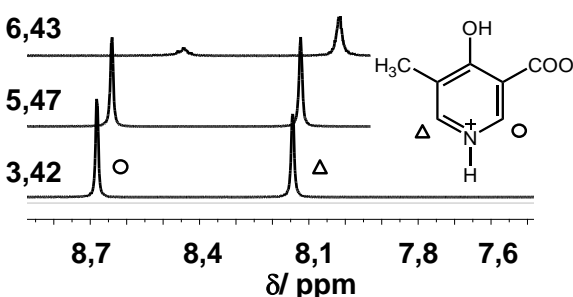

c. DQ5, $\mathrm{t}=7^{\circ} \mathrm{C}$ $\mathrm{pH}=9,37$

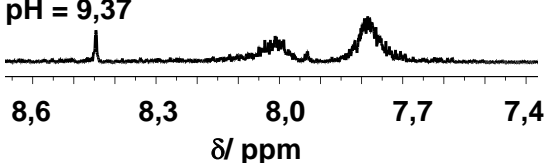

19. ábra: $\mathrm{DQ} 5^{*}$ és $\mathrm{DQ} 715^{* *} \mathrm{pH}$-függő ${ }^{1} \mathrm{H}$ NMR spektrumainak részletei a spektrum aromás régiójában $\mathrm{t}=25^{\circ} \mathrm{C}$-on $(\mathrm{a}, \mathrm{b})$ és $\mathrm{t}=7{ }^{\circ} \mathrm{C}$-on $(\mathrm{c})$.

$\left(\mathrm{c}_{\mathrm{DQ} 5}=1,1 \times 10^{-3} \mathrm{M}, \mathrm{c}_{\mathrm{DQ} 715}=2 \times 10^{-3} \mathrm{M}, \mathrm{I}=0,2 \mathrm{M} \mathrm{KCl}\right)$

$* \mathrm{pH}=6,59$ és $\mathrm{pH}=7,61$ értéknél mért spektrumok 5-szörös nagyításban láthatók. "* $\mathrm{pH}=7,93$ értéknél mért spektrumok 10-szeres, $\mathrm{pH}=9,37$ értéknél felvett spektrumok 20-szoros nagyításban láthatók. 
A piridin nitrogénen lévő metilcsoport hiányában a második és harmadik disszociációs állandó $\left(\mathrm{pK}_{2}\right.$ és $\left.\mathrm{pK}_{3}\right)$ egyértelmüen sem a hidroxil-, sem a piridin-N protonjához nem rendelhető. $\mathrm{A} \mathrm{HL}^{-}$formára három hipotetikus mezomer határszerkezet írható fel (18. ábra). A DQ5 ligandum esetében a pH-függő ${ }^{1} \mathrm{H}$ NMR spektrumok viselkedése hasonló, mint amit a DQ715 molekula vizsgálata során tapasztaltunk. Erősen savas kémhatásnál (pH 3,42) az ${ }^{1} \mathrm{H}$ NMR jelek élesek, majd a pH-t növelve a deprotonálódás miatt alacsonyabb ppm értékek felé tolódnak el, emellett a jelek kiszélesedése is megfigyelhető. pH 9,37-nél, ahol $\mathrm{HL}^{-}$forma jelenléte domináns, a jelek már alig észrevehetően emelkednek ki az alapvonalból. További lúgadagolásra a csúcsok újra megjelennek, és $\mathrm{HL}^{-}$deprotonálódása

során kialakul az $\mathrm{L}^{2-}$ forma, melynek folyamán kismértékű diamágneses jeleltolódás figyelhető meg a pH 10 felett rögzített spektrumokon a $\mathrm{HL}^{-}$forma protonvesztésének következtében. A 9,37-es pH értékü minta $8^{\circ} \mathrm{C}$-on rögzített ${ }^{1} \mathrm{H}$ NMR spektrumának aromás régiójában az egyik izomer két aromás protonjához tartozó jele élesen elkülönülve jelenik meg a spektrumon, két izomer azonban gyors cserefolyamatok miatt szélesebb átlagjelet ad, mely szintjén alátámasztja a három $\mathrm{HL}^{-}$forma egyidejü létezését az oldatban.

\subsection{Hidroxi-piridinkarbonsavak, mint fémion kelátorok a neurodegeneratív elváltozásokban}

\subsubsection{Komplexképződés három vegyértékü (Fe(III) és $\mathrm{Al}(\mathrm{III}))$ fémionokkal}

Al(III)- és Fe(III)ionok komplexképződési folyamatainak tanulmányozása hidroxipiridinkarbonsav származékokkal a Padovai Egyetemen történtek. (A DQ5 és DQ715 Fe(III)- és Al(III)ionokkal való oldategyensúlyi folyamatainak részletes tanulmányozásában magam is részt vettem.) A stabilitási állandók pH-potenciometriás és UV-látható spektrofotometriás mérések segítségével lettek meghatározva, az eredményeket ${ }^{1} \mathrm{H}$ NMR (Al(III)komplexek esetében), és ESI-MS mérések támasztják alá. ${ }^{182,183,184,185,186,187,188}$ Mindkét fémion esetben az oldat pH-jától és a piridin nitrogén szubsztituáltságától függően különböző protonáltságú mono, bisz és triszkomplexek képződnek vizes oldatban. N-metil csoport jelenlétében a fémionhoz koordinálódott vízmolekulák deprotonálódhatnak, és vegyes hidroxidokomplexek képződnek, nem szubsztituált piridin nitrogén jelenlétében a koordinálódott vízmolekula, és a $\mathrm{NH}^{+}$csoport is protont veszíthet a $\mathrm{pH}$ növekedésével. A ligandumok aszimmetriája folytán bisz és triszkomplexek képződése esetén diasztereomerek képződésére van lehetőség, melyet $\mathrm{Al}(\mathrm{III})$ komplexek esetében ${ }^{1} \mathrm{H} \mathrm{NMR}$ spektroszkópiával sikerült bizonyítani. A kialakult Fe(III)komplexek stabilitása a Fe(III) 
erősebb Lewis sav jellegének köszönhetően nagyobb, mint az Al(III)komplexeké. Azonban a vizsgált ligandumok közül csupán négy volt az, amely a Fe(III)ionokat képes volt fiziológiás pH-n is oldatban tartani, míg $\mathrm{Al}(\mathrm{III})$ komplexek esetében a hidrolízis csak pH 7,4 után kezdődött el.

5. táblázat: DQ és DT ligandumok $\mathrm{pM}$-értéke $\mathrm{pH}=5,0$ és $\mathrm{pH}=7,4$ értéken

\begin{tabular}{|c|c|c|c|c|}
\hline \multirow[t]{2}{*}{ Ligandum } & \multicolumn{2}{|l|}{$\mathrm{pFe}$} & \multicolumn{2}{|l|}{$\mathrm{pAl}$} \\
\hline & $\mathrm{pH}=5,0$ & $\mathrm{pH}=7,4$ & $\mathrm{pH}=5,0$ & $\mathrm{pH}=7,4$ \\
\hline DQ0 & 11,4 & - & 9,0 & 12,4 \\
\hline DQ1 & 12,7 & - & 8,9 & 12,3 \\
\hline DQ2 & 10,9 & - & 7,5 & 12,2 \\
\hline DQ5 & 12,2 & - & 9,1 & 13,0 \\
\hline DQ6 & 11,9 & - & 8,8 & 12,8 \\
\hline DQ715 & 13,1 & 18,5 & 9,1 & 12,9 \\
\hline DQ716 & 12,6 & 18,7 & 9,2 & 12,6 \\
\hline DQ726 & 11,1 & - & 7,4 & 12,2 \\
\hline DT0 & 11,1 & - & 7,7 & 12,2 \\
\hline DT1 & 12,6 & 18,3 & 8,5 & 12,5 \\
\hline DT2 & 12,1 & - & 7,6 & 12,2 \\
\hline DT712 & 12,9 & 19,3 & 7,8 & 12,8 \\
\hline DT726 & 12,7 & - & 8,0 & 12,3 \\
\hline
\end{tabular}

Az egyes ligandumok fémionhoz való affinitása jól összevethető egymással, ha a meghatározott stabilitási állandók alapján számolt szabad fémion koncentrációt vizsgáljuk a pH függvényében azonos körülmények között (5. táblázat).

A Fe(III)komplexek stabilitása DQ ligandumok esetén a következő stabilitási trendet követi:

$$
\text { DQ715 DQ716 > DQ1 > DQ5 > DQ6 > DQ0 DQ726 > DQ2. }
$$

A sorrendből megállapítható, hogy az 1. pozícióban lévő metilcsoportnak stabilitás növelö hatása van, amit további metil-szubsztituensek jelenléte tovább fokoz (DQ715 és DQ716 > DQ1). A 6. és különösképpen az 5. pozícióban lévő metilcsoport a -NH+ származékok esetében növeli a ligandum affinitását a vas(III)ionhoz (az előbbiekkel analóg módon DQ5 és DQ6 > DQ0). Ellentétes hatás figyelhető meg 2-metil származékok esetében. A DQ2 ligandum vas(III)komplexe a legkisebb stabilitású, amelynek magyarázata lehet, hogy a 2 . pozícióban lévő metilcsoport sztérikusan gátolja, hogy a 3. helyen lévő nagyobb méretü karboxilcsoport a piridin gyürühöz képest ko-planárisan helyezkedjen el, ami akadályozza a kelátgyürü kialakulását, így csökkenti a komplex stabilitását. DQ726 ligandum esetében a 6. helyzetben lévő metilcsoportnak, a DQ2 komplexhez képest, a korábbiakkal egyezően stabilitás növelő hatása van. 
Hasonlóan a Fe(III)komplexeknél, alumíniumkomplexek esetében is megfigyelhető, hogy a gyürü 5. és 6. pozíciójában lévő metilcsoportok növelik a komplex stabilitását, míg a 2. pozícióban lévőnek stabilitás csökkentő hatása van. Az alumíniumkomplexek stabilitására, hasonlóan a $\mathrm{Zn}$ (II) és $\mathrm{Cu}(\mathrm{II})$ komplexekhez a N-en lévő metilcsoportnak nincs hatása. A megfigyelt stabilitási trend a következő:

$$
\text { DQ715 DQ5 > DQ716 DQ6 > DQ1 DQ0 > DQ726 DQ2. }
$$

DT ligandumok esetében, hasonlóan a DQ ligandumokhoz a N-metil származékok vas(III)komplexek stabilitása szintén nagyobb, mint a szubsztituálatlan piridin-N esetében. Al(III)komplexeknél ilyen sorrendet nem lehet megállapítani, a vizsgált DT-ligandumok komplexeinek stabilitása nagyon hasonló, a metilcsoportoknak nincs szignifikáns stabilitás növelő hatása.

\subsubsection{Komplexképződés két vegyértékü (Cu(II) és $\mathrm{Zn}(\mathrm{II}))$ fémionokkal}

$\mathrm{Cu}(\mathrm{II})$ és $\mathrm{Zn}$ (II)ionok homeosztázisának zavara szintén felelőssé tehető a $\beta$-amiloid fehérjék oligomerizációs és aggregációs folyamataiban. Irodalmi adatok alapján a $\beta$ amiloid aggregátumokban kötött réz disszociációs állandója $\left(K_{\mathrm{D}}\right)$ a $1 \mathrm{pM}-100 \mathrm{nM}$-os értékek között van. ${ }^{192}$ Emiatt az a ligandum lehet kompetítora a réznek a $\beta$-amiloid fehérjékkel szemben, amely rézkomplexének disszociációs állandója 1-10 pM közötti. ${ }^{193}$ Ez az érték kellően alacsony ahhoz, hogy a ligandum képes legyen eltávolítani a rézionokat a plakkokból, azonban más biológiailag fontos molekulákból, melyek müködése szempontjából a réz jelenléte esszenciális, nem vonja el azt. A cinkionok esetében az alkalmas ligandum cinkkomplexének $K_{D}$ értéke $10 \mathrm{nM}-100 \mathrm{nM} .{ }^{192}$ Ezért a vizsgált hidroxi-piridinkarbonsav molekulák $\mathrm{Zn}$ (II) és $\mathrm{Cu}(\mathrm{II})$ ionnal való speciációjának vizsgálatakor a célunk a komplexek $\mathrm{K}_{D}$ értékének vizsgálata, melyből meg tudjuk állapítani, hogy az aktuális ligandum milyen mértékben képes beleszólni a szervezet réz és cinkháztartásába, illetve milyen erős kompetítora lehet a fémionoknak az $\beta$-amiloid fehérjékkel szemben.

$\mathrm{Cu}(\mathrm{II})$ ion komplexeinek stabilitási szorzatait pH-potenciometriás, UV-látható spektrofotometriás és ESR mérésekkel határoztuk meg (6. táblázat). 
6. táblázat: $\mathrm{DQ5}$ és $\mathrm{DQ715}$ ligandumok $\mathrm{Cu}(\mathrm{II})$ és $\mathrm{Zn}(\mathrm{II})$ komplexeinek különböző módszerekkel meghatározott stabilitási állandói $(\lg \beta)$ és számolt $\mathrm{K}_{D}$ értéke $\left(\mathrm{t}=25^{\circ} \mathrm{C}, \mathrm{I}=0,2 \mathrm{M} \mathrm{KCl}\right)^{\mathrm{a}}$

\begin{tabular}{|c|c|c|c|c|c|c|}
\hline \multicolumn{4}{|c|}{ DQ5 } & \multicolumn{3}{|c|}{ DQ715 } \\
\hline & pH-pot & UV-látható & & pH-pot & UV-látható & ESR \\
\hline $\lg \beta\left[\mathrm{Cu}(\mathrm{HL})^{+}\right]$ & $6,24(1)$ & $6,39(3)$ & $\lg \beta\left[\mathrm{CuL}^{+}\right]$ & $6,27(1)$ & $6,41(2)$ & $6,47(2)$ \\
\hline $\lg \beta\left[\mathrm{Cu}(\mathrm{HL})_{2}\right]$ & $11,33(5)$ & $11,33(9)$ & $\lg \beta\left[\mathrm{CuL}_{2}\right]$ & $10,95(2)$ & $10,97(5)$ & $11,02(2)$ \\
\hline$K_{D}\left(\mathrm{~mol} / \mathrm{dm}^{3}\right)$ & \multicolumn{2}{|c|}{$3,1 \times 10^{-7}$} & & \multicolumn{3}{|c|}{$5,1 \times 10^{-7}$} \\
\hline \multicolumn{4}{|c|}{$\mathrm{pH}-\mathrm{pot}$} & pH-pot & \multicolumn{2}{|c|}{${ }^{1} \mathrm{H}$ NMR } \\
\hline $\lg \beta\left[\mathrm{Zn}(\mathrm{HL})^{+}\right]$ & \multicolumn{2}{|c|}{$3,75(2)$} & $\lg \beta\left[\mathbf{Z n L}^{+}\right]$ & $3,77(2)$ & \multicolumn{2}{|c|}{$3,79(3)$} \\
\hline $\lg \beta\left[\mathrm{Zn}(\mathbf{H L})_{2}\right]$ & \multicolumn{2}{|c|}{$6,9(1)$} & $\lg \beta\left[\mathrm{ZnL}_{2}\right]$ & $7,06(3)$ & \multicolumn{2}{|c|}{$6,96(7)$} \\
\hline $\mathrm{K}_{D}\left(\mathrm{~mol} / \mathrm{dm}^{3}\right)^{\mathbf{c}}$ & \multicolumn{2}{|c|}{$7,5 \times 10^{-4}$} & & \multicolumn{3}{|c|}{$8,2 \times 10^{-4}$} \\
\hline
\end{tabular}

Mindkét ligandum esetében mono és biszkomplex képződését tapasztaltuk. A két rendszerben a pH-potenciometriás titrálási görbék karaktere $\mathrm{pH}$ 5-ig különböző fémionligandum arány mellett nagyon hasonló, amiből arra következtethetünk, hogy a réz(II)ionnal való komplexképződés pH 5-ig mindkét ligandum esetében hasonló módon játszódik le (20. ábra).

a. $\mathrm{Cu}(\mathrm{II})-\mathrm{DQ} 5$
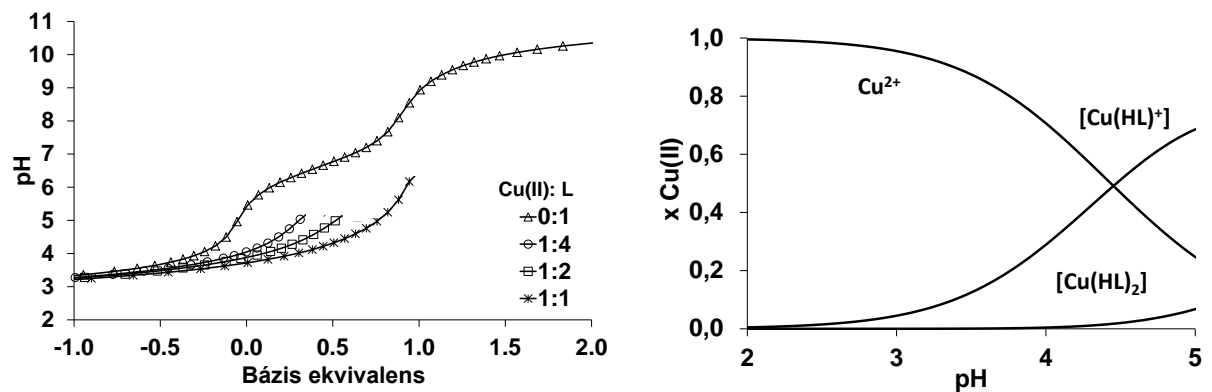

b. $\mathrm{Cu}(\mathrm{II})-\mathrm{DQ} 715$
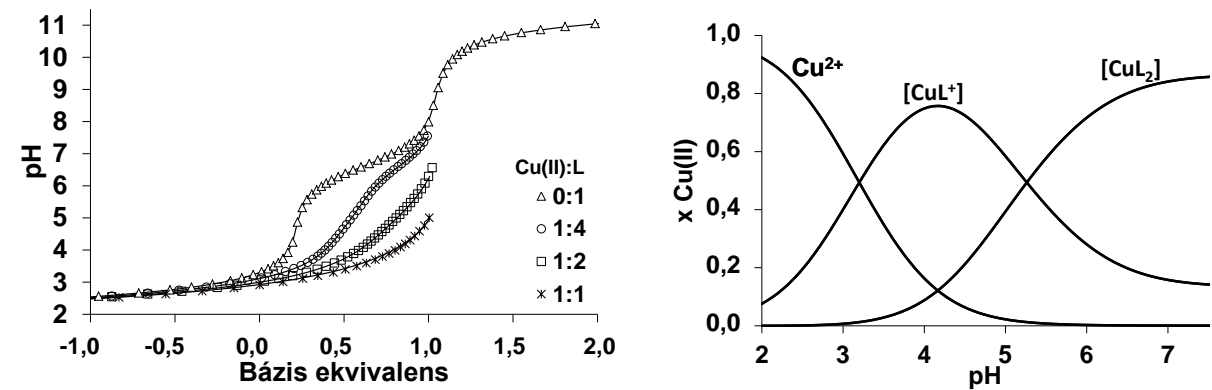

20. ábra: $\mathrm{Cu}(\mathrm{II})-\mathrm{DQ} 5$ (a) és $\mathrm{Cu}(\mathrm{II})-\mathrm{DQ} 715$ rendszerek mért és illesztett titrálási görbéi változó fémionligandum arány mellett, és koncentrációeloszlás diagramjai 1:4 fémion-ligandum aránynál $\left(\mathrm{c}_{\mathrm{DQ} 5}=1 \times 10^{-3} \mathrm{M}, \mathrm{c}_{\mathrm{DQ} 715}=2 \times 10^{-3} \mathrm{M}, \mathrm{I}=0,2 \mathrm{M} \mathrm{KCl}, \mathrm{t}=25^{\circ} \mathrm{C}\right)$

A monokomplex képződése $\mathrm{Cu}(\mathrm{II})-\mathrm{DQ} 5$ rendszerben pH 3-nál, míg DQ715 ligandum jelenlétében $\mathrm{pH}$ 2-nél kezdődik meg. DQ5 ligandum biszkomplexe $\mathrm{pH} 4$ felett jelenik meg, míg DQ715 rendszerben már pH 3-tól kimutatható. A titrálási görbéken egy deprotonálódási lépés figyelhető meg, ami a hidroxilcsoport protonvesztéséhez köthető (a 
karboxilcsoport már pH 2 alatt deprotonálódik). A komplexben kötött DQ5 ligandum piridin nitrogénje mind a mono, mind a biszkomplexben protonálva marad a vizsgált $\mathrm{pH}$ tartományban. 1:1 fémion-ligandum arány mellett a titrálások során mindkét rendszerben pH 6-7 között $\mathrm{Cu}(\mathrm{OH})_{2}$ csapadék jelent meg az oldatban, amit a titrálási görbék törése is jelez. Magasabb fémion-ligandum arány mellett DQ715 ligandum tartalmú rendszerben a $\mathrm{Cu}(\mathrm{OH})_{2}$ csapadék csak pH 9 felett jelenik meg, azaz a ligandum tovább képes a fémiont az oldatban tartani. DQ5 ligandum rendszerében azonban ligandum felesleg mellett is a titrálási görbék pH 5 felett megtörnek, az oldatban fehéres színü csapadék válik ki, amely nem köthető a fém hidrolíziséhez. Lúgos közegben ( $\mathrm{pH} 9)$ a fehéres csapadék visszaoldódik az oldatba, azonban ilyen körülmények között kék színű réz(II)-hidroxid csapadék válik ki az oldatból. Valószínüleg pH 5 felett a töltéssel nem rendelkező, kis oldhatóságú biszkomplex válik ki fehéres csapadékként az oldatból. A fehéres csapadékot leszürtük, majd $\mathrm{pH} 2$-es sósavoldatban feloldva spektrofotometriásan vizsgáltuk. Az abszorbanciás spektrum alapján a minta jelentős mennyiségü ligandumot tartalmazott. A biszkomplex stabilitási állandója alapján $\left[\mathrm{CuL}_{2}\right]$ ligandumfelesleg mellett azután válik ki az oldatból, miután koncentrációja eléri a $\sim 2,7 \times 10^{-4} \mathrm{M}$ értéket. A DQ5 ligandum maga is egy vízben kis oldhatóságú vegyület. A pH-potenciometriás titrálások kivitelezése $\sim 1 \mathrm{mM}$ ligandum koncentrációjú oldatban volt kivitelezhető. A kis oldhatóság ellenére a potenciometriás görbék értelmezése viszonylag egyértelmü képet ad a rendszer speciációjáról.

Eredményeinket mindkét ligandum esetén UV-látható spektroszkópiás mérésekkel támasztottuk alá. A spektrumokon a rézion d-d átmenetéhez tartozó abszorbciós sáv ( $\lambda \sim 680$ nm-nél) a kis koncentráció miatt nem látható a spektrumokon. A komplexképződést a ligandumok elnyelésének hullámhossz tartományán követtük nyomon $(\lambda=230$ $350 \mathrm{~nm})$, amelyek nagy moláris abszobanciája (DQ5: $\varepsilon\left(\mathrm{H}_{2} \mathrm{~A}^{+}\right)=6770(252 \mathrm{~nm}) \varepsilon(\mathrm{HA})=$ $6770(260 \mathrm{~nm})$; DQ715: $\left.\varepsilon(\mathrm{HA})=8070(256 \mathrm{~nm}) \varepsilon\left(\mathrm{HA}^{+}\right)=13000(268 \mathrm{~nm})\right)$ lehetővé tett, hogy $10^{-5}$ M-os koncentrációtartományban végezzük a méréseket. Ilyen körülmények között DQ5 ligandum kis oldhatóságú biszkomplexe is oldatban marad. Néhány reprezentatív pH-függő, a Cu(II)-DQ715 rendszerben rögzített UV-látható spektrumot, illetve az abszorbancia változását $268 \mathrm{~nm}$ hullámhossz értéknél a pH függvényében különbözö fémion-ligandum arány mellett a 21 . ábra mutat. 


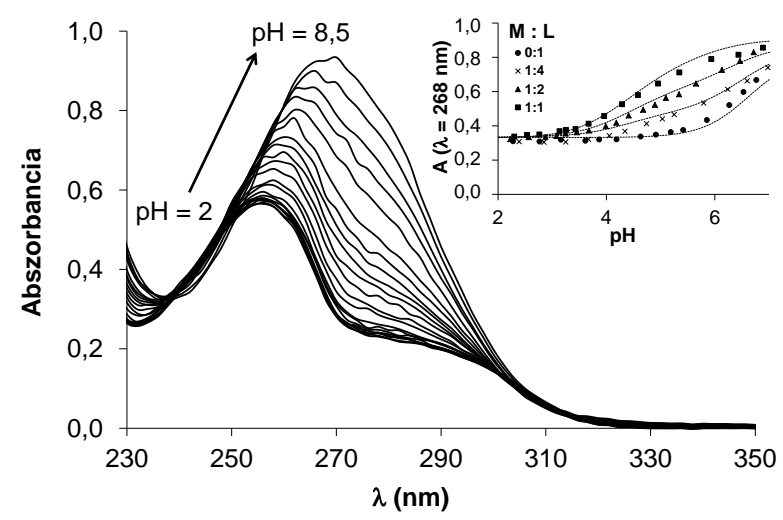

21. ábra: $\mathrm{Cu}(\mathrm{II})-\mathrm{DQ} 715$ rendszer $\mathrm{pH}$-függő, hígítással korrigált UV-látható spektrumai 1:2 fémionligandum arány mellett. A beszúrt diagram az abszorbancia változását mutatja a pH-függvényében $\lambda=268$ nm-en a számolt állandók alapján illesztett görbékkel együtt (szaggatott vonal) $\left(\mathrm{c}_{\mathrm{DQ} 715}=8 \times 10^{-5} \mathrm{M}, \mathrm{c}_{\mathrm{cu}(\mathrm{II})}=2 \times 10^{-5}-8 \times 10^{-5} \mathrm{M}, \mathrm{I}=0,2 \mathrm{M} \mathrm{KCl}, \mathrm{t}=25^{\circ} \mathrm{C}\right)$

A spektrumok karaktere, és változása nagyon hasonló mindét ligandum esetében, és a réz(II) jelenléte is csak kis mértékben befolyásolja a spektrumok alakját a ligandumok saját abszorbancia spektrumaihoz képest. A spektrumokon a $\pi \rightarrow \pi *$ átmenetet jellemző abszorbancia maximuma a pH-t növelve batokróm eltolódást szenved (DQ5: $252 \mathrm{~nm} \rightarrow 260 \mathrm{~nm}$; DQ715: $256 \mathrm{~nm} \rightarrow 268 \mathrm{~nm}$ ), amely változás a fenolos hidroxilcsoport deprotonálódásához, és fémionhoz való koordinálódásához köthető. A pH-metriás méréshez hasonlóan DQ715 jelenlétében $[\mathrm{CuL}]^{+}$és $\left[\mathrm{CuL}_{2}\right]$, míg $\mathrm{Cu}(\mathrm{II})-\mathrm{DQ} 5$ rendszerben piridin-N-en protonált mono és biszkomplex jelenléte feltételezhető, melyek meghatározott stabilitási szorzata jó egyezést mutat a potenciometriás mérések során számolt értékekkel (6. táblázat).

A tetragonálisan torzult oktaéderes geometriájú $\mathrm{Cu}$ (II)komplexek paramágnesesek, ami miatt lehetőség van ESR mérések elvégzésére, mely módszerrel a kialakuló koordinációs módok jól tanulmányozhatók.

A $\mathrm{Cu}(\mathrm{II})-\mathrm{DQ715}$ rendszerben mért izotróp és anizotróp ESR spektrumok a réz akvakomplex jele mellett, $[\mathrm{CuL}]^{+}$és $\left[\mathrm{CuL}_{2}\right]$ komplexek feltételezéseivel írhatók le $(22$. ábra). pH 2-nél a ligandum jelenlétében felvett spektrum kis mértékben eltér a réz(II)-oldat spektrumától, ami jelzi CuL komplex megjelenését már ilyen savas oldatban is. Azonban jelentős mennyiségben a $\mathrm{Cu}$ (II)ion akvakomplexe van jelen, amelynek paramétereit független mérésekből ismerjük. A pH-t tovább növelve a spektrumok hiperfinom felhasadása egyre tisztábban jelenik meg. A komplexképződéssel párhuzamosan a g-érték kismértékü csökkenése

$$
g \mathrm{Cu}(\mathrm{II})<g[\mathrm{CuL}]<g\left[\mathrm{CuL}_{2}\right]
$$

és $A$ hiperfinom csatolási állandó növekedése a ligandumtér növekedésére utal, amit a ligandum $\left(\mathrm{COO}^{-}\right.$és $\left.\mathrm{O}^{-}\right)$donorcsoportjainak fémionhoz való (gyenge) koordinációja okoz. 


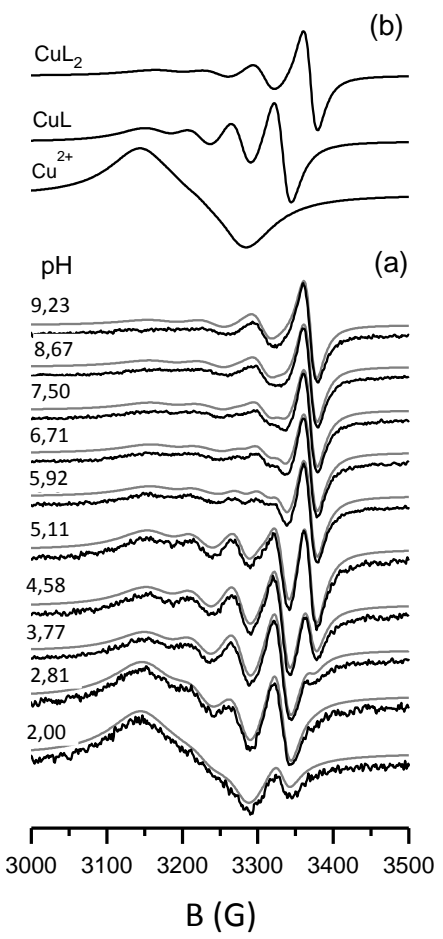

22. ábra: $\mathrm{Cu}(\mathrm{II})-\mathrm{DQ} 715$ rendszer pH-függő ESR spektrumai (fekete - mért spektrum; szürke vonal - illesztett spektrum, a láthatóság kedvéért kicsit eltolva) (a)

és a rendszer komponenseinek egyedi spektrumai (b)

$\left(\mathrm{c}_{\mathrm{DQ} 715}=2 \times 10^{-3} \mathrm{M}, \mathrm{c}_{\mathrm{Cu}(\mathrm{II})}=1 \times 10^{-3} \mathrm{M}, \mathrm{I}=0,2 \mathrm{M} \mathrm{KCl}, \mathrm{t}=25^{\circ} \mathrm{C}\right)$

A komplexek szerkezetéről még több információval szolgálnak a megfagyasztott oldatban felvett anizotróp ESR spektrumok. $[\mathrm{CuL}]^{+}$komplex esetében a $g_{x}$ és $g_{y}$ érték megegyezik, és $\left[\mathrm{CuL}_{2}\right]$ komplex esetében sem tér el a két érték egymástól jelentős mértékben. A $g_{z}$ érték azonban mindkét komplexnél jelentősen nagyobb, amiből feltételezhető, hogy a koordinálódó donoratomok az xy-síkban vannak, azaz a $\mathrm{Cu}$ (II)komplexek esetében megszokott megnyúlt oktaéderes (tetragonális bipiramisos) geometriai szerkezetről van szó. Az anizotróp spektrumok alapján megjósolható a hiperfinom csatolási állandó irányfüggő komponenseinek értékei is, melynek átlaga $\left(A_{\mathrm{o}}=\left(A_{\mathrm{x}}+A_{\mathrm{y}}+\right.\right.$ $\left.A_{z}\right)$ / 3) jó egyezést mutat az izotróp spektrumok alapján számolt értékkel, amiből arra következtetünk, hogy komplexek szerkezete a fagyasztás alatt sem változik meg (7. táblázat). 
7. táblázat: $\mathrm{Cu}(\mathrm{II})-\mathrm{DQ} 715$ rendszerben kialakult komplexek ESR-paraméterei

\begin{tabular}{|c|c|c|c|c|c|c|c|c|}
\hline & \multicolumn{2}{|c|}{$\begin{array}{l}\text { Izotróp ESR } \\
\text { paraméterek }^{\text {a }}\end{array}$} & \multicolumn{4}{|c|}{ Anzotróp ESR paraméterek } & \multicolumn{2}{|c|}{$\begin{array}{c}\text { Számolt izotróp } \\
\text { ESR paraméterek }\end{array}$} \\
\hline & $g_{0}$ & $\underset{/ G}{\left|A_{0}\right|}$ & $\begin{array}{c}g_{\perp} \\
g_{\mathrm{x}}, g_{\mathrm{y}}\end{array}$ & $\begin{array}{l}g_{\| I I} \\
g_{z}\end{array}$ & $\begin{array}{c}A \perp / G \\
A_{\mathrm{x}}, A_{\mathrm{y}} / G^{\mathrm{c}}\end{array}$ & $\begin{array}{c}A_{\|} / G \\
A_{\mathrm{z}} / G\end{array}$ & $g_{\text {o,calc }}$ & $\mid \underset{/ G}{\left|A_{0, \text { kal }}\right|^{\mathrm{b}}}$ \\
\hline $\mathrm{Cu}^{2+}$ & $2,194(1)$ & $34,6(6)$ & 2,079 & 2,412 & 8,0 & $-116,0$ & 2,190 & 37,5 \\
\hline$[\mathrm{CuL}]^{+}$ & $2,166(1)$ & $53,1(1)$ & $2,069,2,069$ & 2,347 & $12,0,-12,0$ & $-147,0$ & 2,161 & 53,2 \\
\hline$\left[\mathrm{CuL}_{2}\right]$ & $2,149(1)$ & $60,8(1)$ & $2,066,2,059$ & 2,329 & $-8,1,-15,9$ & $-150,4$ & 2,151 & 62,0 \\
\hline
\end{tabular}

${ }^{a} \mathrm{~A}$ zárójelben az állandókra számolt utolsó jegy bizonytalansága van feltüntetve.

${ }^{\mathrm{b}} A_{\mathrm{o}, \mathrm{kal}}|=|\left(A_{\mathrm{x}}+A_{\mathrm{y}}+A_{\mathrm{z}}\right) / 3 \mid$

DQ1, DQ716 és DT726 ligandum komplexképződési folyamatairól Cu(II)vel pHpotenciometriás mérésekkel nyertünk információt (8. táblázat). A DQ1 és DQ716 ligandumok 4-hidroxi-3-piridinkarbonsav család 1-metil és 1,6-dimetil származéka, melyekben a piridin-N metilált állapotban van. A DT726 3-hidroxi-4-piridinkarbonsav származék, két metilcsoporttal a gyürü 2. és 6. pozíciójában (17. ábra). Hasonlóan a DQ715 és DQ5 ligandumok $\mathrm{Cu}(\mathrm{II})$ komplexeihez, ezekben a rendszerekben is mono és biszkomplex képződését feltételezzük (23. ábra). DQ1 esetében pH 3,5 értéknél ligandum feleslegnél fehéres színü csapadék vált ki az oldatból, ami feltételezhetően a kis oldhatóságú semleges biszkomplex.
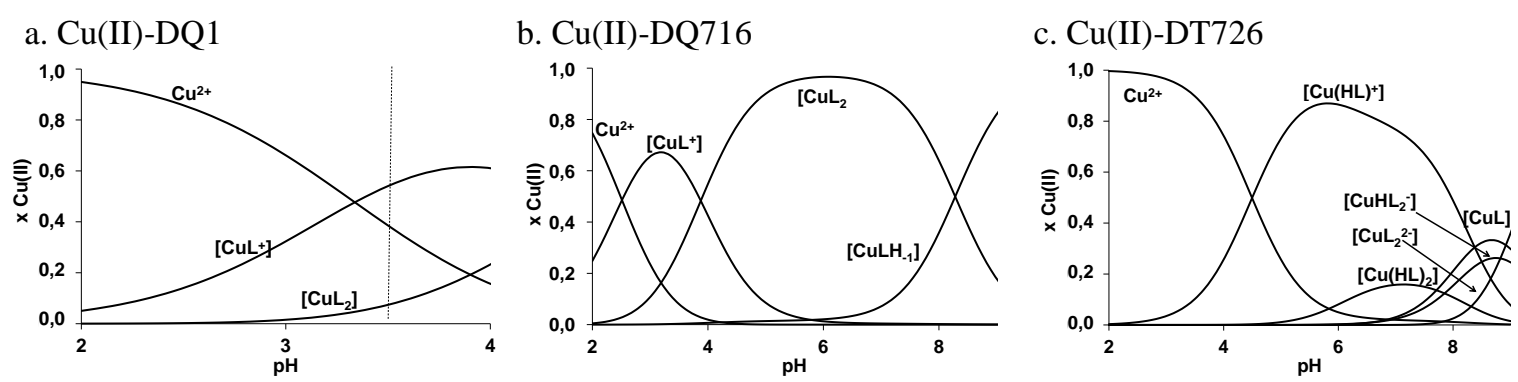

23. ábra: (a.) $\mathrm{Cu}(\mathrm{II})-\mathrm{DQ} 1$, (b.) $\mathrm{Cu}(\mathrm{II})-\mathrm{DQ} 716$ és (c.) $\mathrm{Cu}$ (II)-DT726 rendszerek

$$
\left(\mathrm{c}_{\mathrm{L}}=2 \times 10^{-3} \mathrm{M}, \mathrm{c}_{\mathrm{M}}=5 \times 10^{-4} \mathrm{M}, \mathrm{I}=0,2 \mathrm{M} \mathrm{KCl}, \mathrm{t}=25^{\circ} \mathrm{C}\right)
$$

A DT726 vegyület szintén kis stabilitású komplexet képez $\mathrm{Cu}$ (II)-vel, azonban magasabb ligandum arány mellett a $\mathrm{Cu}(\mathrm{OH})_{2}$ csapadék csak pH 9-nél jelenik meg. Savas tartományban a piridin-N-en protonált ligandum koordinálódik a fémionhoz, lúgosabb tartományban elkezdődik mind a mono, mind a biszkomplex deprotonálódása. Arra vonatkozóan, hogy a protonált piridin-NH, vagy egy koordinálódott vízmolekula deprotonálódásáról van szó, a pH-potenciometria nem ad választ. A legnagyobb mértékü komplexképződést DQ716 ligandumnál tapasztaltunk. pH 2 értéken 1:4 fém ligandum aránynál fémion 28 százaléka komplexben kötött, és a ligandum képes a fémiont megvédeni a hidrolízistől $\mathrm{pH}$ 9-ig. $\mathrm{pH} \quad 6$ felett megkezdődik a monokomplex 
deprotonálódása és $\left[\mathrm{CuLH}_{-1}\right]$ komplex képződése. Feltételezhetően $\left[\mathrm{CuLH}_{-1}\right]$ egy vegyes hidroxidokomplex, melyben a fémionhoz koordinálódott vízmolekula deprotonálódik.

8. táblázat: DQ1, DQ716 és DT726 ligandumok pH-potenciometriás módszerrel meghatározott $\mathrm{Cu}(\mathrm{II})$ és $\mathrm{Zn}(\mathrm{II})$ komplexeinek stabilitási állandói és számolt $\mathrm{K}_{D}$ értéke $(\mathrm{t}=$ $\left.25^{\circ} \mathrm{C}, \mathrm{I}=0,2 \mathrm{M} \mathrm{KCl}\right)^{\mathrm{a}}$

\begin{tabular}{|c|c|c|c|}
\hline & DQ1 $^{b}$ & DQ716 $^{\mathrm{c}}$ & DT726 $^{b}$ \\
\hline $\lg \beta[\mathrm{CuLH}]$ & - & - & $16,08(2)$ \\
\hline $\lg \beta[\mathrm{CuL}]$ & $5,84(5)$ & $6,63(2)$ & 7,6 (1) \\
\hline $\lg \beta\left[\mathrm{CuLH}_{-1}\right]$ & - & $0,84(5)$ & - \\
\hline $\lg \beta\left[\mathrm{CuL}_{2}\right]$ & $10,67(6)$ & $12,03(2)$ & $13,2(1)$ \\
\hline$K_{\mathrm{d}}^{(\mathrm{d})}\left(\mathrm{mol} / \mathrm{dm}^{3}\right)$ & $7,91 \times 10^{-7}$ & $5,48 \times 10^{-9}$ & $3,13 \times 10^{-5}$ \\
\hline $\lg \beta[\mathrm{ZnL}]$ & $3,81(2)$ & $3,91(1)$ & $6,53(2)$ \\
\hline $\lg \beta\left[\mathrm{ZnL}_{2}\right]$ & $6,75(2)$ & $6,92(1)$ & $12,1(1)$ \\
\hline $\lg \beta\left[\mathrm{ZnL}_{3}\right]$ & - & $8,8(1)$ & $16,4(1)$ \\
\hline$K_{\mathrm{d}}^{(\mathrm{d})}\left(\mathrm{mol} / \mathrm{dm}^{3}\right)$ & $3,03 \times 10^{-4}$ & $1,32 \times 10^{-4}$ & $4,45 \times 10^{-3}$ \\
\hline
\end{tabular}

${ }^{\mathrm{a} A}$ zárójelben az állandókra számolt utolsó jegy bizonytalansága van feltüntetve.

${ }^{\mathrm{b}} \mathrm{L}=\left(\mathrm{L}^{2-}\right) ;{ }^{\mathrm{c}} \mathrm{L}=\left(\mathrm{L}^{-}\right)$.

${ }^{\mathrm{d}} K_{\mathrm{D}}=[\mathrm{M}] \operatorname{szabad} \Sigma\left[\mathrm{H}_{x} \mathrm{~L}\right] / \Sigma[\mathrm{M} p \mathrm{H} q \mathrm{Lr}] ; \mathrm{pH}=7,4 \mathrm{c}_{\mathrm{M}}=2,5 \times 10^{-5} \mathrm{M}, \mathrm{c}_{\mathrm{L}}=5,0 \times 10^{-5} \mathrm{M}$

A hidroxi-piridinkarbonsavak Zn(II)ionnal való komplexképződése minden ligandum esetében hasonló speciációt mutat: kis stabilitású mono és biszkomplexek képződnek (6. és 8. táblázat). Triszkomplex képződésére kis koncentrációban csak magasabb fémionligandum arány mellett van lehetőség (24. ábra). A komplexképződés csak $\mathrm{pH}>4$ felett kezdődik meg, és pH 9 után egyik ligandum sem képes megakadályozni a Zn(II)ionok hidrolízisét. 1:4 fémion-ligandum arány mellett még a legerősebb komplexképző ligandum a DQ716 esetében is $\mathrm{Zn}(\mathrm{OH})_{2}$ csapadék válik le az oldatban. A DT726 molekula cinkkomplexe különösen kis stabilitású, a monokomplexe csak pH 6 után jelenik meg az oldatban. 
a. $\mathrm{Zn}(\mathrm{II})-\mathrm{DQ} 5$
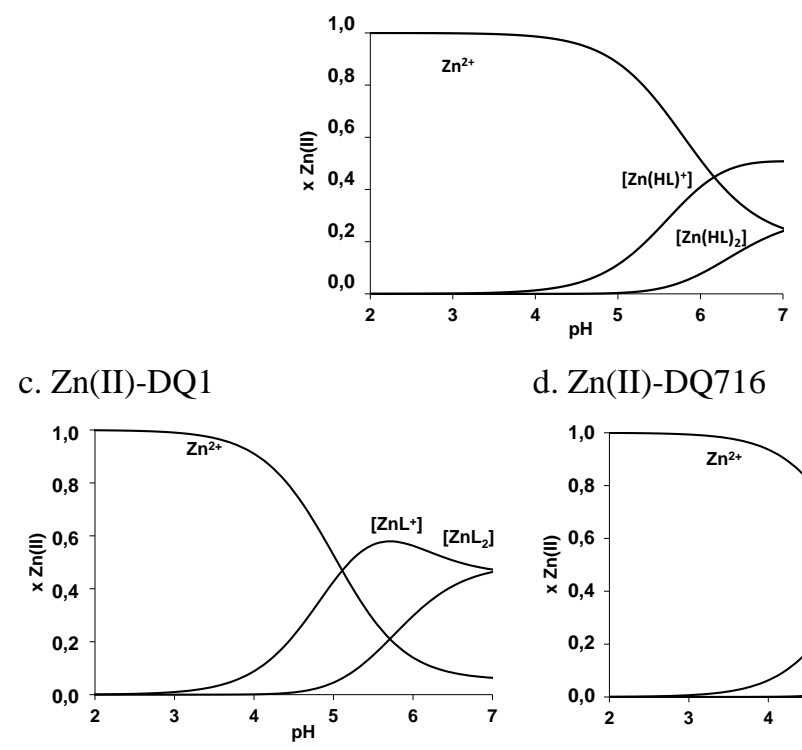

d. Zn(II)-DQ716

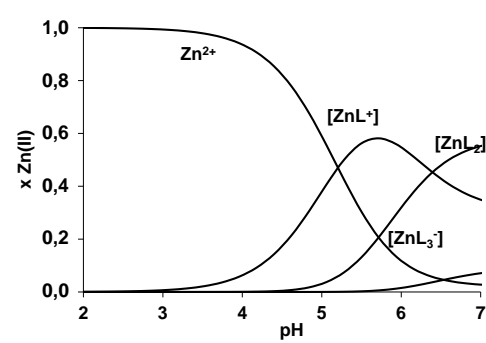

b. Zn(II)-DQ715

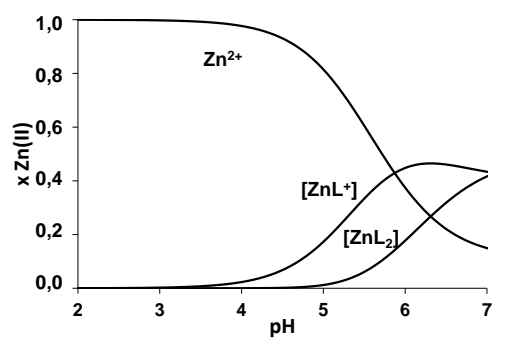

e. Zn(II)-DT726

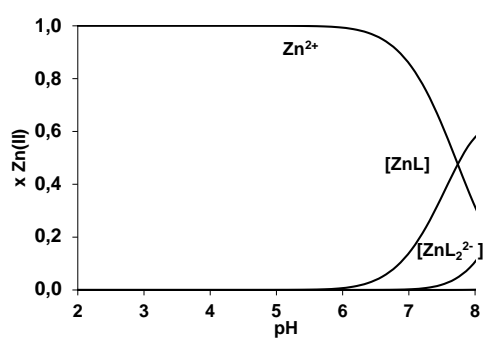

24. ábra: (a.) Zn(II)-DQ5, (b.) Zn(II)-DQ715, (c.) Zn(II)-DQ1, (d.) Zn(II)-DQ716, és

(e.) Zn(II)-DT726 rendszerek koncentrációeloszlási görbéi

(a) $\mathrm{c}_{\mathrm{Zn}(\mathrm{II})}=2,5 \times 10^{-4} \mathrm{M}, \mathrm{c}_{\mathrm{DQ} 5}=1 \times 10^{-3} \mathrm{M} ;(\mathrm{b}, \mathrm{c}, \mathrm{d}, \mathrm{e}) \mathrm{c}_{\mathrm{Zn}(\mathrm{II})}=5 \times 10^{-4} \mathrm{M}, \mathrm{c}_{\mathrm{DQ} 715}=2 \times 10^{-3} \mathrm{M}$;

$$
\left(\mathrm{I}=0,2 \mathrm{M} \mathrm{KCl}, \mathrm{t}=25^{\circ} \mathrm{C}\right)
$$

A komplexképződést a DQ715 ligandum esetében ${ }^{1} \mathrm{H}$ NMR spektroszkópiás módszerrel is vizsgáltuk. A ligandum spektrumainak pH-függését 1:0, 1:1, 1:2 és 1:4 fémion-ligandum arány mellett mértük. A kinetikailag labilis Zn(II)komplexek képződése miatt a komplexképződés során a szabad és a komplexben kötött ligandum között gyors cserefolyamatok játszódnak le, amely jelenség miatt a jelek eltolódását tapasztaltuk. A jelek eltolódásaiból PSEQUAD program segítségével meg tudtuk becsülni a képződő komplexek stabilitási szorzatait, melyek jó egyezést mutatnak a potenciometriás mérések során meghatározott értékekkel. A 25. ábrán a $\mathrm{N}-\underline{\mathrm{CH}}-\mathrm{C}-\mathrm{COO}^{-}$proton jelének mért és számolt ppm értékeit ábrázoltuk a pH függvényében.

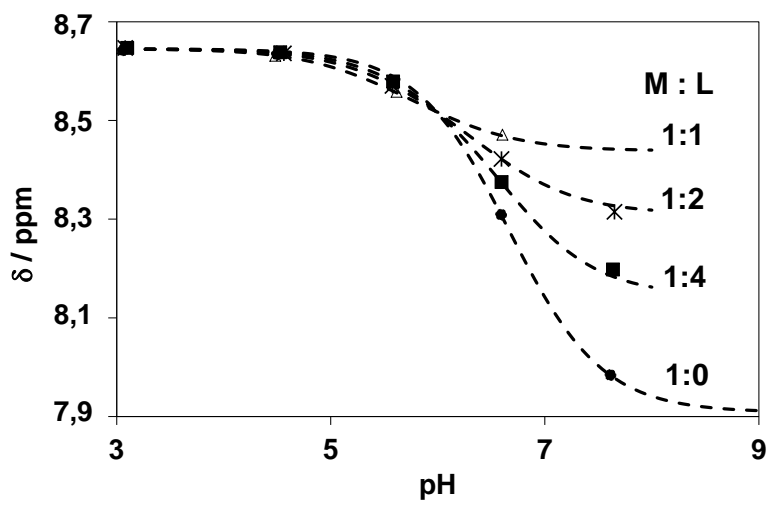

25. ábra: Zn(II)-DQ715 rendszerben a ligandum $\mathrm{N}-\mathrm{CH}-\mathrm{C}-\mathrm{COO}$ hidrogén jelének számolt és mért ${ }^{1} \mathrm{H}$ NMR eltolódásai a pH függvényében $\left(\mathrm{c}_{\mathrm{DQ} 715}=2 \times 10^{-3} \mathrm{M}, \mathrm{I}=0,2 \mathrm{M} \mathrm{KCl}, \mathrm{t}=25^{\circ} \mathrm{C}\right)$ 
A komplexképződés folyamatát UV-látható spektrofotometriás mérésekkel is próbáltuk követni a ligandumhoz rendelhető pH-függő abszorbancia értékek változásai alapján, azonban a kis koncentráció ( $\mu \mathrm{M}$-os tartomány) és a kismértékü komplexképződés miatt a spektrumok változása nem volt értékelhető.

\subsubsection{Legfontosabb következtetések a hidroxi-piridinkarbonsavak komplexképző sajátságairól}

A vizsgált hidroxi-piridinkarbonsav molekulák oldategyensúlyi vizsgálatainak eredményei azt mutatják, hogy egyes ligandumok kelátterápiában való alkalmazása eredményes lehet. Az általunk is vizsgált DQ716 erős komplexképző Fe(III), Al(III) és $\mathrm{Cu}$ (II)ionokkal. $\mathrm{Cu}(\mathrm{II})$ komplexeinek $\mathrm{K}_{D}$ értéke fiziológiás $\mathrm{pH}-\mathrm{n}\left(\mathrm{K}_{D}=5,49 \mathrm{nM}\right)$ abba a tartományba esik, hogy hatékonyan versenghet a $\beta$-amiloid fehérjékben kötött rézionokért. A DQ715 szintén erős komplexképző három vegyértékü fémionokkal. A DQ5 és DQ6 ligandumok elég erös alumínium kelátorok, azonban vas(III) kötő képességük gyengébb. DQ5 Zn(II)- és $\mathrm{Cu}(\mathrm{II})$ ionokkal való vizsgálata azt mutatja a meghatározott $\mathrm{K}_{D}$-érték alapján, hogy a ligandum feltehetően nem befolyásolja a szervezet sem réz- sem cinkháztartását. Így a vizsgálataink alapján ezek a ligandumok alkalmasak lehetnek arra, hogy szelektív alumínium kelátorként alkalmazzák őket. Azonban, bár egyes tanulmányozott ligandumok stabilis komplexet képeznek Fe(III)- és Al(III)ionnal, azok stabilitása nem éri el a klinikumban használt kelátorok M(III)komplexeinek stabilitását (pl. deferipron, dezferrioxamin). A deferipron esetében $\mathrm{pFe}=21,{ }^{194}$ amitől a legerősebb komplexképző hidroxi-piridinkarbonsav értéke is 1,7 lg egységgel elmarad (DT712: pFe = 19,3). ${ }^{195}$ Azaz a deferipronhoz hasonló hatás feltehetően csak nagyobb dózisú hidroxipididinkarbonsav adagolása esetén érhető el. Előnyük azonban ezeknek a ligandumoknak, hogy toxicitásuk in vitro igazoltan nagyon alacsony. Hatékonyabb komplexképzők lehetnek a dihidroxi-piridinkarbonsav származékok, melyekben a két hidroxilcsoport alkalmas helyzetben van pirokatechin-típusú koordinációra az adott fémionnal. 


\subsection{Rákellenes hatású [Ru(II)- $\eta^{6}$-p-cimol] komplexek}

\subsection{1. (O,O) ligandumok oldategyensúlyi viszonyai $\left[\mathrm{Ru}(\mathrm{II})-\eta^{6}-p\right.$-cimol]-lal}

[Ru(II)- $\eta^{6}-p$-cimol] $(\mathrm{O}, \mathrm{O})$ donoratomos ligandummal alkotott komplexei közül a mérsékelt citotoxicitást mutató etil-maltolát és allomaltolát komplexek oldategyensúlyi viszonyait tanulmányoztuk. Etil-maltol esetében kloridos és kloridmentes, míg allomaltolnál kloridos vizes oldatban végeztünk pH-potenciometriás, UV-látható spektrofotometriás és ${ }^{1} \mathrm{H}$ NMR spektroszkópiás méréseket. A harmadik koordinációs helyen lehetséges víz-kloridion egyensúly leírása érdekében a rendszert ${ }^{1} \mathrm{H}$ NMR módszerrel tanulmányoztuk. A meghatározott állandókat a 9. táblázat tartalmazza.

9. táblázat: $\left[\mathrm{Ru}(\mathrm{II})-\eta^{6}-p\right.$-cimol $]-(\mathrm{O}, \mathrm{O})$ komplexek különböző módszerekkel meghatározott stabilitási szorzatai ${ }^{\mathrm{a}}$, proton disszociációs és származtatott állandói

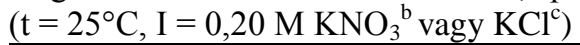

\begin{tabular}{|c|c|c|c|c|}
\hline & & etil-maltol $^{b}$ & etil-maltol ${ }^{\mathrm{c}}$ & allomaltol $^{c}$ \\
\hline \multirow{4}{*}{ } & $\lg \beta[\mathbf{M L}]$ & $10,07(1)$ & $8,95(1)$ & $8,35(1)$ \\
\hline & $\lg \beta\left[\mathrm{MLH}_{-1}\right]$ & - & $-0,53(4)$ & - \\
\hline & $\mathbf{p} K[\mathbf{M L}]=$ & & & \\
\hline & $\lg \beta[\mathrm{ML}]-\lg \beta\left[\mathrm{MLH}_{-1}\right]$ & - & 9,48 & - \\
\hline \multirow{3}{*}{ 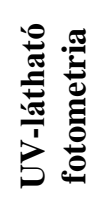 } & $\lg \beta[M L]$ & $10,07(2)$ & $9,01(2)$ & $8,46(3)$ \\
\hline & $\lg \beta\left[\mathrm{MLH}_{-1}\right]$ & - & $-0,49(2)$ & - \\
\hline & $\begin{array}{l}\mathbf{p} \boldsymbol{K}[\mathbf{M L}] \\
\lg \beta[\mathrm{ML}]-\lg \beta\left[\mathrm{MLH}_{1}\right]\end{array}$ & - & 9,50 & - \\
\hline \multirow{2}{*}{ I } & $\mathbf{p K}[\mathrm{ML}]$ & $9,31(1)$ & $9,50(4)$ & $9,32(2)$ \\
\hline & $\lg \mathbf{K}^{\prime}\left(\mathrm{H}_{2} \mathrm{O} / \mathrm{Cl}^{-}\right)^{\mathrm{d}}$ & - & $0,74(2)$ & $0,90(2)$ \\
\hline
\end{tabular}

${ }^{\mathrm{a}} \mathrm{A}$ zárójelben az állandókra számolt utolsó jegy bizonytalansága van feltüntetve.

${ }^{\mathrm{d}}\left[\mathrm{Ru}(\mathrm{II})-\eta^{6}-p-\operatorname{cimol}(\mathrm{L})\left(\mathrm{H}_{2} \mathrm{O}\right)\right]^{+}+\mathrm{Cl}^{-} \rightleftharpoons\left[\mathrm{Ru}(\mathrm{II})-\eta^{6}-p-\operatorname{cimol}(\mathrm{L}) \mathrm{Cl}\right]+\mathrm{H}_{2} \mathrm{O}$ (változó kloridkoncentráció mellett)

\subsubsection{1. $\left[\operatorname{Ru}(I I)-\eta^{6}-p\right.$-cimol]-etil-maltol rendszer tanulmányozása kloridmentes kö-} zegben

Etil-maltol komplexképző tulajdonságát [Ru(II)- $\eta^{6}-p$-cimol]-lal kloridmentes közegben pH-potenciometriásan, UV-látható spektrofotometriásan és ${ }^{1} \mathrm{H}$ NMR spektroszkópiásan vizsgáltuk 0,2 M-os $\left(\mathrm{KNO}_{3}\right)$ ionerősség mellett. A komplexképződés már $\mathrm{pH}<2$-nél elkezdődik, és a rendszerben csak monokomplexek képződnek. Az $[\mathrm{ML}]^{+}$komplex stabilitási állandóját pH-potenciometriás és UV-látható spektrofotometriás mérésekkel határoztuk meg, utóbbi esetben követve a töltésátviteli sávok változásait a $\mathrm{pH}$ függvényében. A két módszerrel meghatározott stabilitási állandók jó egyezést mutatnak egymással. Feltételezésünk szerint a kialakult monokomplexben az etil-maltol ligandum 
$(\mathrm{O}, \mathrm{O})$ kétfogú módon koordinálódik a $\left[\mathrm{Ru}(\mathrm{II})-\eta^{6}-p\right.$-cimol]-hoz, mint ahogy azt korábban Kandioller és mtsai. röntgendiffrakciós módszerrel meghatározták más maltolszámazékok esetén szilárd fázisban. ${ }^{144} \mathrm{~A}\left[\mathrm{Ru}(\mathrm{II})-\eta^{6}-p\right.$-cimol] harmadik koordinációs helyén kloridmentes közegben pH 7 alatt feltehetően víz molekula koordinálódik.

A lúgos közegben lejátszódó folyamatok megértését az ${ }^{1} \mathrm{H}$ NMR spektroszkópiás méréseink nagymértékben segítették (26. ábra). Az NMR időskálához képest lassú cserefolyamatok miatt jól elkülöníthetök a szabad és komplexben kötött ligandum, illetve [Ru(II)- $\eta^{6}-p$-cimol] protonjainak jelei. A különböző módszerrel felvett spektrumok változásai tisztán mutatják, hogy $\mathrm{pH} 8,8$ felett két átfedő folyamat játszódik le. Egyrészt vegyes-hidroxidokomplex $\left[\mathrm{MLH}_{-1}\right]$ képződik, ami a $[\mathrm{ML}]^{+}$komplex jeleinek diamágneses eltolódását eredményezi, másrészt a $\left[\mathrm{Ru}(\mathrm{II})-\eta^{6}-p\right.$-cimol(L)] komplex a

$$
\left.2\left[\mathrm{Ru}(\mathrm{II})-\eta^{6}-p \text {-cimol }\right)(\mathrm{L})\left(\mathrm{H}_{2} \mathrm{O}\right)\right]^{+}+3 \mathrm{OH}^{-} \rightleftharpoons\left[\left(\mathrm{Ru}(\mathrm{II})-\eta^{6}-p-\mathrm{cimol}\right)_{2}(\mathrm{OH})_{3}\right]^{+}+2 \mathrm{~L}^{-}+2 \mathrm{H}_{2} \mathrm{O}
$$

folyamat szerint disszociál, és a kétmagvú $\left[\mathrm{M}_{2} \mathrm{H}_{-3}\right]$ komplex, illetve a szabad ligandum jelenik meg a rendszerben.

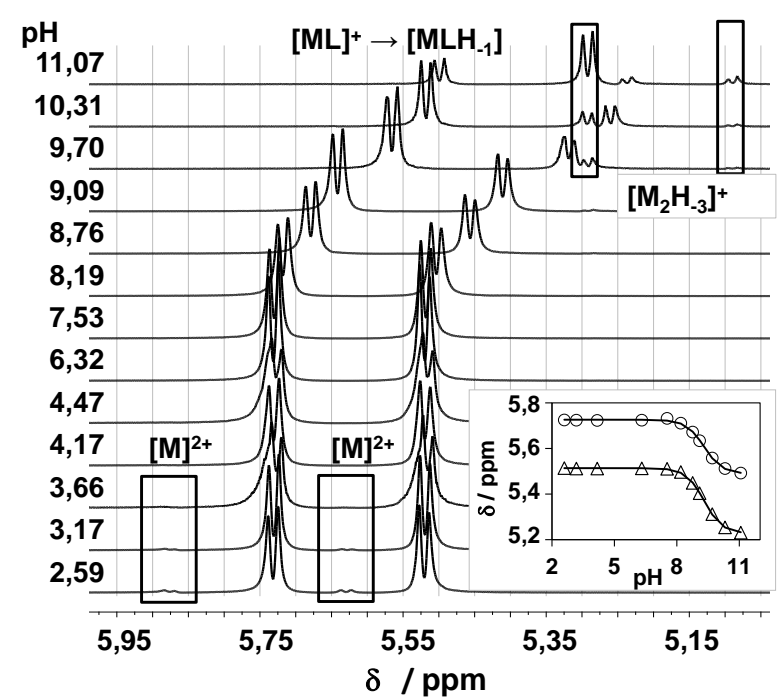

26. ábra: $\left[\mathrm{Ru}(\mathrm{II})-\eta^{6}-p\right.$-cimol]-etil-maltol 1:1 arányú rendszer $\mathrm{pH}$-függő ${ }^{1} \mathrm{H}$ NMR spektrumai a

$\left[\mathrm{Ru}(\mathrm{II})-\eta^{6}-p\right.$-cimol] aromás protonjaihoz tartozó jelek kémiai eltolódásnak tartományában.

A beszúrt diagram a ${ }^{1} H$ NMR spektrumok adatai alapján meghatározott komplexben lévö

[Ru(II)- $\eta^{6}$-p-cimol]-hoz tartozó CH(Ar) csoport jeleinek eltolódásait mutatja a pH függvényében $(\circ, \Delta$ : mért, folytonos vonal: meghatározott $p K[M L]$ alapján illesztett $)$.

$\left(c_{\mathrm{L}}=\mathrm{c}_{\mathrm{M}}=1,0 \times 10^{-3} \mathrm{M}, \mathrm{I}=0,2 \mathrm{M} \mathrm{KNO}_{3}, \mathrm{t}=25^{\circ} \mathrm{C}, 10 \% \mathrm{D}_{2} \mathrm{O}\right)$

Ez utóbbi folyamat feltételezésünk szerint lassú, a mérési időtartam alatt az egyensúly nem áll be a rendszerben, ezért a folyamatot pH-metriás úton, a mérési körülményeink között nem tudtuk követni. Az $[\mathrm{ML}]^{+}$komplex pK-jának becslése a pH-függő ${ }^{1} \mathrm{H}$ NMR spektrumok változásán alapult. A $\mathrm{CH}(A r)$-arén protonok eltolódásaiból számolt pK-érték (pK $=9,31 \pm 0,01)$ jó egyezést mutat az irodalomban korábban meghatározott értékkel $(9,12) .{ }^{143,144}$ 


\subsubsection{2. $\left[R u(I I)-\eta^{6}-p-c i m o l\right]-e t i l-m a l t o l$ és $\left[R u(I I)-\eta^{6}-p-c i m o l\right]-a l l o m a l t o l$ rendszer}

\section{tanulmányozása kloridiont tartalmazó közegben}

Mint ahogy az korábbi fejezetekben már többször említetésre került, a kloridion koordinálódni képes a [Ru(II)- $\eta^{6}-p$-cimol] szabad koordinációs helyeire, így szerepét a komplexképződési folyamatokban nem lehet elhanyagolni. Etil-maltol és allomaltol ligandumok esetében a komplexképződés kloridion jelenlétében $\left[\left(\mathrm{Ru}(\mathrm{II})-\eta^{6}-p \text {-cimol }\right) \mathrm{X}_{3}\right]^{\mathrm{n}}$-lal $\left(\mathrm{X}=\mathrm{H}_{2} \mathrm{O}\right.$ vagy $\mathrm{Cl}^{-} \mathrm{n}={ }^{-} 1-^{+} 2$; a töltés feltüntetését a későbbiekben az egyszerüség kedvéért elhanyagoljuk)) sok tekintetben hasonló, mint nitrátos közegben: [ML] és $\left[\mathrm{MLH}_{-1}\right]$ részecske képződését tapasztaltuk. Azonban néhány különbség is észrevehető. Figyelembe kell vennünk, hogy a $\left[\left(\mathrm{Ru}(\mathrm{II})-\eta^{6}-p\right.\right.$-cimol $\left.) \mathrm{X}_{3}\right]$ és a $\left[\mathrm{Ru}(\mathrm{II})-\eta^{6}-p\right.$-cimol(L)X] komplexekben a koordinálódott vízmolekula kloridionra cserélődhet, ezért az általunk meghatározott állandók látszólagos stabilitási állandók, melyek csak az adott körülmények között érvényesek $\left(0,2 \mathrm{M} \mathrm{KCl}, \mathrm{t}=25^{\circ} \mathrm{C}\right)$. Másrészt a kloridion, mint „versengő” ligandum, hatással van [ML] komplex stabilitására is.

A képződő komplexek összetételét és stabilitási állandóit pH-potenciometriás, illetve UV-látható spektrofotometriás úton határoztuk meg (27. ábra).

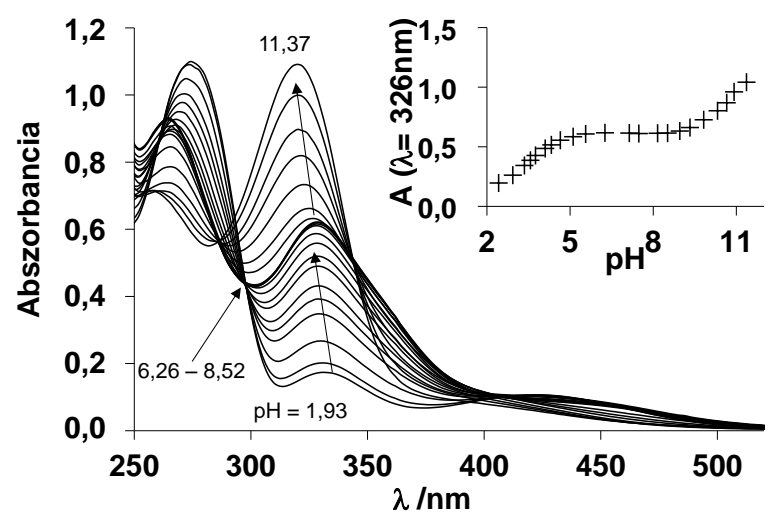

27. ábra: $\left[\mathrm{Ru}(\mathrm{II})-\eta^{6}-p\right.$-cimol]-etil-maltol rendszer $\mathrm{pH}$-függő, hígítással korrigált UV-látható spektrumai $\mathrm{pH}=1,9-11,4$ tartományban.

A beszúrt diagram az abszorbancia változását mutatja a $p H$-függvényében $\lambda=326$ nm-en .

$\left(\mathrm{c}_{\mathrm{L}}=\mathrm{c}_{\mathrm{M}}=1,0 \times 10^{-4} \mathrm{M}, \mathrm{I}=0,2 \mathrm{M} \mathrm{KCl}, \mathrm{t}=25^{\circ} \mathrm{C}\right)$

A nitrátos közegben végzett méréseinkhez hasonlóan, a komplexképződést kloridion jelenlétében ${ }^{1} \mathrm{H}$ NMR mérésekkel is tanulmányoztuk. Az 1:1 fémion-ligandum arány mellett mért $\left[\mathrm{Ru}(\mathrm{II})-\eta^{6}-p\right.$-cimol]-allomaltol rendszer reprezentatív pH-függő ${ }^{1} \mathrm{H} \mathrm{NMR}$ spektrumait a 28. ábra mutatja. 


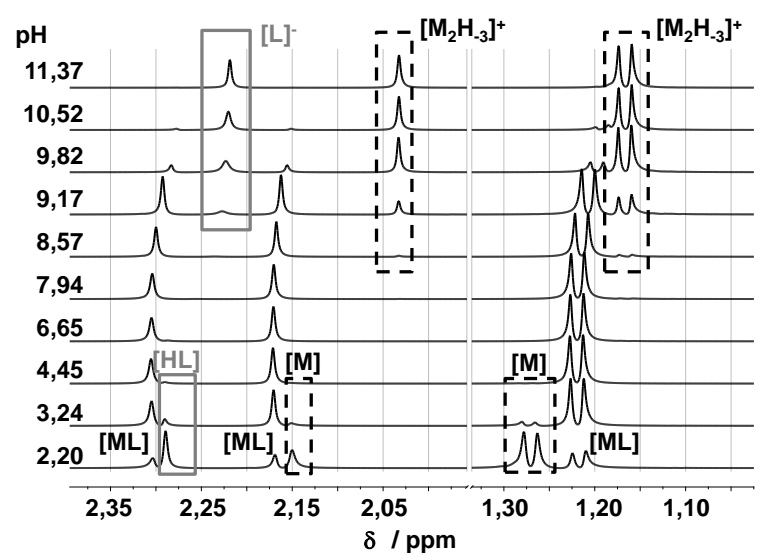

28. ábra: $\left[\mathrm{Ru}(\mathrm{II})-\eta^{6}-p\right.$-cimol]-allomaltol 1:1 arányú rendszer $\mathrm{pH}$ függő ${ }^{1} \mathrm{H}$ NMR spektrumainak alifás régiója $\left(\mathrm{c}_{\mathrm{L}}=\mathrm{c}_{\mathrm{M}}=2,0 \times 10^{-3} \mathrm{M}, \mathrm{I}=0,2 \mathrm{M} \mathrm{KCl}, \mathrm{t}=25^{\circ} \mathrm{C}, 10 \% \mathrm{D}_{2} \mathrm{O}\right)$

A spektrumokon mindkét rendszerben az [ML] komplex képződését jelző csúcsok már pH 2 alatt felismerhetők, de még pH 4 felett is azonosítani lehet a szabad ligandum, illetve $\left[\mathrm{Ru}(\mathrm{II})-\eta^{6}-p\right.$-cimol]-hoz rendelhető jeleket. A kötött és nem kötött ligandum, illetve $\left[\mathrm{Ru}(\mathrm{II})-\eta^{6}-p\right.$-cimol] rész protonjaihoz rendelhető jelek a spektrumokon jól elkülönülnek, így az egyes részecskékhez tartozó jel alatti területekből információt nyerhetünk azok arányáról. A számított móltörtek alapján szintén megállapítható, hogy kloridion jelenlétében az [ML] komplex aránya kevesebb, mint annak hiányában, amiből arra következtetünk, hogy a kialakult komplex stabilitása valamivel kisebb ebben a környezetben. A pH-potenciometriás mérésekből számolt stabilitási állandók alapján meghatároztuk a szabad fém és a komplex arányát a $\mathrm{pH}$-függvényében az ${ }^{1} \mathrm{H} \mathrm{NMR}$ mérések során alkalmazott körülmények között, és összevetettük az ${ }^{1} \mathrm{H}$ NMR spektrumok alapján becsült értékekkel.

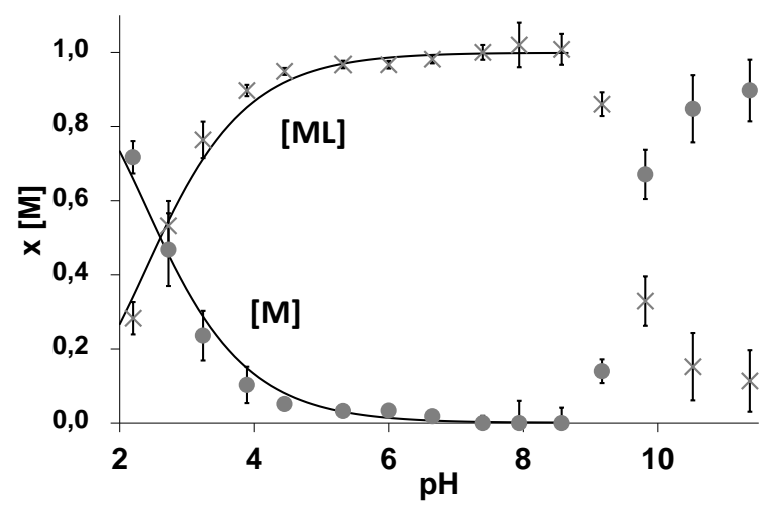

29. ábra: $\left[\mathrm{Ru}(\mathrm{II})-\eta^{6}-p\right.$-cimol] $\mathrm{CH}_{3}$ and $i \mathrm{Pr}-\mathrm{CH}_{3}$ protonjaihoz rendelhető jelek integráljai alapján számolt kötött $(\times)$ és szabad $(\bullet)\left[R u(I I)-\eta^{6}-p\right.$-cimol] móltörtjeinek arányai, és $\left[R u(I I)-\eta^{6}-p\right.$-cimol(Z) 3$]$-allomaltol rendszer koncentrációeloszlás diagramja a pH-potenciometriás mérések során meghatározott stabilitási állandók alapján (folytonos vonal); $\left(\mathrm{Z}=\mathrm{H}_{2} \mathrm{O}\right.$ vagy $\left.\mathrm{Cl}^{-}\right)$
$\left(\mathrm{c}_{\mathrm{L}}=\mathrm{c}_{\mathrm{M}}=2 \times 10^{-3} \mathrm{M}, \mathrm{I}=0,2 \mathrm{M} \mathrm{KCl}, \mathrm{t}=25^{\circ} \mathrm{C}, 10 \% \mathrm{D}_{2} \mathrm{O}\right)$

A 29. ábra azt mutatja, hogy allomaltol esetén két mérés $\mathrm{pH}$-ig jó egyezést mutat, a felett azonban jelentősen eltér. A különbség oka valószínüleg az $\left[\mathrm{M}_{2} \mathrm{H}_{-3}\right]$ megjelenéséhez, 
azaz az [ML] komplex disszociációjához köthető, ami kinetikailag lassú folyamat, így a pH-metriás mérések során lúgosabb pH-tartományban az egyensúly nem teljes, így annak kiértékelése nem lehetséges. Etil-maltol esetében a disszociáció némileg magasabb pH-n kezdődik. Az $\left[\mathrm{M}_{2} \mathrm{H}_{-3}\right]$ jele csak pH 9 felett jelenik meg, így lehetőség van az $\left[\mathrm{MLH}_{-1}\right]$ stabilitási állandójának meghatározására pH-metriás, UV-látható fotometriás mérésekből is, úgy hogy adatainkat $\mathrm{pH}$ 9-ig vesszük figyelembe.

$\mathrm{Az}$ [ML] komplexek deprotonálódását jellemző $\mathrm{pK}$-értéket az ${ }^{1} \mathrm{H}$ NMR-méréseink alapján becsülni tudtuk etil-maltollal és allomaltollal képzett komplexek esetében is a komplexben lévő cimol rész aromás protonjainak eltolódásaiból (9. táblázat).

Azért, hogy meggyőződjünk arról, hogy biszkomplex nem képződik, ligandum felesleg mellett vizsgáltuk az ${ }^{1} \mathrm{H}$ NMR spektrumok változását a $\mathrm{pH}$ függvényében. Ezeken a spektrumokon (melléklet - M3) csupán olyan jeleket tudtunk azonosítani, melyet már az 1:1 fémion:ligandum arány mellett rögzített spektrumok is mutattak, biszkomplex jelenlétére utaló csúcs nem jelenik meg a spektrumokon, így annak jelenlétét kizárhatjuk.

Ha összehasonlítjuk az allomaltol és az etil-maltol [ML] komplexeinek stabilitási szorzatait az irodalomban közölt $\left[\mathrm{Ru}(\mathrm{II})-\eta^{6}-p\right.$-cimol] maltollal alkotott komplexével, a stabilitási állandók a

$$
\lg \beta[\mathrm{ML}]_{\text {allomaltol }}(8,35)<\lg \beta[\mathrm{ML}]_{\text {etil-maltol }}(8,95)<\lg \beta[\mathrm{ML}]_{\text {maltol }}(9,05)
$$

trendet mutatják. A ligandumok eltérő bázicitása miatt valójában a stabilitási állandók ( $\lg \beta[\mathrm{ML}])$ értékei közvetlenül nem összevethetők, így pontosabb képet akkor kapunk a komplexek stabilitásáról, ha azok bázicitással korrigált stabilitási állandóit hasonlítjuk össze. A

$$
\begin{gathered}
{\left[\mathrm{Ru}(\mathrm{II})-\eta^{6}-p-\operatorname{cimol}(\mathrm{Z})_{3}\right]+\mathrm{HL} \rightleftharpoons\left[\mathrm{Ru}(\mathrm{II})-\eta^{6}-p-\operatorname{cimol}(\mathrm{L})(\mathrm{Z})\right]+\mathrm{H}^{+}+2 \mathrm{X}} \\
\left(\mathrm{Z}=\mathrm{H}_{2} \mathrm{O} \text { vagy } \mathrm{Cl}^{-}\right) \text {folyamatra számolt } \\
\lg \mathrm{K}^{\prime}=\lg \beta[\mathrm{ML}]-\mathrm{pK}(\mathrm{HL})
\end{gathered}
$$

érték a komplexképződés során az [ML] képződésére számolható származtatott állandó, melyben a komplex stabilitási szorzatának értékét a ligandum fenolos csoportjának bázicitásával korrigáltuk. Minél nagyobb a $\lg \mathrm{K}$ ' állandó, annál stabilisabb a képződő komplex. A lg K' származtatott állandók a már említett trendet támasztják alá:

$$
\lg \mathrm{K}^{\prime} \text { allomaltol }(0,38)<\lg \mathrm{K}^{\prime} \text { etil-maltol }(0,45)<\lg \mathrm{K}^{\prime} \text { maltol }(0,60) \text {. }
$$

A stabilitási sorrendből úgy tünik, a gyürün lévő metilcsoport helyzete hatással van a speciációra, az allo-származék [Ru(II)- $\eta^{6}-p$-cimol]-lal alkotott komplexe kisebb stabilitású. Hasonló következtetéseket vontak le az allomaltol Ga(III)-al képzett komplexére is. ${ }^{179}$ 
Másrészről a metilcsoport etilcsoportra történő cseréje szintén kismértékü stabilitás csökkenést eredményez. Irodalmi adatok alapján megállapíthatjuk azt is, hogy a maltol, illetve általunk vizsgált származékok [Ru(II)- $\eta^{6}-p$-cimol] komplexeinek stabilitása a 3,4hidroxipiridinonoknál kisebb, ${ }^{181}$ míg a 3-hidroxi-2-piridinin származé-kokénál nagyobb. ${ }^{196}$

Kloridmentes közegben a $\left[\mathrm{Ru}(\mathrm{II})-\eta^{6}-p-\operatorname{cimol}(\mathrm{L})\left(\mathrm{H}_{2} \mathrm{O}\right)\right]^{+}$komplexekben a harmadik koordinációs helyre vízmolekula koordinálódik. Kloridion koncentrációtól függően azonban a koordinálódott vízmolekulát a kloridion kiszoríthatja, vagy fordítva: az eredetileg kloridokomplexben a kloridion helyére képes vízmolekula koordinálódni. A gyors klorid-akva cserefolyamat miatt a $\left[\mathrm{Ru}(\mathrm{II})-\eta^{6}-p\right.$ - $\left.\operatorname{cimol}(\mathrm{L})(\mathrm{Cl})\right]$ és $\left[\mathrm{Ru}(\mathrm{II})-\eta^{6}-p-\right.$ $\left.\operatorname{cimol}(\mathrm{L})\left(\mathrm{H}_{2} \mathrm{O}\right)\right]^{+}$komplexek jelei az ${ }^{1} \mathrm{H}$ NMR spektrumokon nem különülnek el egymástól, így kiátlagolt jeleket kapunk. Azonban az oldat kloridion koncentrációját változtatva, az egyes csoportokra jellemző kémiai eltolódások értékeinek változásaiból következtethetünk az akva/klorido komplexek arányára. Ezért követtük az ML komplex spektrális tulajdonságainak változását a kloridion koncentrációt változtatva $\mathrm{pH}=3,50(\mathrm{~L}=$ etil-maltol) és $\mathrm{pH}=5,50$-nél $(\mathrm{L}=$ allomaltol) (30. ábra). (Az oldatok pH-értékét úgy választottuk meg, hogy az adott pH-n az [ML] komplex közel $100 \%$-ban legyen jelen.) Az oldatok kloridion tartalmát növelve az NMR jelek eltolódásiban, egy kismértékü, de jól követhető változás volt megfigyelhető, ami a

$$
\left[\mathrm{Ru}(\mathrm{II})-\eta^{6}-p-\operatorname{cimol}(\mathrm{L})\left(\mathrm{H}_{2} \mathrm{O}\right)\right]^{+}+\mathrm{Cl}^{-} \rightleftharpoons\left[\mathrm{Ru}(\mathrm{II})-\eta^{6}-p-\operatorname{cimol}(\mathrm{L})(\mathrm{Cl})\right]+\mathrm{H}_{2} \mathrm{O}
$$

folyamathoz köthetö.

A kémiai eltolódások változásaiból lépcsőzetes stabilitási állandót becsültünk a víz/ $\mathrm{Cl}^{-}$ ko-ligandumok cserefolyamatainak jellemzésére. Ez alapján az etil-maltol $\left[\operatorname{Ru}(\mathrm{II})-\eta^{6}-p\right.$ cimol(L)(Cl)] komplexeinek aránya $0,1 \mathrm{M}^{*}$ illetve $0,2 \mathrm{M}$ kloridkoncentráció esetében $36 \%$ illetve $52 \%$-ban vannak jelen, míg allomaltol esetében a becsült érték $44 \%$ illetve $66 \%$ a vizsgált $\mathrm{pH}$-értéken *

\footnotetext{
* a vérplazma kloridion koncentrációja kb. 0,1 M
} 
a.

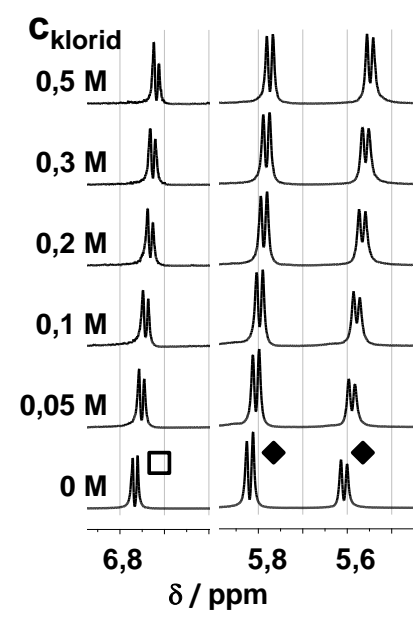

b.

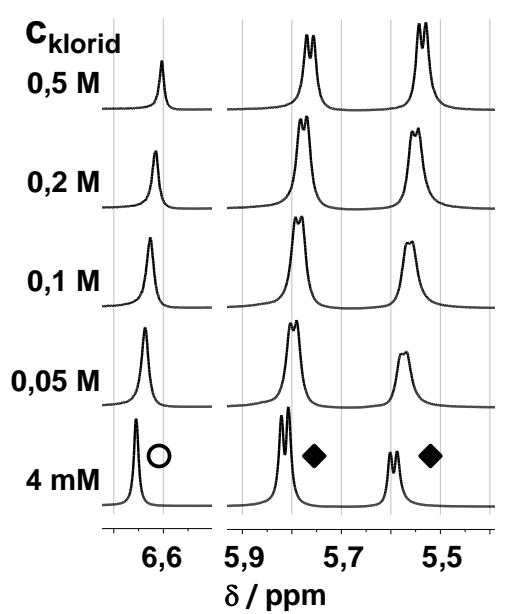

30. ábra: $\left[\mathrm{Ru}(\mathrm{II})-\eta^{6}-p\right.$-cimol]-etil-maltol $(\mathrm{pH}=3,5)$ (a) és allomaltol $(\mathrm{pH}=5,5)$ (b) rendszer ${ }^{1} \mathrm{H}$ NMR spektrumainak aromás régiója változó kloridion koncentráció mellett. Ligandumok: $\square, \circ$ és [Ru(II)- $\eta^{6}-p$-cimol]: $\downarrow$ aromás protonjainak jelei; $\left(\mathrm{c}_{\mathrm{L}}=\mathrm{c}_{\mathrm{M}}=2 \times 10^{-3} \mathrm{M}, \mathrm{t}=25^{\circ} \mathrm{C}, 10 \% \mathrm{D}_{2} \mathrm{O}\right)$

\subsection{2. (O,N) ligandumok oldategyensúlyi viszonyai $\left[\mathrm{Ru}(\mathrm{II})-\eta^{6}-p\right.$-cimol]-lal}

A [Ru(II)- $\eta^{6}$-p-cimol]-pikolinsav komplexe, melynek röntgenszerkezetét az irodalmi bevezetőben már bemutattuk (12. ábra), rákellenes aktivitást mutat. Hasonlóan az $(\mathrm{O}, \mathrm{O})$ donoratomos rendszereinkhez vizsgáltuk az $\left[\mathrm{Ru}(\mathrm{II})-\eta^{6}-p-\operatorname{cimol}(\mathrm{O}, \mathrm{N})(\mathrm{Z})\right]$ rendszerek oldategyensúlyi viszonyait kloridos, illetve pik esetén kloridmentes, nitrátos vizes közegben.

10. táblázat: $\left[\mathrm{Ru}(\mathrm{II})-\eta^{6}-p\right.$-cimol $]-(\mathrm{O}, \mathrm{N})$ komplexek különböző módszerekkel meghatározott stabilitási szorzatai ${ }^{\mathrm{a}}$, proton disszociációs és származtatott állandói $(\mathrm{t}=$ $25^{\circ} \mathrm{C}, \mathrm{I}=0,20 \mathrm{M} \mathrm{KNO}_{3}{ }^{\mathrm{b}}$ vagy $\mathrm{KCl}^{\mathrm{c}}$ )

\begin{tabular}{|c|c|c|c|c|c|}
\hline & & pik $^{\mathbf{b}}$ & pik $^{c}$ & 6-Mepik ${ }^{c}$ & $\operatorname{dipik}^{c}$ \\
\hline \multirow{6}{*}{ 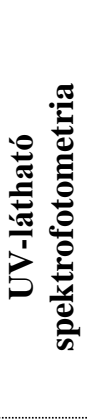 } & $\lg \beta[$ MLH $]$ & - & - & - & $12,4(3)$ \\
\hline & $\lg \beta[\mathrm{ML}]$ & $8,90(1)$ & $8,14(1)$ & $7,44(1)$ & $11,25(9)$ \\
\hline & $\lg \beta\left[\mathbf{M L H}_{-1}\right]$ & $0,90(2)$ & $-0,76(2)$ & $-1,63(4)$ & $2,40(5)$ \\
\hline & $\begin{array}{l}\mathbf{p K}[\mathbf{M L H}]= \\
\lg \beta[\mathrm{MLH}]-\lg \beta[\mathrm{ML}]\end{array}$ & - & - & - & 1,15 \\
\hline & $\begin{array}{l}\mathbf{p K}[\mathbf{M L}]= \\
\lg \beta[\mathrm{ML}]-\lg \beta\left[\mathrm{MLH}_{-1}\right]\end{array}$ & 8,00 & 8,90 & 9,07 & 8,90 \\
\hline & $\begin{array}{l}\operatorname{lgK} \mathbf{K}^{\prime}[\mathbf{M L}]= \\
\lg \beta[\mathrm{ML}]-\mathrm{pK}_{\mathrm{a}}(\mathrm{HL})\end{array}$ & 3,75 & 2,97 & 1,62 & $4,65^{\mathrm{d}}$ \\
\hline \multirow{2}{*}{ 斈 } & $\lg \beta\left[\mathbf{M L H}_{-1}\right]$ & $0,86(2)$ & $-0,75(2)$ & $-1,60(3)$ & $2,27(5)$ \\
\hline & $\begin{array}{l}\mathbf{p K}[\mathbf{M L}]= \\
\lg \beta[\mathrm{ML}]-\lg \beta\left[\mathrm{MLH}_{-1}\right]\end{array}$ & 8,04 & 8,90 & 9,04 & 8,98 \\
\hline \multirow{2}{*}{$\Xi \mathscr{z}$} & pK $[\mathrm{ML}]$ & 8,10 & - & - & - \\
\hline & $\lg \mathbf{K}^{*}\left(\mathrm{H}_{2} \mathrm{O} / \mathrm{Cl}^{-}\right)^{\mathrm{e}}$ & - & $1,83(6)$ & $1,45(5)$ & $0,7(1)$ \\
\hline
\end{tabular}

${ }^{a} A$ zárójelben az állandókra számolt utolsó jegy bizonytalansága van feltüntetve.

${ }^{\mathrm{d}} \lg \beta[\mathrm{ML}]-\mathrm{pK}_{\mathrm{a}}(\mathrm{HL})-\mathrm{pK}_{\mathrm{a}}\left(\mathrm{H}_{2} \mathrm{~L}\right)$

${ }^{\mathrm{e}}\left[\mathrm{Ru}(\mathrm{II})-\eta^{6}-p-\operatorname{cimol}(\mathrm{L})\left(\mathrm{H}_{2} \mathrm{O}\right)\right]^{+}+\mathrm{Cl}^{-} \rightleftharpoons\left[\mathrm{Ru}(\mathrm{II})-\eta^{6}-p-\operatorname{cimol}(\mathrm{L}) \mathrm{Cl}\right]+\mathrm{H}_{2} \mathrm{O}$ (változó kloridkoncentráció mellett) 


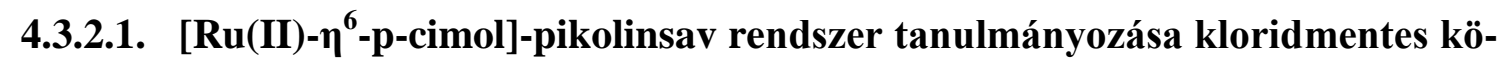 zegben}

A pH-potenciometriás méréseink alapján a titrálási görbék kezdeti szakaszából megállapítottuk, hogy [Ru(II)- $\eta^{6}-p$-cimol]-pikolinsav rendszer esetében már pH 2 alatt szinte teljes a protonleszorítás a ligandumról, azaz a komplexképződés szinte teljesnek mondható. Ezért a képződő $[\mathrm{ML}]^{+}$komplex stabilitási állandóit pH-függő UV-látható spektrofotometriás mérésekkel határoztuk meg pH 2 alatti egyedi minták mérésével és titrálás kombinációjával. A pH = 0,7-1,8-as tartományban az oldat $\mathrm{pH}$-ját a minta erős sav tartalma alapján számoltuk. A pH csökkenésével a minta $\mathrm{KNO}_{3}$ tartalmát $\mathrm{HNO}_{3}$-ra cseréltük, így az ionerősség a pH 2 alatti tartományban is $0,2 \mathrm{M}$ maradt, míg pH 2-11 között titrálás során rögzítettük az abszorpciós spektrumokat. (31. ábra).

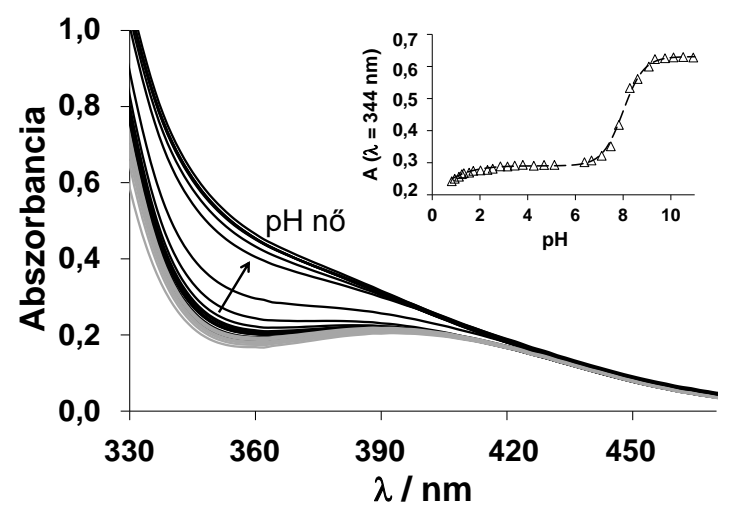

31. ábra: $A\left[R u(I I)-\eta^{6}-p\right.$-cimol]-pikolinsav rendszer $\mathrm{pH}$-függő UV-látható spektrumai. A szürkével jelölt rész a pH 0,8-2 tartományban felvett egyedi minták spektrumai, a fekete görbék a titrálás folyamán $\mathrm{pH}$ 2-11 között felvett, hígítással korrigált abszorbancia spektrumai.

A beszúrt diagram az abszorbancia változását mutatja a pH-függvényében $\lambda=344 \mathrm{~nm}$-en a számolt állandó alapján illesztett görbével együtt (szaggatott vonal). $\left(\mathrm{c}_{\mathrm{L}}=\mathrm{c}_{\mathrm{M}}=3,2 \times 10^{-4} \mathrm{M}, \mathrm{I}=0,2 \mathrm{M} \mathrm{KNO}_{3} / \mathrm{HNO}_{3}, \mathrm{t}=25^{\circ} \mathrm{C}\right)$

Az értékelés során 330-500 nm hullámhossz tartományát vettük figyelembe ahol sem ligandumnak, sem a nitrátionnak nincs fényelnyelése. A fotometriás mérések lúgos tartományban felvett spektrumaiból meghatároztuk a $\left[\mathrm{MLH}_{-1}\right] \lg \beta$-értékét is. A fotometriás mérések savas tartományából számolt $[\mathrm{ML}]^{+}$komplex $\lg \beta$-értékét $(8,9)$ rögzítve a potenciometriás mérések lúgos tartományából meg tudtuk határozni $\left[\mathrm{MLH}_{-1}\right]$ komplex stabilitási szorzatát.

A pH-potenciometriás és UV-látható fotometriás méréseinket ${ }^{1} \mathrm{H}$ NMR mérésekkel egészítettük ki (32. ábra). 


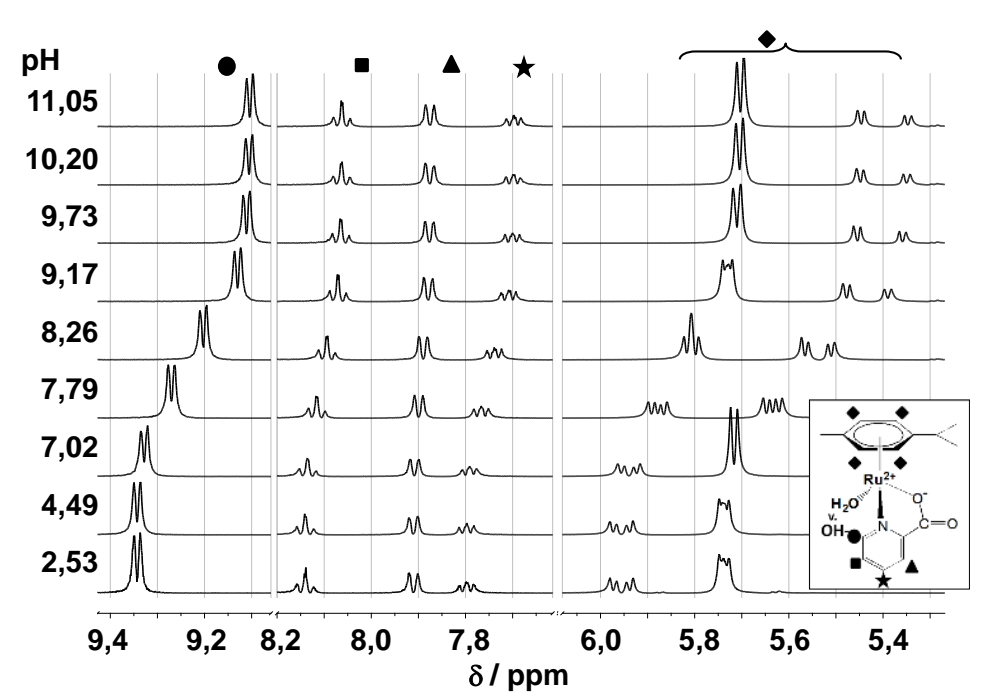

32. ábra: [Ru(II)- $\eta^{6}-p$-cimol] $]$-pikolinsav 1:1 fémion-ligandum arányú rendszer $\mathrm{pH}$ függö ${ }^{1} \mathrm{H}$ NMR spektrumai a ligandum aromás protonjaihoz tartozó jelek kémiai eltolódásnak tartományában.

$$
\left(\mathrm{c}_{\mathrm{L}}=\mathrm{c}_{\mathrm{M}}=1,0 \times 10^{-3} \mathrm{M}, \mathrm{I}=0,2 \mathrm{M} \mathrm{KNO}_{3}, \mathrm{t}=25^{\circ} \mathrm{C}, 10 \% \mathrm{D}_{2} \mathrm{O}\right)
$$

A savas $\mathrm{pH}$ tartományban felvett spektrumokon a szabad ligandum, illetve $\left[\mathrm{Ru}(\mathrm{II})-\eta^{6}-p\right.$ cimol] jelei nem, vagy csak alig észrevehetők, megerősítve ezzel korábbi feltételezéseinket, miszerint az [ML] $]^{+}$komplex képződése már $\mathrm{pH} 2,5$ alatt befejeződik. $\mathrm{pH}$ 2,5-6 között a rögzített spektrumokon nincs változás, pH 7 felett a komplex jelei fokozatosan alacsonyabb ppm tartomány felé tolódnak el, ami az $\left[\mathrm{MLH}_{-1}\right]$ vegyes hidroxidokomplex képződéséhez köthető. Mivel a deprotonálódás az NMR időskálán gyors cserefolyamat, emiatt a két egyensúlyt tartó komplex átlagjelét látjuk. A jelek eltolódásnak pH-függő változásából az [ML] komplex deprotonálódását jellemző pK-érték számolható.

A fotometriás, $\mathrm{pH}$-potenciometriás, illetve a $\mathrm{pH}$-függő ${ }^{1} \mathrm{H}$ NMR spektrumok változásaiból meghatározott $\left[\mathrm{MLH}_{-1}\right] \lg \beta$, illetve az [ML] komplex pK-értékeit a 10. táblázatban tüntettük fel.

A 33. ábra jól mutatja, hogy pH-metriás mérésekből meghatározott $\left[\mathrm{MLH}_{-1}\right] \lg \beta$-érték alapján az NMR mérésink során alkalmazott koncentrációra számolt eloszlás alapján az [ML] komplex arányának csökkenése jól követi az

$$
[\mathrm{ML}]^{+} \rightleftharpoons\left[\mathrm{MLH}_{-1}\right]+\mathrm{H}^{+}
$$

folyamathoz rendelhető pikolinsav $\mathrm{CH}(5)$ csoportjához tartozó proton jelének eltolódását. 


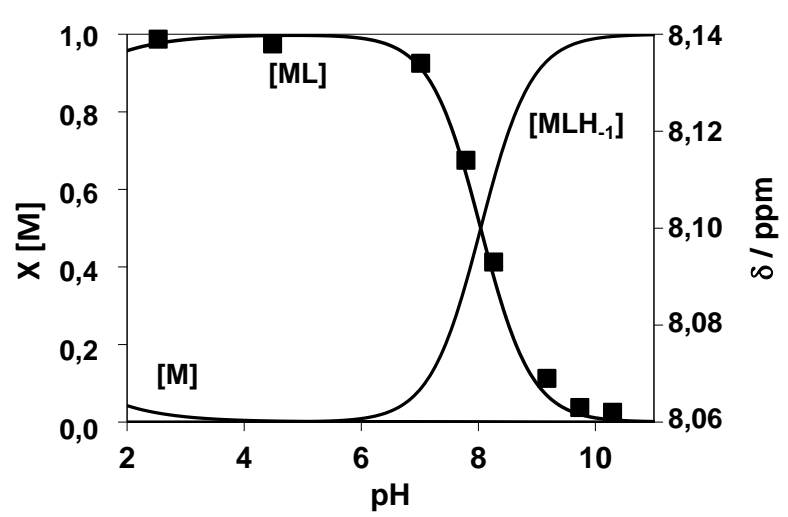

33. ábra: Koncentrációeloszlási görbék a [Ru(II)- $\eta^{6}$-p-cimol]-pikolinsav rendszerben 1:1 fémion-ligandum arány mellett és az ${ }^{1} \mathrm{H}$ NMR spektrumok adatai alapján meghatározott ligandumhoz tartozó $\mathrm{CH}(5)$ csoport jeleinek eltolódásai ( $\bullet$ ).

$$
\left(c_{\mathrm{L}}=\mathrm{c}_{\mathrm{M}}=1 \times 10^{-3} \mathrm{M}, \mathrm{I}=0,2 \mathrm{M} \mathrm{KNO}_{3}, \mathrm{t}=25^{\circ} \mathrm{C}, 10 \% \mathrm{D}_{2} \mathrm{O}\right)
$$

Savas tartományban az $[\mathrm{ML}]^{+}$komplexben feltehetően a $\left[\mathrm{Ru}(\mathrm{II})-\eta^{6}-p\right.$-cimol]-hoz a pikolinsav kétfogú $(\mathrm{O}, \mathrm{N})$ ligandumként koordinálódik öttagú kelátgyürüt kialakítva, ahogy azt a korábban bemutatott XRD-s ábra is mutatja (14. ábra). ${ }^{153} \mathrm{~A}\left[\mathrm{Ru}(\mathrm{II})-\eta^{6}-p\right.$-cimol] szabad, harmadik koordinációs helyén feltehetően vízmolekula van. Az $\left[\mathrm{MLH}_{-1}\right]$ részecske vegyes hidroxidokomplexnek ([ML(OH)]) felel meg, ahol az [ML] részecskében koordinálódott vízmolekula deprotonálódik, és kialakul az $\left[\mathrm{MLH}_{-1}\right]$ komplex.

Bár termodinamikai alapon, a hidrolízist leíró állandók ismeretében várnánk a trihidroxido dimer részecske megjelenését, az ${ }^{1} \mathrm{H}$ NMR mérések azt mutatják, hogy a kialakult [Ru(II)- $\eta^{6}-p$-cimol]-pikolinát komplex bázikus pH-tartományban sem disszociál. Az NMR spektrumokon nagyobb $\mathrm{pH}$ értékeknél ( $\mathrm{pH} 10$ felett) sem jelenik meg a disszociált szabad ligandum, illetve a $\left[\mathrm{M}_{2} \mathrm{H}_{-3}\right]$ részecske jele. Disszociáció jelét az 1 nap után felvett pH 7,4 és 9,0 oldatok NMR spektrumain sem észleljük (34. ábra). Az [ML] komplex lassú disszociációjának feltehetően kinetikai oka van. A

$$
2[\mathrm{ML}]^{+} \rightleftharpoons\left[\mathrm{M}_{2} \mathrm{H}_{-3}\right]^{+}+3 \mathrm{H}^{+}+2 \mathrm{~L}^{-},
$$

illetve az

$$
2\left[\mathrm{MLH}_{-1}\right] \rightleftharpoons\left[\mathrm{M}_{2} \mathrm{H}_{-3}\right]^{+}+\mathrm{H}^{+}+2 \mathrm{~L}^{-}
$$

folyamatok lassúak, kinetikailag gátoltak. Hasonlóan lassú disszociációs folyamatokat tapasztaltak hidroxi-piridinon komplexek esetében is. ${ }^{197}$ 


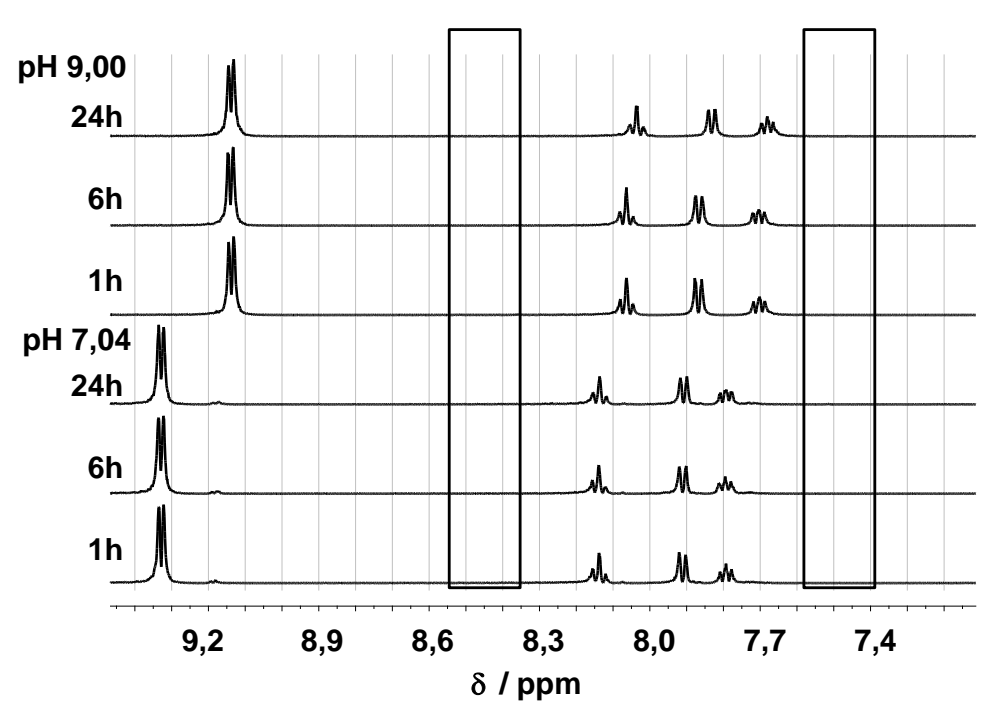

34. ábra: $\left[\mathrm{Ru}(\mathrm{II})-\eta^{6}\right.$-p-cimol]-pikolinsav 1:1 arányú rendszer $\mathrm{pH}$ 7,04 és pH 9,00-n felvett

${ }^{1}$ H NMR spektrumai 1, 6 és 24 h óra múlva a ligandum aromás protonjaihoz tartozó jelek kémiai eltolódásának tartományában.

A bekeretezett spektrumrészletek jelzik, hol várnánk a szabad ligandum jeleinek helyét a spektrumon. $\left(c_{\mathrm{L}}=\mathrm{c}_{\mathrm{M}}=1 \times 10^{-3} \mathrm{M}, \mathrm{I}=0,2 \mathrm{M} \mathrm{KNO}_{3}, \mathrm{t}=25^{\circ} \mathrm{C}, 10 \% \mathrm{D}_{2} \mathrm{O}\right)$

\subsubsection{2. $\left[\operatorname{Ru}(I I)-\eta^{6}\right.$-p-cimol] komplexképződési folyamatai pikolinsav, 6-metil-piko-}

\section{linsav és 2,6-dipikolinsav ligandumokkal kloridionos közegben}

A kloridion versengő ligandumként képes kis mértékben visszaszorítani a pik [Ru(II)$\eta^{6}$-p-cimol]-hoz való koordinációját, a komplexképződés pH 2-nél még így is jelentős. (A koordinált vízmolekula részben kloridra van cserélve, emiatt ebben a közegben meghatározott állandók látszólagos állandóknak tekinthetők, 0,2 M kloridkoncentráció mellett.) A pik komplex nagy stabilitása miatt az [ML] komplex stabilitási állandóját a kloridmentes közeghez hasonlóan fotometriás mérésekkel határoztuk meg pH 2 alatti egyedi minták összeállításával, illetve pH 2 feletti titrálás kombinációjával. 230-538 nm hullámhossz tartományban mért pH-függö spektrumok változásait követve számoltuk [ML] és $\left[\mathrm{MLH}_{-1}\right]$ komplexek stabilitási szorzatait. A fotometriás módszerrel meghatározott [ML] állandót $(\lg \beta[\mathrm{ML}]=8,14)$ rögzítve értékeltük ki a pH-potenciometriás titrálási görbéket, és határoztuk meg az $\left[\mathrm{MLH}_{-1}\right]$ stabilitási szorzatát.

Az állandók közvetlen összevetéséböl is látni lehet, hogy a nitrátos közegben az [ML] stabilitási állandója illetve a pK [ML] értéke is nagyobb. A kloridion ugyanis versengő ligandumként képes részben visszaszorítani a komplexképződést, illetve a komplex hidrolízisét is.

A pH-függő ${ }^{1} \mathrm{H}$ NMR spektrumokat lúgos tartományban vizsgálva információt tudtunk nyerni a komplex hidrolízisével, illetve disszociációjával kapcsolatban is, és megállapítottuk, hogy a spektrumokon még pH 11-nél sem látjuk a disszociáció jelét, nem 
jelenik meg a $\left[\mathrm{M}_{2} \mathrm{H}_{-3}\right]-$ ra jellemző csúcs, melynek helye az ábrán a szaggatott vonallal jelölt részeken lenne várható (35. ábra).

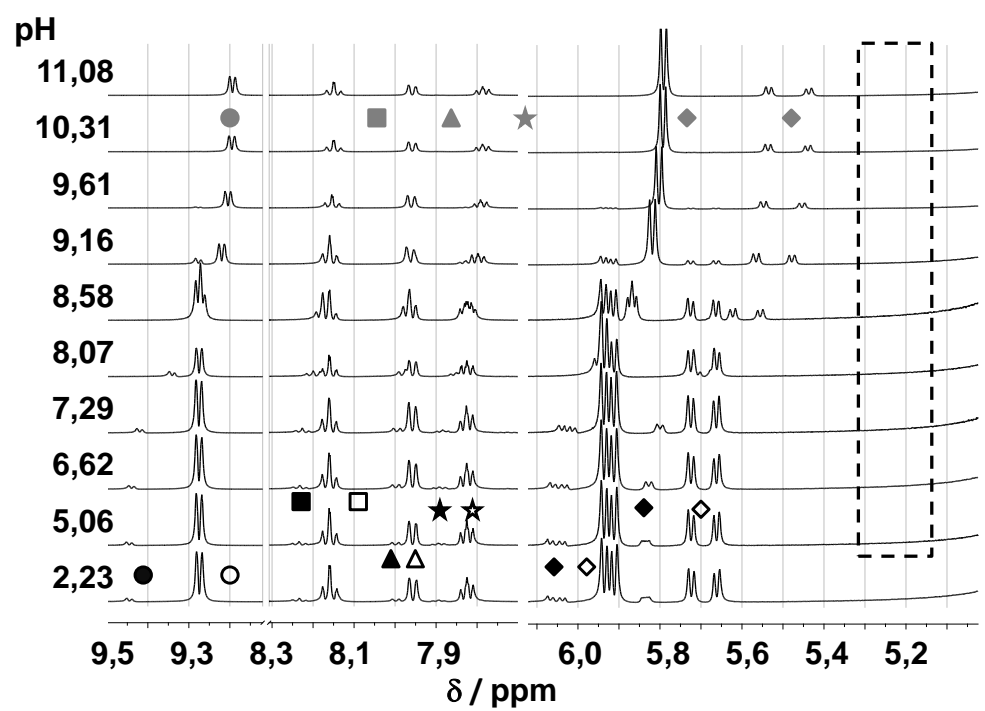

35. ábra: $\left[\mathrm{Ru}(\mathrm{II})-\eta^{6}-p\right.$-cimol]-pikolinsav $1: 1$ arányú rendszer $\mathrm{pH}$ függő ${ }^{1} \mathrm{H}$ NMR spektrumai a ligandum és a

$\left[\mathrm{Ru}(\mathrm{II})-\eta^{6}-p\right.$-cimol] aromás protonjaihoz tartozó jelek kémiai eltolódásának tartományában.

A szaggatott vonallal keretezett spektrumrészletek jelzik a $\left[\mathrm{M}_{2} \mathrm{H}_{3}\right]$ cimol részének aromás protonjainak eltolódásainak helyét, amely nem jelenik meg a titrálás során.

$\operatorname{Lig} \mathrm{CH}(6): \bullet\left[\mathrm{ML}\left(\mathrm{H}_{2} \mathrm{O}\right)\right]^{+} ; \circ[\mathrm{MLCl}] ; \bullet\left[\mathrm{MLH}_{-1}\right]$;

$\operatorname{Lig~} \mathrm{CH}(5):-\left[\mathrm{ML}\left(\mathrm{H}_{2} \mathrm{O}\right)\right]^{+} ; \square[\mathrm{MLCl}] ; \square\left[\mathrm{MLH}_{-1}\right]$;

$\operatorname{Lig} \mathrm{CH}(3): \boldsymbol{\Delta}\left[\mathrm{ML}\left(\mathrm{H}_{2} \mathrm{O}\right)\right]^{+} ; \Delta[\mathrm{MLCl}] ; \Delta\left[\mathrm{MLH}_{-1}\right] ;$

Lig $\mathrm{CH}(4)$ : fekete csillag [ML( $\left.\left.\mathrm{H}_{2} \mathrm{O}\right)\right]^{+}$; üres csillag [MLCl]; szürke csillag $\left[\mathrm{MLH}_{-1}\right]$;

$\left[\mathrm{Ru}(\mathrm{II})-\eta^{6}-p\right.$-cimol] $\operatorname{Ar}(\mathrm{CH}): \diamond\left[\mathrm{ML}\left(\mathrm{H}_{2} \mathrm{O}\right)\right]^{+} ; \diamond[\mathrm{MLCl}] ; \diamond\left[\mathrm{Ru}(\mathrm{II})-\eta^{6}-p-\operatorname{cimol}(\mathrm{Z})_{3}\right]\left(\mathrm{Z}^{-} \mathrm{H}_{2} \mathrm{O}\right.$ vagy $\left.\mathrm{Cl}^{-}\right)$. $\left(\mathrm{c}_{\mathrm{L}}=\mathrm{c}_{\mathrm{M}}=1 \times 10^{-3} \mathrm{M}, \mathrm{I}=0,2 \mathrm{M} \mathrm{KCl}, \mathrm{t}=25^{\circ} \mathrm{C}, 10 \% \mathrm{D}_{2} \mathrm{O}\right)$

Az irodalomban találtunk információt arra vonatkozóan, hogy szilárd fázisban igazolták, hogy az aromás gyürüben lévő piridin-N-ek képesek egyfogú koordinációra is (más donoratom jelenlétének hiányában), ${ }^{152}$ így a biszkomplexek képződése elképzelhető lenne a pikolinsav, illetve származékainak esetében is. Annak bizonyítására, hogy a mi rendszereinkben kizárólag monokomplexek képződnek 1:1 illetve 1:2 fémion-ligandum aránynál vizsgáltuk az ${ }^{1} \mathrm{H}$ NMR spektrumok $\mathrm{pH}$ függését. $\mathrm{Az}$ 1:2 fémion-ligandum aránynál felvett spektrumokon a monokomplexek és a nem kötött ligandum jelén kívül nem jelenik meg új csúcs. Csak olyan részecskék jelét látni, melyek az 1:1 aránynál is megjelentek. Ezen kívül pH 3,2 értéknél, változó fémion-ligandum arány mellett vizsgáltuk a felvett ${ }^{1} \mathrm{H}$ NMR spektrumokat (36. ábra). Ezen a pH-n a komplexképződés már 100\%-os, és még nem kezdődnek el deprotonálódási folyamatok. A spektrumok kiértékelése során nem láttuk jelét biszkomplex képződésének, így annak jelenlétét ebben az esetben is kizárhatjuk. 
a.

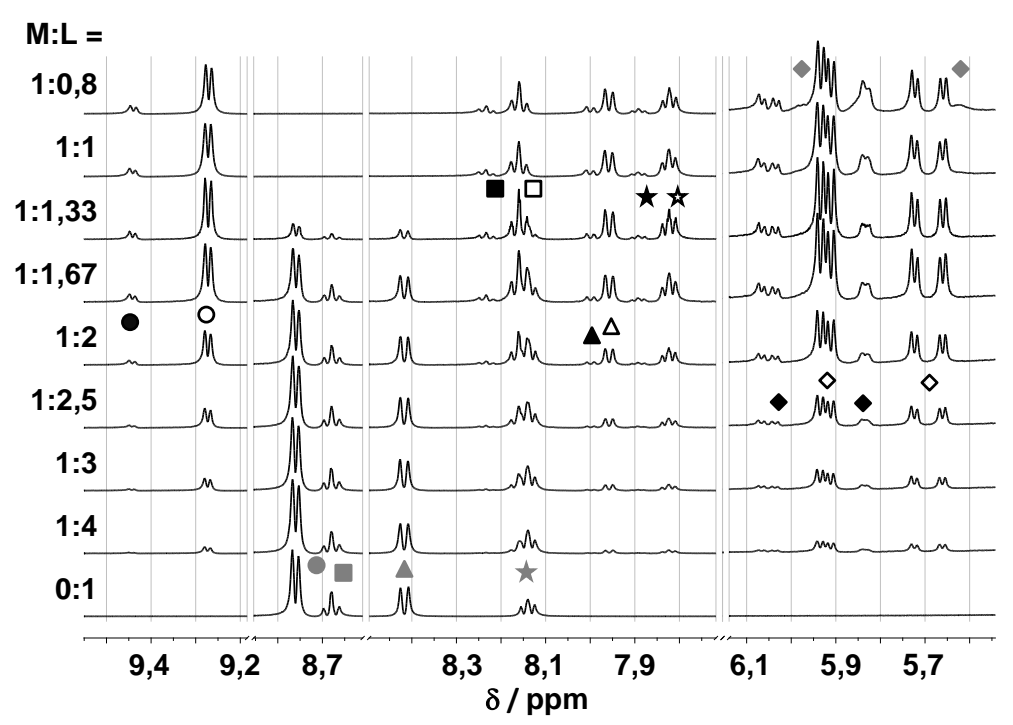

b.

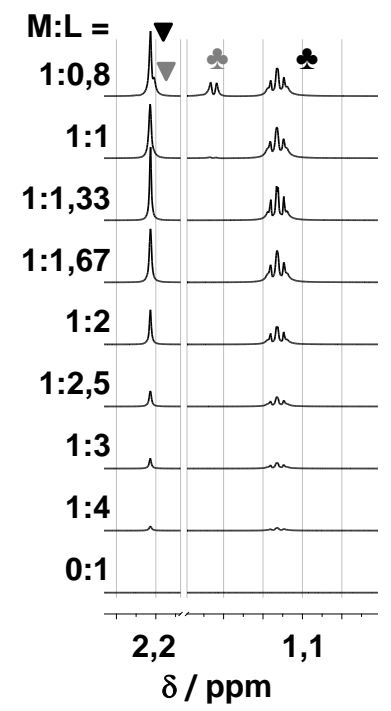

36. ábra: $\left[\mathrm{Ru}(\mathrm{II})-\eta^{6}-p\right.$-cimol]-pikolinsav változó fémion-ligandum arány mellett felvett ${ }^{1} \mathrm{H}$ NMR spektrumainak részletei az aromás (a.) és alifás (b.) régiókban.

$\operatorname{Lig~} \mathrm{CH}(6): \bullet\left[\mathrm{ML}\left(\mathrm{H}_{2} \mathrm{O}\right)\right]^{+} ;$○ [MLCl]; • [HL];

$\operatorname{Lig} \mathrm{CH}(5)$ : $\mathbf{~}\left[\mathrm{ML}\left(\mathrm{H}_{2} \mathrm{O}\right)\right]^{+} ; \square[\mathrm{MLCl}] ; \square[\mathrm{HL}]$;

$\operatorname{Lig} \mathrm{CH}(3): \boldsymbol{\Delta}\left[\mathrm{ML}\left(\mathrm{H}_{2} \mathrm{O}\right)\right]^{+} ; \Delta[\mathrm{MLCl}] ; \Delta[\mathrm{HL}] ;$

Lig $\mathrm{CH}(4)$ : fekete csillag [ML $\left.\left(\mathrm{H}_{2} \mathrm{O}\right)\right]^{+}$; üres csillag [MLCl]; szürke csillag [HL];

$\left[\mathrm{Ru}(\mathrm{II})-\eta^{6}-p\right.$-cimol] $\mathrm{Ar}(\mathrm{CH}):\left[\mathrm{ML}\left(\mathrm{H}_{2} \mathrm{O}\right)\right]^{+} ; \diamond[\mathrm{MLCl}] ; \diamond\left[\mathrm{Ru}(\mathrm{II})-\eta^{6}-p\right.$-cimol$\left.(\mathrm{Z})_{3}\right]$

$\left[\mathrm{Ru}(\mathrm{II})-\eta^{6}-p\right.$-cimol $] \mathrm{Me}\left(\mathrm{CH}_{3}\right): \boldsymbol{\nabla}[\mathrm{ML}] ; \nabla\left[\mathrm{Ru}(\mathrm{II})-\eta^{6}-p-\operatorname{cimol}(\mathrm{Z})_{3}\right]$

$\left[\mathrm{Ru}(\mathrm{II})-\eta^{6}-p\right.$-cimol] iProp $\left(\mathrm{CH}_{3}\right):[\mathrm{ML}] ;\left[\mathrm{Ru}(\mathrm{II})-\eta^{6}-p-\operatorname{cimol}(\mathrm{Z})_{3}\right]$

$\left(\mathrm{pH}=3,2 ; \mathrm{c}_{\mathrm{L}}=2 \times 10^{-3} \mathrm{M} ; \mathrm{I}=0,2 \mathrm{M} \mathrm{KCl}, \mathrm{t}=25^{\circ} \mathrm{C}, 10 \% \mathrm{D}_{2} \mathrm{O}, \mathrm{Z}=\mathrm{H}_{2} \mathrm{O}\right.$ vagy $\left.\mathrm{Cl}^{-}\right)$

A kloridion jelenlétében a felvett ${ }^{1} \mathrm{H}$ NMR spektrumokon még egy fontos jelenségre figyelhetünk fel. Az [ML] komplex képződési tartományában a spektrumokon az [ML] komplex jeleinek egy nagyobb, illetve egy kisebb intenzitású párja is azonosítható, melyeket a spektrumokon teli, illetve üres jelzésekkel különböztettünk meg. Megállapítottuk, hogy a kisebb intenzitású jelek az akva-, míg a nagyobb intenzitásúak a kloridokomplexhez tartoznak. Az NMR időskálához képest lassú cserefolyamatok miatt a két komplex jelét külön látjuk. A klorido-akva ligandum cserét az [ML] komplexben részletesen vizsgáltuk. $\mathrm{pH}$ 3,2-nél vettünk fel ${ }^{1} \mathrm{H}$ NMR spektrumokat 1:1 fém:ligandum arány mellett a kloridion koncentrációját változtatva (37. ábra). Egyrészt, ez a mérési sorozat segítette a spektrumokon a klorido- és akvakomplex jeleinek azonosítását, másrészt egyensúlyi állandót $\left(\lg \mathrm{K}^{*}\right)$ tudtunk becsülni a

$$
\left[\mathrm{ML}\left(\mathrm{H}_{2} \mathrm{O}\right)\right]^{+}+\mathrm{Cl}^{-} \rightleftharpoons[\mathrm{MLCl}]+\mathrm{H}_{2} \mathrm{O}
$$

folyamatra. A csúcs alatti területek arányaiból tudtuk számolni az akva- illetve kloridokomplexek koncentrációjának arányát, majd ez alapján becsültük $\lg \mathrm{K}^{*}$ állandó értékét, aminek segítségével a különböző kloridion koncentrációk mellett megjósolható az [ML] akva-klorido részecskék aránya. 


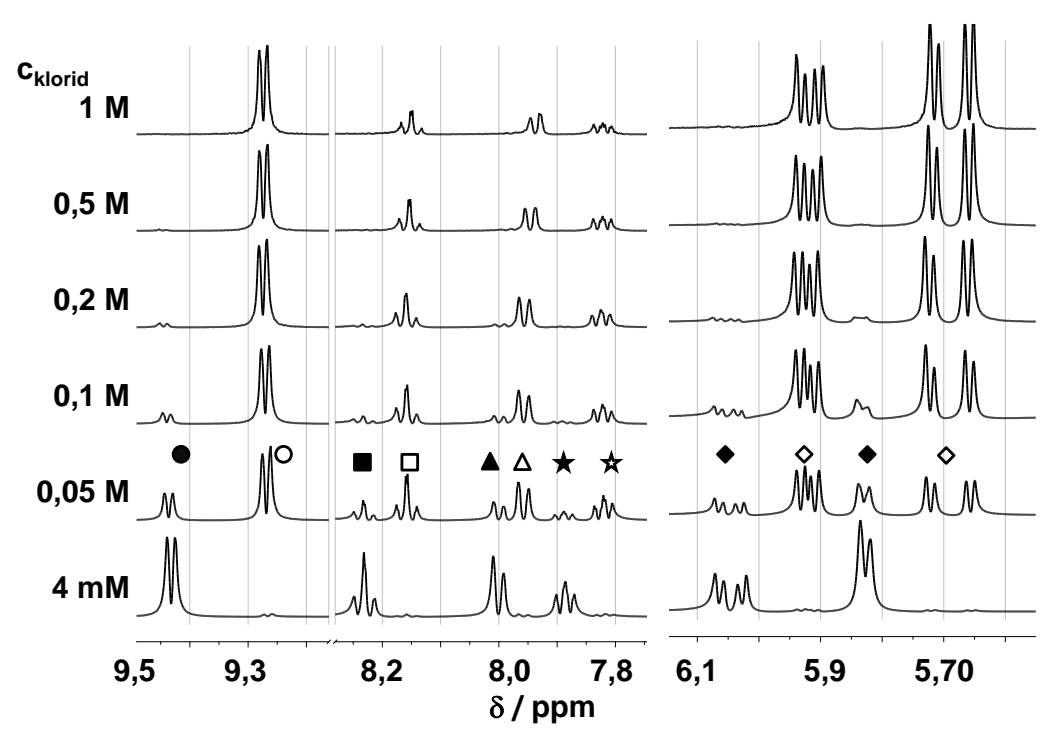

37. ábra: $\left[\mathrm{Ru}(\mathrm{II})-\eta^{6}-p\right.$-cimol]-pikolinsav 1:1 fémion-ligandum aránynál felvett ${ }^{1} \mathrm{H}$ NMR spektrumainak részletei változó kloridion koncentráció mellett.

$\operatorname{Lig~} \mathrm{CH}(6): \bullet\left[\mathrm{ML}\left(\mathrm{H}_{2} \mathrm{O}\right)\right]^{+} ;$; $[\mathrm{MLCl}]$;

Lig $\mathrm{CH}(5):$ - $\left[\mathrm{ML}\left(\mathrm{H}_{2} \mathrm{O}\right)\right]^{+} ; \square[\mathrm{MLCl}]$;

$\operatorname{Lig~} \mathrm{CH}(3): \boldsymbol{\Delta}\left[\mathrm{ML}\left(\mathrm{H}_{2} \mathrm{O}\right)\right]^{+} ; \Delta[\mathrm{MLCl}] ;$

Lig $\mathrm{CH}(4)$ : fekete csillag $\left[\mathrm{ML}\left(\mathrm{H}_{2} \mathrm{O}\right)\right]^{+}$; üres csillag [MLCl];

$\left[\mathrm{Ru}(\mathrm{II})-\eta^{6}-p\right.$-cimol] $\mathrm{Ar}(\mathrm{CH}):\left[\mathrm{ML}\left(\mathrm{H}_{2} \mathrm{O}\right)\right]^{+} ; \diamond[\mathrm{MLCl}]$

$\left(\mathrm{pH}=3,2 ; \mathrm{c}_{\mathrm{L}}=\mathrm{c}_{\mathrm{M}}=2 \times 10^{-3} \mathrm{M} ; \mathrm{t}=25^{\circ} \mathrm{C}, 10 \% \mathrm{D}_{2} \mathrm{O}\right)$

[Ru(II)- $\eta^{6}-p$-cimol]-6-Mepik rendszer tanulmányozása során a $\left[\mathrm{Ru}(\mathrm{II})-\eta^{6}-p\right.$-cimol]-pik rendszer vizsgálatához hasonló méréseket, kiértékelési módszereket végeztünk. A spektrofotometriás és pH-metriás mérésekből meghatározott állandókat a 10. táblázatban tüntettük fel. A stabilitási szorzatokat közvetlenül összehasonlítva megállapítható, hogy a 6-Mepik ligandum [Ru(II)- $\eta^{6}-p$-cimol $]$ komplexei kisebb stabilitásúak a [Ru(II)- $\eta^{6}-p$-cimol]pikolinát komplexekhez képest.

Ezt támasztják alá a bázicitással korrigált stabilitás állandó értékei is (lg K' = 3,00 (pik); $\lg \mathrm{K}^{\prime}=1,58$ (6-Mepik)) melyet feltehetően a piridin-gyürün lévő metilcsoport szférikus gátlása okozhat. Hasonló tendenciát figyeltek meg cink(II) és vanadil(IV)ionok komplexei esetén is, ott a pikolinsav kompakt méretével magyarázták a nagyobb stabilitást a 6-Mepikhez képest. ${ }^{198}$ Feltehetően a kisebb stabilitás az oka annak, hogy [Ru(II)- $\eta^{6}-p$-cimol] 6metil-pikolinsavval alkotott komplex pH 10 felett disszociál, és megjelenik a rendszerben a szabad ligandum, illetve a kétmagvú $\left[\mathrm{M}_{2} \mathrm{H}_{-3}\right]$ részecske, melynek jelei az ${ }^{1} \mathrm{H} \mathrm{NMR}$ spektrumokon is jól beazonosíthatók (38. ábra). 
a.

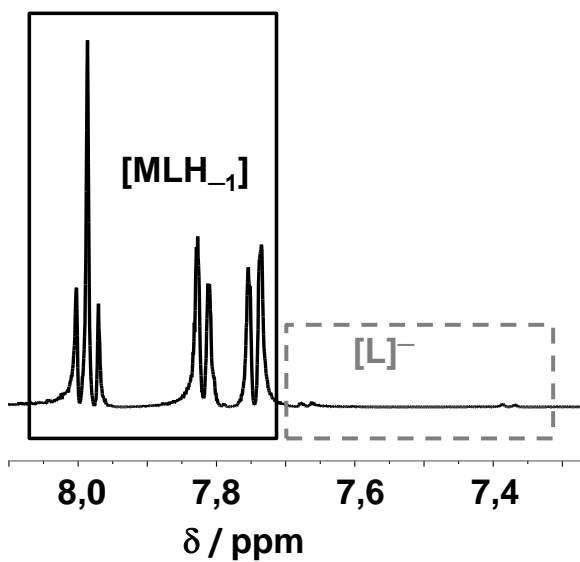

b.

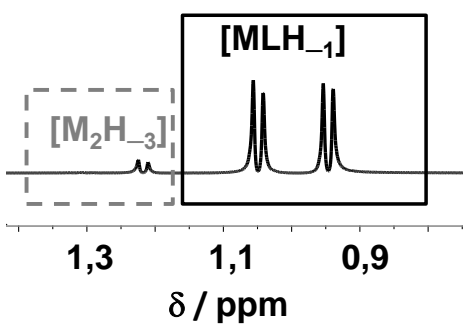

38. ábra: $\left[\mathrm{Ru}(\mathrm{II})-\eta^{6}\right.$ - $p$-cimol]-6-metil-pikolinsav rendszer ${ }^{1} \mathrm{H}$ NMR spektruma lúgos közegben (pH 10,58), a ligandum aromás (a.) és a $\left[\mathrm{Ru}(\mathrm{II})-\eta^{6}-p\right.$-cimol] $\operatorname{Prop}\left(\mathrm{CH}_{3}\right)$ protonjaihoz (b.) tartozó jelek kémiai eltolódásának tartományában.

A szaggatott vonallal bekeretezett rész jelzi a szabad ligandum illetve $\left[\mathrm{M}_{2} \mathrm{H}_{-3}\right]$ megjelenését. $\left(\mathrm{c}_{\mathrm{L}}=\mathrm{c}_{\mathrm{M}}=2 \times 10^{-3} \mathrm{M}, \mathrm{I}=0,2 \mathrm{M} \mathrm{KCl}, \mathrm{t}=25^{\circ} \mathrm{C}, 10 \% \mathrm{D}_{2} \mathrm{O}\right)$

Mivel a disszociáció lassú folyamat, és a vizsgálat ideje alatt az egyensúly nem áll be a rendszerben, ezért méréseinket csak $\mathrm{pH}$ 10-ig, a kétmagvú részecske megjelenéséig vettük figyelembe a kiértékelések során.

A meghatározott stabilitási szorzatok segítségével számolt koncentrációeloszlási görbéket a pik-[Ru(II)- $\eta^{6}-p$-cimol], illetve a 6-Mepik-[Ru(II)- $\eta^{6}-p$-cimol] rendszerre a 39. ábra mutatja be.

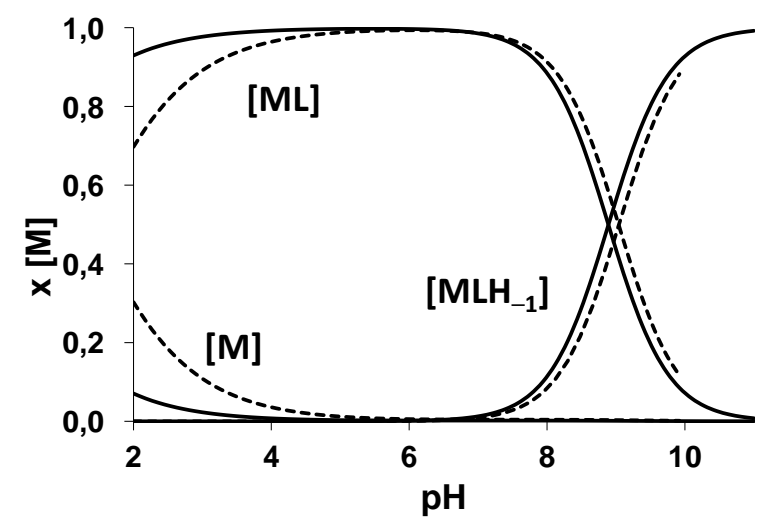

39. ábra: [Ru(II)- $\eta^{6}-p$-cimol]-pik (folyamatos vonalak) és [Ru(II)- $\eta^{6}-p$-cimol]-6-Mepik (szaggatott vonalak) rendszerek koncentrációeloszlási görbéi $\left(c_{L}=c_{M}=2 \times 10^{-3} \mathrm{M}, \mathrm{I}=0,2 \mathrm{M} \mathrm{KCl}, \mathrm{t}=25^{\circ} \mathrm{C}\right)$

[Ru(II)- $\eta^{6}-p$-cimol] 2,6-dipikolinsavval való komplexképződése során savas közegben második karboxilcsoport jelenléte miatt lehetőség van [MLH] komplex képződésére is mely során a nem koordinálódó karboxilcsoport protonált formában van jelen a komplexben. A komplexképződés az pikolinsav és 6-metil-pikolinsavhoz hasonlóan, ebben az esetben is nagyon savas pH-n indul. A 40. ábrán bemutatott titrálási görbéken pH 2-nél 
már nincs szabad $\left[\mathrm{Ru}(\mathrm{II})-\eta^{6}-p\right.$-cimol] a rendszerben, és [MLH] komplex deprotonálódása is szinte teljesnek mondható.

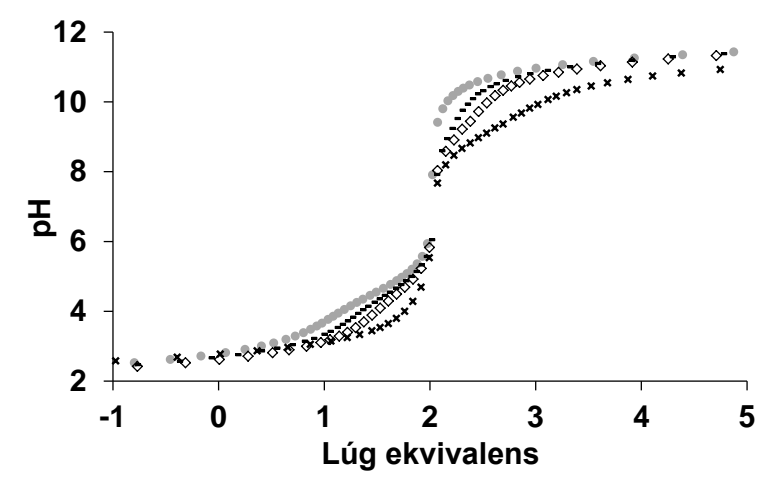

40. ábra: $\left[\mathrm{Ru}(\mathrm{II})-\eta^{6}-p\right.$-cimol]-2,6-dipikolinsav titrálási görbéi (×) $1: 1 ;(\diamond) 1: 2 ;(-) 1: 4 ;(\bullet)$ 0:1 fémion-ligandum arány mellett $\left(c_{L}=2 \times 10^{-3} \mathrm{M}, \mathrm{I}=0,2 \mathrm{M} \mathrm{KCl}, \mathrm{t}=25^{\circ} \mathrm{C}\right)$

Ezért pH-potenciometria önmagában ennél a rendszernél sem alkalmas a komplexképződés teljes elemzésére. [MLH] és [ML] komplexek stabilitását pH 1-2 közötti egyedi minták UV-látható abszorbancia spektrumai alapján határoztuk meg $\lambda=224-540 \mathrm{~nm}$ között (41. ábra).

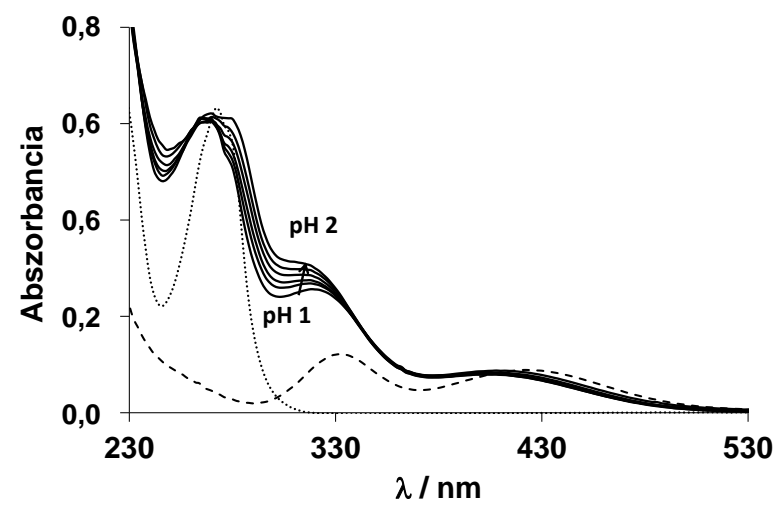

41. ábra: $\left[\mathrm{Ru}(\mathrm{II})-\eta^{6}-p\right.$-cimol]-2,6-dipikolinsav rendszer $\mathrm{pH}$-függő UV-látható spektrumai pH 1 - 2 tartományban (folytonos vonalak), illetve összehasonlításként a ligandum (pontozott spektrum) és a [Ru(II)- $\eta^{6}-p$-cimol] (szaggatott vonal) spektruma $\mathrm{pH} 2$-nél. $\left(\mathrm{c}_{\mathrm{L}}=\mathrm{c}_{\mathrm{M}}=1,2 \times 10^{-4} \mathrm{M}, \mathrm{I}=0,2 \mathrm{M} \mathrm{KCl} / \mathrm{HCl}, \mathrm{t}=25^{\circ} \mathrm{C}\right)$

A kiértékelés során a vizsgált pH-tartományban figyelembe vettük a ligandum spektrumainak változásait is $\mathrm{pH} \mathrm{1-2} \mathrm{tartományban.} \mathrm{A} \mathrm{41.} \mathrm{ábrán} \mathrm{bemutatott} \mathrm{pH} 2$ alatti minták spektrumaiból jól látszik, hogy $\lambda=320-380 \mathrm{~nm}$ tartományban (ahol a ligandumnak nincs elnyelése) az 1:1 arányú minták esetében már a legsavasabb kémhatású minta abszorbanciája is jóval nagyobb, mint a szabad $\left[\mathrm{Ru}(\mathrm{II})-\eta^{6}-p\right.$-cimol] saját spektruma azonos koncentráció mellet, ami jelzi, hogy már pH 1-nél is jelentős a komplexképződés.

A pH 1-2 között rögzített spektrumok változásai alapján számoltuk [MLH] és [ML] részecskék stabilitási szorzatait, majd ezeket állandó értéken rögzítve értékeltük ki $\mathrm{pH} 2$ 
11 tartományban a minták titrálás során mért abszorbancia spektrumait és a pHpotenciometriás görbék lúgos szakaszát. A 40. ábrán bemutatott titrálási görbéken jól látható, hogy $\mathrm{pH} \sim 8$ felett egy protontermelő folyamat indul el, melyet $\left[\mathrm{MLH}_{-1}\right]$ komplex képződéséhez rendelhetünk. Emellett az 1:1 fémion-ligandum arányú titrálás erősen lúgos szakaszában a $\left[\mathrm{M}_{2} \mathrm{H}_{3}\right]$ részecske képződése is lúgfogyasztó folyamat. Ligandum felesleg esetében a komplex disszociációját kísérő lúgfogyasztó folyamatot nem észleltük, a ligandum nagyobb koncentrációja valószínűleg megvédi a komplexet a disszociációtól.

A fentebb leírt folyamatokat az ${ }^{1} \mathrm{H}$ NMR méréseink megerősítették. A 1:1 és 1:2 fémion-ligandum arányú rendszerekben követtük a komplexképződést változó $\mathrm{pH}-\mathrm{n}$ a spektrumok változásai alapján. A reprezentatív mérési spektrumsorozatot 1:1 fémionligandum arány mellett a 42. ábra mutatja be.

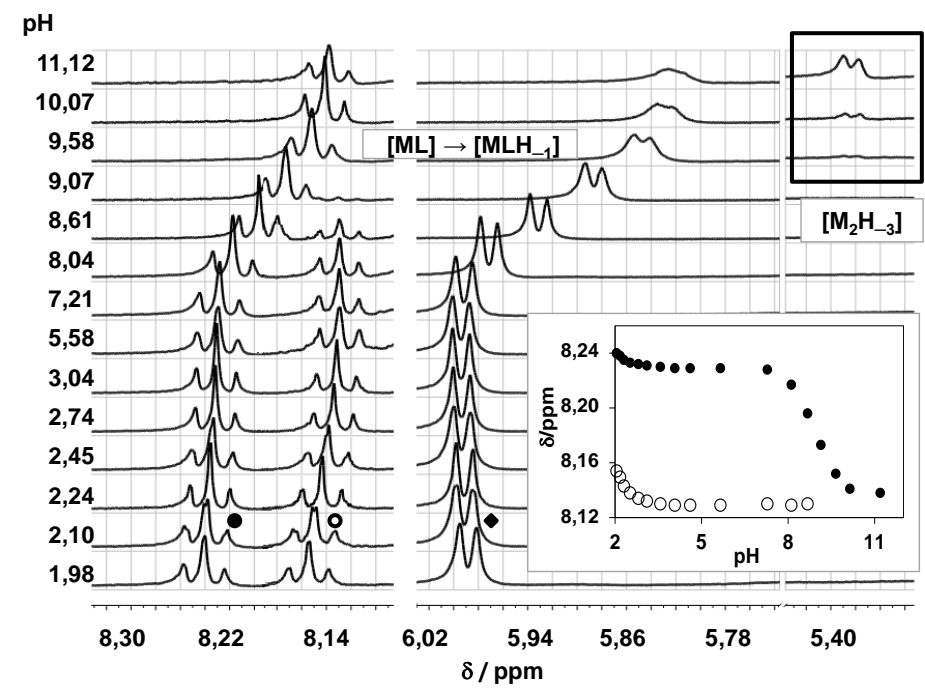

42. ábra: $\left[\mathrm{Ru}(\mathrm{II})-\eta^{6}-p\right.$-cimol]-2,6-dipikolinsav $1: 1$ arányú rendszer $\mathrm{pH}$ függő ${ }^{1} \mathrm{H}$ NMR spektrumai a ligandum és $\left[\mathrm{Ru}(\mathrm{II})-\eta^{6}-p\right.$-cimol] aromás protonjaihoz tartozó jelek kémiai eltolódásnak tartományában. $\operatorname{Lig~} \mathrm{CH}(4): \bullet\left[\mathrm{ML}\left(\mathrm{H}_{2} \mathrm{O}\right)\right] ;$ ○ $[\mathrm{MLCl}]^{-}$;

$\left[\mathrm{Ru}(\mathrm{II})-\eta^{6}-p\right.$-cimol] $\mathrm{Ar}(\mathrm{CH}): \bullet[\mathrm{MLX}] ;\left(\mathrm{X}=\mathrm{H}_{2} \mathrm{O}\right.$ vagy $\left.\mathrm{Cl}^{-}\right)$

A beszúrt diagram az ${ }^{1} H$ NMR spektrumok adatai alapján meghatározott komplexben lévö ligandumhoz tartozó CH(4) csoport protonok jeleinek eltolódásait mutatja a pH függvényében.

$\left(\mathrm{c}_{\mathrm{L}}=\mathrm{c}_{\mathrm{M}}=2 \times 10^{-3} \mathrm{M}, \mathrm{I}=0,2 \mathrm{M} \mathrm{KCl}, \mathrm{t}=25^{\circ} \mathrm{C}, 10 \% \mathrm{D}_{2} \mathrm{O}\right)$

A spektrumokon pH 2-nél nem jelenik meg a szabad ligandumhoz, illetve $\left[\mathrm{Ru}(\mathrm{II})-\eta^{6}-p-\right.$ cimol]-hoz tartozó jelcsoport. Hogy az

$$
[\mathrm{MLHX}]^{\mathrm{n}} \rightleftharpoons[\mathrm{MLX}]^{\mathrm{n}-1}+\mathrm{H}^{+}
$$$$
\left(\mathrm{X}=\mathrm{H}_{2} \mathrm{O} \text { vagy } \mathrm{Cl}^{-}\right)
$$

folyamatot részletesebben is tanulmányozni tudjuk pH 2-3 között a spektrumokat sürübben rögzítettük. A feltételezett deprotonálódási folyamatot bizonyítja, hogy a részletesebben vizsgált savas tartományban a ligandumhoz tartozó protonok jelei $\mathrm{pH}$ 2,7-ig kismértékü diamágneses eltolódást mutatnak (42. ábra, beszúrt diagram). 
A pik és 6-Mepik ligandumokkal való komplexképződéshez hasonlóan a lassú cserefolyamat miatt, az klorido- és akvakomplex jelei a dipikolinsav esetében is külön jelet adnak a spektrumokon. pH 8 felett megindul az [ML] komplex hidrolízise. Az [MLCl] $]^{-}$ komplexhez rendelhető jelek intenzitása csökken, ami jelzi a komplex arányának csökkenését, az $\left[\mathrm{ML}\left(\mathrm{H}_{2} \mathrm{O}\right)\right]$ jelei pedig a koordinált vízmolekula deprotonálódása miatt alacsonyabb ppm értékek felé tolódnak el. pH 9 felett az 1:1 fémion-ligandum arányú rendszerben megjelenik a szabad ligandumhoz, illetve a $\left[\mathrm{M}_{2} \mathrm{H}_{-3}\right]-$ hoz rendelhető protonok jele. A 1:2 fémion-ligandum arányú rendszerekben a szabad fémionnak nem észlelhető jele, mert a ligandum felesleg, ahogy azt a pH-potenciometriás titrálási görbék alapján feltételeztük, képes megvédeni a komplexet a disszociációtól.

A számolt stabilitási szorzatok, illetve a bázicitással korrigált $\lg \mathrm{K}$ ' állandó is azt mutatja, hogy a 2,6-dipikolinsav nagyobb stabilitású komplexet képez a $\left[R u(I I)-\eta^{6}-p\right.$ cimol]-lal, mint a pik, illetve annak 6-metil származéka. Az egyszeresen negatív töltésü pikolinát ligandumokhoz képest a kétszeresen negatív töltésü dipikolinát koordinálódása kedvezőbb lehet a kétszeresen pozitív töltésü [Ru(II)- $\eta^{6}-p$-cimol]-hoz.

Habár a 2,6-dipikolinsav háromfogú ligandumként is viselkedhet pl. Zn(II), ${ }^{199} \mathrm{Cu}(\mathrm{II}),{ }^{200}$ $\mathrm{V}(\mathrm{IV}) \mathrm{O}^{2+},{ }^{201} \mathrm{~V}(\mathrm{~V}) \mathrm{O}_{2}{ }^{+}{ }^{201} \mathrm{Ru}(\mathrm{II})$ vagy $\mathrm{Ru}(\mathrm{III}){ }^{2}{ }^{2}{ }^{202,203,204,205}$ esetén, úgy gondoljuk, sztérikus okok miatt csak két donoratomján $\left(\mathrm{COO}^{-}, \mathrm{N}\right)$ keresztül koordinálódik a központi fémionhoz.

A második karboxilcsoport jelenléte amellett, hogy töltéssemlegesítés révén növeli az [ML] komplex stabilitását, hatással van a klorido-akva egyensúlyra is. Az [ML] komplex töltésviszonya a ligandumon lévő második deprotonálódott karboxilcsoport miatt az előző rendszerekhez képest eltérést mutat. $\left[\mathrm{Ru}(\mathrm{II})-\eta^{6}-p\right.$-cimol]-dipik rendszerben az akvakomplexnek semleges, a kloridokomplexnek pedig negatív töltése van. Úgy gondoljuk, a deprotonálódott, negatív töltésű karboxilátcsoport képes visszaszorítani a szintén negatív töltésü kloridion koordinálódását a harmadik szabad koordinációs helyen. Feltételezésünknek nem mond ellent a változó kloridkoncentráció mellett 1:1 fémionligandum arány mellett rögzített ${ }^{1} \mathrm{H}$ NMR spektrumsorozat sem (43. ábra, a, b). Az ábrákon első látásra is jól látható, hogy 0,2 M kloridkoncentrációnál 50-50 \%-ban van jelen a kétféle $[\mathrm{ML}]$ komplex. A két komplex aránya az $\left[\mathrm{ML}\left(\mathrm{H}_{2} \mathrm{O}\right)\right]+\mathrm{Cl}^{-} \rightleftharpoons[\mathrm{MLCl}]^{-}+$ $\mathrm{H}_{2} \mathrm{O}$ folyamatra becsült állandó alapján számolt koncentrációeloszlás görbéről is leolvasható. Az akva/klorido cserét jellemző $\lg \mathrm{K}^{*}$ állandót az egyes részecskékhez tartozó jelek integráljai alapján számolt akva- és kloridokomplexek egymáshoz viszonyított aránya alapján becsültük meg. 
a.

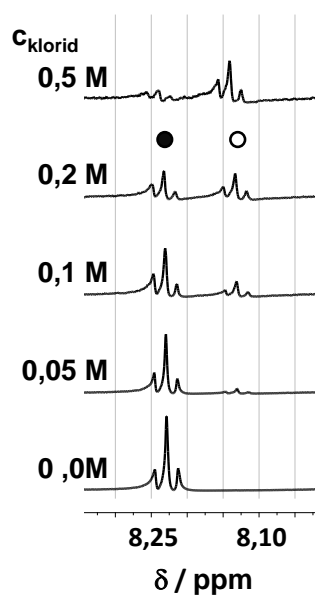

b.

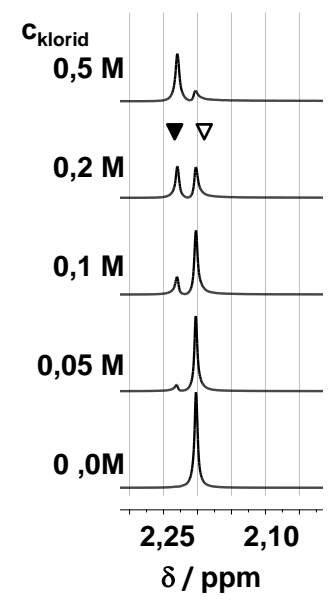

43. ábra: $\left[\mathrm{Ru}(\mathrm{II})-\eta^{6}-p\right.$-cimol]-2,6-dipikolinsav 1:1 fémion-ligandum aránynál felvett ${ }^{1} \mathrm{H}$ NMR spektrumainak részletei változó kloridion koncentráció mellett (a) aromás és (b) alifás régióban Lig $\mathrm{CH}(4): \bullet\left[\mathrm{ML}\left(\mathrm{H}_{2} \mathrm{O}\right)\right]^{+} ; \circ[\mathrm{MLCl}] ;$

$\left[\mathrm{Ru}(\mathrm{II})-\eta^{6}-p\right.$-cimol] $\mathrm{Me}\left(\mathrm{CH}_{3}\right): \boldsymbol{\nabla}\left[\mathrm{ML}\left(\mathrm{H}_{2} \mathrm{O}\right)\right]^{+} ; \nabla[\mathrm{MLCl}] ;$ $\left(\mathrm{c}_{\mathrm{L}}=\mathrm{c}_{\mathrm{M}}=2 \times 10^{-3} \mathrm{M}, \mathrm{t}=25^{\circ} \mathrm{C}, 10 \% \mathrm{D}_{2} \mathrm{O}\right)$

$\mathrm{Az}[\mathrm{ML}]$ komplex nagy stabilitása ellenére valószínüleg a pikolinát komplexekhez képest nagyobb akvakomplex arány (44. ábra) és a kloridokomplexek negatív töltése az oka annak, hogy a 2,6-dipikolinsav [Ru(II)- $\eta^{6}-p$-cimol] komplexe nem mutat különösebb rákellenes aktivitást. A pikolinsav semleges töltésü kloridokomplexei valószínüleg könnyebben át tudnak jutni a rákos sejtek membránjain. A vérhez képest a sejtplazmában a kloridkoncentráció kisebb, és a sejt belsejében a klorid ligandum vízmolekulára cserélődik, ami valószínűleg egy fontos aktivációs lépés lehet a komplexek hatásmechanizmusában. A dipikolinsav $\left[\mathrm{ML}\left(\mathrm{H}_{2} \mathrm{O}\right)\right]$ komplexében, amely valószínűleg már a szérumban domináns részecske az könnyen távozó vízmolekulát a vérszérum kis és esetleg nagy molekulatömegü komponensei már a vérben könnyen kiszorítják, így elképzelhető, hogy a komplex be sem tud jutni a rákos sejtekbe. 


\subsubsection{1. $\left[\operatorname{Ru}(\mathrm{II})-\eta^{6}-p\right.$-cimol]-tioallomaltol rendszer tanulmányozása kloridiont tar-}

talmazó közegben

A [Ru(II)- $\eta^{6}-p$-cimol] komplexképződés folyamatáról tioallomaltol ligandummal $\mathrm{pH}$ potenciometriás, UV-látható fotometriás és ${ }^{1} \mathrm{H}$ NMR spektroszkópiás mérésekkel nyertünk információkat 0,2 M kloridion jelenlétében. A hidroxi-tiopir(idin)on típusú vegyületekre jellemző, hogy könnyen oxidálódnak, ezért méréseinkhez igyekeztünk oxigénmentes körülményeket biztosítani.

Az 1:1 fémion-ligandum arányú rendszerek pH-potenciometriás titrálási görbéi azt mutatják, hogy a ligandum teljes proton kiszorítást szenved már a titrálás kiinduló pontján, pH 2-nél, azaz a komplexképződés már ilyen kis pH-n is teljesnek mondható. Ezért a monokomplex stabilitási állandójának meghatározása pH-potenciometriás mérésekkel nem volt lehetséges. $\mathrm{pH} \sim 6$ felett a titrálás során lassú, nem egyensúlyi, protontermelő folyamat indul el, amely végül csapadék megjelenéséhez vezet az oldatban. A rendszerben történő folyamatok vizsgálatát UV-látható spektrofotometriás titrálásokkal is kiegészítettük $\mathrm{pH} 2$ 11,5 tartományban; a rendszer $\mathrm{KCl}$ tartalmát $\mathrm{HCl}$-ra cserélve (így megtartva a 0,2 $\mathrm{M}$ ionerősséget) pH 0,8-2 között rögzítettük az egyedi minták abszorbancia spektrumait.

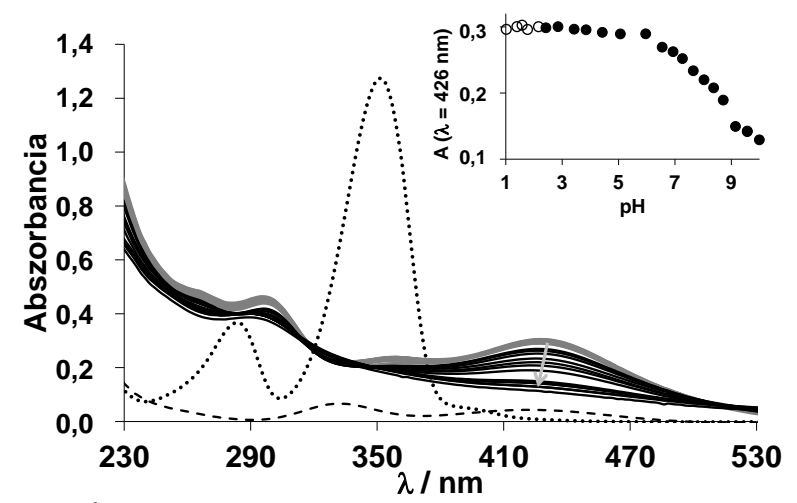

45. ábra: $\mathrm{A}\left[\mathrm{Ru}(\mathrm{II})-\eta^{6}-p\right.$-cimol]-tioallomaltol rendszer $\mathrm{pH}$-függő UV-látható spektrumai.

A szürkével jelölt görbék a pH 0,8 - 2 tartományban felvett egyedi minták spektrumai, a fekete görbék a titrálás folyamán pH 2 - 11 között felvett minták hígítással korrigált abszorbancia spektrumai (a pH a szürke nyíl irányában nő).

Összehasonlításként ábrázoltuk a ligandum (pontozott spektrum) és a [Ru(II)- $\eta^{6}-p$-cimol] (szaggatott vonal) $\mathrm{pH}$ 2,1-nél rögzített spektrumait.

A beszúrt diagram az abszorbancia változását mutatja a pH-függvényében $(\lambda=426 \mathrm{~nm})$. $\left(\mathrm{c}_{\mathrm{L}}=\mathrm{c}_{\mathrm{M}}=3,2 \times 10^{-4} \mathrm{M}, \mathrm{I}=0,2 \mathrm{M} \mathrm{KCl} / \mathrm{HCl} ; \mathrm{t}=25^{\circ} \mathrm{C}\right)$

A 45. ábran látható, hogy $\mathrm{pH} \mathrm{0,8-6}$ között rögzített spektrumok jelentősen különböznek a szabad ligandum, illetve [Ru(II)- $\eta^{6}-p$-cimol] spektrumától, azonban egymáshoz képest nem mutatnak lényeges változást. Ebből a megfigyelésből arra következtettünk, hogy a vizsgált pH-tartományban az [ML] komplex képződésén kívül 
más folyamat nem történik, illetve a monokomplex disszociációja pH 2 alatt sem (vagy csak elhanyagolható mértékben) következik be. A monokomplex képződésének tanulmányozására így az adott módszerekkel nincs lehetőség. Mindezek alapján [ML] komplex stabilitási állandója nem számolható, csupán képződésének alsó határértéke becsülhető meg. A rendszer további kiértékeléséhez ezért [Ru(II)- $\eta^{6}-p$-cimol]-tioallomaltolát komplex stabilitási szorzatát az így kapott értéken rögzítettük. Az alsó érték becslést az UV-látható fotometriás mérések alapján adtuk meg: $\lg \beta=13,4$, ha ennél kisebb lenne az állandó, akkor az már mérhető változást jelentene a rendszer spektrális sajátságaiban. A továbbiakban az ${ }^{1} \mathrm{H}$ NMR spektrumok és $\mathrm{pH}$-potenciometriás görbék kiértékelésénél az így becsült értéket vettük figyelembe.

Ugyanakkor $\mathrm{pH} \sim 6$ felett az UV-látható spektrumok karaktere változást mutat. Jelentős abszorbancia csökkenés figyelhető meg a 230-530 nm hullámhossz tartományban.

1:1 fémion-ligandum arány mellett rögzített $\mathrm{pH}$-függő ${ }^{1} \mathrm{H}$ NMR mérések megerősítették a pH-potenciometria és a fotometriás mérések alapján állított feltételezésinket (46. ábra). pH 2 - 5 tartományban csupán egyféle komplex van jelen az oldatban, a szabad ligandum és fémion jele nem jelenik meg a spektrumokon. $\mathrm{pH} 5$ felett a jelek intenzitása jelentős mértékben csökken, pH 6 felett pedig csapadék jelenik meg az oldatban.

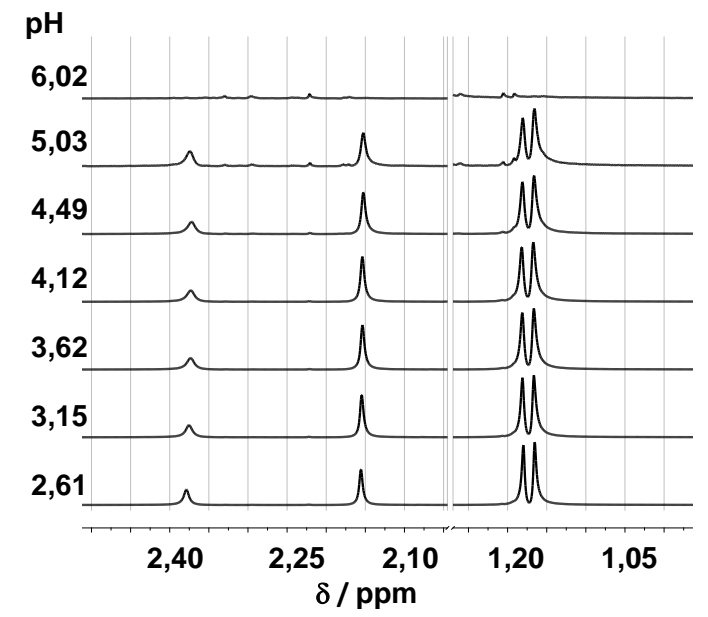

46. ábra: $\mathrm{A}\left[\mathrm{Ru}(\mathrm{II})-\eta^{6}-p\right.$-cimol]-tioallomaltol rendszer $\mathrm{pH}$-függö ${ }^{1} \mathrm{H}$ NMR spektrumainak alifás régiója. $\left(\mathrm{c}_{\mathrm{L}}=\mathrm{c}_{\mathrm{M}}=2 \times 10^{-3} \mathrm{M}, \mathrm{I}=0,2 \mathrm{M} \mathrm{KCl}, \mathrm{t}=25^{\circ} \mathrm{C}, 10 \% \mathrm{D}_{2} \mathrm{O}\right)$

Feltételezéseink szerint $\mathrm{pH} \sim 5$ felett elindul az [ML] komplex hidrolízise, ami vízben rosszul oldódó oligomer vagy polimer részecskék kialakulásához vezet.

Ligandum felesleg esetében azonban a rendszer az $(\mathrm{O}, \mathrm{O})$ és $(\mathrm{O}, \mathrm{N})$ donoratomos ligandumoktól eltérően viselkedik. A pH-potenciometriás mérések egyértelmủen azt mutatták, hogy ligandum felesleg mellett nem indul el a komplex disszociációja pH 10 felett sem, illetve csapadék sem jelenik meg az oldatban, ahogy azt pH 6 felett az 1:1 
fémion:ligandum arányú rendszerek titrálása esetén tapasztaltuk. Kétszeres ligandum felesleg mellett mért pH-függő NMR spektrumokon pedig olyan jelek megjelenését tapasztaltuk már pH 2-nél is, amik sem az 1:1 arányú rendszerben képződő monokomplexhez, sem a szabad ligandumhoz nem voltak rendelhetők. Biszkomplex képződését feltételeztük már savas tartományban is, és ennek igazolására spektrumsorozatokat vettünk fel adott $\mathrm{pH}$ értékeknél ( $\mathrm{pH} 3$ és 9) változó fémion-ligandum arányoknál. A biszkomplex képződésének folyamata a 47. ábra bemutatott $\mathrm{pH}$ 3-nál felvett spektrumsorozaton nyomon követhetö.

a.

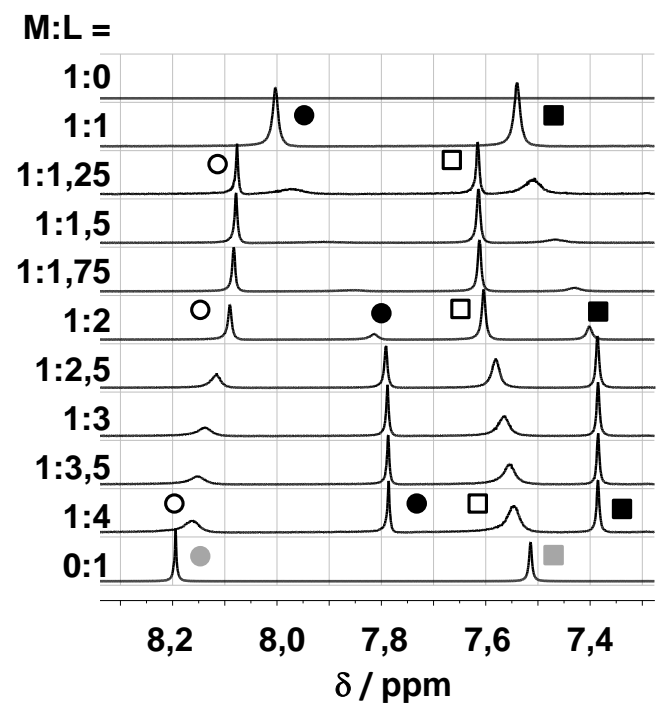

b.

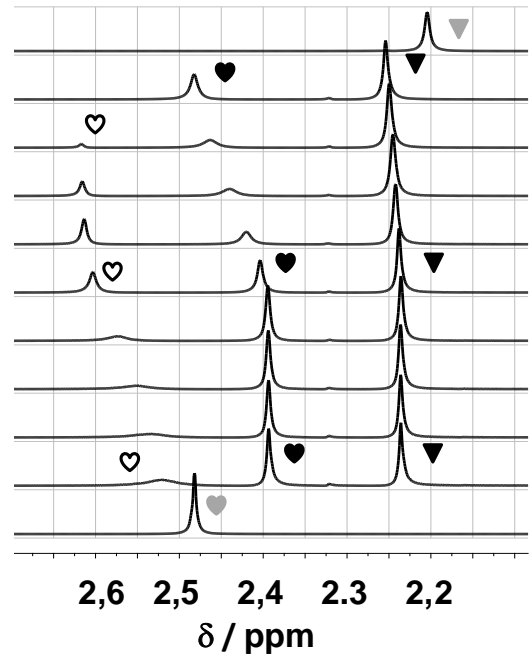

47. ábra: $\left[\mathrm{Ru}(\mathrm{II})-\eta^{6}-p\right.$-cimol]-tioallomaltol rendszer változó fémion-ligandum arány mellett rögzített spektrumainak (a) aromás és (b) alifás régiója $(\mathrm{pH}=3,0)$.

Lig $\mathrm{CH}(6) \bullet:(\mathrm{O}, \mathrm{S})$ koordináció, o: (S) koordináció és szabad ligandum •: szabad ligandum

Lig $\mathrm{CH}(3)$ : $(\mathrm{O}, \mathrm{S})$ koordináció, $\square:(\mathrm{S})$ koordináció és szabad ligandum $₫$ : szabad ligandum

Lig $\mathrm{CH}_{3}$ : $(\mathrm{O}, \mathrm{S})$ koordináció $\mathrm{O}$ : (S) koordináció és szabad ligandum $\mathrm{O}$ : szabad ligandum [Ru(II)- $\eta^{6}-p$-cimol] $\mathrm{Me}\left(\mathrm{CH}_{3}\right)$ : $\boldsymbol{\nabla}$ : kötött fémion $\nabla$ : nem kötött fémion $\left(c_{\mathrm{L}}=2,5 \times 10^{-3} \mathrm{M} ; \mathrm{t}=25^{\circ} \mathrm{C} ; \mathrm{I}=0,20 \mathrm{M} \mathrm{KCl} ; 10 \% \mathrm{D}_{2} \mathrm{O}\right)$

A rendszerben lejátszódó folyamatok a ligandumhoz tartozó protonok jelének követésével jól értelmezhetőek. Az 1:1 fémion-ligandum arány mellett felvett spektrumon csupán a monokomplexben kötött ligandum jelei látszanak, mely feltehetően kétfogú $(\mathrm{O}, \mathrm{S})$ ligandumként, kétfogú módon koordinálódik a $\left[\mathrm{Ru}(\mathrm{II})-\eta^{6}-p\right.$-cimol]-hoz. A ligandum felesleget 2:1 arányig növelve két új jel jelenik meg a spektrumon, ami egy új részecske a biszkomplex megjelenéséhez köthető. A két új jelet a $\left[\mathrm{ML}_{2} \mathrm{H}\right]$ komplexben kötött, kénatomon keresztül, egyfogú módon koordinálódó tioallomaltolhoz rendeljük. Helyzetük a spektrumon kb. 1:2 fém:ligandum arányig szinte változatlan. A [HL] feleslegét még tovább növelve azonban a két jel kiszélesedik, eltolódik a szabad ligandum jelei felé. 
Ebből az eltolódásból arra következtetünk, hogy gyors cserefolyamatok játszódnak le a szabad [HL] és a $\left[\mathrm{ML}_{2} \mathrm{H}\right]$ komplexben egyfogúként koordinálódott ligandum között.

Ha a 1:1 és 1:2 fémion-ligandum arány között felvett spektrumokat vizsgáljuk, megfigyelhetjük, hogy az eredetileg [ML] komplexben kétfogú módon koordinálódó ligandumhoz rendelhető jelek kiszélesednek, és eltolódnak, amely változás a monokomplex és a biszkomplex között lévő gyors cserefolyamathoz rendelhető:

$$
[\mathrm{ML}]+[\mathrm{HL}] \rightleftharpoons\left[\mathrm{ML}_{2} \mathrm{H}\right] .
$$

A folyamatra a kétfogúként koordinálódó ligandumhoz tartozó jelek spektrális változásai alapján állandót becsültünk, majd ennek segítségével határoztuk meg $\left[\mathrm{ML}_{2} \mathrm{H}\right]$ komplex látszólagos stabilitási állandóját. A 48. ábra a ligandum $\mathrm{CH}(6)$ (•)és $\mathrm{CH}(3)$ protonjaihoz rendelhető eltolódásokat mutatja a ligandum arányának növekedésével, illetve a jelek eltolódásából számolható koncentrációeloszlási diagramot, melynek segítségével az állandókat meg tudtuk határozni.

a.

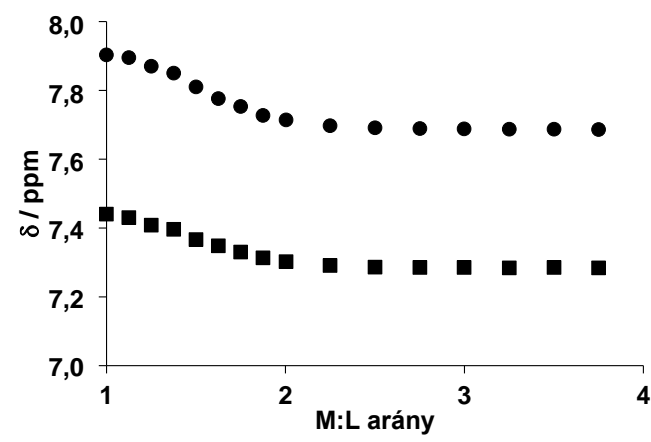

b.

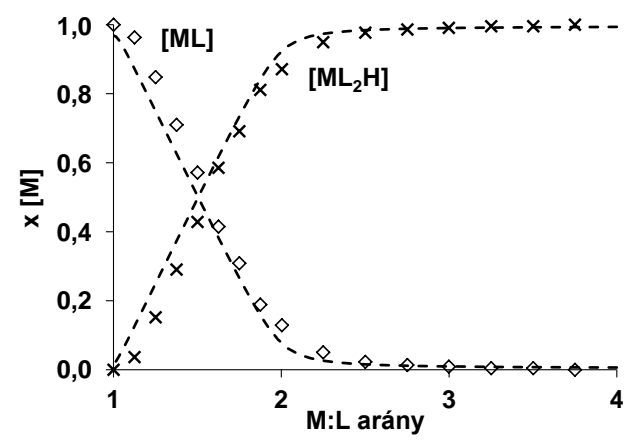

48. ábra: Ligandum $\mathrm{CH}(6)(\bullet)$ és $\mathrm{CH}(3)$ (•) protonjainak eltolódásai $\left[\mathrm{Ru}(\mathrm{II})-\eta^{6}-p\right.$-cimol]-tioallomaltol rendszerben, változó fémion-ligandum arány mellett rögzített spektrumai alapján $(\mathrm{pH}=3,0)(\mathrm{a})$.

A ligandum $\mathrm{CH}(6), \mathrm{CH}(3)$ és $\mathrm{CH}_{3}$ és jeleinek eltolódásai alapján számolt koncentrációeloszlás diagram ugyanebben a rendszerben $\left([\mathrm{ML}]: \diamond,\left[\mathrm{ML}_{2} \mathrm{H}\right]: \times\right)$

a számolt állandó alapján illesztett görbékkel együtt (szaggatott vonal) (b)

$\mathrm{Az}[\mathrm{ML}]$ monokomplex és [ML $\left.{ }_{2} \mathrm{H}\right]$ biszkomplex feltételezett szerkezete $\mathrm{pH}$ 3-nál a 49. ábra látható $(a, b)$.

a.

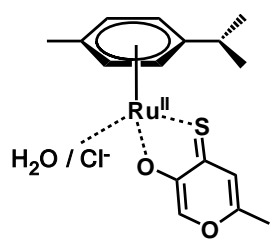

$[\mathrm{ML}]^{+/ 0}$ b.

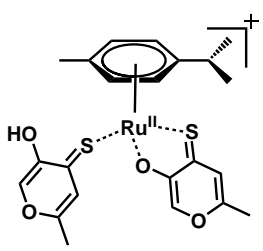

$\left[\mathrm{ML}_{2} \mathrm{H}\right]^{+}$ c.

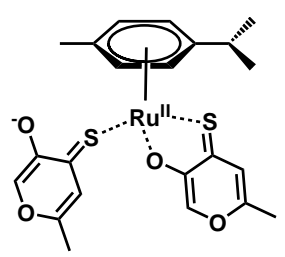

$\left[\mathrm{ML}_{2}\right]$

49. ábra: $\left[\mathrm{Ru}(\mathrm{II})-\eta^{6}-p\right.$-cimol $\left.\left(\mathrm{X}_{3}\right)\right]$-tioallomaltol rendszerben kialakuló komplexek feltételezett szerkezeti képletei $\left(\mathrm{X}=\mathrm{H}_{2} \mathrm{O}\right.$ vagy $\left.\mathrm{Cl}^{-}\right)$ 
Nagyobb pH-értékeknél az $\left[\mathrm{ML}_{2} \mathrm{H}\right]$ komplex deprotonálódni képes, ami $\left[\mathrm{ML}_{2}\right]$ kialakulását eredményezi (49. ábra, c). A deprotonálódási folyamatot jellemző $\mathrm{pK}\left[\mathrm{ML}_{2} \mathrm{H}\right]-$ értéket az 1:2 fémion-ligandum arány mellett változó $\mathrm{pH}$ értéknél felvett ${ }^{1} \mathrm{H} \mathrm{NMR}$ spektrumok változásából, illetve az $[\mathrm{ML}]$ és $\left[\mathrm{ML}_{2} \mathrm{H}\right]$ komplexek NMR spektrálisan meghatározott stabilitási állandóit rögzített értéken tartva a pH-potenciometriás mérések alapján is számolni tudtuk. A kapott pH-érték megfelelhet egy ilyen kinoidális elrendezésben lévő OH-csoport savasságának.

Tanszéki eredmények azt mutatják, hogy a $\left[\mathrm{Ru}(\mathrm{II})-\eta^{6}-p\right.$-cimol] tiomaltol ligandummal triszkomplexet is képes képezni, melyben mind a három tiomaltol ligandum feltehetően egyfogúként-, a kénatomon keresztül koordinálódik a [Ru(II)- $\eta^{6}-p$-cimol]-hoz. [Ru(II)- $\eta^{6}$ p-cimol]-tioallomaltol rendszer tanulmányozása során azonban ennek jelét nem tapasztaltuk. Többszörös ligandum felesleg mellett az ${ }^{1} \mathrm{H}$ NMR spektrumokon még nagyobb pH-értékeknél sem tapasztaltuk új komplex, vagy részecske megjelenésének jelét, amelyből triszkomplex jelenlétére következtethettünk volna (50. ábra).

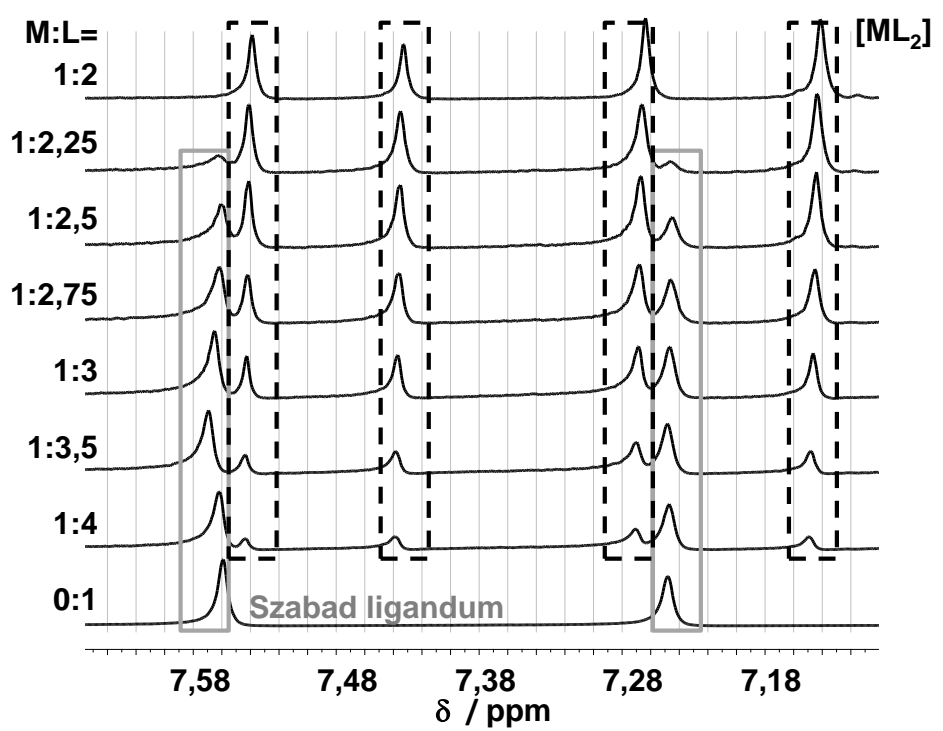

50. ábra: $\left[\mathrm{Ru}(\mathrm{II})-\eta^{6}-p\right.$-cimol]-tioallomaltol rendszerben $\mathrm{pH}$ 9-nél változó fémion-ligandum arány mellett rögzített ${ }^{1} \mathrm{H}$ NMR spektrumok aromás régiójának részlete. $\left(c_{\mathrm{L}}=2,5 \times 10^{-3} \mathrm{M} ; \mathrm{t}=25^{\circ} \mathrm{C} ; \mathrm{I}=0,20 \mathrm{M} \mathrm{KCl} ; 10 \% \mathrm{D}_{2} \mathrm{O}\right)$.

Annak érdekében, hogy a triszkomplex jelenlétének hiányát más módszerrel is megerösítsük UV-látható spektrumokat vettünk fel pH 9-nél különböző fémion-ligandum arány mellett (51. ábra). 


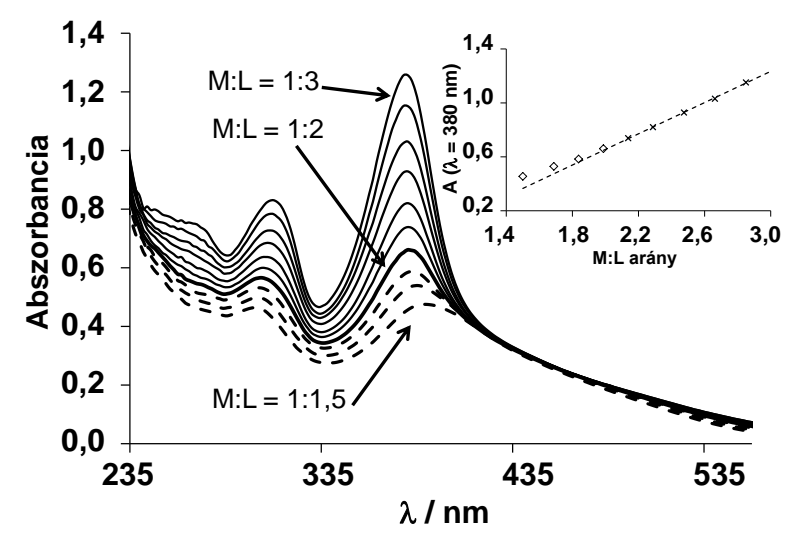

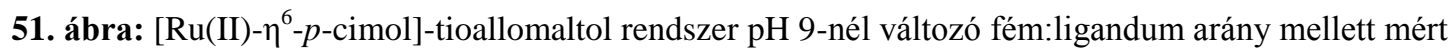
UV-látható spektrumai.

A beszúrt diagram az abszorbancia változását mutatja a ligandum felesleg függvényében $(\lambda=380 \mathrm{~nm})$. $\left(\mathrm{c}_{\mathrm{M}}=8 \times 10^{-5} \mathrm{M} ; \mathrm{c}_{\mathrm{L}}=1,2 \times 10^{-4}-2,4 \times 10^{-4} \mathrm{M} ; \mathrm{t}=25,0{ }^{\circ} \mathrm{C} ; \mathrm{I}=0,20 \mathrm{M} \mathrm{KCl}\right)$.

A ligandum mennyiségét 1:1,5 aránytól 1:2 arányig növelve a spektrumok maximum értékei eltolódnak rövidebb hullámhossz értékek felé. Tovább növelve a ligandum felesleget az görbék abszorbancia maximum értékei már nem tolódnak el, alakjuk hasonló a ligandum fajlagos abszorbancia görbéihez, csupán intenzitásuk változik lineárisan a ligandum koncentrációjának növekedésével, amely lineáris növekedést fémion-mentes rendszer esetén is tapasztalnánk.

A változó fémion-ligandum arány mellett $\mathrm{pH}$ 9-nél rögzített UV-látható és ${ }^{1} \mathrm{H}$ NMR spektrumok alapján azt gondoljuk, 1:2 fémion-ligandum arány felett már nem képződik új típusú részecske az oldatban.

Hasonlóan a többi rendszerhez, vizsgálatainkat tioallomaltol esetén is tanulmányoztuk [ML] komplex harmadik koordinációs helyén történő klorido/akva ligandumcserét. 1:1 fémion-ligandum arány mellett $\mathrm{pH}$ 2-nél vettünk fel ${ }^{1} \mathrm{H}$ NMR spektrumokat változó kloridion koncentráció mellett. Hasonlóan a hidroxi-piron ligandumokhoz a két részecske az NMR időskálán gyors csereegyensúlyban van egymással, a két részecske átlagjelét látjuk. A jelek eltolódásainak mértékéből becsültük meg a

$$
\left[\mathrm{ML}\left(\mathrm{H}_{2} \mathrm{O}\right)\right]^{+}+\mathrm{Cl}^{-} \rightleftharpoons[\mathrm{MLCl}]+\mathrm{H}_{2} \mathrm{O}
$$

folyamatra jellemző egyensúlyi állandót $\left(\lg \mathrm{K}^{*}=0,71(1)\right)$ amely nagy hasonlóságot mutat $(\mathrm{O}, \mathrm{O})$ donoratomos ligandumot tartalmazó rendszereinkhez (lásd 9. táblázat, 58. oldal). 


\subsubsection{Legfontosabb következtetések [Ru(II)- $\eta^{6}-p$-cimol] komplexek oldategyensú- lyáról}

A vizsgált ligandumok [Ru(II)- $\eta^{6}-p$-cimol] kötő sajátságai jól összehasonlíthatók, ha megvizsgáljuk, hogy a monokomplexek egyensúlyi állandói hogyan függenek a ligandumok proton disszociációs állandóitól (52. ábra).

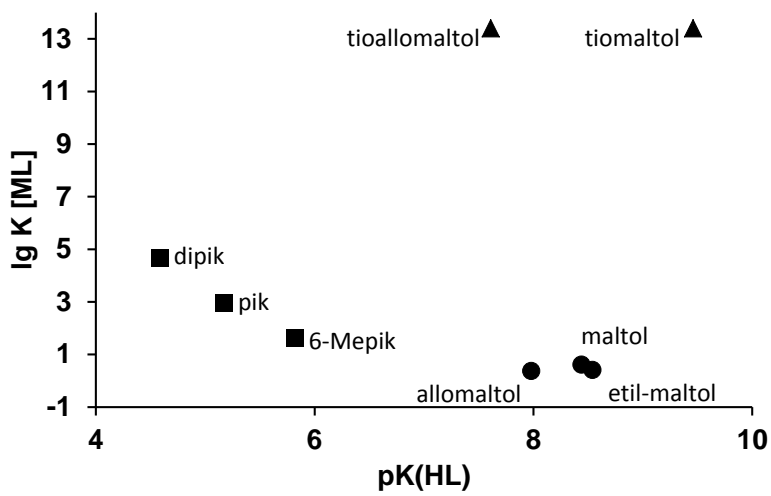

52. ábra: Korrelációs diagram $\left[\mathrm{Ru}(\mathrm{II})-\eta^{6}-p\right.$-cimol $](\mathrm{O}, \mathrm{O}),(\mathrm{O}, \mathrm{N})$ és $(\mathrm{O}, \mathrm{S})[\mathrm{ML}]$ komplexeinek egyensúlyi állandója (lg K [ML]) és a ligandumok pK (HL) értéke között

$\left(\left[\mathrm{Ru}(\mathrm{II})-\eta^{6}-p\right.\right.$-cimol]-maltolát származtatott állandója $\left.{ }^{181}\right)$

A diagramról leolvasható, hogy a legkisebb stabilitása az $(\mathrm{O}, \mathrm{O})$ komplexeknek van, közepes stabilitású komplexeket képeznek az $(\mathrm{O}, \mathrm{N})$ donoratomos ligandumok, a tioszármazékok stabilitása pedig kiemelkedően nagy, még a becsült $\lg \mathrm{K}$ [ML] minimum értékének alapján is. A stabilitási sorrend közelítőleg korrelál a komplexek rákos sejteken vizsgált citotoxicitásával (12. táblázat). A legkisebb stabilitású $(\mathrm{O}, \mathrm{O})$ donoratomos allomaltol komplex alig toxikus, míg a maltol és az etil-maltol [Ru(II)- $\eta^{6}-p$-cimol] komplexének mérsékelt antiproliferatív hatása van. A biológiai hatás valószínüleg összefüggésbe hozható a komplexek stabilitásával. Eredményeink szerint hidroxi-piron származékok stabilitása nem elég nagy, ennek megfelelően fiziológiás pH-n a komplex disszociál, így valószínüleg ennek tudható be a vegyes komplex a $\left[\mathrm{Ru}(\mathrm{II})-\eta^{6}-p\right.$-cimol] $\mathrm{IC}_{50}$ értékét alig (vagy nem) meghaladó aktivitása. Az $(\mathrm{O}, \mathrm{N})$ donoratomos pikolinsav komplexének stabilitása nagyobb, és ezzel összefüggésben a rákos sejtekre is mérgezőbb hatású. A dipik [ML] komplexének stabilitása meghaladja a pik-ét, itt a biológiai hatás hiánya valószínúleg a víz-klorid ligandum arány eltolódása az akvakomplex irányába, illetve a kloridokomplexek negatív töltésének tudható be, amely a 4.3.2.2 fejezetben részletesen kifejtésre került. A hidroxi-tiopiron származékok komplexeinek alacsony $\mathrm{IC}_{50}$ értékét, azaz nagy toxicitását a kiemelkedően nagy stabilitása okozhatja. 
12. táblázat: A vizsgált ligandumok $\left[\mathrm{Ru}(\mathrm{II})-\eta^{6}-p\right.$-cimol] komplexeinek $\mathrm{IC}_{50}$ értéke különböző rákos sejtvonalakon

\begin{tabular}{|c|c|c|c|c|}
\hline & & $\mathrm{IC}_{50}(\mu \mathrm{M})$ & Rákos sejtvonal & Ref. \\
\hline & {$\left[\mathrm{Ru}(\mathrm{II})-\eta^{6}-p\right.$-cimol $]$} & $>300 / 211$ & FemX/HeLa & 144 \\
\hline \multirow{3}{*}{$(\mathbf{0 , 0})$} & allomaltol & $239 / 359 / 518$ & CH1/SW480/A549 & \multirow{2}{*}{144} \\
\hline & etil-maltol & $81 / 165 / 389$ & CH1/SW480/A549 & \\
\hline & maltol & $81 / 159 / 482$ & CH1/SW480/A549 & 154 \\
\hline \multirow{3}{*}{$(\mathbf{O}, \mathbf{N})$} & pik & $95 / 78 / 82$ & EA.hy926/MS1/HeLa & 146 \\
\hline & 6-Mepik & - & - & - \\
\hline & dipik & $>300 />300$ & FemX/HeLa & 152 \\
\hline \multirow{2}{*}{$(\mathbf{O}, \mathbf{S})$} & tiomaltol & $13 / 5,1$ & CH1/SW4 & \multirow{2}{*}{154} \\
\hline & tioallomaltol & $35 / 20$ & CH1/SW4 & \\
\hline
\end{tabular}

Az eredmények azt mutatják, hogy a kétfogú ligandumok stabilitása és rákos sejtvonalakon való biológiai aktivitása között összefüggés van. Ezért a továbbiakban olyan ligandumok [Ru(II)- $\eta^{6}-p$-cimol] komplexeit érdemes vizsgálni, melyek erős koordinációs kötés kialakítására képesek a központi Ru(II)ionnal. Ilyen ligandumok a most vizsgált $(\mathrm{O}, \mathrm{S})$ hidroxi-tiopiron származékok, vagy az $(\mathrm{N}, \mathrm{N})$ illetve $(\mathrm{N}, \mathrm{S})$ donoratomos ligandumok lehetnek. ${ }^{149,206,207}$

\subsection{Hidroxi-piridinkarbonsavak és $\left[\operatorname{Ru}(I I)-\eta^{6}-p\right.$-cimol] komplexek kölcsönhatása humán szérum albuminnal}

Amint azt a 2.3. fejezetben tárgyaltuk, a potenciális gyógyszermolekulák biológiai rendszerekben való viselkedésének fontos eleme a szervezetben való szállítódásuk folyamatának vizsgálata. A vérszerumban való szállítás folyamatának jellemzésében első lépésként a legvalószínűbb szérumbeli kötőmolekulával, az albuminnal való kölcsönhatását tanulmányoztuk.

\subsubsection{Hidroxi-piridinkarbonsavak kölcsönhatása HSA-val}

DQ5, DQ715, DQ6, DQ716 és DT726 hidroxi-piridinkarbonsav ligandumok-humán szérum albumin (HSA) kölcsönhatás tanulmányozása során egyedül a DT726 molekula esetében sikerült jelentős mértékü kölcsönhatást egyértelmüen kimutatnunk. DQ5 és DQ715 ligandumok albuminhoz való kötődését spektrofluorimetriás vizsgálatok elemzése után zártuk ki az alábbi megfontolások alapján.

A DQ5 és DQ715 ligandumok 280 és 295 nm-es hullámhosszúságú fénnyel gerjesztve 320-340 nm tartományban még csupán kismértékü emissziót mutatnak az albumin emissziójához képest, az emissziós maximumuk közelében azonban az már nem 
elhanyagolható (53. ábra). Ezért a kölcsönhatás tanulmányozását két oldalról is megközelíthetjük. Vizsgálhatjuk a HSA molekulára jellemzős emissziós intenzitás változását 320-340 nm között, illetve 360-400 nm-es tartományban, ahol azonban a ligandumok emissziójával is számolnunk kell.

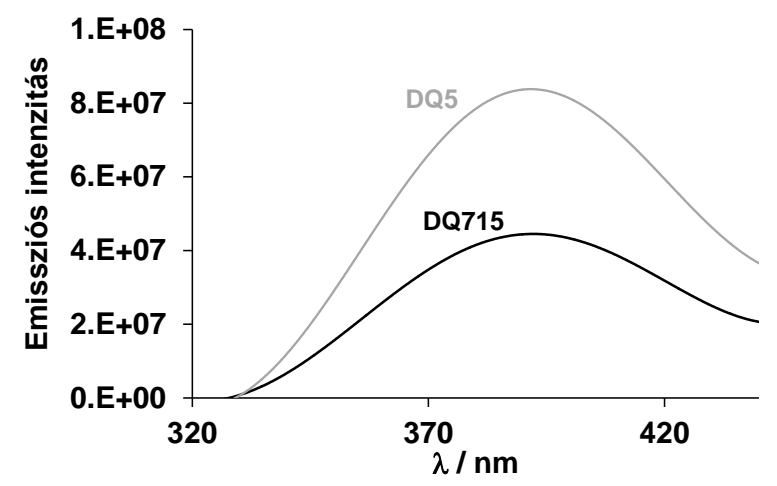

53. ábra: Korrelációs DQ5 és DQ715 moláris emissziós spektruma; $\mathrm{pH}=7,4 ; \mathrm{t}=25^{\circ} \mathrm{C} ; \lambda_{\mathrm{EX}}=280 \mathrm{~nm}$

A HSA-ra jellemző intenzitás maximum felöl vizsgálva a kérdést, azt tapasztaljuk, hogy növekvő ligandum arány nem okoz intenzitásváltozást 24 óra inkubációs idő után 280 és 295 nm besugárzási hullámhossz alkalmazása során sem. Másrészt különböző arányú ligandum-HSA oldatokban a ligandum koncentrációjának növelésével 389 nm-en a fluoreszenciás intenzitás lineárisan nő, melynek meredeksége megegyezik a ligandumot azonos koncentrációban tartalmazó, azonban HSA-mentes oldat emissziójának változásával (54. ábra).

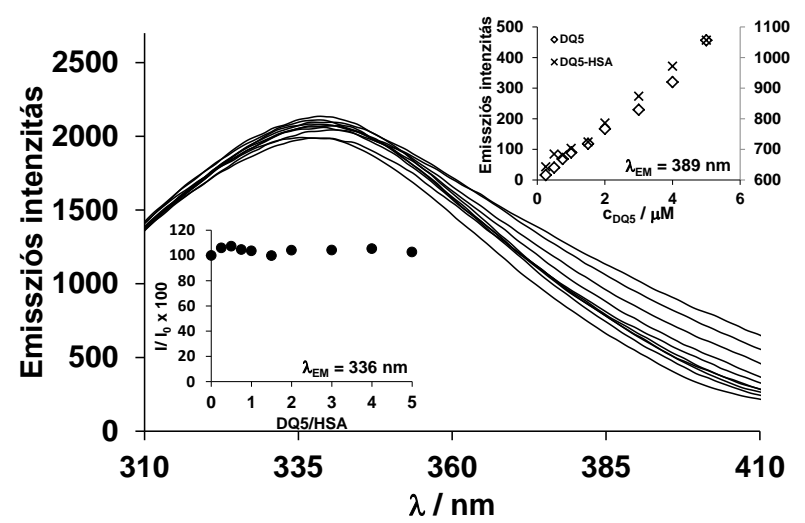

54. ábra: Különböző arányú DQ5-HSA minták spektrofluorimetriás spektrumai 24 óra inkubációs idő után. A felsö beszúrt diagram az emisszió változását mutatja $\lambda_{E M}=389 \mathrm{~nm}$ hullámhossznál DQ5-HSA és DQ5 HSA-mentes oldatában; alsó beszúrt diagram: DQ5-HSA intenzitásváltozása az arány változásának függvényében 24 óra után

$\left(\lambda_{\mathrm{EM}}=336 \mathrm{~nm}\right) ; \mathrm{pH}=7,4 ; \mathrm{t}=25^{\circ} \mathrm{C} ; \lambda_{\mathrm{EX}}=280 \mathrm{~nm} ; \mathrm{c}_{\mathrm{HSA}}=0,5 \mu \mathrm{M} ; \mathrm{DQ} 5-\mathrm{HSA}=1: 0-1: 10$

Ha a ligandum emissziójából származó intenzitás értékkel korrigáljuk a spektrumokat, nem tapasztalunk változást, azaz nem alakul ki kölcsönhatás a ligandum és az albumin molekula között (55. ábra). 


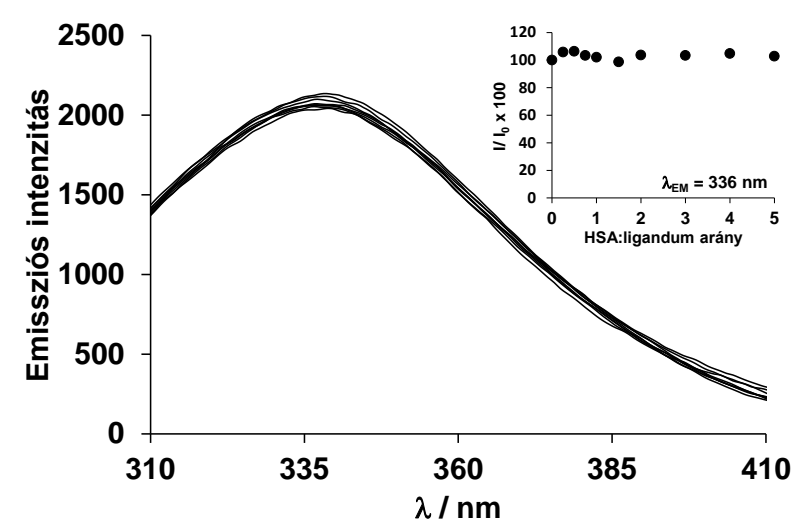

55. ábra: DQ5-HSA oldatokban mért spektrofluorimetriás spektrumok DQ5 fluoreszcenciás emissziójával korrigált görbéi 24 óra inkubációs idő után.

Beszúrt diagram: DQ5-HSA intenzitásváltozása az arány változásának függvényében 24 óra után

$\left(\lambda_{\mathrm{EM}}=336 \mathrm{~nm}\right) ;\left(\mathrm{pH}=7,4 ; \mathrm{t}=25^{\circ} \mathrm{C} ; \lambda_{\mathrm{EX}}=280 \mathrm{~nm} ; \mathrm{c}_{\mathrm{HSA}}=0,5 \mu \mathrm{M} ; \mathrm{DQ} 5-\mathrm{HSA}=1: 0-1: 10\right)$

DQ716 és DQ6 ligandum-HSA közötti kölcsönhatást ultraszüréssel vizsgáltuk, és zártuk ki annak valószínüségét. A szürletben lévő ligandum koncentrációját spektrofotometriásan mértük, és azt tapasztaltuk, hogy az megegyezik a kiindulási oldatok koncentrációjával, azaz egyik ligandum sem kötődött az albuminhoz.

Ugyanakkor a DT726 ligandum és az albumin közötti kölcsönhatást mindkét módszerrel sikerült kimutatnunk, és kvantitatívan ki is értékelnünk. Spektrofluorimetriás módszer alkalmazásánál a ligandum emisszióját követtük, mivel a HSA gerjesztési hullámhosszain a DT726 is emittál, azonban a ligandumot gerjesztve $\lambda_{\mathrm{EX}}=320 \mathrm{~nm}$-en az albuminnak nincs fluoreszcens aktivitása.

a.

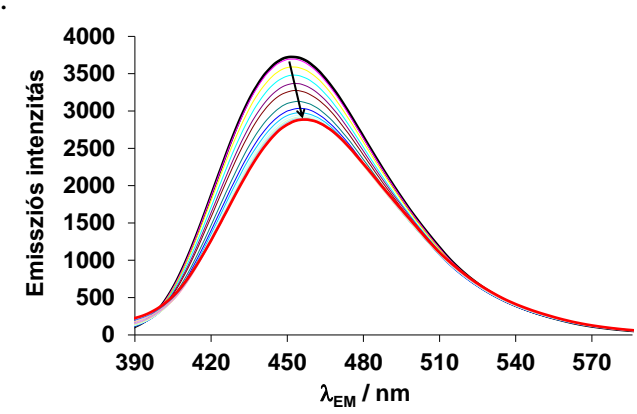

b.

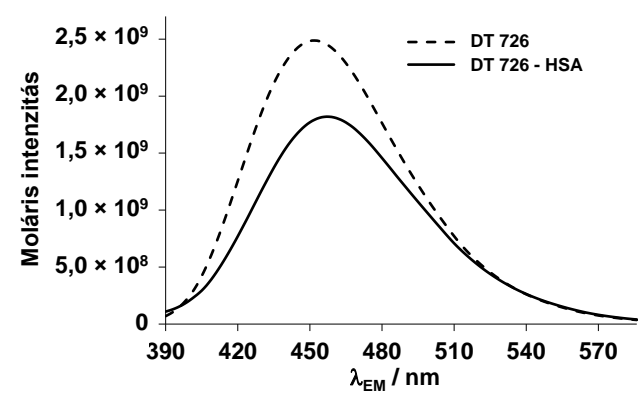

56. ábra: DT726 fluoreszcens emissziójának változása a HSA koncentrációjának növekedésével DT726 : HSA $=1: 0-1: 6, c_{\text {DT726 }}=1.5 \times 10^{-6} \mathrm{M}$

(a); DT726 és DT726-HSA komplex számolt moláris emissziós intenzitása

(b); $\mathrm{pH}=7,4 ; \mathrm{t}=25^{\circ} \mathrm{C} ; \lambda_{\mathrm{EX}}=320 \mathrm{~nm}, 20 \mathrm{mM}$ HEPES puffer

A HSA-ligandum arány változásával az $\lambda_{\mathrm{EM}}(\max )$ a $452 \mathrm{~nm}$ induló értékből nagyobb hullámhosszak felé tolódik el $\left(\lambda_{\mathrm{EM}}(\max )=457 \mathrm{~nm}\right)$, melynek oka hogy a ligandum emissziója megváltozik a HSA-hoz való kötődése során (56. ábra).

A PSEQUAD program segítségével számolt egyedi spektrumok alapján megállapítható, hogy a várakozásnak megfelelően a HSA-DT726 adduktum kisebb intenzitással emittál és 
az emissziós intenzitásának maximuma a nagyobb hullámhosszak irányába tolódik el. Az 56. ábrán látható spektrális változások kvantitatív kiértékelésével a 13. táblázatban feltüntetett látszólagos kötési/stabilitási állandót sikerült számítanunk a DT726-albumin kölcsönhatásra.

Az ultraszüréses és az azt követő UV-látható spektrofotometriás mérések eredményei azt mutatják, hogy megfelelően nagy ligandum felesleg mellett a HSA molekula akár négy ligandum megkötésére is képes lehet. A különböző HSA-ligandum arányoknál a szürletben lévő nem kötött ligandum koncentrációja alapján következtettünk a kötött ligandum mennyiségére, és ez alapján látszólagos stabilitási állandókat határoztunk meg a PSEQUAD program segítségével (13. táblázat).

\begin{tabular}{|c|c|c|}
\hline $\begin{array}{l}\text { 13. táblázat: } \\
\text { komplexek } \\
\text { meghatározott } \\
(\mathrm{pH}=7,40 ; 0,10\end{array}$ & $\begin{array}{l}\text { HSA-ligandun } \\
\text { különbözö } \\
\text { átszólagos st } \\
\text { M HEPES pu }\end{array}$ & $\begin{array}{l}(\mathrm{L}=\mathrm{DT} 726) \\
\text { módszerekkel } \\
\text { bilitási állandói } \\
\left.\text { er; } \mathrm{t}=25 \mathrm{C}^{\circ}\right)\end{array}$ \\
\hline Spektrofluorin & netria & \\
\hline & (HSA)-L & $5,79(1)$ \\
\hline Ultraszürés-U & V-látható spe & trofotometria \\
\hline & (HSA)-L & $4,83(9)$ \\
\hline & $(\mathbf{H S A})-\mathbf{L}_{2}$ & $9,1(3)$ \\
\hline & $(\mathbf{H S A})-\mathbf{L}_{3}$ & $13,1(1)$ \\
\hline & $(\mathbf{H S A})-\mathbf{L}_{4}$ & $16,1(6)$ \\
\hline
\end{tabular}

${ }^{\mathrm{a} A}$ zárójelben az állandókra számolt utolsó jegy bizonytalansága van feltüntetve.

Az így meghatározott HSA-DT726 komplexre számolt stabilitási állandó egy nagyságrenddel kisebb volt, mint a fluorimetriás mérésekből számolt. Ennek oka lehet, hogy az ultraszüréses vizsgálatok során mM-os, míg spektrofluorimetriás körülmények között a $\mu \mathrm{M}$-os koncentrációban tudjuk a rendszert tanulmányozni. Ilyen híg oldatban csekély a valószínűsége annak, hogy HSA- $\mathrm{L}_{2-4}$ komplex alakuljon ki. Spektrofluorimetriás mérésekkel csupán a HSA-L komplex látszólagos stabilitási állandóját tudtuk meghatározni. Habár kis valószínüséggel több ligandumú komplexek képződésére is van lehetőség ilyen híg oldatokban, ezt a számolás során nem vettük figyelembe. Másrészt az ultraszüréses mérések esetében az egyensúly megváltozásának lehetőségét sem szabad figyelmen kívül hagyni. Azt sem szabad figyelmen kívül hagyni, bár ez a megadott állandók hibájában nem tükröződik, hogy a mM-os koncentráció tartományban végzett méréseinknél a kísérletek előkészítésének hibájából adódó pontatlanság talán nagyobb lehet. A számolt HSA-DT726 stabilitási állandó nagyságrendje alapján megállapítható, 
hogy az albumin molekula alkalmas lehet a ligandum szervezetben való szállítására. Hasonló kötési állandót állapítottak a dipik, 6-Mepik ligandumok, ${ }^{208}$ illetve számos antibiotikum (tetraciklinek, flavonoidok, fluorokinolin származékok) esetében is. ${ }^{209,210,211,212}$

\subsection{2. [Ru(II)- $\eta^{6}-p$-cimol], [Ru(II)- $\eta^{6}-p$-cimol]-pikolinát és [Ru(II)- $\eta^{6}-p$-cimol]-etil-} maltolát kölcsönhatásának vizsgálata HSA-val

A $\left[\mathrm{Ru}(\mathrm{II})-\eta^{6}-p\right.$-cimol] és komplexeinek oldatspeciációjának megismerése után megkezdtük a HSA-val való kölcsönhatás vizsgálatát, amely vizsgálatok jelenleg is folynak. Spektrofluorimetriásan vizsgáltuk magának a $\left[\mathrm{Ru}(\mathrm{II})-\eta^{6}-p\right.$-cimol] kötődését az albuminhoz az I. kötőhelyen, (N,O) donoratomos komplexek közül a [Ru(II)- $\eta^{6}-p$-cimol]pikolinát, míg $(\mathrm{O}, \mathrm{O})$ típusú ligandumok esetében a $\left[\mathrm{Ru}(\mathrm{II})-\eta^{6}-p\right.$-cimol]-etil-maltolát komplexét választottuk modellvegyületként.

A mérésekből kiderült, hogy mind a tirozin, mind a triptofán214 aminosavakat gerjesztve az emissziós spektrumok intenzitása a növekvő Ru(II)komplex felesleg hatására csökken, ami kölcsönhatás kialakulására utal. Az egyensúly $\left[\mathrm{Ru}(\mathrm{II})-\eta^{6}-p\right.$-cimol] és pikolinátkomplexe esetében is viszonylag lassan áll be, 2 és 24 órás inkubációs idejü minták intenzitás értékei között még jelentős különbség van, azonban a 48 órás minták vizsgálata során már nem tapasztaltunk változást, azaz a 24 óra elegendő volt az egyensúly kialakulására.

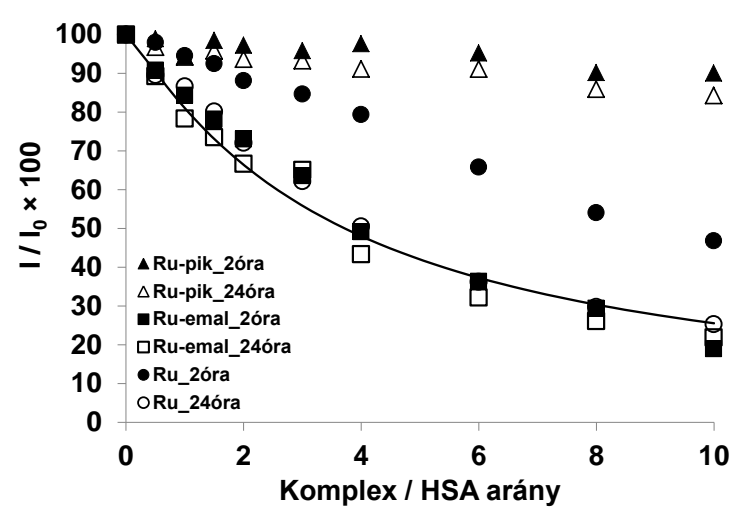

57. ábra: $\left[\mathrm{Ru}(\mathrm{II})-\eta^{6}-p\right.$-cimol]-pikolinsav-HSA ( $\left.\boldsymbol{\Delta} \Delta\right),\left[\mathrm{Ru}(\mathrm{II})-\eta^{6}-p\right.$-cimol]-etil-maltol-HSA ( $\left.\square\right)$ és $\left[\mathrm{Ru}(\mathrm{II})-\eta^{6}-p\right.$-cimol]-HSA $(\bullet \circ)$ intenzitásváltozása az arány változásának függvényében 2 óra $(\boldsymbol{\Delta} \bullet \bullet)$ és egy nap $(\Delta \square \circ)$ inkubációs idő elteltével.

(A folytonos vonal a meghatározott lg $K^{\prime}$ alapján illesztett görbe, $\lg K_{[R u(I I)-\eta 6-p-c i m o l]-H S A}^{\prime}=5,81 \pm 0,01$ ) $\mathrm{pH}=7,4 ; \mathrm{t}=25^{\circ} \mathrm{C} ; \lambda_{\mathrm{EX}}=295 \mathrm{~nm} ; \mathrm{c}_{\mathrm{HSA}}=0,5 \mu \mathrm{M} ;$ HSA $:$ komplex $=1: 0,5-1: 10$ 
A mért intenzitások százalékos értékét összehasonlítva megállapítható, hogy a csökkenés mértéke 1 nap után is a [Ru(II)- $\eta^{6}-p$-cimol] és [Ru(II)- $\eta^{6}-p$-cimol]-etil-maltolát komplex esetében jelentősen nagyobb, mint ahogy azt a $\left[\mathrm{Ru}(\mathrm{II})-\eta^{6}-p\right.$-cimol]-pikolinsav komplexnél tapasztaltuk (57. ábra). Ebböl arra következtettünk, hogy a [Ru(II)- $\eta^{6}-p$-cimol] pikolinsavval képzett komplexének viszonylag nagy stabilitása miatt a pik ligandum koordinációja gátolja a $\left[\mathrm{Ru}(\mathrm{II})-\eta^{6}-p\right.$-cimol] kötődését az albuminhoz. Azonban, míg a $\left[\mathrm{Ru}(\mathrm{II})-\eta^{6}-p\right.$-cimol] etil-maltol ligandummal képzett komplexét tartalmazó mintákban az egyensúly már két óra alatt teljesnek mondható, a [Ru(II)- $\eta^{6}-p$-cimol]-nál ez csak hosszabb inkubációs idő után érhető el. A jelenséget valószínűleg az magyarázza, hogy maga a [Ru(II)- $\eta^{6}-p$-cimol] 7,4-es pH értéken $\mathrm{Ru}_{2} \mathrm{H}_{-3}$ kétmagvú komplex formájában van jelen, amely forma lassíthatja a [Ru(II)- $\eta^{6}-p$-cimol]-HSA adduktum kialakulását. Az etil-maltolát komplexben gyengén kötött [Ru(II)- $\eta^{6}-p$-cimol]-ért a HSA mérhetően verseng, és könnyen képes kiszorítani azt az etil-maltolát vegyes komplexéből. A [Ru(II)- $\eta^{6}-p$-cimol] kötődését bizonyítja az is, hogy 24 óra után a görbék lefutása megegyezik az eredetileg [Ru(II)- $\eta^{6}-p$ cimol]-t és [Ru(II)- $\eta^{6}-p$-cimol]-etil-maltolt tartalmazó oldatban. Tehát feltételezhetően nem a $\left[\mathrm{Ru}(\mathrm{II})-\eta^{6}-p\right.$-cimol]-etil-maltolát komplexet képes kötni az albumin molekula, hanem az etil-maltol ligandumot kiszorítva alakít ki kölcsönhatást a [Ru(II)- $\eta^{6}-p$-cimol]lal. Feltételezésünket igazolja a [Ru(II)- $\eta^{6}-p$-cimol]-deferipron komplex-HSA kölcsönhatásának vizsgálata is. A deferipron $\left[\mathrm{Ru}(\mathrm{II})-\eta^{6}-p\right.$-cimol]-lal való komplexképződése az irodalomból ismert. ${ }^{181} \mathrm{~A}$ komplex stabilitása nagyobb, mint a [Ru(II)- $\eta^{6}-p$-cimol]-etilmaltolát, illetve allomaltolát komplex stabilitása, és a disszociációja sem indul meg pH 10 alatt. Ultraszüréses méréssel megállapítottuk, hogy a HSA a [Ru(II)- $\eta^{6}-p$-cimol]-deferipron komplexet tartalmazó oldatban képes a $\left[\mathrm{Ru}(\mathrm{II})-\eta^{6}-p\right.$-cimol]-hoz kötődni, míg a leszorított deferipron a szürletben jelenik meg. A mérési eredményekből kvantitatív kiértékelést csak a [Ru(II)- $\eta^{6}-p$-cimol]-HSA kölcsönhatás leírására végeztünk. A $295 \mathrm{~nm}$ hullámhosszal gerjesztett emissziós intenzitás csökkenésből számolt kvencselési állandó $\left(\lg \mathrm{K}^{\prime}=\right.$ $5,81 \pm 0,01)$ alapján a HSA az I-es kötőhely közelében viszonylag erősen képes kötni a [Ru(II)- $\eta^{6}-p$-cimol] molekulát. Hogy a kötődés a hidrofób zsebbe történik-e, vagy koordinációs kötés valósul meg a zseb közelében lévő hisztidin oldalláncal jelenleg is vizsgálat tárgya, bár a lassú kölcsönhatás kialakulásából azt feltételezzük, hogy nem másodlagos kötőerők játszanak szerepet, hanem a $\left[\mathrm{Ru}(\mathrm{II})-\eta^{6}-p\right.$-cimol $]$ és a HSA egyik (feltehetőleg hisztidin) aminosava között alakul ki koordinációs kötés. 


\section{5. Összefoglalás}

Ph.D tanulmányaim során olyan kutatási témákban vettem részt, melyek két súlyos, napjainkban is sokszor gyógyíthatatlan betegség - a rák és az Alzheimer-kór terápiájában próbál újlehetőségeket kifejleszteni. A neurodegeneratív elváltozások felöl közelítve a problémát a szervezet fémion háztartásának zavara az, amely a betegség kialakulásához vezet, mely megfelelő kelátorok alkalmazásával korrigálható lehet. Rákellenes terapeutikumok kifejlesztése során pedig a fémiontartalmú komplexek a rákos sejtekre kifejtett citotoxikus hatásukkal segítséget jelenthetnek a gyógyulásban.

Fémkötő kelátorok kifejlesztésére és vizsgálatára irányuló témában a Padovai Egyetemmel közösen olyan új kelátképző ligandumokat keresünk, melyek hatékonyan képesek felvenni a versenyt a megkötött fémionokért az Alzheimer-kóros betegek agyában a $\beta$-amiloid fehérjékkel, így megakadályozva a toxikus oligomerek, illetve lerakódások képződését. Fémkötő ligandumokat az Al(III), Fe(III), Cu(II) felesleg eltávolításában jelenleg is alkalmaznak (deferipron, dezferrioxamin, D-penicillamin) azonban alkalmazásuk számos mellékhatással jár. A hidroxi-piridinkarbonsav molekulák viszonylag csak magas koncentrációban citotoxikusak $\left(\mathrm{IC}_{50}>1 \mathrm{mM}\right)$, és megfelelő szubsztituáltság esetén képesek lehetnek elvonni a $\mathrm{Fe}$ (III) és $\mathrm{Al}(\mathrm{III})$, illetve $\mathrm{Cu}$ (II)ionokat a $\beta$-amiloid aggregátumokból, anélkül, hogy létfontosságú biomolekuláktól vonnák el a fémionokat a szervezetben, megzavarva ezzel müködésüket.

A hidroxi-piridinkarbonsav molekulák $\mathrm{Fe}$ (III) és $\mathrm{Al}(\mathrm{III})$ fémionokkal mono, bisz és triszkomplekek kialakítására képesek. A komplexek stabilitása a legtöbb ligandum esetében nem elég erős ahhoz, hogy a Fe(III)-oldatban megakadályozza a fémionok hidrolízisét fiziológiás $\mathrm{pH}$ értéken ( $\mathrm{pH} 7,4)$, azonban négy ligandum, a DT1, a DT712, a DQ716 és az általam is vizsgált DQ715 fiziológiás körülmények között is képes arra, hogy a Fe(III)ionokat oldatban tartsa. Al(III)-al azonban minden ligandum képes komplexet alkotni, és az $\mathrm{Al}(\mathrm{OH})_{3}$ leválását megakadályozni pH 7,4-ig. Legerősebb $\mathrm{Al}(\mathrm{III})$ komplexei az 5. és 6. pozícióban metilált hidroxi-piridin karbonsavaknak képződnek.

A ligandumok $\mathrm{Cu}(\mathrm{II})$ és $\mathrm{Zn}(\mathrm{II})$ ionokkal, illetve humán szérum albuminnal való kölcsönhatásának tanulmányozását a Szegedi Tudományegyetemen végeztem. A ligandumok hard jellege folytán a „borderline” fémionokkal kisebb stabilitású komplexet képeznek. A komplexképződést elsősorban pH-potenciometriás mérésekkel vizsgáltuk, amit DQ5 és DQ715 ligandumok esetében UV-látható és ${ }^{1} \mathrm{H}$ NMR vagy ESR mérésekkel egészítettünk ki. Megállapítottuk, hogy a vizsgált ligandumok közül a DQ716 az, amely a 
$\beta$-amiloid fehérjékkel nagyságrendben hasonló stabilitású komplexet képez réz(II)ionokkal, így akadályozhatja a $\beta$-amiloid fehérjék rézion-indukálta aggregációját. A cinkkomplexek stabilitása olyan kicsi, hogy a vizsgált ligandumok valószínüleg nem befolyásolják a szervezet cink-homeosztázisát.

Néhány ligandum albuminnal való kölcsönhatást spektrofluorimetriás és ultraszűrésesUV-látható spektrofotometriás módszerekkel vizsgáltuk. A DQ (4-hidroxi-3piridinkarbonsav származékok) ligandumokkal nem tudtunk kimutatni kölcsönhatást, csupán a DT726 molekula, amely 3-hidroxi-4-piridinkarbonsav származék volt képes a HSA-val kötést kialakítani. Ultraszüréses-UV-látható spektrofotometriás méréseink alapján a HSA molekula négy ligandumot képes megkötni. Az oldatban kialakult HSADT726 komplexek látszólagos stabilitási állandója hasonló nagyságrendü, mint az irodalomban található antibiotikum-HSA kötés stabilitását jellemző lg $\beta$-értékek.

Rákellenes hatású $\mathrm{Ru}(\mathrm{II})-\mathrm{komplexek}$ oldategyensúlyának vizsgálata során $\left[\mathrm{Ru}(\mathrm{II})-\eta^{6}-p\right.$ cimol] komplexképző tulajdonságát vizsgáltuk $(\mathrm{O}, \mathrm{O})$ donoratomokat tartalmazó hidroxipiron (allomaltol és etil-maltol), (O,N) donoratomos pikolinsav, 6-metil-pikolinsav és 2,6dipikolinsav, illetve az tioallomaltol ligandumokkal, mely utóbbi kén és oxigén donoratomokkal rendelkezik. A [Ru(II)- $\eta^{6}-p$-cimol] molekulában a Ru(II) központi fémion egy cimol molekulával alakít ki kötést, így a molekulának három szabad koordinációs helye marad. Az ide kötődő ligandumok erősen befolyásolják a komplex stabilitását és a biológiai hatását is. Arra kerestük a választ, hogy van-e vajon összefüggés a kialakult komplexek stabilitása és rákos sejteken mért citotoxikus aktivitása között. A vizsgálati módszereink pH-potenciometriás, UV-látható spektrofotometriás és ${ }^{1} \mathrm{H} \quad \mathrm{NMR}$ spektroszkópiás mérések voltak. Vizsgálatokat végeztünk kloridion-mentes illetve kloridionokat tartalmazó vizes oldatban is, hogy információt nyerjünk arról, hogy a biológiai rendszerekben is fontos funkciót betöltő kloridion hogyan befolyásolja az oldategyensúlyi folyamatokat, és ezáltal a biológiai aktivitást.

Vizsgálataink során megállapítottuk, hogy $(\mathrm{O}, \mathrm{O})$ és $(\mathrm{O}, \mathrm{N})$ ligandumok esetében savas kémhatású oldatban [ML] komplexek képződnek. Dipik esetében kis pH-értékeknél $[\mathrm{MLH}]$ komplex is megjelenik, ez azonban már igen kis pH-értéken deprotonálódik (pK $[\mathrm{MLH}]=1,15)$. A kialakult $[\mathrm{ML}]$ komplexek pK 8-9,5 értékkel protont veszítenek. A deprotonálódás során a harmadik koordinációs helyen lévő vízmolekula deprotonálódik. $(\mathrm{O}, \mathrm{O})$ donoratomos ligandumok komplexeinek deprotonálódásával párhuzamosan megkezdődik a komplex disszociációja is, és $\left[\mathrm{M}_{2} \mathrm{H}_{-3}\right]$ három hidroxido-hidas dimer alakul ki. 
Ez a folyamat lassú, a vizsgálat időtartama alatt a rendszerben az egyensúly nem állt be, így a rendszerinket $\mathrm{pH} \sim 9$-ig értékeltük ki. A [Ru(II)- $\eta^{6}-p$-cimol] hidrolízisét leíró állandók alapján a disszociációnak és $\mathrm{M}_{2} \mathrm{H}_{3}$ képződésének $(\mathrm{O}, \mathrm{N})$ ligandumok komplexeinél is le kellene játszódnia, azonban ennek jelét az ${ }^{1} \mathrm{H}$ NMR spektrumokon lúgos közegben 24 óra után sem láttuk. A Ru(II)-arén komplexek lassú disszociációs folyamatai az irodalomban is ismertek, kinetikai okuk részben az irodalomban tárgyalt. Az $(\mathrm{O}, \mathrm{O})$ ligandumok komplexek kisebb stabilitású komplexet képzenek a [Ru(II)- $\eta^{6}-p$-cimol]-lal, mint az $(\mathrm{O}, \mathrm{N})$ koordinációjú pikolinsav származékok, azonban a legnagyobb biológiai aktivitással rendelkező $(\mathrm{O}, \mathrm{S})$ donoratomos ligandumok komplexeinek stabilitása több nagyságrenddel haladja meg az $(\mathrm{O}, \mathrm{O})$ és $(\mathrm{O}, \mathrm{N})$ ligandumokét. A tioszármazékok esetében a komplexképződés már nagyon kis pH-n $100 \%$-os. A komplexek stabilitása olyan nagy, hogy pH-t 0,8-ra csökkentve sem tudtuk az [ML] komplex disszociációját elérni, stabilitási állandóját csak egy kellően nagy minimum értéket tudtunk becsülni. 1:1 fémion-ligandum arány mellett pH 6 felett feltételezéseink szerint elindul az [ML] komplex hidrolízise, ami vízben rosszul oldódó oligomer vagy polimer részecskék kialakulásához vezet. Tioallomaltol ligandum felesleg jelenlétében az $(\mathrm{O}, \mathrm{O})$ és $(\mathrm{O}, \mathrm{N})$ ligandumoktól eltérően biszkomplex képződését mutattuk ki, melyet ${ }^{1} \mathrm{H}$ NMR mérésekkel bizonyítottunk. Megállapítottuk, hogy a képződő biszkomplexben az egyik ligandum kétfogúként, a második pedig egyfogúként kén donoratomján keresztül koordinálódik a központi fémionhoz. Savas közegben az egyfogúként koordinálódó ligandum hidroxilcsoportja protonálódni képes $\left(\mathrm{pK}\left[\mathrm{ML}_{2} \mathrm{H}\right]=\right.$ 5,73). A hasonló szerkezetü tiomaltol esetében kimutatták, hogy kellően magas ligandumfelesleg mellett triszkomplex is képződik, azonban tioallomaltol esetében a triszkomplex képződését nem tudtuk bizonyítani.

Megállapítottuk, hogy kloridion jelenlétében az oldatban jelenlévő klorid a $\left[\mathrm{Ru}(\mathrm{II})-\eta^{6}\right.$ p-cimol]-hoz való koordinálódása révén visszaszorítja valamelyest annak a kétfogú ligandummal való komplexképződését. A kloro/akva cserét részletesen is vizsgáltuk, a kloridion koncentrációt változtatva mértük a komplexek oldatainak ${ }^{1} \mathrm{H}$ NMR spektrumát, és becsültük meg a $\left[\mathrm{ML}\left(\mathrm{H}_{2} \mathrm{O}\right)\right]^{+}+\mathrm{Cl}^{-} \rightleftharpoons[\mathrm{MLCl}]+\mathrm{H}_{2} \mathrm{O}$ folyamat egyensúlyi állandóját. Az így nyert állandók alapján számolni lehet az akva/kloridokomplexek arányát különböző kloridion koncentrációjú oldatokban, amelynek a komplex stabilitásán túl igen fontos jelentősége lehet a biológiai hatás kialakulásában. A vérhez képest a sejtplazmában a kloridkoncentráció kisebb, és a sejt belsejében a klorid ligandum vízmolekulára cserélődik, ami valószínűleg fontos aktivációs lépés lehet a komplexek hatásmechanizmusában. 
A komplexek stabilitását összevetve a biológiai aktivitással, megállapítható, hogy a kialakult komplex stabilitása és rákos sejtekre való citotoxikus aktivitása között összefüggés van. A legkisebb stabilitású $(\mathrm{O}, \mathrm{O})$ ligandumok komplexeinek $\mathrm{IC}_{50}$ értéke a legmagasabb, ami alacsony toxicitásra utal. A [Ru(II)- $\eta^{6}-p$-cimol]-pikolinsav komplexének mind stabilitása, mind citotoxicitása meghaladja a hidroxi-piron származékokét. A dipik-komplex stabilitása nagyobb, mint a pikolinsavé, azonban toxicitása nagyon alacsony. A biológiai aktivitás hiánya valószínüleg az, hogy már $0,1 \mathrm{M}$ kloridion koncentráció mellett is az akvakomplex aránya nagyon magas ( 35\%). Másik oka lehet a rákellenes aktivitás hiányának a dipikolinsav [ML] kloridokomplexének negatív töltése, mely valószínűleg akadályozza a komplex átjutását a rákos sejtek membránjain. Az $(\mathrm{O}, \mathrm{S})$ ligandumok komplexeinek kiemelkedő toxicitása összefüggésben lehet a komplexeik nagy stabilitásával.

Spektrofluorimetriásan vizsgáltuk a [Ru(II)- $\eta^{6}-p$-cimol], a [Ru(II)- $\eta^{6}-p$-cimol]-pikolinsav és $\left[\mathrm{Ru}(\mathrm{II})-\eta^{6}-p\right.$-cimol]-etil-maltol kölcsönhatását humán szérum albuminnal az I. kötőhelyen. Megállapítottuk, hogy a pikolinsav jelenléte jelentősen gátolja a $\left[\mathrm{Ru}(\mathrm{II})-\eta^{6}-p\right.$ cimol] transzportfehérjén való megkötődését. A [Ru(II)- $\eta^{6}-p$-cimol] HSA-hoz való kötődése lassú folyamat, az egyensúly 2 óra alatt nem alakul ki az oldatban. [Ru(II)- $\eta^{6}-p$-cimol]etil-maltol komplex esetében ezt az időfüggést nem tapasztaltuk. Mivel a 24 órás, különböző HSA-komplex arány mellett felvett görbék lefutása [Ru(II)- $\eta^{6}-p$-cimol] és $\left[\mathrm{Ru}(\mathrm{II})-\eta^{6}-p\right.$-cimol]-etil-maltolát komplex esetében megegyezik, arra következtetünk, hogy az etil-maltol megkönnyíti a [Ru(II)- $\eta^{6}-p$-cimol]-HSA kötés kialakulását. Valószínűleg a kis stabilitású komplexből a HSA könnyen kiszorítja a koordinálódó etil-maltolt, míg az etil-maltol mentes oldatban a $\left[\mathrm{Ru}(\mathrm{II})-\eta^{6}-p\right.$-cimol $]\left[\mathrm{M}_{2} \mathrm{H}_{-3}\right]$ formában van jelen, amelynek disszociációja és HSA-hoz való kötődése hosszabb időt igényel. 


\section{Summary \\ SOLUTION EQUILIBRIUM CHEMISTRY OF LIGANDS AND METAL COMPLEXES AS POSSIBLE THERAPEUTIC AGENTS IN CANCER AND ALZHEIMER'S DISEASES}

The present Ph.D. theses consists of two connecting research projects focusing on the development of novel therapeutic agents for two serious and often incurable diseases: cancer and Alzheimer's disease. For neurodegenerative disorders the metal ion dyshomeostasis is assumed to be involved in the development of the disease, which can be corrected by using suitable chelators. In case of anticancer therapeutics the metalcontaining complexes can be cytotoxic on the cancer cells.

The aim of our work in cooperation with University of Padova is to develop new potential metal chelating agents, which are able to compete against the $\beta$-amyloid peptides for the metal ions, preventing the formation of toxic oligomers of $\beta$-amyloids and then aggregation as plaque deposits in Alzheimer's brain. Chelating ligands (like deferiprone, deferrioxamine, D-penicillamine) are presently used in the removal of the excess of metals like $\mathrm{Al}(\mathrm{III}), \mathrm{Fe}(\mathrm{III})$ and $\mathrm{Cu}(\mathrm{II})$, however they have a number of drawbacks. The studied ligands were hydroxy-pyridine carboxylic acid derivatives which are cytotoxic up to $1 \mathrm{mM}$ and with appropriate substituents may be able to remove the $\mathrm{Fe}$ (III), $\mathrm{Al}(\mathrm{III})$ and $\mathrm{Cu}$ (II) from $\beta$-amyloid aggregates without taking the essential metal ions from biomolecules and disturbing their normal functions.

Solution equilibria of the possible chelator compounds with $\mathrm{Al}(\mathrm{III})$ and $\mathrm{Fe}(\mathrm{III})$ were studied in the University of Padova. The interactions of the ligands with $\mathrm{Cu}(\mathrm{II}), \mathrm{Zn}(\mathrm{II})$ and human serum albumin (HSA) were investigated in Szeged.

The hydroxy-pyridine carboxylic acids form mono, bis and tris complexes with $\mathrm{Al}(\mathrm{III})$ and Fe(III). The stability of the complexes was not high enough to prevent the hydrolysis of Fe(III) in most cases, only four studied ligands (DT1, DT712, DQ716 and DQ715 (studied by me)) were able to keep the Fe(III) dissolved in the physiological $\mathrm{pH}$ range. However, the $\mathrm{Al}(\mathrm{III})$ binding ability of these ligands is reasonable - all ligands can prevent the formation of $\mathrm{Al}(\mathrm{OH})_{3}$ - but unfortunately not so efficiently as deferiprone or deferrioxamine. The coordination strength is significantly increased when methyl substituents are present in positions 5 or 6 at the pyridine ring. 
Due to the hard character of the donor atoms of these studied ligands the complex stability is lower with the borderline $\mathrm{Zn}$ (II) and $\mathrm{Cu}$ (II) ions than that of $\mathrm{Fe}$ (III) and $\mathrm{Al}(\mathrm{III})$. The stability constants of the formed $\mathrm{Zn}$ (II) and $\mathrm{Cu}$ (II) complexes were determined primarily by $\mathrm{pH}$-potentiometry and in case of DQ5 and DQ715 and the results were confirmed by the combined approach of UV-Vis spectrophotometric and EPR or ${ }^{1} \mathrm{H}$ NMR spectroscopic measurements.

On basis of the overall stability constants, the $K_{\mathrm{D}}$ dissociation constants have been calculated for the complexes at $\mathrm{pH}$ 7.4. It has been found that among the studied ligands only the DQ716 can form sufficiently high stability complexes with $\mathrm{Cu}$ (II) and can retrieve the $\mathrm{Cu}(\mathrm{II})$ from the $\beta$-amyloid-aggregates and prevent the oligomerisation and aggregation processes. The order of magnitude of the $K_{\mathrm{D}}$ value of the $\mathrm{Zn}$ (II) complexes falls in the range of $\mathrm{mmol} / \mathrm{dm}^{3}$, which means that $\mathrm{Zn}$ (II) binding ability of both ligands is very low. Therefore these ligands most probably do not affect the zinc homeostasis in vivo.

Interactions of some chosen ligands with human serum albumin (HSA) were studied by ultrafiltration/UV-Vis and fluorescence spectroscopy. DQ ligands do not exhibit a measurable tendency to interact with HSA. Only ligand DT726 - one of 3-hydroxy-4pyridinecarboxylic derivatives is able to bind to the albumin. From our measurements, we could conclude that up to four DT726 molecules bind to HSA with high affinity at pH 7.40 .

Transition metal complexes play a crucial role in antitumor therapy. In the last decade, numerous organometallic ruthenium(II)- $\eta^{6}$-arene complexes mainly with piano-stool structure were synthesized and tested by in vitro assays regarding their bioactivity. In these $\mathrm{Ru}(\mathrm{II})$ complexes the facial arene moiety results in the protection of the metal centre against oxidation. This half-sandwich complex has three available coordination sites to interact with different ligands. The type of the chelating ligands has a distinct influence on the stability of the complex formed and the ligand can prevent the hydrolysis of Ru(II)- $\eta^{6}$ $p$-cymene organometallic fragment. A large number of $\left[\left(\mathrm{Ru}(\mathrm{II})-\eta^{6}-p\right.\right.$-cymene $\left.)(\mathrm{XY}) \mathrm{Cl}\right]$ type compounds was prepared, where $\mathrm{XY}$ is an $(\mathrm{O}, \mathrm{O}),(\mathrm{O}, \mathrm{S}),(\mathrm{O}, \mathrm{N}),(\mathrm{N}, \mathrm{N})$ or $(\mathrm{N}, \mathrm{S})$ bidentate ligand.

Complexes of hydroxypyrones (such as the well-known 3-hydroxy-2-methyl-4H-pyran4-one (maltol)) show only moderate cytotoxicity on various cancer cell lines as compared with the more active $(\mathrm{O}, \mathrm{S})$ type complexes of hydroxythiopyrones. In order to establish structure-stability-activity relationships the characterization of the stability of these 
complexes, the knowledge of the speciation and the most plausible chemical forms in aqueous solution is mandatory. Therefore, in the second part of this work we performed detailed $\mathrm{pH}$-potentiometric, UV-Vis spectrophotometric and ${ }^{1} \mathrm{H}$ NMR spectroscopic measurements to investigate the stoichiometry and stability of the $\left[\mathrm{Ru}(\mathrm{II})-\eta^{6}-p\right.$-cymene] complexes of hydroxypyrone (ethyl maltol, allomaltol), picolinic acid (pik), its 6-methyl (6-Mepik) and 6-carboxylate (dipik) derivatives and thioallomaltol ligands. The chlorido/aqua co-ligand exchange reaction in the $\left[\left(\mathrm{Ru}(\mathrm{II})-\eta^{6}-p\right.\right.$-cymene $\left.)(\mathrm{L})(\mathrm{Cl})\right]$ species was also monitored. Overall stability constants of the complexes were determined in the presence and in the absence of chloride ions.

$(\mathrm{O}, \mathrm{O})$ and $(\mathrm{O}, \mathrm{N})$ ligands form exclusively mono $[\mathrm{ML}]$ (and $[\mathrm{MLH}]$ in the case of dipik at $\mathrm{pH}<2$ ) complexes in which the ligands coordinate in a bidentate fashion. Hydrolysis of these complexes results in the formation of the mixed-hydroxido species $\left[\mathrm{Ru}(\mathrm{II})-\eta^{6}-p\right.$ cymene $)(\mathrm{L})(\mathrm{OH})]$ by the deprotonation of the coordinated water molecule in the basic $\mathrm{pH}$ range, although this process is almost negligible at physiological $\mathrm{pH}$. However, in case of $(\mathrm{O}, \mathrm{O})$ ligands decomposition of the complex with a slow reaction rate was also found in the same $\mathrm{pH}$ range leading to the formation of the dinuclear trihydroxido-bridged species $\left[\mathrm{Ru}_{2}\left(\eta^{6}-p \text {-cymene }\right)_{2}(\mathrm{OH})_{3}\right]^{+}$. The partial decomposition of the complexes $[\mathrm{ML}]^{+}$and $\left[\mathrm{MLH}_{-1}\right]$ formed in the $\left[\mathrm{Ru}(\mathrm{II})-\eta^{6}-p\right.$-cymene]-(O,N) systems would be expected at high $\mathrm{pH}$ values, although the ${ }^{1} \mathrm{H}$ NMR spectra clearly show the lack of the formation of $\left[\operatorname{Ru}_{2}\left(\eta^{6}-p-\right.\right.$ cymene $\left.)_{2}(\mathrm{OH})_{3}\right]^{+}$or the non-bound ligand in the basic $\mathrm{pH}$ range even after $24 \mathrm{~h}$ waiting. The slow dissociation of the complex $[\mathrm{ML}]^{+}$has presumably kinetic reason. Similarly slow decomposition processes were observed for the complexes of hydroxypyridones. Comparing the stabilities of $\mathrm{Ru}(\mathrm{II})-\eta^{6}-p$-cymene [ML] complexes the following stability trend is seen: $(\mathrm{O}, \mathrm{S})>(\mathrm{O}, \mathrm{N})>(\mathrm{O}, \mathrm{O})$.

In case of thioallomaltol the $\mathrm{O} / \mathrm{S}$ exchange results in significant impact on the complex stabilities. The complex formation is completed at $\mathrm{pH}<2$ and results of the UV-Vis titrations show no signs of complex decomposition at $\mathrm{pH}<1$. Because of the high stabilities only a threshold limit could be estimated for the $\log \beta$ of complex [ML]. The hydrolysis of the thioallomaltol complex at $\mathrm{pH}>6$ was found to be more complicated most probably due to the formation of mixed hydroxido oligomers with limited water solubility. At excess of ligand bis-ligand complexes were found to be formed with thioallomaltol in which one of the ligands coordinates via the usual $(\mathrm{O}, \mathrm{S})$ bidentate mode and the other one binds in a monodentate fashion through the thione-sulfur. The $\left[\mathrm{ML}_{2} \mathrm{H}\right]$ type bis-complex 
predominates at the acidic $\mathrm{pH}$ range with protonated phenolic-OH. Chloride ions are coordinative ligands for ruthenium(II) in aqueous solution. The aquation of the $\left[\mathrm{Ru}(\mathrm{II})-\eta^{6}-\right.$ p-cymene $(\mathrm{L})(\mathrm{Cl})]$ has a strong impact on the bioactivity, therefore the $\mathrm{Cl}^{-} / \mathrm{H}_{2} \mathrm{O}$ co-ligand exchange process was also studied by ${ }^{1} \mathrm{H}$ NMR spectroscopy. The spectral changes of the $\left[\left(\mathrm{Ru}(\mathrm{II})-\eta^{6}-p \text {-cymene }\right)(\mathrm{L})\left(\mathrm{H}_{2} \mathrm{O}\right)\right]^{+}$were followed at various chloride concentrations at constant $\mathrm{pH}$ at which the metal complex predominates. Based on the changes of chemical shifts or the integrated areas of the corresponding peaks could be calculated and converted to molar fractions, and the stepwise stability constants could be estimated for the following equilibrium:

$$
\left[\left(\mathrm{Ru}(\mathrm{II})-\eta^{6}-p \text {-cymene }\right)(\mathrm{L})\left(\mathrm{H}_{2} \mathrm{O}\right)\right]+\mathrm{Cl}^{-} \rightleftharpoons\left[\left(\mathrm{Ru}(\mathrm{II})-\eta^{6}-p \text {-cymene }\right)(\mathrm{L})(\mathrm{Cl})\right]+\mathrm{H}_{2} \mathrm{O}
$$

Based on these equilibrium constants $\left(\log \mathrm{K}^{*}\right)$ the ratio of chlorido/aqua complex can be calculated for the complexes [ML] at various chloride concentrations.

Comparing the stabilities of $\left[\left(\mathrm{Ru}(\mathrm{II})-\eta^{6}-p\right.\right.$-cymene $\left.)\right]$ complexes formed the stability trend corresponds well to the order of their biological activity. Complexes of hydroxypyrones with lower stability show only moderate cytotoxicity on various cancer cell lines. The $\left[\mathrm{Ru}(\mathrm{II})-\eta^{6}-p\right.$-cymene] binding ability of the picolinate ligands represents the following order: 6-Mepik < pik < dipik. The increased stability of the complex of pik compared to that of the $(\mathrm{O}, \mathrm{O})$ donor hydroxypyrones may be related to its higher biological activity. The complex of dipik possesses $c a$. one order of magnitude lower $\log \mathrm{K}^{*}$ value than pik resulting in less favourable formation of the chlorido [(Ru(II)- $\eta^{6}-p$ cymene $)(\mathrm{L})(\mathrm{Cl})]$ complex. The coordination of the negatively charged chloride ions to the neutral $\left[\left(\mathrm{Ru}(\mathrm{II})-\eta^{6}-p\right.\right.$-cymene $\left.)(\mathrm{L})\left(\mathrm{H}_{2} \mathrm{O}\right)\right]$ of dipik with the non-coordinated $\mathrm{COO}^{-}$moiety seems to be less pronounced than to the positively charged aqua complex of pik and 6Mepik. This finding may contribute to the explanation of the lower biological activity of complex dipik compared with that of pik. The readiness of the dipik complex for the aquation may lead to an easier interaction with blood serum components via replacing the coordinated water molecule, while the neutral complex $\left[\left(\mathrm{Ru}(\mathrm{II})-\eta^{6}-p\right.\right.$-cymene $\left.)(\mathrm{L})(\mathrm{Cl})\right]$ of pik can remain more intact during the transport processes facilitating its absorption across the cancer cell membranes. The hydroxythiopyr(id)one ligands form complexes of significantly higher stability compared with the hydroxypyrones correlated with their biologically more active cytotoxicity.

Fluorescence measurements were also performed on the binding properties of $[\mathrm{Ru}(\mathrm{II})-$ $\eta^{6}$-p-cymene $], \quad$ a $\quad\left[\mathrm{Ru}(\mathrm{II})-\eta^{6}-p\right.$-cymene $]$-picolinate $\quad$ and $\quad\left[\mathrm{Ru}(\mathrm{II})-\eta^{6}-p\right.$-cymene $]$-ethyl 
maltolate towards HSA to the drug binding site I. The fluorescence data indicate the presence of pik with strong binding ability to the $\left[R u(I I)-\eta^{6}-p\right.$-cymene] hinders the formation of $\left[\mathrm{Ru}(\mathrm{II})-\eta^{6}-p\right.$-cymene]-protein adduct. The binding of $\left[\mathrm{Ru}(\mathrm{II})-\eta^{6}-p\right.$-cymene] (without ligands) to HSA is a slow process, and the equilibrium is not complete after 2 hours incubation time, while in case of the ethyl maltolato complex the interaction is rather fast. After $24 \mathrm{~h}$ incubation the effect of increasing concentration of [Ru(II)- $\eta^{6}-p$-cymene] and its ethyl-maltolato complex on the protein fluorescence, namely the quenching of the fluorescence emission intensity is quite similar. We have concluded that the coordination of ethyl maltol facilitates the formation of the $\left[\mathrm{Ru}(\mathrm{II})-\eta^{6}-p\right.$-cymene]-albumin adduct. Probably the HSA can displace the ethyl maltol with moderate binding from the complex, while without ligand the $\left[\mathrm{Ru}(\mathrm{II})-\eta^{6}-p\right.$-cymene] exists in the form $\left[\mathrm{M}_{2} \mathrm{H}_{-3}\right]$, and as its dissociation process is slow the formation of the $\left[\mathrm{Ru}(\mathrm{II})-\eta^{6}-p\right.$-cymene]-albumin adduct needs more time. 


\section{Mellékletek}

\section{M1-a}

Etil-maltol, allomaltol, pik, 6-Mepik, dipik és tioallomaltol ligandumok ${ }^{1} \mathrm{H}$ NMR spektroszkópiával meghatározott $\mathrm{pK}$ értékei, [HL] és $[\mathrm{L}]$ formáinak kémiai eltolódás értékei $(\mathrm{ppm})\left(\mathrm{t}=25,0{ }^{\circ} \mathrm{C} ; \mathrm{I}=0,20 \mathrm{M}\right.$

\begin{tabular}{lllcccc}
\multicolumn{6}{l}{$\left.(\mathrm{KCl}) ; 10 \%(\mathrm{v} / \mathrm{v}) \mathrm{D}_{2} \mathrm{O} / \mathrm{H}_{2} \mathrm{O}\right)^{\mathrm{a}}$} \\
\hline $\mathbf{p} \boldsymbol{K}_{\mathbf{a}}$ & etil-maltol & allomaltol & pik & 6-Mepik & dipik & tioallomaltol \\
\hline $\mathbf{H L}$ & $8,58(1)$ & $7,97(1)$ & $5,16(1)$ & $5,91(1)$ & $4,55(1)$ & $7,61(1)$ \\
$\mathbf{H} \mathbf{L}$ & & & & & $2,04(7)$ & \\
\hline $\mathbf{H L}$ & $\mathrm{CH}_{3}(\mathrm{t}): 1,17$ & $\mathrm{CH}_{3}(\mathrm{~s}): 2,30$ & $\mathrm{CH}(3)(\mathrm{d}): 8,43$ & $\mathrm{CH}(3)(\mathrm{d}): 7,93$ & $\mathrm{CH}(3)(\mathrm{d}): 8,65$ & $\mathrm{CH}_{3}(\mathrm{~s}): 2,28$ \\
& $\mathrm{CH}_{2}(\mathrm{q}): 2,73$ & $\mathrm{CH}(3)(\mathrm{s}): 6,37$ & $\mathrm{CH}(4)(\mathrm{t}): 8,15$ & $\mathrm{CH}(4)(\mathrm{t}): 8,49$ & $\mathrm{CH}(4)(\mathrm{t}): 8,43$ & $\mathrm{CH}(3)(\mathrm{s}): 7,31$ \\
& $\mathrm{CH}(5)(\mathrm{d}): 6,48$ & $\mathrm{CH}(6)(\mathrm{s}): 8,00$ & $\mathrm{CH}(5)(\mathrm{t}): 8,69$ & $\mathrm{CH}(5)(\mathrm{d}): 8,20$ & & $\mathrm{CH}(6)(\mathrm{s}): 8,00$ \\
& $\mathrm{CH}(6)(\mathrm{d}): 7,99$ & & $\mathrm{CH}(6)(\mathrm{d}): 8,77$ & $\mathrm{CH}(6)(\mathrm{s}): 2,83$ & & \\
$\mathbf{L}$ & $\mathrm{CH}_{3}(\mathrm{t}): 1,12$ & $\mathrm{CH}(\mathrm{s}): 2,23$ & $\mathrm{CH}(3)(\mathrm{d}): 7,90$ & $\mathrm{CH}(3)(\mathrm{d}): 7,38$ & $\mathrm{CH}(3)(\mathrm{d}): 7,99$ & $\mathrm{CH}_{3}(\mathrm{~s}): 2,22$ \\
& $\mathrm{CH}_{2}(\mathrm{q}): 2,68$ & $\mathrm{CH}(3)(\mathrm{s}): 6,23$ & $\mathrm{CH}(4)(\mathrm{t}): 7,53$ & $\mathrm{CH}(4)(\mathrm{t}): 7,80$ & $\mathrm{CH}(4)(\mathrm{t}): 7,99$ & $\mathrm{CH}(3)(\mathrm{s}): 7,25$ \\
& $\mathrm{CH}(5)(\mathrm{d}): 6,33$ & $\mathrm{CH}(6)(\mathrm{s}): 7,62$ & $\mathrm{CH}(5)(\mathrm{t}): 7,95$ & $\mathrm{CH}(5)(\mathrm{d}): 7,68$ & & $\mathrm{CH}(6)(\mathrm{s}): 7,55$
\end{tabular}

${ }^{\mathrm{a}} \mathrm{A}$ zárójelben az állandókra számolt utolsó jegy bizonytalansága van feltüntetve.

\section{M1-b.}

Etil-maltol, allomaltol, pik, 6-Mepik, dipik és tioallomaltol ligandumok [HL] és [L]- formájának moláris abszorbancia értékei $\left(\mathrm{t}=25,0^{\circ} \mathrm{C} ; \mathrm{I}=0,20 \mathrm{M}(\mathrm{KCl})^{\mathrm{a}}\right.$

\begin{tabular}{lccc}
\hline & $\mathbf{p K}$ & $\boldsymbol{\varepsilon}_{\text {max }}[\mathrm{HL}]$ & $\boldsymbol{\varepsilon}_{\max }[\mathbf{L}]$ \\
\hline etil-maltol & $8,56(1)$ & $7260 \mathrm{M}^{-1} \times \mathrm{cm}^{-1}(\lambda=276 \mathrm{~nm})$ & $6852 \mathrm{M}^{-1} \times \mathrm{cm}^{-1}(\lambda=322 \mathrm{~nm})$ \\
\hline allomaltol & $7,93(2)$ & $5777 \mathrm{M}^{-1} \times \mathrm{cm}^{-1}(\lambda=266 \mathrm{~nm})$ & $8886 \mathrm{M}^{-1} \times \mathrm{cm}^{-1}(\lambda=308 \mathrm{~nm})$ \\
\hline pik & $5,14(1)$ & $8610 \mathrm{M}^{-1} \times \mathrm{cm}^{-1}(\lambda=264 \mathrm{~nm})$ & $4906 \mathrm{M}^{-1} \times \mathrm{cm}^{-1}(\lambda=264 \mathrm{~nm})$ \\
\hline 6-Mepik & $5,86(1)$ & $6956 \mathrm{M}^{-1} \times \mathrm{cm}^{-1}(\lambda=274 \mathrm{~nm})$ & $4120 \mathrm{M}^{-1} \times \mathrm{cm}^{-1}(\lambda=272 \mathrm{~nm})$ \\
\hline dipik & $4,54(2)$ & $6580 \mathrm{M}^{-1} \times \mathrm{cm}^{-1}(\lambda=274 \mathrm{~nm})$ & $4098 \mathrm{M}^{-1} \times \mathrm{cm}^{-1}(\lambda=270 \mathrm{~nm})$ \\
\hline \multirow{2}{*}{ tioallomaltol } & $7,61(1)$ & $20680 \mathrm{M}^{-1} \times \mathrm{cm}^{-1}(\lambda=332 \mathrm{~nm})$ & $7552 \mathrm{M}^{-1} \times \mathrm{cm}^{-1}(\lambda=312 \mathrm{~nm})$ \\
& & & $16929 \mathrm{M}^{-1} \times \mathrm{cm}^{-1}(\lambda=380 \mathrm{~nm})$
\end{tabular}

a A zárójelben az állandókra számolt utolsó jegy bizonytalansága van feltüntetve. 
A Padovai Egyetemen előállított és vizsgált hidroxi-piridinkarbonsav molekulák

4-hidroxi-2-metil-3-piridinkarbonsav

M3

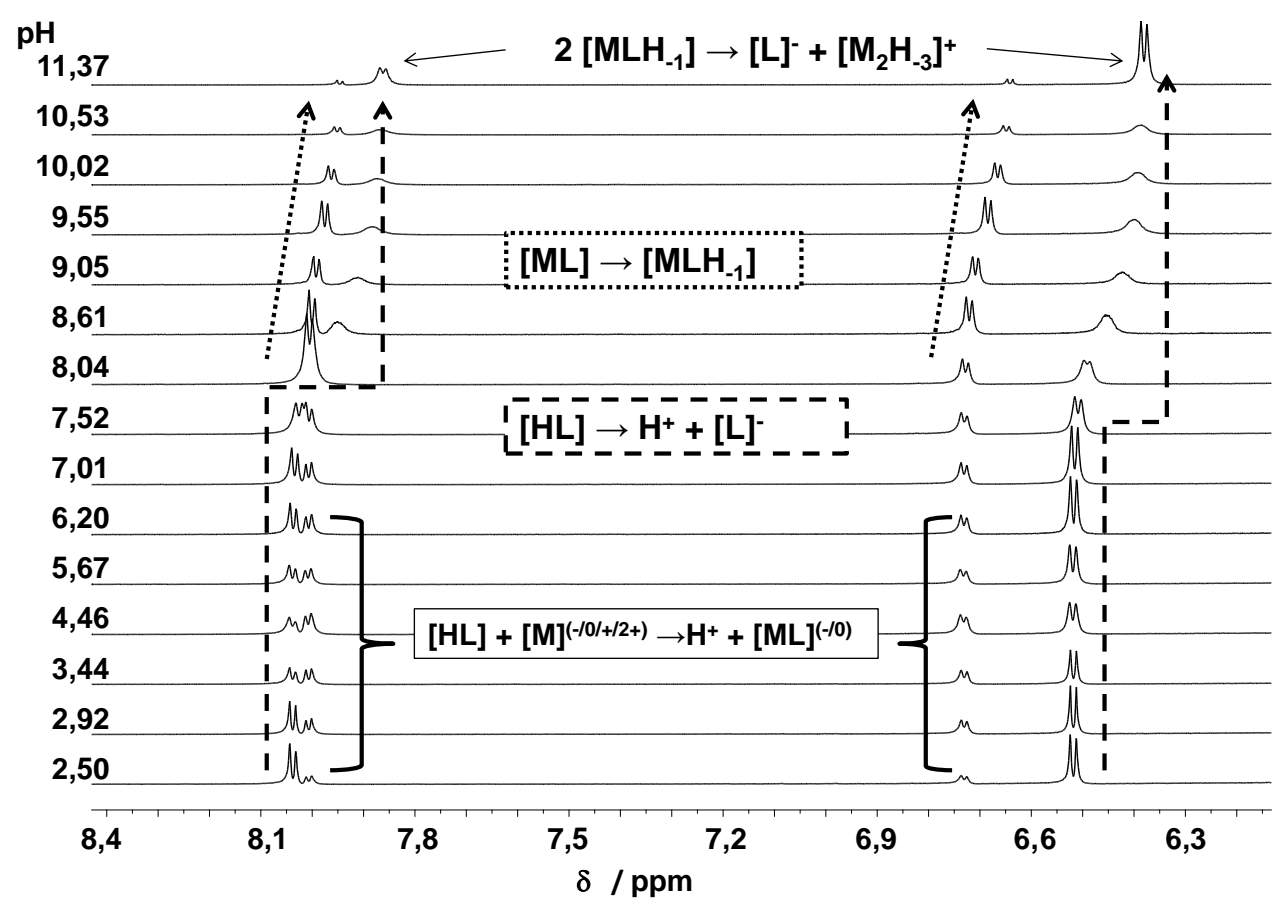

[Ru(II)- $\eta^{6}-p$-cimol]-etil-maltol1:2 fémion-ligandum arányú rendszer $\mathrm{pH}$-függő ${ }^{1} \mathrm{H}$ NMR spektrumai a ligandum aromás protonjaihoz tartozó jelek kémiai eltolódásnak tartományában.

(A jelek $\sim 8,1-7,8$ ppm tartományban a ligandum $\mathrm{CH}(6)$ protonjához, $\sim 6,8-6,3$ ppm tartományban a ligandum $\mathrm{CH}(5)$ protonjaihoz rendelhetök.) 


\section{Felhasznált irodalom}

${ }^{1}$ C.P. Ferri, M.Prince, C. Brayne, H. Brodaty, L. Fratiglioni, M. Ganguli, K. Hall, K. Hasegawa, H. Hendrie, Y. Huang, A. Jorm, C. Mathers, P.R. Menezes, E. Rimmer, M. Scazufca, Alzheimer's Disease International. Global prevalence of dementia: a Delphi consensus study, Lancet, (2005) 366, 2112-2117

${ }^{2}$ P. Tariska, Alzheimer-kór, Golden Book Kiadó, Budapest, (2000)

${ }^{3}$ P.T. Francis, A.M. Palmer, M. Snape, G.K. Wilcock, J Neurol Neurosurg Psychiatry, (1999) 66, 137-147

${ }^{4}$ Z.X. Shen, Med Hypotheses, (2004) 63, 308-321

${ }^{5}$ B. Su, X. Wang, A. Nunomura, P.I. Moreira, H. Lee, G. Perry, M.A. Smith, X. Zhu, Curr Alzheimer Res, (2008) 5, 525-532

${ }^{6}$ A. Hofman, A. Ott, M.M. Breteler, M.L. Bots, A.J. Slooter, F. van Harskamp, C.N. van Duijn, C. Van Broeckhoven, D.E. Grobbee, Lancet, (1997) 349,151-154

${ }^{7}$ I.L. Notkola, R. Sulkava, J. Pekkanen, T. Erkinjuntti, C. Ehnholm, P. Kivinen, J. Tuomilehto, A.Nissinen, Neuroepidemiology, (1998) 17, 14-20

${ }^{8}$ G.L. Wenk, J Clin Psychiatry, (2003) 64, 7-10

${ }^{9}$ D.J. Selkoe, Am J Psychiatry, (1997) 154, 1198

${ }^{10}$ D.J. Selkoe, Ann Intern Med, (2004) 140, 627-638

${ }^{11}$ D. Thirumalai, D.K. Klimov, R.I. Dima, Curr Opin Struct Biol, (2003) 13, 146-159

${ }^{12}$ L. Söderberg, C. Dahlqvist, H. Kakuyama, J. Thyberg, A. Ito, B. Winblad, J. Näslund, L.O. Tjernberg, FEBS J, (2005) 272, 2231-2236

${ }^{13}$ J.L. Cummings, $N$ Engl J Med, (2004) 351, 56-67

${ }^{14}$ M. Stefani, C. M. Dobson, J Mol Med, (2003) 81, 678-699

${ }^{15}$ G. Grasso, M.L. Giuffrida, E. Rizzarelli, Metallomics, (2012) 4, 937-949

${ }^{16}$ K. Garai, P. Sengupta, B. Sahoo, S. Maiti, Biochem Biophys Res Commun, (2006) 345, 210-215

${ }^{17}$ A. Tiiman, P. Palumaa, V. Tõugu, Neurochem Int, (2013) 62, 367-378

${ }^{18}$ C. Exley, Coord Chem Rev, (2012) 256, 2142-2146

${ }^{19}$ C.C. Curtain, F. Ali, I. Volitakis, R.A. Cherny, R.S. Norton, K. Beyreuther, C.J. Barrow, C.L. Masters, A.I. Bush, K.J. Barnham, J Biol Chem, (2001) 276, 20466-20473

${ }^{20}$ F.P. Guengerich, J Biol Chem, (2009) 284, 18557 -

${ }^{21}$ D.G. Smith, R. Cappai, K.J. Barnham, Biochim Biophys Acta, (2007) 1768, 1976-1990

22 K.J. Barnham, C.L. Masters, A.I. Bush, Nat Rev Drug Discovery, (2004) 3, 205-214

${ }^{23}$ M. Valko, D. Leibfritz, J. Moncol, M.T. Cronin, M. Mazur, J. Telser, Int J Biochem Cell Biol, (2007) 39, 44-84

${ }^{24}$ K.B. Beckman, B.N. Ames, J Biol Chem, (1997) 272, 19633-19636

${ }^{25}$ M. Dizdaroglu, Mutat Res, (1992) 275, 331-342

${ }^{26}$ L.J. Marnett, Mutat Res, (1999) 424, 83-95

${ }^{27}$ L.J. Marnett, Toxicology, (2002) 181, 219-222

${ }^{28}$ I. Dalle-Donne, A. Scaloni, D. Giustarini, E. Cavarra, G. Tell, G. Lungarella, R.

Colombo, R. Rossi, A. Milzani, Mass Spectrom Rev, (2005) 24, 55-99

${ }^{29}$ X. Huang, C.S. Atwood, M.A. Hartshorn, G. Multhaup, L.E. Goldstein, R.C. Scarpa, M.P. Cuajungco, D.N. Gray, J. Lim, R.D. Moir, R.E. Tanzi, A.I. Bush, Biochemistry, (1999) 38, 7609-7616 
${ }^{30}$ F.E. Ali, F. Separovic, C.J. Barrow, R.A. Cherny, F. Fraser, A.I. Bush, C.L. Masters, K.J. Barnham, J Pept Sci, (2005) 11, 353-360

${ }^{31}$ K.J. Barnham, G.D. Ciccotosto, A.K. Tickler, F.E. Ali, D.G. Smith, N.A. Williamson, Y.H. Lam, D. Carrington, D. Tew, G. Kocak, I. Volitakis, F. Separovic, C.J. Barrow, J.D. Wade, C.L. Masters, R.A. Cherny, C.C. Curtain, A.I. Bush, R. Cappai, J Biol Chem, (2003) 278, 42959-42965

${ }^{32}$ C. Exley, J Inorg Biochem, (2003), 97 1-7

${ }^{33}$ R.B. Martin, Metal ions in Biol Syst, (1988) 24, 1-57,

${ }^{34}$ J.C. Sherlock, in Aluminium in Food and the Environment, R. Massey eds, D. Taylor, Royal Society of Chemistry, London, (1988) 69

35 J.A.T. Pennington, J.W. Jones, in Aluminium and Health, ed.: H.J. Gitelman, Marcel Dekker, New York, (1989), 67

${ }^{36}$ S.L. Hem, J.L. White, in Aluminium and Health, ed.: H.J. Gitelman, Marcel Dekker, New York, (1989) 257

${ }^{37}$ R.B. Martin, Aluminium in chemistry biology and medicine eds. M. Nicolini, P.F. Zatta, B. Corain, Cortina International, Verona (1991)

${ }^{38}$ A.C. Alfrey, G.R. Legendre, W.D. Kaehny, New Eng J Med, (1976) 294, 184-188

${ }^{39}$ R.W. Shin, J Neurosci, (1994) 14, 7221-7233

${ }^{40}$ F. Ricchelli, Cell Mol Life Sci, (2005) 62, 1724-1733

${ }^{41}$ C. Exley, Free Radic Biol Med, (2004) 36, 380-387

${ }^{42}$ J.I. Mujika, F. Ruiperez, I. Infante, J.M. Ugalde, C. Exley, X. Lopez, J Phys Chem A, (2011) 115, 67176723

${ }^{43}$ P. Zatta, T. Kiss, M. Suwalsky, G. Berthon, Coord Chem Rev, (2002) 228, 271-284

${ }^{44}$ N. Tonder, F.F. Johansen, C.J. Frederickson, J. Zimmer, N.H. Diemer, Neurosci Lett, (1990) 109, 247-252

${ }^{45}$ G.A. Howell, M.G. Welch, C.J. Frederickson, Nature, (1984) 308, 736-738

${ }^{46}$ P.A. Adlard, J.M. Parncutt, D.I. Finkelstein, A.I. Bush, J Neurosci, (2010) 30, 1631-1636

${ }^{47}$ A.I. Bush, W.H. Pettingell, G. Multhaup, M. de Paradis, J.P. Vonsattel, J.F. Gusella, K. Beyreuther, C.L. Masters, R.E. Tanzi, Science, (1994) 265, 1464-1467

${ }^{48}$ Á.G. Hunya, Ph.D thesis, Physiological factors could enhance amyloid-beta toxicity, 2012

${ }^{49}$ M.P. Cuajungco, L.E. Goldstein, A. Nunomura, M.A. Smith, J.T. Lim, C.S. Atwood, X. Huang, Y.W. Farrag, G. Perry, A.I. Bush, J Biol Chem, (2000) 275, 19439-19442

${ }^{50}$ S.M. Cardoso, A.C. Rego, C. Pereira, C.R. Oliveira, Neurotox Res, (2005) 7, 273-282

${ }^{51}$ M.P. Cuajungco, G.J. Lees, NeuroReport, (1996) 7, 1301-1304

${ }^{52}$ G.J. Lees, A. Lehmann, M. Sandberg, A. Hamberger, Neurosci. Lett, (1990) 120, 155-158

${ }^{53}$ J.Y. Koh, D.W. Choi, Neuroscience, (1994) 60, 1049-1057

${ }^{54}$ C.P. Ferri, M. Prince, C. Brayne, H. Brodaty, L. Fratiglioni, M. Ganguli, K. Hall, K. Hasegawa, H. Hendrie, Y. Huang, A. Jorm, C. Mathers, P.R. Menezes, E. Rimmer, M. Scazufca, Lancet, (2005) 366, 2112 2117

${ }^{55}$ A. Kontush, U. Mann, S. Arlt, A. Ujeyl, C. Lührs, T. Müller-Thomsen, U. Beisiegel, Free Radic Biol Med, (2001) 31, 345-354

${ }^{56}$ J.C.S. Breitner, K.A. Welsh, M.J. Helms, P.C. Gaskell, B.A. Gau, A.D. Roses, M.A. Pericak-Vance, A.M. Saunders, Neurobiol Aging, (1995) 16, 523-530

${ }^{57}$ I. Ferrer, J Neurol Sci, (2010) 299, 139-149

${ }^{58}$ S.L. Rogers, M.R. Farlow, R.S. Doody, Neurology, (1998), 50, 136-145

${ }^{59}$ S.A. Lipton, NeuroRx, (2004), 1, 101-110 
${ }^{60}$ S. Ferris, R. Ihl, P. Robert, B. Winblad, G. Gatz, F. Tennigkeit, S. Gauthier, Alzheimers Dement, (2009) 5, 369-374

${ }^{61}$ K. Mullane, M. Williams, Biochem Pharmacol, (2013) 85, 289-305

${ }^{62}$ D. Galimberti, L. Ghezzi, E. Scarpini, J Neurol Sci, In Press, doi: 10.1016/j.jns.2012.12.013

${ }^{63}$ X.D. Huang, C.S. Atwood, R.D. Moir, M.A. Hartshorn, J.P. Vonsattel, R.E. Tanzi, A.I. Bush, J Biol Chem, (1997), 272, 26464-26470

${ }^{64}$ R.A. Cherny, J.T. Legg, C.A. McLean, D.P. Fairlie, X. Huang, C.S. Atwood, K. Beyreuther, R.E. Tanzi, C.L. Masters, A.I. Bush , J Biol Chem, (1999), 274, 23223-23228

${ }^{65}$ C.S. Atwood, G. Perry, H. Zeng, Y. Kato, W.D. Jones, K.Q. Ling, X.D. Huang, R.D. Moir, D.D. Wang, L.M. Sayre, M.A. Smith, S.G. Chen, A.I. Bush , Biochemistry, 43, (2004), 560-568

${ }^{66}$ J.M. Walshe, Lancet, (1982), 1, 643-647

${ }^{67}$ A.A. Qutub, C.A. Hunt, Brain Res Rev, (2005), 49, 595-617

${ }^{68}$ B. Gyurcsik, L. Nagy, Coord Chem Rev, (2000), 203, 81-149

${ }^{69}$ C. Fernández, O. Nieto, J.A. Fontenla, E. Rivas, M.L. de Ceballos, A. Fernández-Mayoralas, Org Biomol Chem, (2003), 1, 767-771

${ }^{70}$ G. Battaglia, M. La Russa, V. Bruno, L. Arenare, R. Ippolito, A. Copani, F. Bonina, F. Nicoletti, Brain Res, (2000), 860, 149-156

${ }^{71}$ E.J. Bilsky, R.D. Egleton, S.A. Mitchell, M.M. Palian, P. Davis, J.D. Huber, H. Jones, H.I. Yamamura, J. Janders, T.P. Davis, F. Porreca, V.J. Hruby, R. Polt, J Med Chem, (2000), 43, 2586-2590

72 A. Gaeta, F. Molina-Holgado, X.L. Kong, S. Salvage, S. Fakih, P.T. Francis, R.J. Williams, R.C. Hider, Bioorg Med Chem, (2011), 19, 1285-1297

${ }^{73}$ R.D. Abeysinghe, P.J. Roberts, C.E. Cooper, K.H. MacLean, R.C. Hider, J.B. Porter, J Biol Chem, (1996), 271, 7965-7972

${ }^{74}$ Z.D. Liu, R. Kayyali, R.C. Hider, J.B. Porter, A.E. Theobald , J Med Chem, (2002), 45 631-639

${ }^{75}$ L.E. Scott, M. Telpoukhovskaia, C. Rodríguez-Rodríguez, M. Merkel, M.L. Bowen, B.D.G. Page, D.E. Green, T. Storr, F. Thomas, D.D. Allen, P.R. Lockman, B.O. Patrick, M.J. Adam, C. Orvig, Chem Sci, (2011), 2, 642-648

${ }^{76}$ Y. Zhang, L.-Y. Chen, W.-X. Yin, J. Yin, S.-B. Zhang, C.-L. Liu, Dalton Trans, (2011), 40, 4830-4833

${ }^{77}$ J. Choi, J. Braymer, S. Park, S. Mustafa, J. Chae, M.H. Lim, Metallomics, (2011), 3, 284-291

${ }^{78}$ J.S. Choi, J.J. Braymer, R.P.R. Nanga, A. Ramamoorthy, M.H. Lim, Proc Natl Acad Sci USA, (2010), 107, 21990-21995

79 D. Bebbington, N.J.T. Monck, S. Gaur, A.M. Palmer, K. Benwell, V. Harvey, C.S. Malcolm, R.H.P. Porter, J Med Chem, (2000), 43, 2779-2782

${ }^{80}$ D. Bebbington, C.E. Dawson, S. Gaur, J. Spencer, Bioorg Med Chem Lett, (2002), 12, 3297-3300

${ }^{81}$ G. Liu, P. Men, P.L. Harris, R.K. Rolston, G. Perry, M.A. Smith, Neurosci Lett, (2006), 406, 189-193

${ }^{82}$ R.A. Cherny, C.S. Atwood, M.E. Xilinas, D.N. Gray, W.D. Jones, C.A. McLean, Neuron, (2001) 30, 665676

${ }^{83}$ H. Zheng, M.B.H. Youdim, L.M. Weiner, M. Fridkin, J Pept Res, (2005), 66, 190-203

${ }^{84}$ O. Ashur-Fabian, Y. Segal-Ruder, E. Skutelsky, D.E. Brenneman, R.A. Steingart, E. Giladi, I. Gozes, Peptides, (2003), 24, 1413-1423

${ }^{85}$ I. Gozes, I. Divinsky, I. Pilzer, M. Fridkin, D.E. Brenneman, A.D. Spier, J Mol Neurosci, (2003), 20, 315322

${ }^{86}$ R. Zaltzman, S.M. Beni, E. Giladi, A. Pinhasov, R.A. Steingart, J. Romano, E. Shohami, I. Gozes, Neuroreport, (2003), 14, 481-484 
${ }^{87}$ P.V. Kulkarni, C.A. Roney, P.P. Antich, F.J. Bonte, A.V. Raghu, T.M. Aminabhavi, Interdiscip Rev Nanomed Nanobiotechnol, (2010), 2, 35-47

${ }^{88}$ M.G. Dickens, K.J. Franz, Chembiochem, (2010), 11, 59-62

${ }^{89}$ L. Lannfelt, K. Blennow, H. Zetterberg, S. Batsman, D. Ames, J. Harrison, C.L. Masters, S. Targum, A.I. Bush, R. Murdoch, J. Wilson, C.W. Ritchie, Lancet Neurol, (2008), 7, 779-786

${ }^{90}$ N.G. Faux, C.W. Ritchie, A. Gunn, A. Rembach, A. Tsatsanis, J. Bedo, J. Harrison, L. Lannfelt, K. Blennow, H. Zetterberg, M. Ingelsson, C.L. Masters, R.E. Tanzi, J.L. Cummings, C.M. Herd, A.I. Bush, J. Alzheimers Dis., (2010), 20, 509-516

${ }^{91}$ A. Lakatos, É. Zsigó, D. Hollender, N.V. Nagy, L. Fülöp, D. Simon, Z. Bozsó, T. Kiss, Dalton Trans, (2010) 39, 1302

${ }^{92}$ A. Lakatos, B. Gyurcsik, N. V. Nagy, Z. Csendes, E. Wéber, L. Fülöp, T. Kiss, Dalton Trans, (2012) 41, 1713-1726

${ }^{93}$ V.B. Di Marco, A. Tapparo, G.G. Bombi, Ann Chim (Rome), (2001), 91, 595-603

${ }^{94}$ V.B. Di Marco, A. Tapparo, A. Dolmella, G.G. Bombi, Inorg Chim Acta, (2004), 157, 135-142

${ }^{95}$ A. K. Fink, R. R. German, M. Heron, S. L. Stewart, C. J. Johnson, J. L. Finch, D. Yin, P. E. Schaeffer, Cancer Epidemiol, (2012) 36, 22-28

${ }^{96}$ C. J. Johnson, H. K. Weir, A. K. Fink, R. R. German, J. L. Finch, R. K. Rycroft, D.Yin, Cancer Epidemiol, (2013) 37, 20-28

${ }^{97}$ R.J. Fram, Cisplatin and platinum analogues: recent advances, Curr Opin Oncol, (1992) 4, 1073-1079

${ }^{98}$ M. Rosenberg, L. VanCamp, T. Krigas, Nature, (1965) 205, 698-699

${ }^{99}$ C.A. Lepre, S.J. Lippard, F. Eckstein, Nucleic Acids and Molecular Biology, eds. D.M.J. Lilley, SpringerVerlag, Heidelberg (1990) 9-38

${ }^{100}$ N.P. Johnson, J.L. Butour, G. Villani, F.L. Wimmer, M. Defais, V. Pierson, V. Brabek, Metal antitumor compounds: the mechanism of action of platinum complexes, Springer-Verlag, Heidelberg (1989) 59-68

${ }^{101}$ C.X. Zhang, S.J. Lippard, Curr Opin Chem Biol, (2003) 7, 481-489

${ }^{102}$ K. Gyires, Zs. Fürst, Farmakológia, Farmakológia és farmakoterápia I., Medicina Könyvkiadó Zrt. Budapest, (2007)

${ }^{103}$ E. Wong, C. M. Giandomenico, Chem Rev, (1999) 99, 2451-2466

${ }^{104}$ F. Muggia, Gynecol Oncol, (2009) 112, 275-281

${ }^{105}$ P. Heffeter, U. Jungwirth, M.A. Jakupec, C.G. Hartinger, M. Galanski, L. Elbling, M. Micksche, B.K. Keppler, W. Berger, Drug Res Updates, (2008) 11, 1-16

${ }^{106}$ S.P. Fricker, Dalton Trans. (2007) 4903-4917

${ }^{107}$ P.C.A. Bruijnincx, P.J. Sadler, Curr Op Chem Biol, (2008) 12, 197-206

${ }^{108}$ C. R. Centerwall, K. A. Tacka, D. J. Kerwood, J. Goodisman, B. B. Toms, R. L. Dubowy, J. C. Dabrowiak, Mol Pharmacol, (2006) 70, 348-355

${ }^{109}$ U. M. Ohndorf, M. A. Rould, Q. He, C. O. Pabo, S. J. Lippard, Nature, (1999) 399, 708-712

${ }^{110}$ E. E. Brouwers, M. Tibben, H. Rosing, J. H. Schellens, J. H. Beijnen, Mass Spectrom Rev, (2008) 27, 67100

${ }^{111}$ W.F. Kean, L. Hart, W.W. Buchanan, Br J Rheumatol, (1997) 36, 560-572

${ }^{112}$ C.K. Mirabelli, R.K. Johnson, C. Sung, L.F. Faucette, K. Muirhead, S.T. Crooke, Cancer Res, (1985) 45, 32-39

${ }^{113}$ T.M. Simon, D.H. Kunishima, G.J. Vilbert, A. Lorbert, Cancer Res, (1981) 41, 94

${ }^{114}$ I. Ott, Coord Chem Rev, (2009) 253, 1670-1681

115 J. Málek, A. Watanabe, T. Mitsuhashi, Thermochim Acta, (1996) 282-283, 131-142 
${ }^{116}$ J.A. Lessa, G.L. Parrilha, H. Beraldo, Inorg Chim Acta, (2012) 393, 53-63

${ }^{117}$ A.V. Rudnev, L.S. Foteeva, C. Kowol, R. Berger, M.A. Jakupec, V.B. Arion, A.R. Timerbaev, B.K. Keppler, J Inorg Biochem, (2006) 100, 1819-1826

${ }^{118}$ L.R. Bernstein, T. Tanner, C. Godfrey, B. Noll, Metal-Based Drugs, (2000), 7, 33-47

${ }^{119}$ V.B. Arion, M.A. Jakupec, M. Galanski, P. Unfried, B.K. Keppler, J Inorg Biochem, (2002) 91, 298-305

${ }^{120}$ A. Dobrov, V.B. Arion, N. Kandler, W. Ginzinger, M.A. Jakupec, A. Rufińska, N. Graf von Keyserlingk, M. Galanski, C. Kowol, B.K. Keppler, Inorg Chem, (2006), 45, 1945-1950

${ }^{121}$ M.A. Jakupec, M. Galanski, V.B. Arion, C.G. Hartinger, B.K. Keppler, Dalton Trans, (2008) 183-194

${ }^{122}$ A.R. Timerbaev, Metallomics, (2009) 1, 193-198

${ }^{123}$ E. Alessio, G. Mestroni, A. Bergamo, G. Sava, Curr Top Med. Chem, (2004) 4, 1525-1535

${ }^{124}$ C. G. Hartinger, M. A. Jakupec, S. Zorbas-Seifried, M. Groessl, A. Egger, W. Berger, H. Zorbas, P. J. Dyson, B. K. Keppler, Chem Biodiversity, (2008) 5, 2140-2155

${ }^{125}$ C. G. Hartinger, S. Zorbas-Seifried, M.A. Jakupec, B. Kynast, H. Zorbas, B.K. Keppler, J Inorg Chem, (2006) 100, 891-904

${ }^{126}$ P. Heffeter, K. Böck, B. Atil, M.A.R. Hoda, W. Körner, C. Bartel, U. Jungwirth, B.K. Keppler, M. Micksche, W. Berger, G. Koellensperger, J Biol Inorg Chem, (2010) 15, 737-748

${ }^{127}$ G. Sava, F. Frausin, M. Cocchietto, F. Vita, E. Podda, P. Spessotto, A. Furlani, V. Scarcia, G. Zabucchi, Eur J Cancer, (2004) 40, 1383-1396

${ }^{128}$ F. Frausin, V. Scarcia, M. Cocchietto, A. Furlani, B. Serli, E. Alessio, G. Sava, J. Pharmacol Exp Ther, (2005) 313, 227-233

${ }^{129}$ S. Pacor, S. Zorzet, M. Cocchietto,M. Bacac, M. Vadori, C. Turrin, B. Gava, A. Castellarin, G. Sava, Pharmacol Exp Ther, (2004) 310, 737-744

${ }^{130}$ C.G. Hartinger, M.A. Jakupec, S. Zorbas-Seifried, M. Groessl, A. Egger, W. Berger, H. Zorbas, P.J. Dyson, B.K. Keppler, Chem Biodiversity, (2008) 5, 2140-2155

${ }^{131}$ S. Kapitza, M.A. Jakupec, M. Uhl, B.K. Keppler, B. Marian, Cancer Lett, (2005) 226, 115-121

${ }^{132}$ M.M. Kasprzak, L. Szmigiero, E. Zyner, J. Ochocki, J Inorg Biochem, (2011) 105, 518-524

${ }^{133}$ B. Therrien, Coord Chem Rev, (2009) 253, 493-519

${ }^{134}$ A. Habtemariam, M. Melchart, R. Fernandez, S. Parsons, I. D. H. Oswald, A. Parkin, F. P. A. Fabbiani, J. E. Davidson, A. Dawson, R. E. Aird, D. I. Jodrell, P. J Sadler, J Med Chem (2006) 49, 6858-6868

${ }^{135}$ R. E. Aird, J. Cummings, A. A. Ritchie, M. Muir, R. E. Morris, H. Chen, P. J. Sadler, D. I. Jodrell, Brit J. Cancer, (2002) 86, 1652-1657

${ }^{136}$ P. Buglyó, E. Farkas, Dalton Trans, (2009) 39, 8063-8070

${ }^{137}$ M. Melchart, A. Habtemariam, O. Novakova, S. A. Moggach, F. P. A. Fabbiani, S. Parsons, V. Brabec, P. J. Sadler, Inorg Chem, (2007) 46, 8950-8962

${ }^{138}$ P.C.A. Bruijnincx, P.J. Sadler, Adv Inorg Chem, (2009) 61, 1-51

${ }^{139}$ R. Fernandez, M. Melchart, A. Habtemariam, S. Parsons, P. J. Sadler, Chem. Eur J, (2004) 10, 5173-5179

${ }^{140}$ S. J. Dougan, M. Melchart, A. Habtemariam, S. Parsons, P. J. Sadler, Inorg Chem, (2006) 45, 1088210894

${ }^{141}$ K.S. Smalley, R. Contractor, N.K. Haass, A.N. Kulp, G.E. Atilla-Gokcumen, D.S. Williams, Cancer Res, 67, 2007, 209-217

${ }^{142}$ W.H. Ang, A. De Luca, C. Chapuis-Bernasconi, L. Juillerat-Jeanneret, M. Lo Bello, P.J. Dyson, ChemMedChem, (2007) 2, 1799-1806

${ }^{143}$ W. Kandioller, A. Kurzwernhart, M. Hanif, S.M. Meier, H. Henke, B.K. Keppler, C.G. Hartinger, J Organomet Chem, (2011) 696, 999-1010 
${ }^{144}$ W. Kandioller, C.G. Hartinger, A.A. Nazarov, C. Bartel, M. Skocic, M.A. Jakupec, V.B. Arion, B.K. Keppler, Chem Eur J, (2009) 15, 12283-12291

145 J. Kljun, A.K. Bytzek,W. Kandioller, C. Bartel, M.A. Jakupec, C.G. Hartinger, B.K. Keppler, I. Turel, Organometallics, (2011) 30, 2506-2512

${ }^{146}$ N. Gligorijević, S. Aranđelović, L. Filipović, K. Jakovljević, R. Janković, S. Grgurić-Šipka, I. Ivanović, S. Radulović, Ž. Lj. Tešić, J Inorg Biochem, (2012) 108, 53-61

${ }^{147}$ W.H. Ang, A. Casini, G. Sava, P.J. Dyson, J Organomet Chem, (2011) 696, 989-998

148 A.M. Pizarro, M. Melchart, A. Habtemariam, L. Salassa, F.P.A. Fabbiani, S. Parsons, P.J. Sadler, Inorg Chem, (2010) 49, 3310-3319

${ }^{149}$ F. Wang, H. Chen, S. Parsons, I.D.H. Oswald, J.E. Davidson, P.J. Sadler, Chem Eur J, (2003) 9, 58105820

${ }^{150}$ F. Beckford, J. Thessing, J. Woods, J. Didion, N. Gerasimchuk, A. Gonzalez-Sarrias, N.P. Seeram, Metallomics, (2011) 3, 491-502

${ }^{151}$ T. Kiss, T. Jakusch, D. Hollender, É. A. Enyedy, L. Horváth, J Inorg Biochem, (2009) 103, 527-535

${ }^{152}$ S. Grgurić-Šipka, I. Ivanović, G. Rakić, N. Todorović, N. Gligorijević, S. Radulović, V.B. Arion, B.K. Keppler, Ž. Lj. Tešić, Eur J Med Chem, (2010) 45, 1051-1058

${ }^{153}$ I. Ivanović, S. Grgurić-Šipka, N. Gligorijević, S. Radulović, A. Roller, Ž. L. Tešić, B. K. Keppler, J Serb Chem Soc, (2011) 76, 53-61

${ }^{154}$ W. Kandioller, C.G. Hartinger, A.A. Nazarov, M.L. Kuznetsov, R.O. John, C. Bartel, M.A. Jakupec, V.B. Arion, B.K. Keppler, Organometallics, (2009) 28, 4249-4251

155 C.L. Stoner, M.D. Troutman, C.E. Laverty, Nat Rev Drug Discovery, (2008) 131-153

156 A. Boobis, U. Gundert-Remy, P. Kremers, P. Macheras, O. Pelkonen, Eur J Pharm Sci, (2002) 17, 183193

157 T. Kiss, T. Jakusch, D. Hollender, Á. Dörnyei, É.A. Enyedy, J. Costa Pessoa, H. Sakurai, A. Sanz-Medel, Biospeciation of antidiabetic VO(IV) complexes, Coord Chem Rev, (2008) 252, 1153-1162

158 J.B. Vincent, S. Love, Biochim Biophys Acta, (2012) 1820, 362-78

${ }^{159}$ A.R. Timerbaev, C.G. Hartinger, S.S. Aleksenko, B.K. Keppler, Chem. Rev, (2006) 106, 2224-2248

${ }^{160}$ W.H. Ang, P.J. Dyson, Eur J Inorg Chem, (2006), 4003-4018

${ }^{161}$ T. Peters, All About Albumin: Biochemistry, Genetics and Medical Applications, Academic Press, San Diego, (1996)

162 G. Griffiths, L. Sweeney Clinical trials in oncology, Medicine, (2012) 40, 20-23

${ }^{163}$ Z. D. Liu, H. H. Khodr, D. Y. Liu, S. L. Lu, R. C. Hider, J Med Chem, (1999) 42 4814-4823

${ }^{164}$ V. Monga, K. H. Thompson, V. G. Yuen, V. Sharma, B. O. Patrick, J. H. McNeill, C. Orvig, Inorg Chem, (2005) 44, 2678-2688.

${ }^{165}$ P. Gans, A. Sabatini, A. Vacca, Talanta, (1996) 43, 1739-1753

${ }^{166}$ L. Bíró, E. Farkas, P. Buglyó, Dalton Trans, (2012) 41, 285-291

${ }^{167}$ N.D. Chasteen, J.K. Grady, C.E. Holloway, Inorg. Chem., 25, 1986, 2754-2760

${ }^{168}$ G. Gran, ActaChem Scand, (1950) 4, 559-577

${ }^{169}$ H.M. Irving, M.G. Miles, L.D. Petit, Anal Chim Acta, (1967) 38, 475-482

${ }^{170}$ L. Zékány, I. Nagypál, in: Computational Methods for the Determination of Stability Constants (Ed.: D. L. Leggett), Plenum Press, New York, (1985) 291-353

${ }^{171}$ I. Kovács, J. Szőke, Molekulaspektroszkópia, Akadémiai Kiadó, Budapest (1987)

${ }^{172}$ A. Rockenbauer, P. Simon, J Magn Reson, (1975) 18, 320-325

${ }^{173}$ A. Rockenbauer, T. Szabó-Plánka, Zs. Árkosi, L. Korecz, J Am Chem Soc, (2001)123, 995-1003 
${ }^{174}$ A. Rockenbauer, L. Korecz, Appl Magn Reson, 10 (1996) 29-43

${ }^{175}$ J.R. Lakowicz, Principles of Fluorescence Spectroscopy, Plenum Press, New York, (1983)

${ }^{176}$ É.A. Enyedy, E. Farkas, O. Dömötör, M.A. Santos, J Inorg Biochem, (2011) 105, 444-453

${ }^{177}$ H. Kurz, in: M.M. Reidenberg, Drug Protein Binding, Praeger, Publishers eds. S. ErillNew York, (1986) 70-92

${ }^{178}$ É.A. Enyedy, A. Lakatos, L. Horváth, T. Kiss, J Inorg Biochem, (2008) 102, 1473-1485

${ }^{179}$ É.A. Enyedy, O. Dömötör, E. Varga, T. Kiss, R. Trondl, C.G. Hartinger, B.K. Keppler, J Inorg Biochem, (2012) 117, 189-197

${ }^{180}$ R. Petrola, Ann. Acad. Sci. Fennicae, (1987), 215

${ }^{181}$ L. Bíró, E. Farkas, P. Buglyó, Dalton Trans, (2010) 42, 10272-10278

${ }^{182}$ V.B. Di Marco, R.A. Yokel, M.G. Ferlin, A. Tapparo, G.G. Bombi, Eur J Inorg Chem, (2002) 10, 2648 2655

${ }^{183}$ V.B. Di Marco, R.A. Yokel, H. Li, A. Tapparo, G.G. Bombi, Inorg Chim Acta, (2004) 357, 3753-3758

${ }^{184}$ A. Dean, M.G. Ferlin, P. Brun, I. Castagliuolo, D. Badocco, P. Pastore, A. Venzo, G.G. Bombi, V.B. Di Marco, Dalton Trans, (2008) 1689-1697

185 A. Dean, M.G. Ferlin, P. Brun, I. Castagliuolo, R.A.Yokel, D. Badocco, P. Pastore, A. Venzo, G.G. Bombi, V.B. Di Marco, Dalton Trans, (2009) 1815-1824

${ }^{186}$ V.B. Di Marco, A. Dean, M.G. Ferlin, R.A. Yokel, H. Li, A. Venzo, G.G. Bombi, Eur J Inorg Chem, (2006) 1284-1293

${ }^{187}$ A. Dean, É. Sija, É. Zsigó, M.G. Ferlin, D. Marton, V. Gandin, C. Marzano, D. Badocco, P. Pastore, A. Venzo, R. Bertani, T. Kiss, V. Di Marco, Eur J Inorg Chem, (2013) 2013, 1310-1319

${ }^{188}$ A. Dean, M.G. Ferlin, P. Brun, I. Castagliuolo, R.A. Yokel, A. Venzo, G.G. Bombi, V.B. Di Marco Inorg Chim Acta, (2011) 373, 179-186

${ }^{189}$ C.G. Skoutelis, D. Vlastos, M.C. Kortsinidou, I.T. Theodoridis, M.I. Papadaki, J Hazard Mater, (2011) 197, 137-143

${ }^{190}$ A.R. Katritzky, J.M. Lagowski, The principles of heterocyclic chemistry. Academic Press, New York, (1968)

${ }^{191}$ G. Crisponi, A. Dean, V. Di Marco, J.I. Lachowicz, V.M. Nurchi, M. Remelli, A. Tapparo, Anal Bioanal Chem, (2013) 405, 585-601

${ }^{192}$ P. Faller, C. Hureau, Dalton Trans, (2009) 1080-1094

${ }^{193}$ Y.H. Hung, A.I. Bush, R.A. Cherny, J Biol Inorg Chem, (2010) 15, 61-76

${ }^{194}$ E.T. Clarke, A.E. Martell, Inorg Chim Acta (1992) 191, 57-63

${ }^{195}$ A. Dean, V.B. Di Marco, elökészületben

196 E.A. Enyedy, G.M. Bognar, T. Kiss, M. Hanif, C.G. Hartinger, J Organomet Chem, in press, DOI:10.1016/j.jorganchem.2012.10.042

${ }^{197}$ M. Hanif, H. Henke, S. M. Meier, S. Martic, M. Labib, W. Kandioller, M. A. Jakupec, V. B. Arion, H.-B. Kraatz, B. K. Keppler, C. G. Hartinger, Inorg. Chem., Vol. 49(17), (2010), pp. 7953-7963

${ }^{198}$ T. Jakusch, K. Gajda-Schrantz, Y. Adachi, H. Sakurai, T. Kiss, L. Horváth, J Inorg Biochem, (2006) 100, 1521-1526

${ }^{199}$ Z. Vargová, V. Zeleòák, I.C'1saøová, K. Györyová, Thermochim Acta, (2004) 423, 149-157

${ }^{200}$ O.Z. Yeşilel, İ. İlker, M.S. Refat, H.i Ishida, Polyhedron, (2010) 29, 2345-2351

${ }^{201}$ T. Jakusch, W. Jin, L. Yang, T. Kiss, D. C. Crans, J Inorg Biochem, (2003) 95, 1-13

${ }^{202}$ T. K. Prasad, M.V. Rajasekharan, Polyhedron, (2007) 26, 1364-1372 
203 A. C. Gonzalez-Baró, E. E. Castellano, O. E. Piro, Beatriz S. Parajón-Costa, Polyhedron, (2005) 24, 4955

${ }^{204}$ B. S. Parajón-Costa, O E. Piro, R Pis-Diez, E E. Castellano, A C. González-Baró, Polyhedron, (2006) 25, 2920-2928

${ }^{205}$ T. S. Kamatchi, N. Chitrapriya, H. Lee, C. F. Fronczek, F. R. Fronczek, K. Natarajan, Dalton Trans, (2012) 41, 2066-2077

${ }^{206}$ T. Stringer, B. Therrien, D.T. Hendricks, H. Guzgay, G.S. Smith, Inorg Chem Commun, (2011) 14, 956960

${ }^{207}$ G, Gasser, I, Ott, N, Metzler-Noltem, J Med Chem. (2011) 54, 3-25

${ }^{208}$ É. A. Enyedy, L. Horváth, A. Hetényi, T. Tuccinardi, C. G. Hartinger, B. K. Keppler, T. Kiss, Bioorg Med Chem, (2011) 19, 4202-4210

${ }^{209}$ S, Bi, D, Song, Y, Tian, X, Zhou, Z, Liu, H, Zhang, Spectrochim Acta A, (2005) 61, 629-636

${ }^{210}$ Y. Chengnong, T. Jinqiang, X. Dan, L. Yi, P. Zuting, Chin JAnal Chem, (2006) 34, 796-800

${ }^{211}$ B. Ahmad, S. Parveen, R.H. Khan, Biomacromolecules, (2006) 7, 1350-1356

${ }^{212}$ S. Bi, L. Ding, Y. Tian, D. Song, X. Zhou, X. Liu, H. Zhang, J Mol Struct, (2004) 703, 37-45 


\section{Köszönetnyilvánítás}

Elsőként szeretnék köszönetet mondani témavezetőmnek Dr. Kiss Tamásnak, aki lehetővé tette, hogy Ph.D. tanulmányaimat az ö témavezetése mellett végezhessem. Szakmai tudása és embersége példaértékű számomra. Köszönöm, hogy az első perctől bízott bennem, és bizalma töretlen maradt a négy év alatt.

Köszönettel tartozom Dr. Enyedy Éva Annának témavezetői segítségéért és hasznos tanácsaiért.

Köszönetemet szeretném kifejezni Dr. Jakusch Tamásnak, aki bár mindig nagyon elfoglalt, szakmai problémáimmal mégis bármikor fordulhattam hozzá segítségért.

Köszönet illeti Dr. Valerio Di Marco-t, aki padovai tanulmányaim alatt koordinálta munkámat, és Dr. Nagy Nóra Veronikát, az MTA-TTIK Molekuláris Farmakológiai Intézet munkatársát, az ESR mérések és kiértékelések során nyújtott segítségéért.

Köszönöm Dr. Peintler Gábor segítségét, aki idejét nem sajnálva szakmai tanácsaival támogatta munkámat.

Köszönöm a TÁMOP 4.2.4.A/2-11-1-2012-0001 Nemzeti Kiválóság Program támogatását, mely Jedlik Ányos Doktorjelölt Ösztöndíjjal támogatott.

Köszönetemet szeretném kifejezni barátaimnak, akik megszínesítették az elmúlt évek mindennapjait, és kedves kollégáimnak - különösképpen Szücsné Tóth Katalin vegyésztechnikusnak, Árus Dávidnak, Matyuska Ferencnek és Dömötör Orsolyának.

A legnagyobb köszönettel pedig családomnak tartozom, akik végig kísértek, szeretetükkel és önfeláldozásukkal támogattak azon az úton, amin eljutottam idáig. 